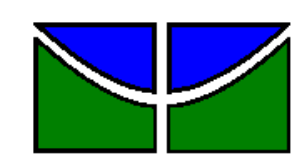

UNIVERSIDADE DE BRASÍLIA

FACULDADE DE ECONOMIA, ADMINISTRAÇÃO E CONTABILIDADE PROGRAMA DE PÓS-GRADUAÇÃO EM ADMINISTRAÇÃO DOUTORADO EM ADMINISTRAÇÃO

A INFLUÊNCIA DOS VALORES E DA IDADE NO JULGAMENTO E SIGNIFICADO DE AUTOMÓVEIS: UM ESTUDO COMPARATIVO ENTRE BRASIL E ESTADOS UNIDOS DA AMÉRICA

BRENO GIOVANNI ADAID CASTRO

BRASÍLIA, DF 
BRENO GIOVANNI ADAID CASTRO

\title{
A INFLUÊNCIA DOS VALORES E DA IDADE NO JULGAMENTO E SIGNIFICADO DE AUTOMÓVEIS: UM ESTUDO COMPARATIVO ENTRE BRASIL E ESTADOS UNIDOS DA AMÉRICA
}

\author{
Tese de doutorado apresentada ao \\ Programa de Pós-Graduação em \\ Administração como requisito parcial \\ para a obtenção do título de doutor em \\ administração.
}

Orientador: Prof. Dr. Cláudio Vaz Torres 
BRENO GIOVANNI ADAID CASTRO

\section{A INFLUÊNCIA DOS VALORES E DA IDADE NO JULGAMENTO E SIGNIFICADO DE AUTOMÓVEIS: UM ESTUDO COMPARATIVO ENTRE BRASIL E ESTADOS UNIDOS DA AMÉRICA}

Apresentada e aprovada publicamente em 12 de dezembro de 2014 por:

Prof. Dr. Cláudio Vaz Torres - Orientador

Programa de Pós-graduação em Administração

Programa de Pós-graduação em Psicologia Social, do Trabalho e das Organizações Universidade de Brasília, Brasil

Profa. Dra. Eda Castro Lucas de Souza - Membro Interno

Programa de Pós-graduação em Administração

Universidade de Brasília, Brasil

Prof. Dr. Cid Gonçalves Filho - Membro Externo

Programa de Pós-graduação em Administração

Universidade FUMEC, Brasil

Profa. Dra. Denise Del Prá Netto Machado - Membro Externo

Programa de Pós-graduação em Administração

Universidade Regional de Blumenau, Brasil

Profa. Dra. Maria Luisa Mendes Teixeira - Membro Externo

Programa de Pós-graduação em Administração

Universidade Mackenzie, Brasil

Profa. Dra. Raquel Carvalho Hoersting - Suplente

Programa de Pós-graduação em Psicologia Social, do Trabalho e das Organizações

Universidade de Brasília, Brasil 


\section{Agradecimentos}

Agradeço primeiramente à minha mãe, que sempre foi mãe e pai durante uma vida inteira de dedicação incondicional à família sendo a alma mais iluminada que existe nesse mundo.

À Tatiana que sempre me apoiou e me estimulou a sonhar mais alto, sempre acreditou no meu potencial profissional e pessoal, não fosse ela eu nunca teria chegado até aqui, é a maior responsável por essa conquista. Não sei o que é maior, meu carinho, meu amor ou minha admiração por você.

Agradeço ao meu orientador, Cláudio, por ter sido incrivelmente fantástico em todo o processo, não só com as sábias palavras de conhecimento no desenvolver do conteúdo da tese mas nos conselhos pessoais e profissionais que se mostraram certíssimos e extremamente valiosos ao longo do tempo, nunca encontrei uma pessoa que eu admirasse tanto.

Agradeço à minha família, que sempre esteve do meu lado, meus irmãos Adaid, Rodrigo e Cláudia que sempre me apoiaram e estimularam a desenvolver esse trabalho.

Agradeço ao seu Humberto e a Dona Bel não só pelo apoio mas pelo exemplo de pessoas que são, sem dúvida alguma seu exemplo de vida é inspirador no sentido de luta, proteção e sabedoria.

Aos meus amigos de estudos do doutorado, que durante todos esses 4 anos lutaram cada batalha e sofreram comigo disciplina a disciplina. Essa tese não seria possível sem a ajuda do Thiago Gomes, que participou desde sua concepção até a revisão final. Sueli Menelau que participou com diversos preciosos comentários que direcionaram a tese e Thiago Carneiro e Eduardo de São Paulo que durante todo o processo estiveram juntos divindo conhecimentos e esforços que auxiliaram na realização da tese.

Agradeço também aos meus amigos de Belo Horizonte, Bernardo, Paulo, Francisco e Rafael e aos amigos de Brasília, Marcus e Rodrigo Maués que sempre estiveram perto, participando de minha vida e tornando esse trabalho mais leve, seja contribuindo ou seja fazendo o que fazem de melhor que é serem amigos.

Por fim ao Dr. Kahle que me recebeu de forma tão calorosa na University Of Oregon e conferiu preciosos conselhos para o meu trabalho.

Agradeço à Coordenação de Aperfeiçoamento de Pessoal de Nível Superior (CAPES/Brasil)pois este trabalho foi realizado através de concessão de bolsa sanduiche. 


\section{Resumo}

Este estudo teve por finalidade identificar a influência da idade nos Valores, Tipos de Julgamento e Atribuição de Significado no Brasil e nos Estados Unidos da América para a compra de automóveis devido à escassez de estudos transculturais sobre o tema. Para atender a esse propósito, 565 respondentes no Brasil e 450 nos Estados Unidos da América preencheram um questionário com 3 escalas, escala LOV (List of Values) (KAHLE; KENNEDY, 1988), escala de Julgamento e Significado (ALLEN, 1997, 2000) e o Portraits Values Questionnaire Revised (PVQ-R) (Schwartz et al. 2012). Os resultados indicam que a idade guarda pouca relação com Valores, Julgamento e Significado no Brasil e não possui relação nos Estados Unidos da América. Foi verificado que o tipo de julgamento predominante para avaliação de automóveis no Brasil é afetivo enquanto nos Estados Unidos da América é passo a passo. Foi proposto um modelo de influência dos Valores nos Tipos de Julgamento e Atribuição de Significado para a compra de automóveis, em ambos os países, e verificou-se que os Valores Humanos são capazes de predizer melhor o tipo de Julgamento e Atribuição de Significado do que os Valores Pessoais. Por fim, as limitações da pesquisa e a agenda de pesquisa foram apresentadas.

Palavras-chave: Valores, Idade, Automóveis, Significado e Julgamento 


\begin{abstract}
The main purpose of this research was to verify the influence of the age on the Values, Judgment and Meaning in Brazil and the United States of America for automobile evaluation due to the lack of scientific research in cross-cultural studies. To achieve this objective 565 individuals in Brazil and 450 in the United States of America filled a questionnaire containing 3 scales, LOV Scale (List of Values) (KAHLE; KENNEDY, 1988), the Judgment and Meaning Scale (ALLEN, 1997, 2000)and thePortraits Values Questionnaire Revised (PVQ-R)(Schwartz et al. 2012). The results suggests that age is low related with Values, Judgment and Meaning in Brazil and has no relation with the same variables in the United States of America. The Piecemeal Judgment was predominant in the United States of America for automobile evaluation while in Brazil the Affective Judgment was predominant. A model was developed to relate the influence of the Values on the types of judgment and meaning and it was verified that Human Values can predictbetter the type of judgment and meaning than Personal Values. The limitations of the research and the research agenda for it is presented in the last chapter.
\end{abstract}

Keywords: Values, Age, Automobile, Judgment and Meaning 


\section{Sumário}

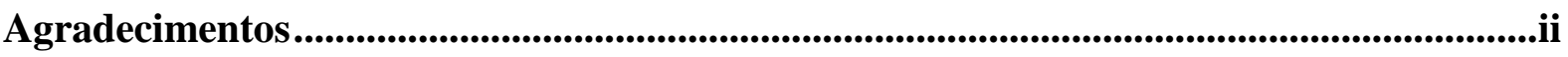

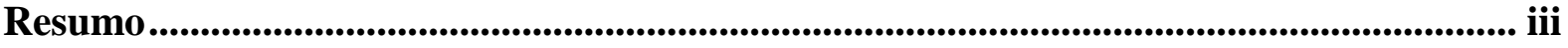

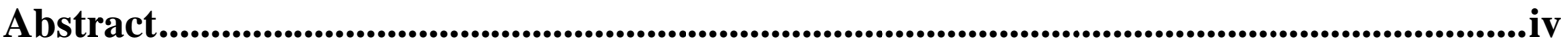

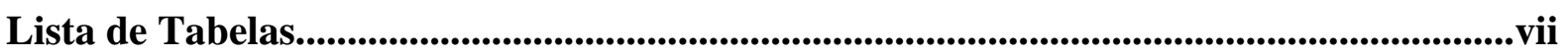

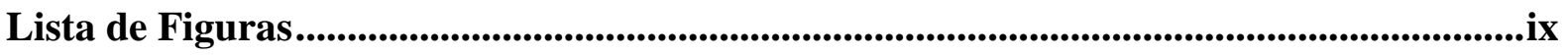

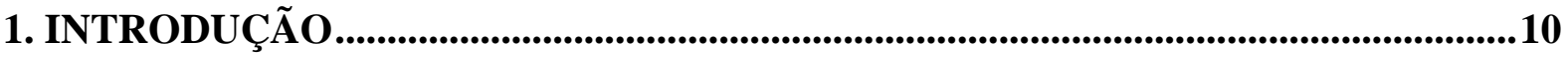

1.1 Contextualização e Justificativa.....................................................................11

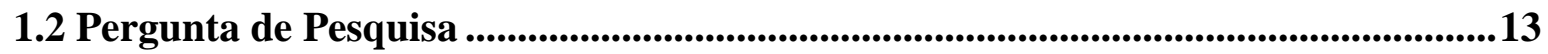

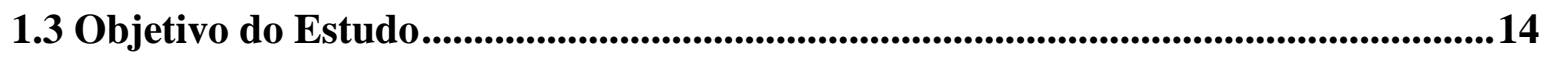

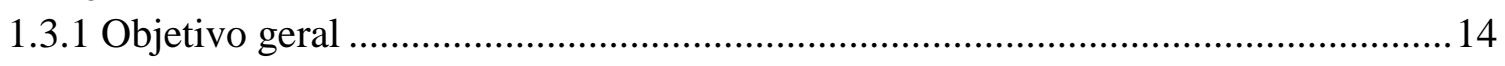

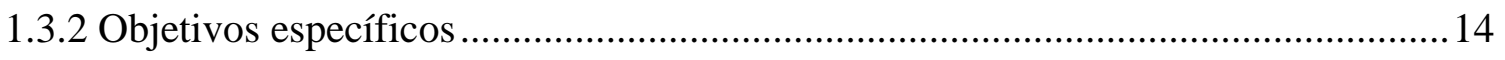

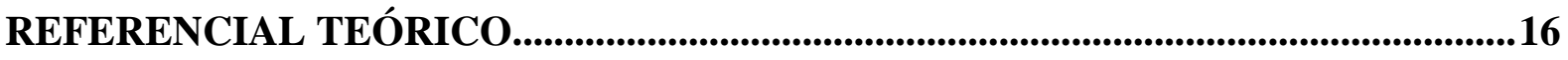

2. O Comportamento do Consumidor...............................................................................................16

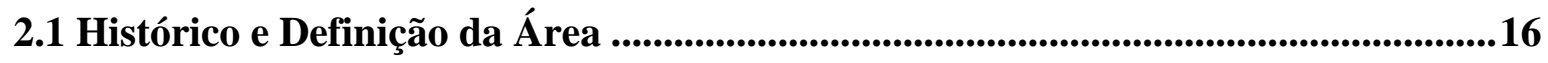

2.2 Segmentação .........................................................................................................................................20

2.3 Segmentação comportamental .............................................................................................23

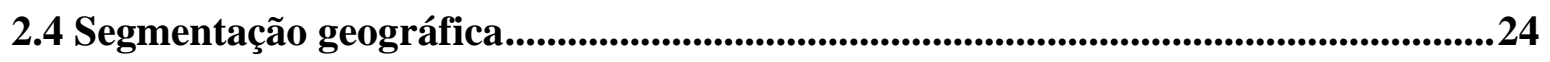

2.5 Segmentação demográfica ..........................................................................................................225

2.6 Segmentação psicológica e estilo de vida.........................................................26

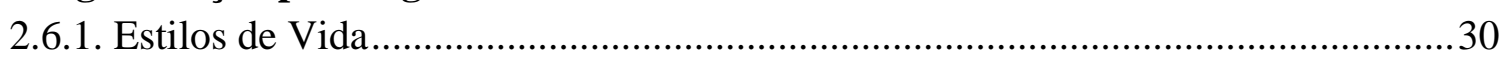

2.6.2. Atividades, interesses e opiniões ........................................................................ 31

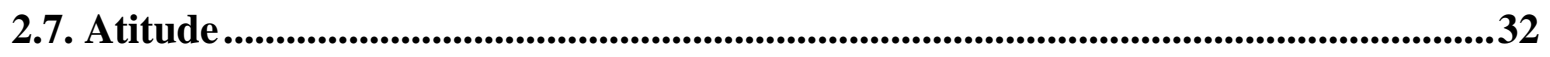

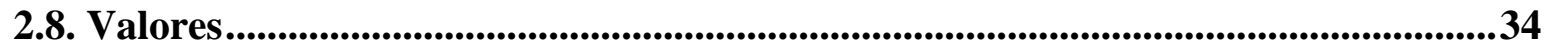

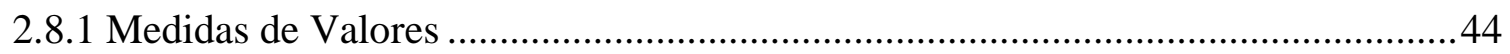

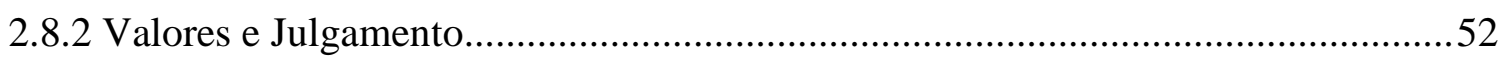

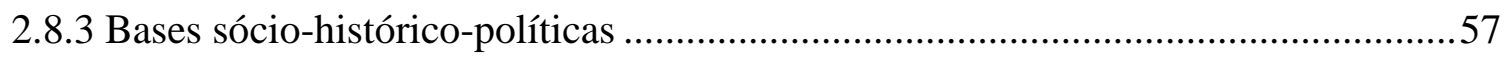

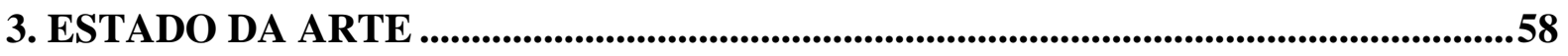

3.1 Introduçãão..................................................................................................................................58

3.2 Pesquisa Bibliométrica: O Método Empregado .......................................................559

3.3 Estudo 1 - Análise bibliométrica em comportamento do consumidor ...................61

3.3.1 Descrição e análise dos resultados bibliométricos ..................................................61

3.3.2 Institucionalização da Pesquisa sobre Comportamento do Consumidor no Brasil .67

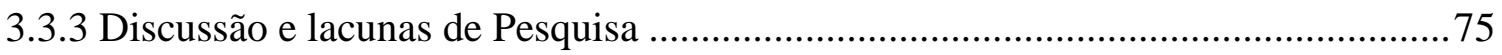

3.3.4 Conclusões, Contribuições e Limitações do Estudo I .............................................78

3.4 Estudo II - Preferência e Consumo de Automóveis no Brasil e no Mundo..............79

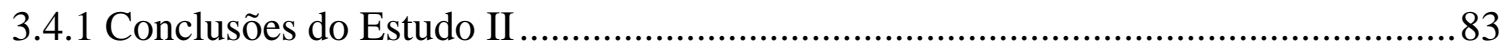




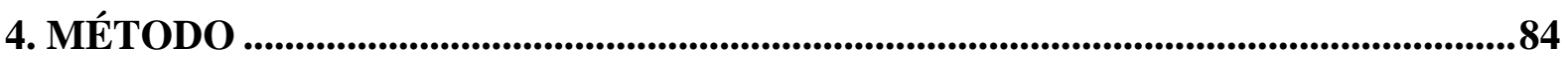

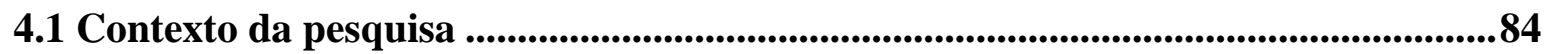

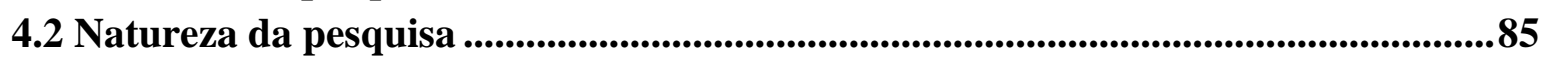

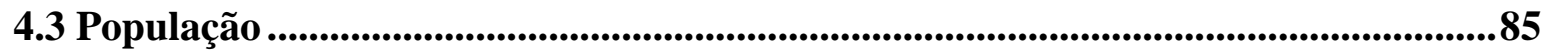

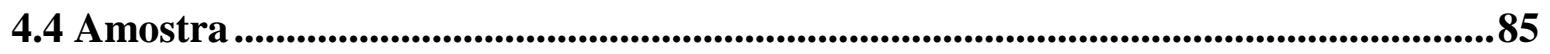

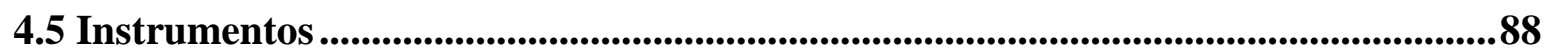

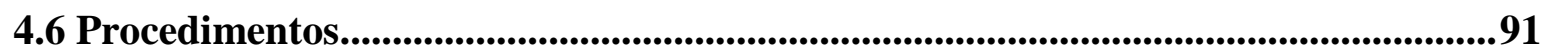

4.7 Modelo Geral de Pesquisa .................................................................................94

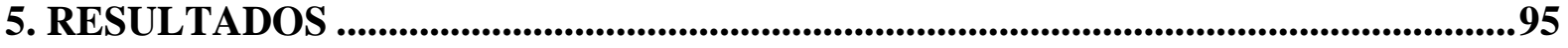

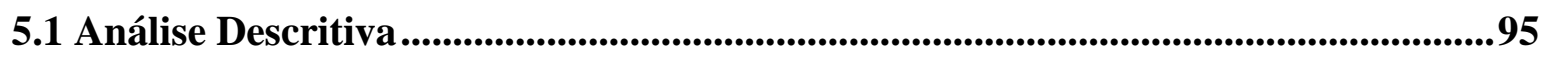

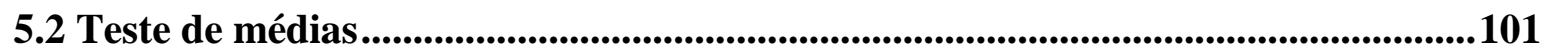

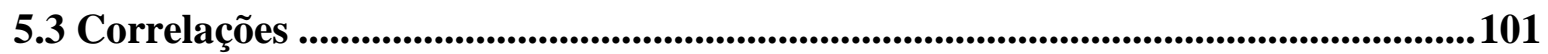

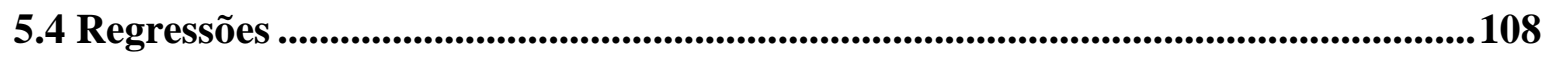

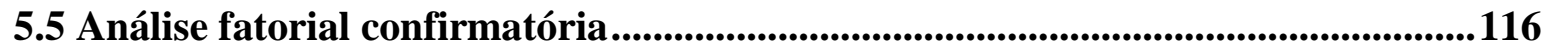

5.5.1 Análise confirmatória dos tipos de julgamento e atribuição de significado ...........117

5.5.2 Análise confirmatória dos Valores Humanos do modelo .................................... 122

5.6 Mensuração dos modelos gerais............................................................................................ 125

5.7 Modelo Estrutural ........................................................................................................ 129

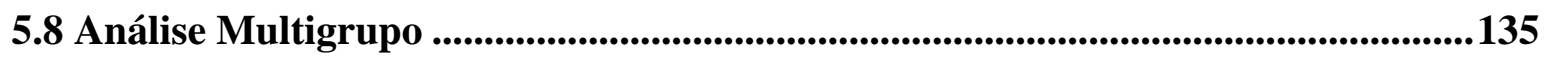

6. DISCUSSÃO............................................................................ Error! Bookmark not defined.

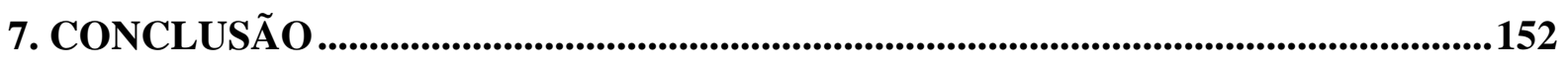

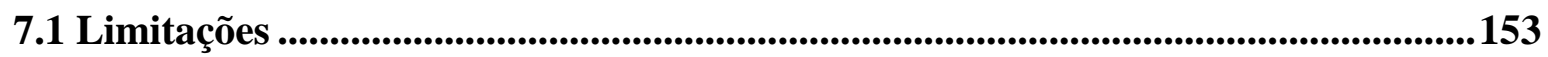

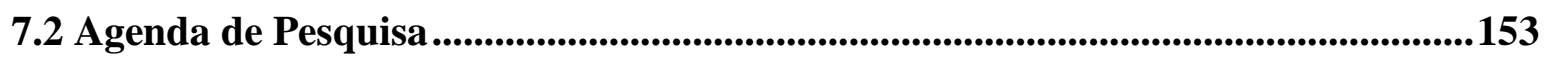

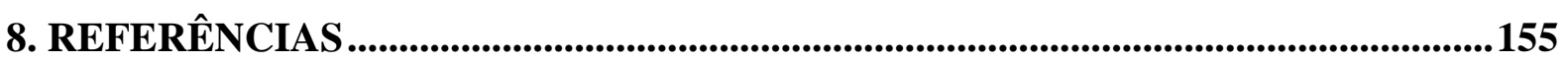

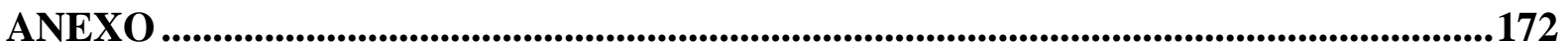




\section{Lista de Tabelas}

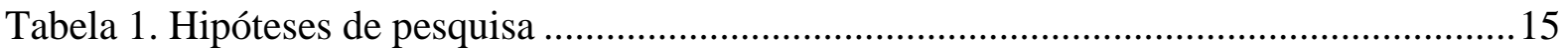

Tabela 2. Evolução da escola de comportamento do consumidor .......................................... 17

Tabela 3. Enfrentamentos de uma sociedade e suas respostas.................................................36

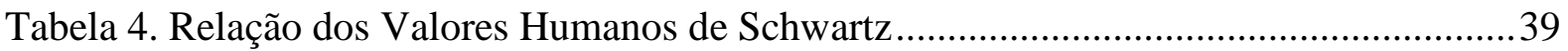

Tabela 5. Definição conceitual dos 10 tipos motivacionais de acordo com seus objetivos e

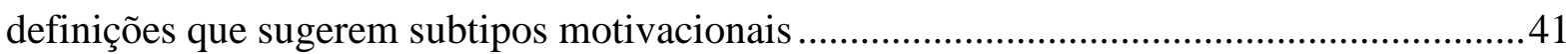

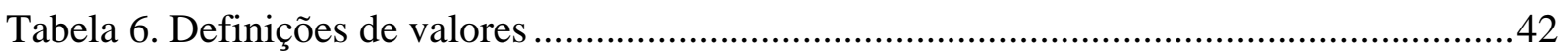

Tabela 7. Relação dos Valores Humanos de Rokeach................................................................ 45

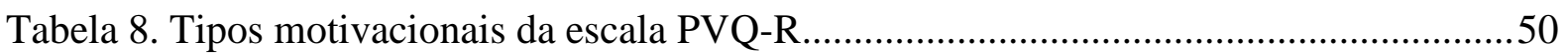

Tabela 9. Os 19 Valores da Teoria Refinada, definidos em termos de Metas Motivacionais .50

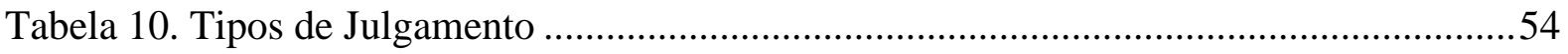

Tabela 11. Lista de Periódicos de Administração Analisados .................................................61

Tabela 12. Grupos de pesquisa sobre comportamento do consumidor .....................................68

Tabela 13. Grupos de pesquisa, de acordo com a grande área de concentração......................71

Tabela 14. Discriminação dos grupos de pesquisa de acordo as áreas do grupo......................72

Tabela 15. Grupos de pesquisa da base atual, na área administração, por status de atualização

Tabela 16. Tamanho de amostras para efeitos pequenos, médios e grandes com poder

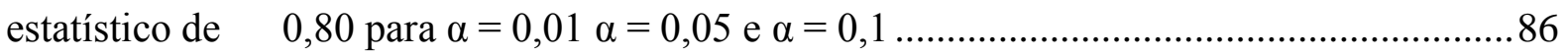

Tabela 17. Tipos motivacionais dos Valores Humanos no Brasil ......................................... 89

Tabela 18. Tipos de Julgamento e Atribuição de Significado ................................................90

Tabela 19. Descrição das siglas dos construtos e variáveis utilizadas.....................................96

Tabela 20. Estatística descritiva dos dados coletados no Brasil ............................................98

Tabela 21. Estatística descritiva dos dados coletados nos Estados Unidos da América........ 100

Tabela 22. Testes-T para os tipos de julgamento comparando Brasil e Estados Unidos da

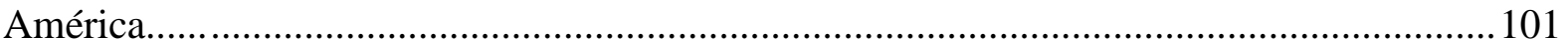

Tabela 23. Correlações entre valores pessoais, idade, atributos tangíveis do carro, significado

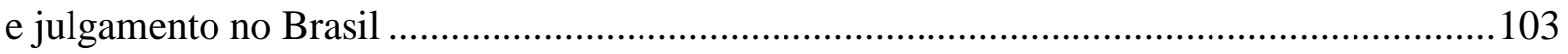

Tabela 24. Correlações entre valores pessoais, idade, atributos tangíveis do carro, significado

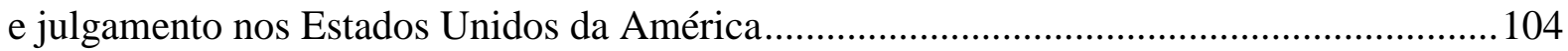

Tabela 25. Correlações entre Valores Humanos, Significado e Julgamento e Idade no

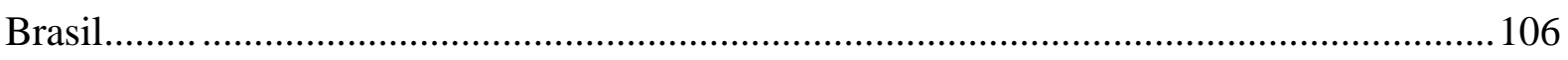

Tabela 26. Correlações entre Valores Humanos, Significado e Julgamento e Idade nos Estados Unidos da América ............................................................................................ 107

Tabela 27. Regressões que utilizam Valores Pessoais e Valores Humanos no Brasil............109

Tabela 28. Regressões utilizando Valores Pessoais e Valores Humanos nos Estados Unidos

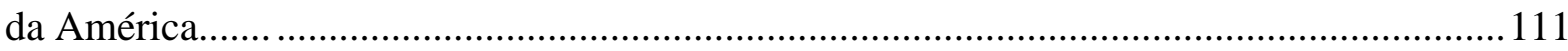

Tabela 29. Regressão stepwise para Julgamento afetivo predito por Valores Humanos no

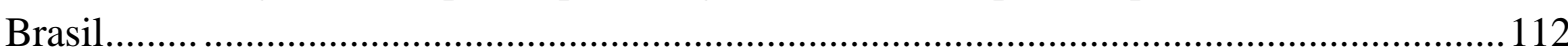


Tabela 30. Regressão stepwise para Julgamento Passo a Passo predito por Valores Humanos no Brasil.....

Tabela 31. Regressão stepwise para Significado Simbólico predito por Valores Humanos no Brasil.

Tabela 32. Regressão stepwise para Significado Utilitário predito por Valores Humanos no Brasil.

Tabela 33. Regressão stepwise para atributos tangíveis do carro predito por Valores Humanos no Brasil

Tabela 34. Regressão stepwise para Julgamento afetivo predito por Valores Humanos nos Estados Unidos da América

Tabela 35. Regressão stepwise para Julgamento Passo a Passo predito por Valores Humanos e idade nos Estados Unidos da América

Tabela 36. Regressão stepwise para Significado Simbólico predito por Valores Humanos e idade nos Estados Unidos da América.

Tabela 37. Regressão stepwise para Significado Utilitário predito por Valores Humanos e idade nos Estados Unidos da América.

Tabela 38. Regressão stepwise para atributos tangíveis do carro predito por Valores Humanos nos Estados Unidos da América

Tabela 39. Indices de estimação do modelo teórico da escala de Significado e Julgamento em seus respectivos fatores no Brasil

Tabela 40. Estimativas da análise fatorial confirmatória da escala de Significado e Julgamento nos Estados Unidos da América

Tabela 41. Validade convergente e discriminante dos fatores da escala de Julgamento e Significado no Brasil

Tabela 42. Validade convergente e discriminante dos fatores da escala de Julgamento e Significado nos Estados Unidos da América.

Tabela 43. Estimativas da análise fatorial confirmatória dos Valores Humanos aplicado no modelo geral no Brasil

Tabela 44. Validade convergente e discriminante dos fatores da Valores Humanos presentes no modelo no Brasil

Tabela 45. Estimativas da análise fatorial confirmatória dos Valores Humanos aplicado no modelo geral nos Estados Unidos da América

Tabela 46. Validade convergente e discriminante dos fatores da Valores Humanos presentes no modelo no Brasil

Tabela 47. Estimativas do Modelo Geral de consumo de veículos automotores no Brasil e tipo de julgamento e atribuição de significado

Tabela 48. Estimativas do Modelo Geral de consumo de veículos automotores nos Estados Unidos da América e tipo de julgamento e atribuição de significado .................................... 128

Tabela 49. Estimativas do Modelo Estrutural no Brasil ..................................................... 129

Tabela 50. Estimativas do Modelo Estrutural nos Estados Unidos da América..................... 133

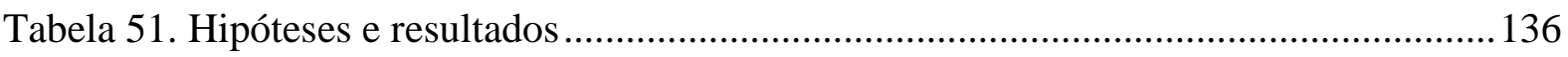




\section{Lista de Figuras}

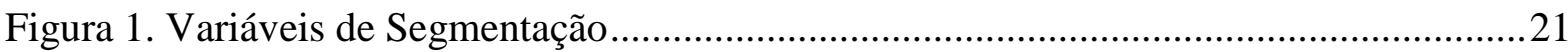

Figura 2. Origens e influências da segmentação psicológica .................................................28

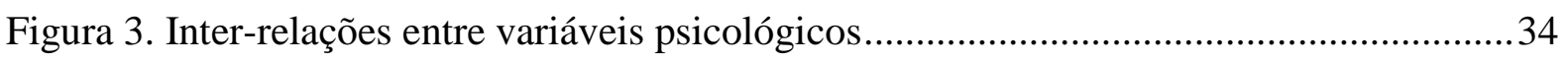

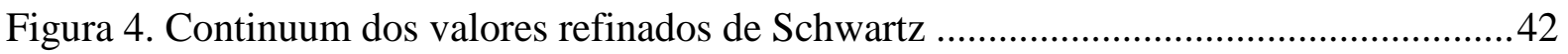

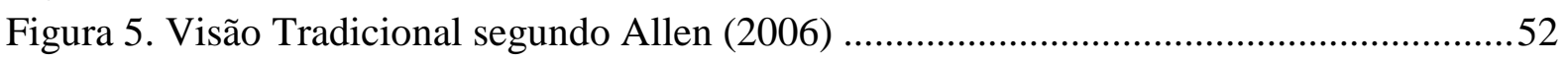

Figura 6. Representação conceitual do modelo de duas rotas ................................................55

Figura 7. Artigos relacionados a comportamento do consumidor publicados por ano............63

Figura 8. Universidades com maior número de autores ........................................................64

Figura 9. Instrumentos utilizados exclusivamente ou em associação .....................................65

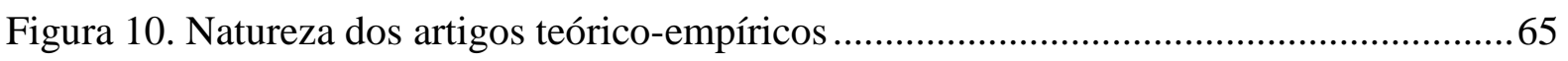

Figura 11. Técnicas de análise utilizadas nos artigos de Valores Organizacionais .................66

Figura 12. Assuntos mais estudados entre as pesquisas de Comportamento do Consumidor.67

Figura 13. Evolução dos grupos de pesquisa de 2000 a 2010 ................................................73

Figura 14. Evolução das Linhas de Pesquisa nos Censos de 2000 a 2010 ...............................74

Figura 15. Evolução da Produção C,T\&A nos Censos de 2000 a 2010 .................................... 74

Figura 16. Modelo Geral de Pesquisa .................................................................................. 94

Figura 17. Estimativa da AFC da Escala de Significado e Julgamento no Brasil .................118

Figura 18. Modelo Estrutural Geral ...................................................................................... 131

Figura 19. Relação de Mediação de atributos tangíveis do carro entre Segurança Pessoal e

Julgamento Passo a Passo no Brasil................................................................................... 132

Figura 20. Modelo estrutural nos Estados Unidos da América ........................................... 134

Figura 21. Relação de Mediação de atributos tangíveis do carro entre Segurança Pessoal e

Julgamento Passo a Passo nos Estados Unidos da América ................................................ 135 


\section{INTRODUÇÃO}

O estudo do comportamento do consumidor consiste em uma parte essencial do marketing; a análise desse construto pode fornecer subsídios para a melhoria do relacionamento e da satisfação plena de diversas necessidades do consumidor. No início dos anos 2000, observava-se que pesquisadores do comportamento do consumidor representavam quase a metade dos professores das escolas de marketing do mundo (Simonson et al., 2001).

Alguns autores como McGuire (1969), por meio de pesquisas em atitude e mudança de atitude, Wells e Tigert (1971) utilizando-se de estudos em Atividades, Interesses e Opiniões (AIOs) para explicar estilos de vida, e Plummer (1974) adotando estilos de vida para segmentar o mercado, dedicaram-se a explicar padrões de compra e comportamento de consumidores baseando-se nos seus perfis, motivados, em parte, pela competição acirrada por novos clientes, pelos efeitos decorrentes da globalização e pelas mudanças sociais advindas da transformação do comportamento do consumidor. Logo, o estudo deste comportamento de consumo se torna imprescindível para a formulação de estratégias de empresas em um contexto de competição acirrada. As pessoas possuem hábitos de compra variados, gostos diferenciados e têm diferenças em relação às suas necessidades, desejos, preferências, sentimentos e percepções (Kotler, 2006). Alguns estudiosos afirmam que há diversas maneiras pelas quais os profissionais de marketing podem agrupar os consumidores, entre elas, pela observação das suas características e pela utilização de determinados produtos ou serviços (Wind, 1978; McDonald \& Dunbar, 1995; Siqueira, 2000). Essas maneiras, segundo tais estudiosos, procuram revelar características demográficas, geográficas, socioeconômicas, de personalidade e comportamentais do mercado-alvo. No entanto, de acordo com Solomon (2002), embora os consumidores possam partilhar das mesmas características demográficas, eles ainda assim são pessoas diferentes, uma vez que seus estilos de vida, atitudes e valores, podem diferir-se consideravelmente. Desse modo, visto que as informações geradas apenas pela demografia não abordam diretamente as necessidades e desejos que levam os consumidores a realizar suas compras (McDonald \& Dunbar, 1995), uma simples característica, como diferenças entre grupos, baseadas em faixas etárias, parece não ser suficiente para a explicação de padrões de compra, sendo assim necessária uma análise mais profunda acerca de suas preferências. Diante deste cenário, a presente pesquisa buscou investigar a maneira como os consumidores sofrem influências de características internas e estas afetam o modo como tais variáveis afetam as avaliações que os indivíduos fazem de um bem. 
Em um país de dimensões territoriais amplas, como o Brasil, espera-se que exista diferença entre perfis de consumo não só inter como também intrassegmentos de mercado, os quais são referenciados na literatura internacional como homogêneos (Mowen \& Minor, 2003). Solomon (2002) propõe que a segmentação feita com base em idade é capaz de estabelecer diferenciação clara em termos de características psicológicas, para assim predizer padrões de consumo específicos.

As diferentes formas de compreensão da realidade, interesses, atitudes, valores e demais variáveis, comumente resumidas sob a noção de características psicológicas, influenciam diretamente as preferências de consumo dos indivíduos, o que se relaciona, por sua vez, com o padrão de compra de cada um (Sheth, Mittal \& Newman, 2001). Salienta-se que a literatura que aponta a influência da demografia e das características psicológicas no consumo é predominantemente estadunidense, sendo a produção brasileira majoritariamente apoiada nesses estudos (Tomanari, 2003).

Todavia, pode-se fazer tal afirmativa no Brasil? Evidências sugerem a existência de diferenças nos valores endossados entre brasileiros, de modo que o país não pode ser considerado como um só grupo cultural. Por exemplo, a forma de lidar com a desigualdade de poder e status social apresenta grande variância entre brasileiros da Região Norte e Sudeste (Torres \& Dessen, 2008), assim como a preferência por estilos de consumo mais individualistas ou coletivistas. Diversas pesquisas têm investigado a estreita relação entre o comportamento do consumidor e os valores culturais em âmbito mundial, porém, poucos esforços têm sido realizados especificamente para o Brasil. Assim, é fundamental entender o contexto de pesquisa proposto pelo presente trabalho.

\subsection{Contextualização e Justificativa}

Tendo em vista que em mercado não há homogeneidade entre seus membros, isto é, as pessoas possuem hábitos de compra variados, gostos diferenciados e variam em termos de suas necessidades, desejos, preferências, julgamento, sentimentos e percepções, vários estudiosos (Wind, 1978; Mcdonald \& Dunbar, 1995; Siqueira, 2000) afirmam que há diversas maneiras pelas quais os profissionais de marketing podem agrupar os consumidores tanto por meio da observação das suas características como pelas respostas a determinados produtos ou serviços. Essas maneiras, segundo esses autores, procuram revelar certas características geográficas, socioeconômicas, de personalidade e comportamentais do mercado-alvo. No entanto, de acordo com Solomon (2002), embora os consumidores possam partilhar das 
mesmas características demográficas e geográficas, eles ainda assim são pessoas diferentes, uma vez que seus estilos de vida, atitudes e valores etc., podem diferir de forma considerável.

Desse modo, visto que as informações geradas pela demografia e geografia não abordam diretamente as necessidades e desejos que levam os consumidores a efetuarem aavaliação de produtos e realizarem suas compras (McDonald \& Dunbar, 1995), entre as diversas tipologias de segmentação existentes, a utilização de variáveis psicológicas vem se tornando um meio eficiente para identificar os consumidores e descrever suas diferenças por intermédio de dimensões psicológicas.

Diversos estudos já apresentaram correlação entre as idade e o consumo. Belleau, Summers, Xu e Pinel (2007) caracterizaram a intenção de consumo em jovens, Short e Reeves, (2009) pesquisaram como as gerações gostam de ler quadrinhos, Kim, Knight e Pelton, (2009) estudaram a modelagem de valor de marca para a geração de jovens na Coreia do Sul, Lehto, Jang e O'Leary, 2008 compararam o consumo de turismo das gerações de idosos, Cleaver, Green e Muller, (2000) pesquisaram sobre o consumo turístico também da geração de idosos. No Brasil, Barcelos (2010) pesquisou o consumo de mídias pelos adolescentes e Laux, Almeida e Pereira (2008) estudaram o consumo de refrigerantes nas diferentes gerações.

Assim, estudar a inflência da idade no Brasil nos hábitos de consumo justifica-se pela raridade de estudos nacionais sobre o tema gerações e sua possível contribuição para a literatura de Marketing como composto de segmentação de mercado em termos psicológicos, além de contribuir para o estudo de comportamento de consumo no que tange à sua capacidade de predizer o consumo de produtos de modo satisfatório. Apesar de esta segmentação ser abordada por autores de comportamento de consumo e marketing (Boone \& Kurtz, 1998; Kotler, 2006; Mowen \& Minor, 2003; Engel, Blackwell \& Miniard, 2000, pouco espaço foi dedicado à sua operacionalização e implementação, especialmente no Brasil. A segmentação do mercado com o auxílio de variáveis tipicamente utilizadas pela psicologia (e.g., atitudes, valores, personalidade) tem sido chamada na literatura de Marketing como segmentação psicológica, termo que será adotado no presente trabalho. A maior parte dos estudos de segmentação e pesquisa mercadológica refere-se à segmentação demográfica de sexo e renda (Finotti, 2004), o que leva a criar questionamentos sobre a relação entre consumo e idade no Brasil.

O comportamento do consumidor resulta de preferências entre alternativas, ou seja, julgamentos e avaliações, as quais são sistematicamente relacionadas com características psicológicas (Mowen \& Minor, 2003). Assim, os modelos utilizados para a compreensão do 
comportamento de consumo utilizam como ferramenta a segmentação do mercado, para, então, identificar e propor a medição de respostas de consumo (Peter \& Olson, 1993). Entre os modos de segmentação reconhecidos na literatura (Kotler, 2006; Solomon, 2002, a segmentação psicológica é considerada como uma das mais completas como um critério para se dividir o mercado.

É frequente na literatura o mapeamento cultural de grupos de idades semelhantes, ao longo do Século XX (Mannheim, 1952; Ryder, 1965; Sheth, Mittal \& Newman, 2001; Arnould, Price \& Zinkhan, 2004), demonstrando hábitos e crenças ligados à situação histórica que o mundo vivia naquele momento; esse mapeamento cultural dividido por parcelas de idades é observado com variações de datas de nascimento, provavelmente, devido ao fato de que nem sempre os membros daquela parcela de idade possuem os mesmos hábitos e devido à variação da localidade e ao método de pesquisa utilizado para definir os limites de agrupamento das idades. O fato de tais levantamentos serem frequentes, porém não empíricos, produz questionamento pertinente sobre a influência da idade no consumo, a ser trabalhado na próxima sessão.

\subsection{Pergunta de Pesquisa}

Visto que as informações geradas apenas pela demografia não abordam diretamente as necessidades e desejos que levam os consumidores a realizar suas compras (McDonald \& Dunbar, 1995) uma simples característica, como idade, parece não ser suficiente para a explicação de padrões de compra, uma vez que os estudos apontam sua relação direta ao consumo. Sendo assim, torna-se necessária uma análise mais profunda da influência da idade no consumo por intermédio do estudo da sua relação com variáveis psicológicas utilizadas nesse estudo, a saber, Tipos de Julgamento e Atribuição de Significado e Valores. Os tipos de

julgamento adotados são os propostos por Allen (1997), e subdividem-se em Julgamento Afetivo, que é apresentado como um julgamento predominantemente holístico, e Julgamento Passo a Passo que é um julgamento fracionado e predominantemente racional.

Os Valores podem ser definidos de forma simplificada, segundo Schwartz (1992, p.22), "defino valores como conceitos do desejável que guiam a vida de atores sociais (e.g., líderes organizacionais, criadores de leis, indivíduos), selecionam ações, avaliam pessoas e eventos e explicam suas ações e avaliações”. Apesar de Valores possuírem várias definições e escalas de autores diversos, de suas escalas originais terem sido desenvolvidas para a língua inglesa e, em função de a produção brasileira na área de consumo apoiar-se nos estudos 
realizados nos EUA, embora evidências empíricas e teóricas apontem diferenças entre os dois países, pergunta-se:

Qual a influência da idade e dos valores dos indivíduos no julgamento de automóveis no Brasil e nos Estados Unidos da América?

\subsection{Objetivo do Estudo}

\subsubsection{Objetivo geral}

Definir a influência entre Idade, os Valores, o Julgamento e a Atribuição de Significado em relação ao consumo de automóveis no Brasil e nos Estados Unidos da América.

\subsubsection{Objetivos específicos}

- Medir os Valores Pessoais, conforme proposto por Kahle e Kennedy (1988), em individuos de diferentes idades no Brasil e nos Estados Unidos

- Medir os Valores Humanos como propostos por Schwartz et al. (2012) em individuos de diferentes idades no Brasil e nos Estados Unidos

- Identificar e comparar o Tipo de Julgamento e Atribuicao de Significado conferido pelos brasileiros e estadunidenses acerca de avaliacao de automoveis.

- Comparar a influencia dos Valores Pessoais, conforme proposto por Kahle e Kennedy (1988), e Valores Humanos como propostos por Schwartz et al. (2012) na predicao dos tipos de Julgamento e Atribuicao de Significado

- Verificar a relação da idade com as variaveis psicologicas de Valores, Julgamento e Atribuicao de Significado no contexto de consumo de automovel.

O objetivo geral e os objetivos específicos, por consequência, demandam o levantamento de hipóteses relativas à presente pesquisa. Na tabela 1 são apresentadas as hipóteses de pesquisas: 
Tabela 1

Hipóteses de pesquisa

Hipóteses

H1: O Julgamento Afetivo para a compra de automóveis será predominantemente superior no Brasil comparativamente com os Estados Unidos da América.

H2: O Julgamento Passo a Passo para a compra de automóveis será predominantemente superior nos Estados Unidos da América comparativamente com o Brasil.

H3: Os Valores Pessoais são capazes de predizer os tipos de Julgamento e Atribuição de Significado para automóveis no Brasil e nos Estados Unidos da América.

H4: Os Valores Humanos são capazes de predizer os tipos de Julgamento e Atribuição de Significado para automóveis no Brasil e nos Estados Unidos da América

H5: Valores Pessoais conjuntamente com Valores Humanos predizem melhor os tipos de Julgamento e Atribuição de Significado para automóveis do que separadamente no Brasil e nos Estados Unidos da América.

H6: A idade influencia o modo como estadunidenses e brasileiros julgam automóveis.

H7: O Modelo de pesquisa apresenta-se de maneira semelhante no Brasil e nos Estados Unidos da América.

Fonte: $\mathrm{O}$ autor

Para alcançar os objetivos propostos, é necessário apresentar o referencial teórico, divido em três pontos: comportamento de consumo com seu histórico e definições, segmentação com definição e tipos de segmentação, Valores, idade e por fim o estado da arte sobre comportamento do consumidor no Brasil e consumo de automóveis no mundo. 


\section{REFERENCIAL TEÓRICO}

\section{O Comportamento do Consumidor}

\subsection{Histórico e Definição da Área}

No intuito de melhor compreender o comportamento de consumo, considerado uma parte do comportamento humano, houve, desde os primórdios da disciplina, uma forte tendência a buscar, em outras áreas do conhecimento (na sociologia, na psicologia cognitiva e na antropologia cultural), possíveis caminhos para o entendimento do comportamento do consumidor (Sheth, Gardner \& Garret, 1988). Pinheiro e Castro (2006) ampliam o conceito de comportamento do consumidor apontando que esta é uma área interdisciplinar, que envolve conceitos e teorias de diferentes áreas do conhecimento, tais como psicologia, economia, sociologia, antropologia cultural, semiótica, demografia e história. Juntamente com o corpo teórico, foram trazidas daquelas áreas do conhecimento metodologias e técnicas próprias. Como demonstra Hunt (1991), a história do comportamento do consumidor tem sido caracterizada pela utilização aberta de métodos e teorias diferentes, originados de fontes muito variadas. Giglio (1996) e Sandhusen (1998) sugerem que a compreensão do comportamento do consumidor e o seu desenvolvimento teórico devem-se ao fato de ter sempre reunido contribuições advindas das ciências sociais ainda que Karsaklian (2009) saliente que, apesar de inicialmente ter pensado que as contribuições de cada disciplina eram equivalentes, claramente a mais utilizada é a psicologia.

Lemos (2010) aponta que as pesquisas sobre o comportamento do consumidor são, portanto, ferramentas que auxiliam os gestores a traçar seus objetivos, compreender os significados e as mensagens expressas pela posse de produtos e identificar os desejos e expectativas dos clientes, em cada mercado específico, o que pode ser o observado pela descrição de Mowen e Minor (2003, p. 3) que descrevem que "o comportamento do consumidor é definido como o estudo das unidades compradoras e dos processos de troca envolvidos na aquisição, no consumo e na disposição de mercadorias, serviços, experiências e ideias". Partindo do ponto de vista teórico, o intuito de compreender o comportamento do consumidor tem acontecido por meio do desenvolvimento e explicitação de modelos analíticos, que se propõem a retratar o mundo real em que estão presentes os processos de decisão de compra dos produtos e suas respectivas variáveis. Estudos como os de Markin (1979), Kassarjian (1981), McAlister e Pessemier (1982) e Ferber (1984) organizam muitas 
variáveis explicativas de diferentes modelos analíticos do comportamento de compra do consumidor.

Tais modelos, cujas origens remontam ao século 19 em estudos de propaganda (Scripture, 1985) e seguem até os dias de hoje, têm em comum o fato de sempre estarem diretamente embasados na Economia, na Psicologia, na Sociologia ou na Antropologia, ainda que alguns deles recebam, em suas descrições, variações matemáticas ou estatísticas (Kuehn \& Day, 1964). Pinto e Lara (2007) apresentam um resumo esquemático da evolução da área de comportamento do consumidor, conforme tabela 2.

Tabela 2

Evolução da escola de comportamento do consumidor

\begin{tabular}{|c|c|}
\hline Década & Comentários \\
\hline \multirow{5}{*}{ Década De 1950} & Nesta década, identificam-se três separadas áreas de pesquisa: \\
\hline & 1 - Determinantes psicológicos do comportamento do consumidor \\
\hline & 2 - Determinantes sociais do comportamento do consumidor; \\
\hline & 3 - Tomada de decisão por parte do consumidor. \\
\hline & $\begin{array}{l}4 \text { - Criação da divisão de psicologia do consumidor na American } \\
\text { Psychological Association (APA). }\end{array}$ \\
\hline \multirow{6}{*}{ Década De 1960} & $\begin{array}{l}\text { Um grande número de estudiosos de diferentes áreas começou a focar } \\
\text { esforços para a área de comportamento do consumidor. Linhas de } \\
\text { pesquisas: }\end{array}$ \\
\hline & 1 - Lealdade à marca de produtos de mercearias; \\
\hline & $\begin{array}{l}2 \text { - Utilização do método de experimentos no campo do } \\
\text { comportamento do consumidor }\end{array}$ \\
\hline & 3 - Teoria do risco percebido em comportamento do consumidor; \\
\hline & 4 - Teorias compreensivas de comportamento de compra. \\
\hline & $\begin{array}{l}\text { Nessa década, foi criada a mais conhecida teoria do comportamento } \\
\text { do consumidor que foi proposta por Howard e Sheth (1969). }\end{array}$ \\
\hline \multirow{6}{*}{ Década De 1970} & $\begin{array}{l}\text { Nos anos da década de 1970, houve a consolidação da ACR } \\
\text { (Association for Consumer Research), que foi fundada em } 1969 . \\
\text { Também houve a organização do JCR (Journal of Consumer } \\
\text { Research) em 1974. Novas linhas de pesquisas foram desenvolvidas: }\end{array}$ \\
\hline & 1 - Comportamento de compra industrial; \\
\hline & $\begin{array}{l}2 \text { - Estudo do comportamento de consumo de serviços públicos como } \\
\text { cuidados da saúde, transporte, nutrição etc; }\end{array}$ \\
\hline & 3 - Comportamento de compra familiar; \\
\hline & 4 - Relacionamento entre atitude e comportamento; \\
\hline & 5 - Processamento de informação. \\
\hline
\end{tabular}


Nessa década, a ênfase das pesquisas recaiu sobre temas como rituais e simbolismo, comportamento de fantasia e experimentação e o

Década De 1980 impacto da religião no comportamento do consumidor. Também houve uma corrente contra a mensuração quantitativa nas pesquisas e uma maior preferência por mais pesquisas de tradição qualitativa.

A partir dos anos 1990, aconteceu o desenvolvimento do marketing de relacionamento. Assim, passou-se a discutir mais tópicos como atitudes de consumidores, relações pessoais, tendências de comportamento, entre outros fatores socioculturais. Os estudos passam a preocupar-se também com a contextualização do ambiente.

Década De 1990 Podem-se assinalar também as melhorias das avaliações quantitativas proporcionadas pelo avanço tecnológicos e softwares poderosos de análise de dados. Pode-se afirmar que nessa década, houve crescimento nesse campo do movimento conhecido como pósmodernismo - uma forma de investigação que inclui objetivos e métodos diferentes.

A entrada do novo século estabelece uma perspectiva do comportamento do consumidor baseada em um "marketing Década De 2000 experiencial", ou seja, a sensação de que os produtos e serviços proporcionam aos consumidores experiências sensoriais, afetivas, cognitivas, físicas e sociais. Assim, estes passam a ser os novos determinantes de novos estudos do comportamento do consumidor.

\footnotetext{
Nota. Fonte: Pinto e Lara (2007)

Schumann, Haugtvedt e Davidson (2008) explicam que a consolidação da área de estudos ocorreu no final da década de 1950, especificamente em 1959, quando um grupo de psicólogos, que trabalhavam majoritariamente para empresas de propaganda e empresas de pesquisa em marketing e se encontravam regularmente para discutir sobre assuntos acadêmicos, se aproximaram da American Psycological Association (APA) para criar a divisão 23, chamada de "Psicologia do Consumidor". Até então, os assuntos tratados pela "Psicologia do Consumidor" eram rotulados como parte da Psicologia Organizacional (Schumann, Haugtvedt \& Davidson, 2008).

Embora na área de psicologia o termo tenha aparecido somente em 1962, em outras áreas o termo "Comportamento do Consumidor" como estudo de hábito de consumo data desde 1848, segundo Stigler (1954), em estudos de orçamentos pessoais e gastos. Haugtvedt, Herr e Kardes (2008) salientam que a área de estudo do consumo tornou-se mais popular com a publicação dos primeiros livros sobre Comportamento do Consumidor (Nicosia, 1966; Myers \& Reynolds, 1967; Engel, Kolat \& Blackwell, 1968; Howard \& Sheth, 1969) e a implantação da disciplina em várias faculdades.
} 
Sabe-se que o estudo do comportamento é uma das áreas de estudo do Marketing e da Psicologia e é, inclusive, possível a afirmação de que a Psicologia do Consumidor é uma área mais abrangente que a do Comportamento do Consumidor. Por outro lado, livros intitulados "Psicologia do Consumidor", como o de Gade (1980), abordam praticamente os mesmos temas que livros com o título de "Comportamento do Consumidor". Inclusive, nos últimos anos, o termo "Comportamento do Consumidor" tem sido mais utilizado que "Psicologia do Consumidor". Ainda que o termo "Comportamento do Consumidor" se refira, em termos estritos, como o comportamento em si, a própria definição é composta por características que transcendem o comportamento específico, como pode ser observado pela descrição de Hawkins, Mothersbaugh e Best (2007, p.4):

O campo do comportamento do consumidor envolve o estudo de indivíduos, grupos ou organizações e o processo que eles usam para selecionar, obter, usar e dispor de produtos, serviços, experiências ou ideias para satisfazer necessidades e o impacto que esses processos têm sobre o consumidor e a sociedade.Wänke (2009) aponta que o comportamento de consumo encontra suas raízes na psicologia social; assim, as teorias aplicadas no contexto de consumo são advindas ou governadas pela área de psicologia social, que tem por definição ser o "estudo científico da influência recíproca entre as pessoas e do processo cognitivo gerado por essa interação" (Rodrigues, Assmar \& Jablonky, 2000, p.13). Wänke (2009) ainda aponta que é função da psicologia social estudar o comportamento social e isso, geralmente, está relacionado a estudar o comportamento de consumo ou o comportamento em um contexto de consumo; portanto, estudar o comportamento de consumo é parte genuína da psicologia social. Assim, utilizar o termo "comportamento do consumidor" é mais apropriado, uma vez que o foco do Marketing é entender o consumidor para que este gere comportamento de compra e não somente intenção de compra. Porém, apesar de o foco do Marketing ser comportamental e não atitudinal, diversos estudos (Fazio, 1990; Fazio, Powell \& Williams, 1989; Snyder \& Kendzierski, 1982), apresentaram a relação entre atitudes e comportamento; portanto, entender as atitudes dos consumidores é parte fundamental para gerar comportamento de compra.

Atitudes são definidas como "um processo geral de compreensão das coisas em termos de bom ou ruim, apropriado ou inapropriado conveniente ou inconveniente, que você assume uma "posição" frente ao mundo que o cerca; essa "posição" é chama de atitude" (Torres \& Neiva, 2011, p.171). A definição de Triandis (1991) engloba o aspecto comportamental que define atitude como "estado de uma pessoa que a predispõe a uma resposta favorável ou desfavorável quanto a um objeto, pessoa ou ideia (Triandis, 1991, 
p.485). Allport (1935, p.19) define atitude como "um estado mental e neurológico de prontidão, organizado por meio da experiência, exercendo uma influência diretiva ou dinâmica obre a resposta do indivíduo a todos os objetos e situações com que se relaciona". Torres e Neiva (2011) frisam o caráter das implicações comportamentais da definição de Allport (1935) como "um todo apto a reagir de uma certa maneira" (Torres \& Neiva, 2011).

É comum na literatura sobre atitudes interpretá-las como um construto composto por três partes, cognitiva, afetiva e comportamental (Ajzen \& Fishbein, 1997). O componente cognitivo ou de conhecimento representa as informações do indivíduo sobre um objeto: a consciência da existência do objeto, crenças a respeito das características do objeto e julgamentos sobre a importância relativa a cada um desses atributos. Já o componente afetivo está ligado aos sentimentos que se tem em relação ao objeto, por exemplo, em termos da polaridade desfavorável-favorável. A preferência por esse objeto, em detrimento de outros, reflete o fator afetivo. O componente comportamental, por sua vez, está unido à ação: as intenções em relação ao objeto (adquiri-lo ou não, recomendá-lo etc.).

Uma vez que a atitude influencia a postura de um indivíduo frente a um objeto e o modo como este se relaciona com ele, os indivíduos podem ter diferentes atitudes sobre um mesmo objeto. Tal diferenciação permite não só entender melhor os indivíduos do ponto de vista psicológico como segmentá-los, a fim de tratá-los de maneira mais adequada frente aos objetivos de Marketing. Desta maneira, faz-se necessário compreender a segmentação e suas características, a fim de se adequar ao presente estudo. Tal descrição é apresentada a seguir.

\subsection{Segmentação}

Para lançar um produto no mercado é importante que a empresa tenha o seu públicoalvo definido. É imprescindível que se defina qual segmentação irá trabalhar; para Weinstein (1995), a segmentação é o processo de dividir mercados em grupos de consumidores potenciais, cada um com suas características, necessidades, comportamento e estilo de vida similares. Segundo Mancebo et al. (2002), particularmente no contexto atual, a oferta de novas mercadorias é intensa e múltipla, também é grande a incidência de usurpação dos bens qie demonstram statusl social por grupos de mais baixo status, provocando deste modo uma certa banalização de conjuntos de bens. Tal fato produz um efeito de perseguição infinita por diferenciação, segundo a qual "os de cima serão obrigados a investir em novos bens a fim de restabelecer a distância social original" (Featherstone, 1995, p. 38). Em outros termos, sob o prisma da distinção, o que rege a apropriação dos bens não é a satisfação das necessidades, 
mas a escassez desses bens e a impossibilidade de que outros os possuam (Mancebo et al., 2002)

O mercado contém diversos grupos com necessidades específicas. Por mais bem sucedida que uma empresa seja, não é possível atender perfeitamente vários públicos. É necessário segmentar para poder atender a todas as suas necessidades com produtos e/ou serviços exclusivos, como afima Solomon (2002), na medida em que a sociedade evolui, torna-se mais importante identificar os diferentes tipos de segmentos de mercado e desenvolver mensagens e produtos direcionados para cada grupo. Os grupos possuem sentimentos, percepções e comportamentos semelhantes; assim, eles correspondem de forma similar às estratégias direcionadas a eles. Como afirma Weinstein (1995), a pesquisa de segmentação tem por objetivo encontrar oportunidades no mercado. Desta forma, a segmentação traz para a empresa pontos positivos referentes a incremento nas vendas, aumento da participação de mercado, sustentação da marca e melhora na posição competitiva da empresa (figura 1).

De acordo Kotler (2006), não existe uma única receita para segmentar o mercado. Os profissionais de marketing devem testar diferentes variáveis de segmentação, isoladas e combinadas, para encontrar a melhor forma de visualizar a estrutura do mercado, conforme figura 1.

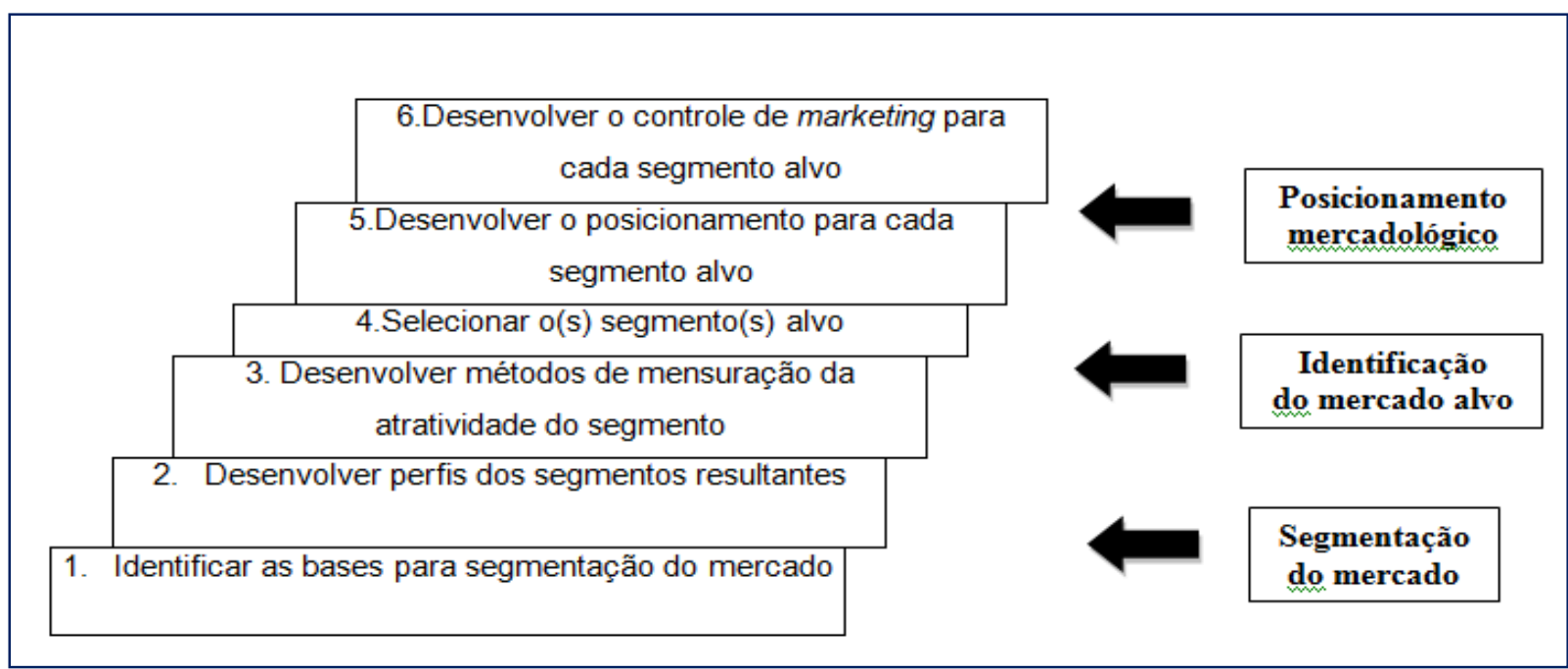

Figura 1. Variáveis de Segmentação

Fonte: Kotler (2006)

Segmentação está no centro do próprio conceito de marketing, como descrevem Rees e Gardner (2005) e Statt (1997), e é considerada o mais fundamental conceito no marketing moderno (Wind, 1978). Para Arnould, Price e Zinkhan (2004), a segmentação é uma ferramenta fundamental para o estudo do comportamento de consumo, pois permite o 
estabelecimento da correspondência mental entre o significado de um produto e o autoconceito do consumidor. Segundo Bourdieu (1974, 1975), o acúmulo de bens de consumo muito específicos atesta o gosto e a distinção de quem os possui; de modo cultural ou simbólico, as escolhas não são as mesmas para todo e qualquer cidadão. Baudrillard (1991) aponta que o consumo é regido por uma lógica das significações, em que tudo se converte em signo (até as ideologias, as religiões, os estilos e as atitudes), criando, assim, o que Bauman (2008) chama de subjetividade do consumidor:

A subjetividade do consumidor é feita de opções de compra, ou seja, opções assumidas pelo sujeito e seus potenciais compradores; sua descrição adquire a forma de uma lista de compras. O que se supõe ser a materialização da verdade interior do self é uma idealização dos traços materiais "objetificados" das escolhas do consumidor construído por meio da compra e venda dos símbolos empregados na construção de uma identidade (Sirgy, 1982). Tal definição de construção do "self" (Sirgy, 1982) é semelhante ao "simulacro" de Baudrillard (1991), em que o consumidor coloca a "representação" no lugar do que esta deve representar e inclui a ideia do que a pessoa é atualmente (self real) e também do que ela gostaria de se tornar (self ideal). Os conceitos de "self" (Sirgy, 1982), "subjetividade do consumidor" (Bauman, 2008) e "simulacro" (Baudrillard, 1991) representam de forma ampla o autoconceito, como definido por Sheth, Mittal e Newman (2001) como "auto-imagem", uma ideia de como a pessoa atualmente é e também do que gostaria de se tornar.

Grubb e Grathwohl (1967) foram os primeiros que propuseram a utilidade do construto autoconceito. Eles argumentavam que o conceito do Self é mais restrito que o de personalidade, o que facilita a mensuração e centralização sobre o elemento crítico de como o indivíduo percebe a si mesmo. Os autores propuseram a utilidade do autoconceito no entendimento do comportamento do comprador. O autoconceito influencia o consumo das pessoas, as quais vivem seus autoconceitos em grande medida por meio do que consomem. A congruência entre o autoconceito do indivíduo e sua escolha do que consumir tem encontrado suporte na literatura (Torres \& Allen, 2009).

Solomon (2002 acredita que o consumo de produtos e serviços contribui para a definição do eu, pois o cliente, como um ator que representa o seu papel, precisa de acessórios e ambientação correta para poder atuar. E, justamente esses acessórios, que são os produtos consumidos, representam como uma parte da extensão do eu. Sheth, Mittal e Newman (2000) afirmam que os profissionais de marketing podem aplicar o princípio do autoconceito para obter um perfil dos seus clientes, pois os autoconceitos influenciam o consumo das pessoas: as pessoas vivem seus autoconceitos em grande medida pelos produtos 
que consomem. Uma vez que as pessoas possuem autoconceitos diferentes, as pessoas irão buscar produtos distintos para satisfazer seu autoconceito, permitindo, assim, a segmentação de produtos.

Segmentação, segundo Mowen e Minor (2003), "é definida como a divisão de um mercado em subconjuntos distintos de cliente com necessidade e vontades semelhantes" (p.32). A ideia de segmentar mercados não é recente e foi trazida por Smith (1956) na Economia (Porto, 2005). Smith (1956), na década de 1950, destacava a necessidade de segmentar mercados para melhor atender às demandas dos consumidores, já que, com o advento da produção em massa, os consumidores eram tratados como um grande e indiferenciado mercado (Statt, 1997). Sem ela, seria árdua a tarefa de satisfazer a uma grande variedade de desejos, necessidades e comportamentos, de forma indistinta. De tal modo, profissionais que trabalham em áreas concernentes aos consumidores buscam identificar a quantidade e a natureza dos grupos de consumidores para quem irão ofertar seus produtos ou serviços (Porto, 2005). Em uma era, cujo foco está na sociedade e no seu desenvolvimento, não se abarcar estratégias de segmentação na propaganda parece um contra-senso (Smith \& Hirst, 2001).

Wind (1978) faz diferenciação entre duas estratégias de segmentação. Na primeira, as variáveis são escolhidas antes de se realizar a coleta das informações, isto é, a escolha das variáveis é a priori. Alguns exemplos de variáveis dependentes na utilização dessa estratégia são compras passadas e lealdade ao produto. Outra possibilidade é utilizar uma estratégia de agrupamento, na qual as variáveis são a base para agrupamentos de consumidores, como a reunião de segmentos que possuem determinada atitude, ou valores, em um determinado agrupamento. Entre as diversas maneiras para segmentar um mercado, encontram-se reunidas em quatro grandes grupos as chamadas bases de segmentação, que se dividem em segmentação comportamental, segmentação geográfica, segmentação demográfica e segmentação psicológica (Kotler, 2006).

\subsection{Segmentação comportamental}

Hooley \& Saunders (1993) descrevem que o método mais direto de segmentação de mercado é baseado no comportamento do consumidor. A segmentação comportamental abrange compras, consumo, comunicação e reação a elementos do mix de marketing, o que completa o pensamento do Kotler (2006), quando diz que os segmentos de mercado podem ser identificados de diversas maneiras; uma delas é embasada em segmentos por preferências. Partindo deste princípio, Weinstein (1995) descreve que mercados são pessoas. Por meio da 
pesquisa e análise do comportamento do consumidor, os profissionais de marketing podem compreender melhor o que os compradores esperam do produto e/ou serviço. Em resumo, cada consumidor tem sua preferência dentro do mercado.

De acordo com Hooley \& Saunders (1993), o estudo do comportamento de compra gira em torno do momento da compra e dos padrões de compra. Com base nesse estudo é possível distinguir dois tipos de consumidores:

a) Inovadores - tipo de consumidor que compra tudo o que é novidade no mercado. Eles têm recebido muita importância dos profissionais de marketing;

b) Leais à marca - a lealdade à marca também tem sido usada como base de segmentação. Enquanto os inovadores preocupam-se com a compra inicial, os padrões de lealdade estão relacionados com a repetição da compra. Em função disso, eles são mais aplicáveis a bens com compras repetidas do que a bens de consumo duráveis, apesar de também já terem sido usados em mercados de bens de consumo duráveis. Tal como no caso da pesquisa de comportamento inovador, não tem sido possível identificar consumidores que apresentam uma lealdade à marca em uma grande variedade de produtos. A lealdade, como a inovação, é especifica a um determinado campo de produtos.

\subsection{Segmentação geográfica}

De acordo com Weinstein (1995), não existe um único método para segmentação geográfica do mercado. Os fatores a serem considerados incluem o mercado em que se está competindo. Na identificação e seleção de segmentos de mercado, os profissionais de marketing avaliam residências, vizinhanças, idade, ocupação, educação dos consumidores, além de outras características.

A segmentação geográfica constitui um dos métodos mais simples para se dividir mercados em possíveis segmentos-alvos. Por isso, esta abordagem constitui o primeiro passo a considerar, ao se segmentar mercados. O lugar onde as pessoas vivem, trabalham e se divertem tem grande impacto em seu comportamento de compra. Baseando-se nesse princípio, Cobra (2009) reforça o conceito de Weinstein, quando descreve que cidade, população, desenvolvimento, clima, tamanho da cidade, altitude são algumas das variáveis estudadas na segmentação geográfica. A empresa que se atenta a esses fatores pode optar por atender a todas ou a algumas das variáveis geográficas. Kotler (2006) reforça que, com esse estudo, a empresa consegue identificar onde estão situados seus clientes atuais e trabalhar 
com clientes em potencial que moram nessa região. Com isso, pode-se trabalhar melhor o produto para ter características mais parecidas com o cliente.

\subsection{Segmentação demográfica}

Kotler (2006) descreve que, na segmentação demográfica, o mercado é dividido em grupos de variáveis básicas. As variáveis demográficas são os meios mais populares de distinguir grupos de clientes por várias razões. Uma delas é o desejo dos consumidores por uma determinada marca. Os estudos demográficos, para Solomon (2002), são essenciais para os profissionais de marketing, pois esses podem analisar os dados e visualizar o tamanho do mercado, e, com isso, vender diversos produtos, utilizando a comunicação direcionada para o público alvo. De acordo com Kotler (2006), o estudo da segmentação comportamental facilita a identificação pelos seguintes grupos:

a) Idade - segundo Solomon (2002) pessoas da mesma faixa etária têm gostos, desejos e experiências em comum, portanto as estratégias de marketing são direcionadas para atender à demanda desse grupo. Depois de conquistar esses consumidores, as estratégias podem ser alteradas com o objetivo de expandir e conquistar públicos de outras faixas etárias. Arnould, Price e Zinkhan (2004) afirmam que utilizar a idade para segmentar, aprofundar e posicionar estatégias de Marketing é útil em três aspectos:

- As necessidades das pessoas modificam-se com o processo de envelhecimento e o acesso a recursos financeiros também varia com a idade;

- Mudanças na idade das pessoas geram mudanças na vida dos indivíduos e estas são gatilho para a entrada em estados sociais diferentes como entrar na faculdade, graduar no colégio ou na faculdade, adentrar a vida adulta, aposentar-se, comemorar aniversários de casamento, entre outros que geram demanda por tipos específicos de produtos;

- Pessoas que nasceram em períodos específicos de tempo possuem experiências compartilhadas e valores similares que guiam suas preferências de consumo;

b) Classe social - cada classe social possui poder de compra diferente. Para isso, os serviços e produtos são produzidos para atender especificamente cada grupo. Os grupos que têm ocupações equivalentes na sociedade têm desejos parecidos e não se privam de fazer altos investimentos em bens e serviços para sua qualidade de vida;

c) Gênero - apesar de haver produtos que agradam homens e mulheres, as características dos produtos específicos para cada gênero são diferenciadas, principalmente em relação a cor, cheiro, tamanho e textura; 
d) Estrutura familiar - cada estrutura familiar consome produtos com certa rotina. Há produtos que são consumidos com frequência em residências de família com filhos (como iorgute, frutas, biscoitos), outros em família de idosos (alimentos orgânicos) e diversos em residências de jovens solteiros (bebida, biscoitos);

e) Sexo - de acordo com Kotler (2006), homens e mulheres costumam ter orientações e atitudes comportamentais diferentes, devido em parte a características genéricas, em parte ao tipo de socialização. As mulheres costumam assimilar informações do ambiente em que vivem; já os homens tendem a focar a parte do ambiente que lhes permite atingir um objetivo;

f) Renda - a segmentação por renda é uma prática bastante utilizada em várias categorias de produtos e serviços. Entretanto, a renda nem sempre prevê o melhor cliente para o produto;

g) Fase da vida - indivíduos que estão no mesmo momento do ciclo de vida podem diferir da fase da vida em que se encontram;

h) Geração - cada geração é profundamente influenciada pela época em que foi criada. Um tipo de segmentação por geração é chamado de agrupamento, que são grupos de pessoas que compartilham experiências culturais, políticas, econômicas importantes. Embora existam distinções entre diferentes grupos, eles influenciam uns aos outros.

\subsection{Segmentação psicológica e estilo de vida}

De acordo com Blackwell, Miniard e Engel (2005), o termo segmentação psicológica surgiu com a utilização do termo Psychographics por Demby (1994), apesar de a definição só ser publicada bem depois, Tomanari (2003) aponta que Demby teve a ideia de empregar o termo em 1965, durante uma reunião com clientes. A proposta traçada por Demby (1994) era não adotar somente variáveis demográficas, mas também incluir variáveis que ele considerava pessoais, psicológicas (Tomanari, 2003).

Segundo Piirto (1991), o termo apareceu em 1965, em uma publicação da agência estadunidense Grey Advertising, na revista "Grey Matter" onde é descrita como "interesses da mente" e estaria voltado para o estilo de vida do individuo e o tipo de benefício procurado em um produto. Na área da psicologia, o termo "Psychograph" é definido por Allport \& Allport (1939) como qualquer característica psicológica de uma pessoa; além disso, esses autores apontam que a utilização do termo na psicologia data de 1921, quando Stern (1921) discute métodos psicográficos. 
No âmbito da Administração, Sheth, Mitall e Newman (2001) classificam variáveis psicológicas como psicografia e as definem como algo mais complexo que a demografia, ou seja, a caracterização psicológica adiciona atividades, interesses, opiniões, necessidades, valores, atitudes e traços de personalidade aos dados demográficos, que sozinhos apresentam utilidade limitada, permitindo assim caracterizar os consumidores nas diferentes dimensões psicológicas. Já Blackwell, Miniard e Engel (2005) apresentam a psicografia como técnica operacional para medir estilos de vida, especialmente aplicável para segmentação de mercado.

Arnould, Price e Zinkhan (2004) argumentam que a caracterização psicológica é a conexão entre as particularidades individuais e psicológicas para indicar padrões de comportamento e determinar um segmento de mercado. Segundo Sheth, Mittal e Newman (2001), a tipificação psicológica refere-se às características dos indivíduos que os descrevem em termos de sua constituição psicológica, como se ocupam e quais fatores psicológicos embasam esse padrão de atividade. Solomon (2002) aponta que a combinação de variáveis como personalidade e conhecimento sobre preferências de estilo de vida permite ir além de descrever quem compra algo, mas o motivo pelo qual esse algo é comprado; no entanto, para Weinstein (1995), as variáveis psicológicas já podem ser consideradas pesquisa de estilo de vida, e combinam as características de personalidade com os detalhes descritivos e orientados para o consumidor.

Segundo Kotler (2006), na segmentação psicológica, os compradores são divididos em diferentes grupos, com base no estilo de vida, na personalidade e nos valores. Pessoas do mesmo grupo demográfico podem ter perfis psicológicos diferentes. Kotler (2006) descreve que, além de itens da segmentação demográfica, a segmentação psicológica procura entender por que uma pessoa escolhe um produto específico para consumir. Como afirma Solomon (2002), a pesquisa demográfica descreve quem compra; entretanto, a psicológica diz por que o consumidor compra.

De acordo com Solomon (2002), o estudo da caracterização psicológica envolve diversos fatores, entre eles os psicológicos, sociológicos e antropológicos. O resultado dessa pesquisa de caracterização psicológica determina como o mercado é segmentado, levando em consideração as tendências dos grupos e seu estilo de vida. A figura 2 ilustra a evolução da psicografia em função de suas origens e influências: 


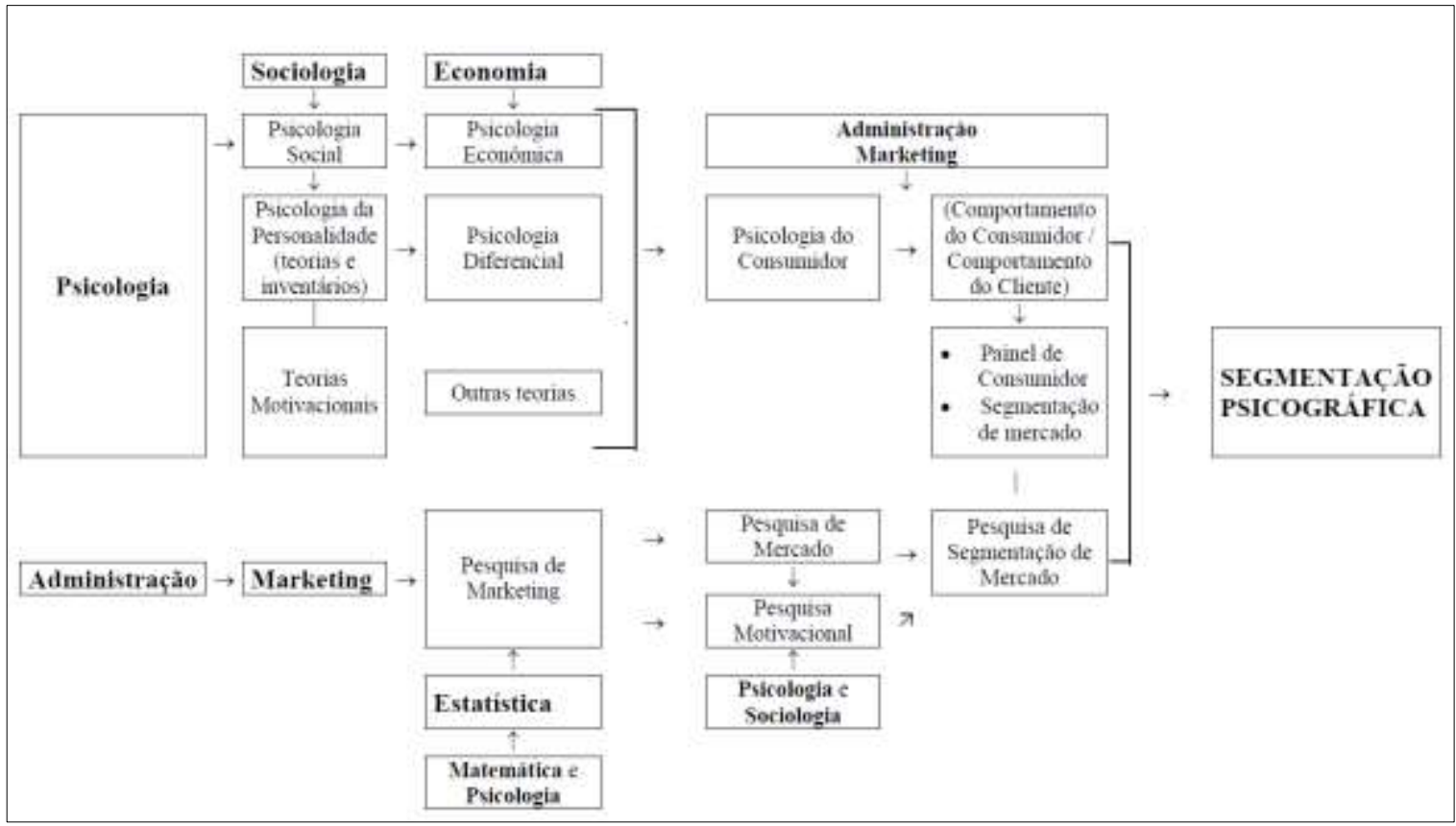

Figura 2. Origens e influências da segmentação psicológica

Fonte: Tomanari (2003)

Solomon (2002) aponta que o estudo da caracterização psicológica reconhece o que uma pessoa faz, como ela se comporta, seus valores e atitudes e pode tomar formas diferentes:

a) Perfil de estilo de vida - procura itens que diferenciam usuários e não usuários de um produto;

b) Perfil específico de produto - identifica um grupo alvo e, então, caracteriza os consumidores em dimensões relevantes para o produto;

c) Segmentação geral de estilo de vida - uma grande amostra de entrevistados é separada em grupos homogêneos com base nas semelhanças de suas preferências gerais;

d) Segmentação específica de produto - as questões são adequadas a uma categoria de produto.

De acordo com Solomon (2002), a caracterização psicológica ajuda os profissionais de marketing a adequarem as suas ofertas para atender as necessidades de cada segmento. $\mathrm{O}$ uso da segmentação psicológica pode ocorrer de várias maneiras, com os seguintes interesses específicos:

a) Definir o mercado alvo - as informações permitem que o profissional de marketing vá além das simples descrições demográficas ou do uso do produto; 
b) Criar uma nova visão do mercado - às vezes, os profissionais de marketing criam suas estratégias tendo em mente um cliente típico. Esse estereótipo pode não ser correto, pois o verdadeiro cliente pode não se adequar a essas pressuposições;

c) Posicionar o produto - as informações psicológicas possibilitam que o profissional de marketing enfatize características do produto que se adaptam ao estilo de vida de determinada pessoa. Os produtos direcionados a pessoas cujo perfil de estilo de vida mostram alta necessidade de estar com outras pessoas, poderiam concentrar-se na sua capacidade de auxiliar os usuários a satisfazerem essa necessidade social.

De acordo com Weinstein (1995), a empresa pode saber como se comportam os usuários de seus produtos, mas não conseguem saber por que eles compram. Por intermédio da pesquisa psicológica, a empresa pode estudar um determinado grupo de consumidores leais. Esta informação poderá ser utilizada em projetos futuros, eventos promocionais, bem como na prospecção de novos usuários potenciais como descrito abaixo:

- Comunicar os melhores atributos do produto - as informações psicológicas podem oferecer dados muito úteis para os criadores de comerciais que devem comunicar algo sobre o produto. $\mathrm{O}$ artista ou redator obtém uma imagem mental muito mais rica do consumidor almejado do que a obtida por meio de estatísticas e tal percepção melhora sua capacidade de falar com esse consumidor.

- Desenvolver uma estratégia global - a compreensão da forma como um produto se enquadra ou não nos estilos de vida dos consumidores permite que o profissional de marketing identifique novas oportunidades de produtos, mapeie estratégias de mídia e crie ambientes mais coerentes e harmoniosos com esses padrões de consumo.

- Acrescentar questões políticas e sociais no mercado - a segmentação psicológica pode ser um importante instrumento em campanhas políticas e também pode ser empregada para descobrir pontos em comum entre os tipos de consumidores que se envolvem em comportamento destrutivos, como o uso de drogas ou o excesso de jogo.

Weinstein (1995) descreve que as bases psicológicas, que são utilizadas em estudos de segmentação, como a identificação de mercado alvo, podem ser ferramentas fundamentais para conhecer bem os consumidores e suas bases demográficas. Os pesquisadores precisam ter a sensibilidade de captar o estado de espírito de cada consumidor para poder dividir o mercado em grupos segmentados, assim como um estudo bem completo do mercado alvo, como características de estilo de vida e o tamanho do mercado que se pretende alcançar. Os consumidores escolhem um produto porque o associam com certo estilo de vida, por isso 
Solomon (2002) relata o esforço das empresas para posicionar um produto e deixá-lo adequado a um padrão de consumo existente. Assim, faz-se necessário entender a construção de um "estilo de vida".

\subsubsection{Estilos de Vida}

Para a análise dos estilos de vida é importante utilizar-se do pensamento de Bourdieu \& Passeron (1979) sobre a distinção, que aponta as preferências por certos produtos, uma vez que podem atestar o gosto e a distinção de quem os possui, gerando diferenciação entre classes e grupos sociais. Mancebo et al (2002) apontam que, devido ao fato de a quantidade de itens de consumo ser extensa, torna-se limitada a avaliação do status ou posição hierárquica de um indivíduo somente por este utilizar ou possuir um bem. Assim, aspectos que transcendem a natureza física do produto passam a desempenhar papel importante como diferenciador de classes pois, por meio do julgamento, da preferência e do conhecimento simbólico do item, a formação do gosto passa a ser um mecanismo de diferenciação social.

Segundo Engel, Blackwell e Miniard (2000), o estilo de vida é um conceito mais moderno que o de personalidade, e refere-se ao dia a dia do consumidor, aos padrões de vida das pessoas e como despendem seu tempo e dinheiro. Para Blackwell, Miniard e Engel (2005), o termo representa o padrão de vida dos consumidores expresso em termos de atividades, interesses e opiniões (AIOs).

Segundo Solomon (2002), definir o estilo de vida do consumidor não é só observar como a renda é gasta. As pesquisas de nível econômico são importantes para identificar os grupos sociais e de interesses, de acordo com cada estilo de vida. Essa abordagem econômica é a afirmação de quem é o indivíduo na sociedade. Em resumo, esse estudo tem por objetivo mapear grupos que tenham as mesmas características, os lugares que frequentam e como gastam, para se fazer uma comunicação direcionada.

A caracterização psicológica descreve as pessoas em termos de estilos de vida ou do modo como elas vivem. Para Arnould, Price e Zinkhan (2004), os estilos de vida referem-se a um padrão de comportamento que reflete constelações de produtos, ou seja, grupos de produtos complementares, marcas e/ou atividades específicas. Os estilos de vida são determinados por: (a) características pessoais dos consumidores, como aspectos genéticos, raça, gênero, idade e personalidade; (b) características pessoais, como cultura, instituições, grupos de referência e seu valor pessoal; (c) por suas necessidades e emoções. Esses três conjuntos de fatores reunidos influenciam o padrão das atividades das pessoas, como elas 
gastam seu tempo e seu dinheiro. Os estilos de vida são avaliados por meio da ligação de fatores individuais psicológicos com padrões característicos de consumo, para assim determinar o mercado.

Partindo do pressuposto de que a formação de um estilo de vida é uma composição de características psicológicas, o entendimento desta análise baseia-se na compreensão das características psicológicas dos indivíduos. Grisi (1986) afirma que o estilo de vida atua como variável dependente de elementos psicológicos e demográficos, mas, dentro do comportamento de consumo, atua como variável independente a partir da qual se tenta explicar o consumo; assim, os profissionais de marketing das empresas que buscam conhecimentos sobre o que seu público alvo necessita devem entender como se apresentam tais características psicológicas, a saber, suas atividades, interesses, opiniões, valores, julgamento e atribuição de significado.

\subsubsection{Atividades, interesses e opiniões}

A psicografia, por meio das atividades, interesses e opiniões (AIO), descreve os estilos de vida das pessoas, baseados no que elas pensam, como vivem, gastam seus tempos disponíveis e como veem a si mesmas e o mundo ao seu redor (Mowen \& Minor, 2003; Samara \& Morsch, 2005; Sheth, Mittal \& Newmann, 2001; Solomon, 2002). As declarações de AIO podem ser usadas para pesquisar atividades e motivações gerais ou produtos e marcas específicos (Arnauld, Price \& Zinkhan, 2004). Como afirmam Mowen e Minor (2003), as questões muito específicas fornecem aos pesquisadores informações sobre o que os consumidores pensam a respeito do produto e a maneira como esses produtos se relacionam com eles. Com essas informações, produtos podem ser criados ou modificados juntamente com mensagem que estimule as suas vendas (Mowen \& Minor, 2003).

Karsaklian (2009) declara que existe uma distância entre a abordagem de valores e as preocupações de compra e consumo. A abordagem por produtos, por outro lado, é mais concreta, mas pouco generalizável: ela vincula-se satisfatoriamente às demais variáveis descritivas da demanda. A abordagem por atividades, interesses e opiniões (AIO) intermediárias procura compreender os consumidores, o que eles pensam ou fazem diante das situações da vida em sociedade como apresentado:

a) Atividades: são as ações observáveis praticadas pelas pessoas como lazer, trabalho, compras e o gasto do seu tempo.

b) Interesses: são as preferências e as prioridades dos consumidores baseadas no grau de excitação em relação a um objeto, evento ou assunto. 
c) Opiniões: são os pontos de vista, os sentimentos, as interpretações, expectativas e avaliações dos consumidores, em forma de resposta escrita ou falada a uma pergunta em relação a diferentes temas.

Faz-se necessário compreender a caracterização de cada elemento que compõe o AIO; tais definições serão apresentadas a seguir.

\subsection{Atitude}

"Atitude" em sua origem latina é composta pela combinação de dois termos, actus e aptitudo; o primeiro representa a ação ou o ato e o segundo, a aptidão. Ainda que usualmente se encontre a palavra representando o termo actus, ela encontra abrigo e utilização como aptidão.

De acordo com Rose (2008), o termo "Atitude" foi identificado, primeiramente, em uma publicação de "The Polish Peasant", em que Thomas e Znaniecki (1918) inicialmente propuseram que a "atitude" seria a internalização de um valor, sendo este valor algo sociamente aceito. Tal definição foi direcionada para grupos, o que fazia sentido, pois o tema de interesse abordado era o conflito entre imigrantes poloneses, nos Estados Unidos, grupos rurais poloneses e o Estadunidense das cidades (Fraser, 1994).Thurstone (1928, p.530) sugeriu que "a atitude denota a soma de todas as inclinações, sentimentos, vieses, noções de preconceito, ideias, ameaças, medos e convicções sobre um tópico específico”. Nesse contexto, a atitude se tornou um tema interessante, uma perspectiva para pensar e agir sobre os problemas das relações de indivíduos e grupos, parte da tentativa de desenvolver maneiras para o controle consciente da conduta social dos indivíduos baseado em conhecimento científico (Rose, 2008).

Após 1930, o termo atitude passou a não mais ser utilizado como visões de mundo de diferentes grupos e foi adotada uma perspectiva individual, ou seja, como indivíduos dentro de um grupo possuem visões diferentes (Rose, 2008). Tal visão já é apresentada na literatura por Allport (1935 p.799), que define atitude como: "um estado mental e neural de prontidão, organizado pela experiência que exerce influência diretiva ou dinâmica sobre a resposta do indivíduo sobre todos os objetos e situação com a qual está relacionado".

Atitudes, então, são formadas com base em "predisposições aprendidas a responder de uma maneira consistentemente favorável ou desfavorável a determinado objeto" (Fishbein \& Ajzen, 1975, p.175). Já para Heider (1967), atitude é uma relação positiva ou negativa entre indivíduos ou entre um indivíduo e um objeto, situação, evento ou ideia. Atitude é uma associação na memória entre um objeto de atitude e uma avaliação (Fazio, 1990), como uma 
tendência psicológica expressa por meio da avaliação de um indivíduo, com certo grau de favorabilidade ou desfavorabilidade (Eagly \& Chaiken, 1993) e aproximado de Gade (1998), que aponta a atitude como uma predisposição interna em um indivíduo no momento de fazer uma avaliação de um determinado objeto, ou aspecto.

Assim, como descrito por Ajzen (2001), é um consenso geral que a atitude representa um resumo da avaliação de um objeto em termos de bom ou ruim, benéfico ou prejudicial, agradável ou desagradável, e adorável ou detestável. Tomanari (2003) complementa afirmando que é uma avaliação apreendida por meio das experiências de um indivíduo, sendo favorável ou desfavorável a um determinado objeto, pessoa, grupo, ideia, organização ou evento que gera uma predisposição a agir em relação a esses fatores citados, de forma coerente com determinado valor social.

É apontado por Fishbein (1966) que as atitudes podem ser agrupadas em três grandes partes: cognitivo, afetivo e comportamental. O componente cognitivo diz respeito à representação mental do objeto, que se relaciona às crenças, aos conhecimentos e a outras informações e adjetivos a respeito dele. $\mathrm{O}$ componente afetivo é definido como o sentimento a favor ou contra um objeto. Já o componente comportamental refere-se à intenção de se agir perante o objeto, ou seja, à maneira que a pessoa espera ou deseja se comportar diante do objeto em questão.

Ainda, Gade (1998) reforça que a formação da atitude é um processo de aprendizado e que vem de um sistema de interação social em que as participações do indivíduo no grupo têm papel relevante. O indivíduo seleciona as atitudes que combinam com a satisfação das suas necessidades. Com base na perspectiva de condicionamento clássico, uma atitude é uma resposta emocional condicionada que pode ser trazida à tona com a ajuda de um estímulo condicionado (Mower \& Minor 2003).

Katz (1960) salienta que a atitude possui quatro funções:

a) Utilitária - maneira para maximizar uma ação, seja ela para maximizar benefícios, seja para minimizar prejuízos;

b) Defesa do ego - proteger um indivíduo de alguma verdade a seu respeito;

c) Conhecimento - compreender os fenômenos, integrando-os de forma coerente;

d) Expressão de valor - expressar de forma positiva seus valores ou autoconceito para a sociedade. 
Uma vez que a atitude é uma associação na memória entre um objeto de atitude e uma avaliação (Fazio, 1989), as atividades, os interesses e as opiniões da pessoa sofrem influência da atitude. A relação entre esses termos é apresentada na figura 3.

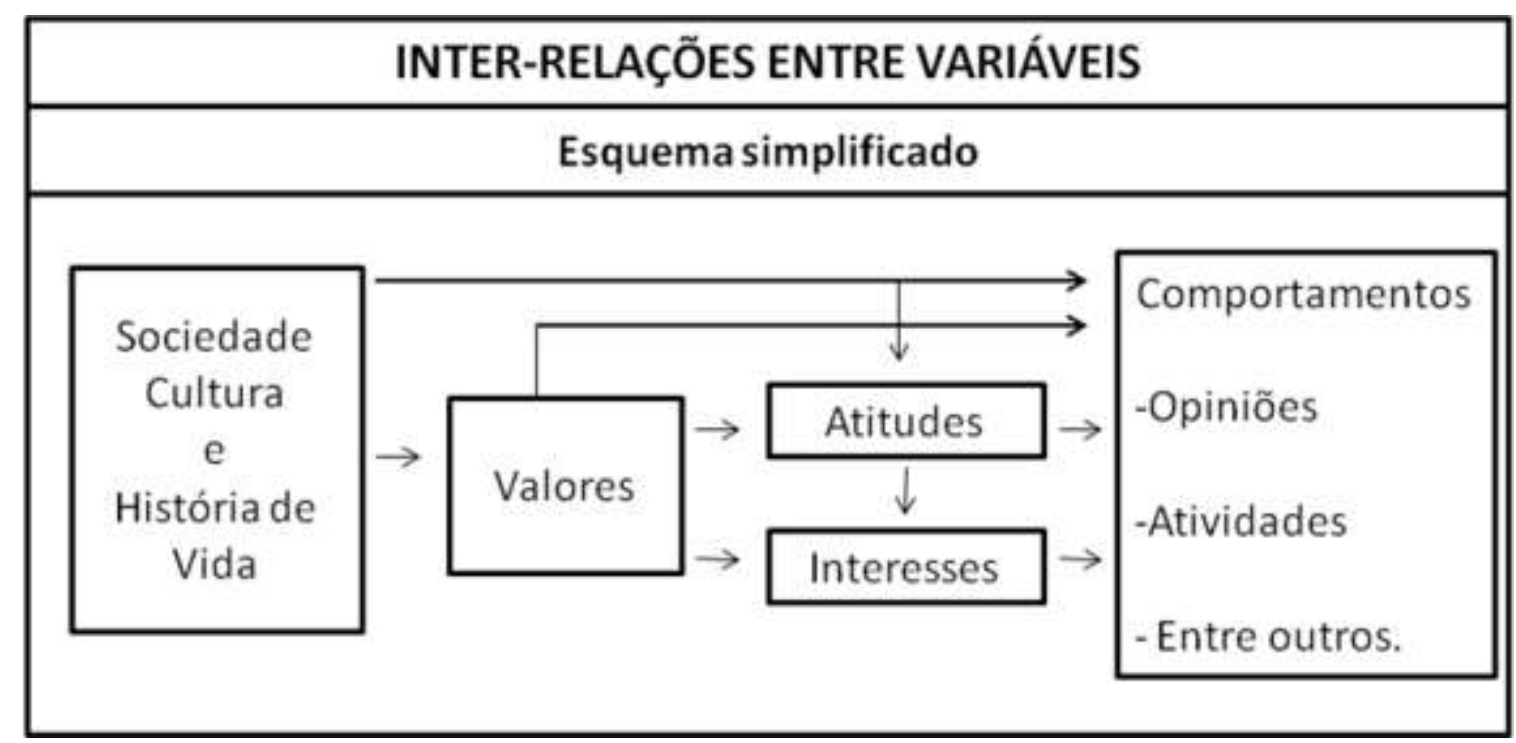

Figura 3. Inter-relações entre variáveis psicológicos

Fonte: Tomanari (2003)

Tomanari (2003) exemplifica a relação entre as variáveis do AIO com atitudes, relatando que a história de vida influencia os valores de um indivíduo, que, por sua vez, acaba influenciando as atitudes, os comportamento e interesses. Essas atitudes controlam os comportamentos e interesses que se relacionam com as atividades, além do comportamento. Os valores e as variáveis do AIO influenciam o consumidor na escolha de um produto e de uma marca. Essa escolha é feita de acordo com o que o indivíduo gosta de fazer e se o produto dessa marca vai atender sua necessidade como ele espera.

\subsection{Valores}

Valores são tratados desde Aristóteles, que apontou valores como "aquilo que todos desejam" e não como o que deveriam desejar, ou seja, é a concretização de uma natureza, pois o ser humano tem que realizar-se virtuosamente naquilo que lhe é natural, a sua razão, o modo pelo qual a pessoa "floresce", é ela mesma (Aristóteles, 2001). Porém, desde os seus primórdios já ocorrem divergências entre Sócrates, Platão e os Sofistas a respeito do significado da palavra valor. Os sofistas colocam o valor na subjetividade e na relatividade, traduzido pela ideia de que o homem é a "medida das coisas que são e das que não são" (Paulino, 2006, p.3). Assim, os valores ficam subordinados à apreciação humana. Em Sócrates, no entanto, o valor é objeto de um juízo de verdade, tendo assim validez universal. 
Platão, por sua vez, manifesta a ideia de que o Bem é o arquétipo supremo, a Forma das Formas, a realidade suprema para a qual todas as coisas devem direcionar-se.

Já, no contexto da sociedade moderna, Goergen (2005) aponta que Kant (17241804/2002) afirmava que o valor é a priorização de uma norma e que pode ou não ter realização prática, mas que confere verdade, bondade e beleza às coisas passíveis de escolha. A contribuição para a construção do significado de valor também encontra grande desenvolvimento na área da sociologia por intermédio de de Parsons (1937) que, inicialmente, já apresenta valores como um "subsistema integrador da sociedade onde os indivíduos, formulando um estado de laços no qual eles, de acordo com seus objetivos, se integram com o que é considerado desejável pela sociedade assim orientando suas ações dentro dela" (Parsons, 1937, p.254). Na área da antropologia, Kluckhohn (1951, p. 395) classifica valor como uma "concepção; explícita ou implícita, distintiva de um indivíduo ou característico de um grupo, do desejável que vai influenciar a seleção dentre os modos, meios e finalidades de ação disponíveis”. Kluckhohn e Strodtbeck (1961) também buscaram definir as dimensões que compõem o valor com base na resposta ou na forma de enfrentamento para os cinco tipos básicos de problema a serem resolvidos por toda a sociedade:

- Foco no passado, presente ou futuro;

- A relação entre a Humanidade e o seu ambiente natural, de domínio, submissão ou harmonia;

- Relacionamento dos indivíduos com os outros - hierarquicamente, como iguais, ou de acordo com seu mérito individual;

- Sua motivação para o comportamento, a expressão do eu, o crescimento pessoal, ou a busca por conquistas.

- Qual é a definição da natureza humana - boa, ruim ou um misto de ambas?

Kluckhohn e Strodtbeck (1961) procuraram descrever as possíveis respostas para cada um dos enfrentamentos, argumentando que a resposta prioritária em uma sociedade reflete sua orientação básica para aquele aspecto apresentado, as perguntas e possíveis respostas podem ser observadas na tabela abaixo: 
Tabela 3

Enfrentamentos de uma sociedade e suas respostas

\begin{tabular}{|c|c|c|}
\hline Questão & Orientação & Descrição \\
\hline \multirow{3}{*}{ Tempo } & Passado & $\begin{array}{l}\text { Nós focamos no passado (tempo anterior a esse) e na } \\
\text { preservação e manutenção dos ensinamentos e } \\
\text { crenças. }\end{array}$ \\
\hline & Presente & $\begin{array}{l}\text { Nós focamos no presente (o que é o agora) ajustando } \\
\text { mudanças em crenças e tradições. }\end{array}$ \\
\hline & Futuro & $\begin{array}{l}\text { Nós focamos no futuro (no tempo por vir) } \\
\text { planejando à frente e buscando novas maneiras de } \\
\text { substituir o que é antigo. }\end{array}$ \\
\hline \multirow{3}{*}{$\begin{array}{l}\text { Humanidade e seu } \\
\text { ambiente natural }\end{array}$} & Domínio & $\begin{array}{l}\text { Nós podemos e devemos exercitar controle total nas } \\
\text { forças da natureza e nas não naturais. }\end{array}$ \\
\hline & Submissão & $\begin{array}{l}\text { Nós não podemos e não devemos controlar as forças } \\
\text { da natureza pois elas estão subordinadas a "poderes } \\
\text { superiores". }\end{array}$ \\
\hline & Harmonia & $\begin{array}{l}\text { Nós podemos e devemos controlar parcialmente, } \\
\text { mas não totalmente as forças da natureza desde que } \\
\text { vivamos em equilíbrio com tais forças. }\end{array}$ \\
\hline \multirow{3}{*}{$\begin{array}{l}\text { Relacionamento dos } \\
\text { indivíduos com outros }\end{array}$} & $\begin{array}{l}\text { Hierárquico } \\
\text { (linear) }\end{array}$ & $\begin{array}{l}\text { Ênfase nos princípios hierárquicos e submissão a } \\
\text { maiores a autoridades ou autoridades dentro do } \\
\text { grupo. }\end{array}$ \\
\hline & $\begin{array}{l}\text { Como iguais } \\
\text { (lateral) }\end{array}$ & Ênfase na igualdade das pessoas e dos grupos. \\
\hline & Individualizado & $\begin{array}{l}\text { Ênfase no indivíduo ou grupos que tomam decisões } \\
\text { de modo independente dos outros. }\end{array}$ \\
\hline \multirow{5}{*}{$\begin{array}{l}\text { Motivação para o } \\
\text { comportamento }\end{array}$} & $\begin{array}{l}\text { Expressão do } \\
\text { "eu" }\end{array}$ & $\begin{array}{l}\text { A motivação é interna, enfatizando atividades } \\
\text { valorizadas pelo nosso "eu" e não necessariamente } \\
\text { por outros do grupo. }\end{array}$ \\
\hline & $\begin{array}{l}\text { Crescimento } \\
\text { pessoal }\end{array}$ & $\begin{array}{l}\text { Motivação para desenvolver habilidades que são } \\
\text { valorizadas por nós mas não necessariamente por } \\
\text { outros. }\end{array}$ \\
\hline & $\begin{array}{l}\text { Busca por } \\
\text { conquistas }\end{array}$ & $\begin{array}{l}\text { A motivação é externa, enfatizando atividades que } \\
\text { são valorizadas pelo indivíduo e são aprovadas por } \\
\text { outros no grupo. }\end{array}$ \\
\hline & $\begin{array}{l}\text { Crescimento } \\
\text { pessoal }\end{array}$ & $\begin{array}{l}\text { Motivação para desenvolver habilidades que são } \\
\text { valorizadas por nós mas não necessariamente por } \\
\text { outros. }\end{array}$ \\
\hline & $\begin{array}{l}\text { Busca por } \\
\text { conquistas }\end{array}$ & $\begin{array}{l}\text { A motivação é externa, enfatizando atividades que } \\
\text { são valorizadas pelo indivíduo e são aprovadas por } \\
\text { outros no grupo. }\end{array}$ \\
\hline
\end{tabular}

Nota: Fonte: Hills (2002) 
As definições contidas na tabela 2 sugerem que as prioridades de valores irão se diferenciar em função das alterações do ambiente, uma vez que as pessoas consideram que essa troca de prioridades representa a melhor maneira de se viver e expressar (Rohan, 2000). Na psicologia, Lewin (1942) contribui para a construção do conceito, apontando que valores influenciam o comportamento, mas não são objetivos em si. Por exemplo, o indivíduo não busca atingir o valor de "justiça”, porém a justiça guia o seu comportamento. É provavelmente correto dizer que valores determinam quais atividades possuem valência negativa ou positiva para um indivíduo em uma determinada situação. Allport (1955) reforça a ideia de que valores influenciam o comportamento, como sugerido por Lewin (1942), e também a percepção dos indivíduos, definindo valores como a crença na qual o homem se baseia para atuar por preferência, influenciando o modo como os indivíduos percebem a realidade.

Rokeach (1973), por sua vez, é o primeiro a classificar os valores objetivos de vida que um indivíduo possui e que guiam seus modos de conduta; para tanto, propôs a divisão dos valores em valores terminais, que seriam como um "estado final de existência", que estão ligados aos objetivos do indivíduo como ser humano; e os valores instrumentais, que estariam ligados à conduta ou ao comportamento de modo mais específico. Rokeach (1973) afirma que as pessoas usam seus valores aprendidos culturalmente para ajudar a racionalizar sobre atitudes e comportamentos que poderiam, de outra forma, ser pessoalmente ou socialmente inaceitáveis; são crenças situacionais hierarquicamente organizadas que servem para guiar o comportamento, são interiorizados no processo de socialização pela convergência das instituições sociais (e.g família, escola, amigos), constituem o núcleo da personalidade e são, portanto, a base do autoconceito. Já Feather (1995) descreve valores como estruturas abstratas que transcendem objetos específicos e situações específicas e são dotados de qualidade normativa e carregados de moral, influenciando escolhas e comportamentos pois são organizados de forma prioritária de acordo com a autoimagem.

Schwartz (1992) define os valores como critérios que são utilizados pelas pessoas para avaliar ações, pessoas e eventos. $\mathrm{O}$ autor propõe uma teoria que unifique outras teorias desenvolvidas no campo de motivações e comportamentos humanos, a fim de desenvolver um sistema universal de valores humanos, que contemple os principais valores compartilhados por todas as culturas (Blackwell, Miniard \& Engel, 2005, Schwartz, 2005). Para o autor, todas as pessoas possuem numerosos valores comuns, mas que variam em níveis de prioridade e importância de pessoa para pessoa. 
Segundo Schwartz (1992):

- Valores são crenças: valores são crenças intrínsecas ligadas à emoção e não a conceitos objetivos e frios. Quando os valores são ameaçados ou ativados, sentimentos positivos e negativos são gerados. Quando um valor (e.g. autoridade, reconhecimento social ou prazer) é ameaçado, a pessoa que endossa este valor, inconscientemente, entra em estado de alerta e defesa.

- Valores são um construto motivacional: valores fornecem uma motivação e uma orientação para as pessoas agirem de forma adequada, referem-se a objetivos que as pessoas desejam alcançar (e.g. sucesso, saúde, justiça).

- Valores transcendem situações e ações específicas: ao contrário de normas, valores, como obediência, independência, honestidade, transcendem situações específicas e orientam as pessoas em diversos contextos de suas vidas, como nos esportes, no trabalho, nos estudos, nos relacionamentos, entre outros.

- Valores guiam a seleção e a avaliação de ações, políticas, pessoas e eventos: como dito anteriormente, os valores são critérios por meio dos quais os indivíduos decidem se eventos, pessoas, ações e políticas são aceitáveis ou reprováveis, bons ou maus, justificados ou ilegítimos, se merecem aproximação ou refutação, na medida em que essas ações, políticas e pessoas são congruentes ou possam ameaçar os valores endossados por cada pessoa.

- Valores são ordenados: os valores de cada pessoa formam um sistema ordenado de prioridades.

As características acima são comuns a todos os valores, porém na teoria de valores de Schwartz (2005) o pesquisador define dez tipos motivacionais individuais distintos, de acordo com as motivações e objetivos gerados por cada um desses valores (Schwartz, 2005). Schwartz e Bilsky (1987) apontaram que os valores derivam de três tipos de necessidades humanas básicas: "universais: necessidades biológicas do organismo; necessidade de interação social para a manutenção das relações interpessoais; e necessidades socioinstitucionais, que buscam o bem-estar e a sobrevivência do grupo" (Schwartz \& Bilsky, 1987, p.551). A teoria presume que estes tipos motivacionais são universais por agruparem os valores mais básicos e importantes reconhecidos por todas as culturas (Schwartz, 2005).

A tabela abaixo descreve os dez tipos motivacionais contemplados na Teoria de Valores de Schwartz, suas metas e como são compostos em termos de valores: 
Tabela 4

Relação dos Valores Humanos de Schwartz

\begin{tabular}{|c|c|c|}
\hline $\begin{array}{c}\text { Tipo } \\
\text { Motivacional }\end{array}$ & Objetivo ou Meta & Exemplo de Valores \\
\hline Autodeterminação & $\begin{array}{l}\text { Pensamento e ação independente, } \\
\text { escolher, criar, explorar }\end{array}$ & $\begin{array}{l}\text { Criatividade, liberdade, escolha do } \\
\text { próprio destino, } \\
\text { independência, } \\
\text { privacidade. }\end{array}$ \\
\hline Estimulação & $\begin{array}{l}\text { Excitação, novidade, desafio na } \\
\text { vida. }\end{array}$ & $\begin{array}{l}\text { Uma vida diversificada, uma vida } \\
\text { excitante, ousadia }\end{array}$ \\
\hline & Prazer ou gratificação sexual. & \\
\hline Hedonismo & $\begin{array}{l}\text { Valores de hedonismo são } \\
\text { derivados de necessidades } \\
\text { orgânicas e do prazer associado à } \\
\text { sua satisfação. }\end{array}$ & $\begin{array}{l}\text { Prazer, vida } \\
\text { autoindulgência. }\end{array}$ \\
\hline Realização & $\begin{array}{l}\text { Sucesso pessoal por meio de } \\
\text { demonstração de competência de } \\
\text { acordo com padrões sociais }\end{array}$ & $\begin{array}{l}\text { Ambição, sucesso, capacidade de } \\
\text { influência, } \\
\text { reconhecimento social. }\end{array}$ \\
\hline Poder & $\begin{array}{l}\text { Status social e prestígio, controle } \\
\text { ou domínio sobre pessoas e } \\
\text { recursos. }\end{array}$ & $\begin{array}{l}\text { Autoridade, saúde, podersocial, } \\
\text { preservação da imagem pública, } \\
\text { reconhecimento social. }\end{array}$ \\
\hline Segurança & $\begin{array}{l}\text { Segurança, harmonia e } \\
\text { estabilidade da sociedade, dos } \\
\text { relacionamentos e de si mesmo. }\end{array}$ & $\begin{array}{l}\text { Ordem social, segurança familiar, } \\
\text { segurança nacional, reciprocidade de } \\
\text { favores, limpeza, saúde e senso de } \\
\text { pertencimento. }\end{array}$ \\
\hline Conformidade & $\begin{array}{l}\text { Restrição de ações, inclinações e } \\
\text { impulsos que tendem a chatear ou } \\
\text { prejudicar outros e que violam } \\
\text { expectativas ou normas sociais. }\end{array}$ & $\begin{array}{l}\text { Obediência, autodisciplina, educação, } \\
\text { respeito aos parentes e mais velhos. }\end{array}$ \\
\hline Tradição & $\begin{array}{l}\text { Respeito, compromisso e } \\
\text { aceitação dos costumes e ideias } \\
\text { que a cultura ou a religião do } \\
\text { indivíduo fornecem. }\end{array}$ & $\begin{array}{l}\text { Respeito a tradições, humildade, } \\
\text { devoção, aceitação da vida que possui, } \\
\text { moderação. }\end{array}$ \\
\hline Benevolência & $\begin{array}{l}\text { Preservar e fortalecer o bem estar } \\
\text { daqueles com quem o contato } \\
\text { pessoal do indivíduo é mais } \\
\text { frequente (endogrupo). }\end{array}$ & $\begin{array}{l}\text { Lealdade, colaboração, perdão, } \\
\text { honestidade, responsabilidade, amizade } \\
\text { verdadeira, amor maduro. }\end{array}$ \\
\hline Universalismo & $\begin{array}{l}\text { Compreensão, agradecimento, } \\
\text { tolerância e proteção do bem } \\
\text { estar de todas as pessoas e da } \\
\text { natureza. }\end{array}$ & $\begin{array}{l}\text { Mente aberta, justiça social, igualdade, } \\
\text { mundo em paz, munde de beleza, } \\
\text { unidade com a natureza, sabedoria, } \\
\text { proteção ao meio ambiente }\end{array}$ \\
\hline
\end{tabular}

Nota. Fonte: Silva (2007)

Para Schwartz (1992), estes tipos motivacionais estão organizados em diferentes sistemas psicológicos de semelhanças e opostos que formam um continuum ou hierarquia de 
motivações. Esse continuum motivacional estrutura-se em duas dimensões básicas, denominadas dimensões de ordem superior (Mendonça \& Tamayo, 2008). Apesar de a teoria agrupar e distinguir os valores em dez tipos motivacionais, Schwartz (2005) afirma que, em nível mais básico, os valores formam um continuum de motivações relacionadas (Blackwell, Miniard \& Engel, 2005; Schwartz, 2005). Isso se deve ao fato de que algumas ações, que são congruentes com algum valor e seu tipo motivacional, acarretam consequências que podem ser complementares e congruentes, ou conflitantes, com os objetivos de outros tipos motivacionais que estejam próximos ou opostos (Schwartz, 2005). Por exemplo, a busca por realização tende a ter ações coerentes com poder e conflitantes com benevolência e universalismo.

Schwartz et al. (2012) propõem um refinamento da teoria dos Valores Humanos argumentando que os dez tipos motivacionais apresentados na teoria original emergiram de uma estrutura básica presente em todas as sociedades, derivada de três características universais de todos os seres humanos, as necessidades biológicas do ser humano como organismo vivo, necessidade de interação e coordenação social e bem-estar e sobrevivência de grupos. Cada um dos Valores Humanos é alicerçado por um ou mais desses três princípios (Schwartz, 1992). Schwartz et al. (2012) argumentam que a divisão anterior de Schwartz (1992) era arbitrária, e que, após 20 anos, o autor decide propor uma divisão mais clara dos tipos motivacionais para 19 tipos motivacionais mais bem descritos.

Schwartz et al. (2012) argumentam que os Valores Humanos são apresentados em um continuum ou, como descrito por Davidov, Schmidt e Schwartz (2008, p.424): “a organização circular dos valores representa um continuum de motivações correlacionadas, como uma palheta contínua de cores e não um set organizado de modo discreto e independente". Assim como Schwartz (1992, p. 45-46) aponta, "as diferenças entre os valores são contínuas e a partição entre elas é arbitrária"; logo, a apresentação dos Valores Humanos em um contínuo com mais partições emergiu também da ocorrência de estudos como os de Caprara, Schwartz, Capanna Vecchione e Barbaraneli (2006), que dividiram a autodeterminação em autodeterminação de ação e pensamento e encontraram alta correlação da autodeterminação de pensamento e não de ação com o fator de abertura da escala dos cinco grandes fatores de personalidade (Big Five). Schwartz et al. (2012) propuseram então uma subdivisão dos 10 tipos motivacionais utilizando os componentes de suas definições, com a criação de dois outros tipos, resultando em 19 subtipos. A apresentação dos 10 tipos motivacionais, sua definição conceitual e seus componentes é apresentada na tabela 5 a seguir. 


\section{Tabela 5}

Definição conceitual dos 10 tipos motivacionais de acordo com seus objetivos e definições que sugerem subtipos motivacionais

\begin{tabular}{|c|c|c|}
\hline $\begin{array}{l}\text { Valores } \\
\text { Humanos }\end{array}$ & Definição Conceitual & Componentes da definição \\
\hline Auto-direção & $\begin{array}{l}\text { Independência de ação e pensamento, escolha, } \\
\text { criação, exploração }\end{array}$ & $\begin{array}{l}\text { Autonomia de pensamento } \\
\text { Autonomia de ação }\end{array}$ \\
\hline Estimulação & Excitação, inovação e desafios na vida & $\begin{array}{l}\text { Excitação } \\
\text { Novidade } \\
\text { Desafio }\end{array}$ \\
\hline Hedonismo & Gratificação e prazer sensorial & Prazer \\
\hline Realização & $\begin{array}{l}\text { Sucesso pessoal através da demonstração de } \\
\text { competência de acordo com padrões sociais }\end{array}$ & $\begin{array}{l}\text { Sucesso pessoal } \\
\text { Demonstração de competência }\end{array}$ \\
\hline Poder & $\begin{array}{l}\text { Status social e prestígio, controle ou domínio sobre } \\
\text { pessoas e recursos }\end{array}$ & $\begin{array}{l}\text { Dominação de pessoas } \\
\text { Controle de recursos materiais } \\
\text { Face: Status e prestígio }\end{array}$ \\
\hline Segurança & $\begin{array}{l}\text { Segurança, harmonia, estabilidade da sociedade, de } \\
\text { relacionamentos e pessoal }\end{array}$ & $\begin{array}{l}\text { Segurança social } \\
\text { Seguraça pessoal }\end{array}$ \\
\hline Conformidade & $\begin{array}{l}\text { Restrição de ações, inclinações e impulsos que } \\
\text { possam irritar ou ferir outros e violar as expectativas e } \\
\text { normas sociais }\end{array}$ & $\begin{array}{ll}\text { Interpessoal: } & \text { Evitar } \\
\text { incomodar outros } & \\
\text { Cumprimento das normas } \\
\text { sociais }\end{array}$ \\
\hline Tradição & $\begin{array}{l}\text { Respeito, comprometimento e aceitação dos padrões e } \\
\text { idéias que a cultura tradicional e religão conferem }\end{array}$ & $\begin{array}{l}\text { Manter tradições culturais e } \\
\text { religiosas }\end{array}$ \\
\hline Benevolência & $\begin{array}{l}\text { Preservação e melhora do bem estar das pessoas as } \\
\text { quais o indivíduo está em contato pessoal }\end{array}$ & $\begin{array}{l}\text { Preocupação com membros } \\
\text { do grupo }\end{array}$ \\
\hline Universalismo & $\begin{array}{l}\text { Entendimento, apreciação, tolerância e proteção do } \\
\text { bem estar de todas as pessoas e da natureza }\end{array}$ & $\begin{array}{l}\text { Tolerância } \\
\text { Preocupação social } \\
\text { Proteção da natureza }\end{array}$ \\
\hline
\end{tabular}

Nota. Fonte: Adaptado de Schwartz et al. (2012)

Schwartz et at. (2012) argumentam que a subdivisão nos tipos motivacionais leva à refinada heurística universal e ao maior poder preditivo, resultando em 19 tipos motivacionais melhor caracterizados, compatíveis com a teoria dos 10 valores inicialmente proposta por Schwartz (1992). A teoria refinada dos Valores Humanos utiliza um continuum motivacional como a dos 10 tipos motivacionais, de forma que sua estrutura circular permita recapturar a mesma estrutura universal original proposta por Schwartz (1992). A figura 4 demonstra a estrutura circular da teoria refinada de valores de Schwartz et al. (2012): 


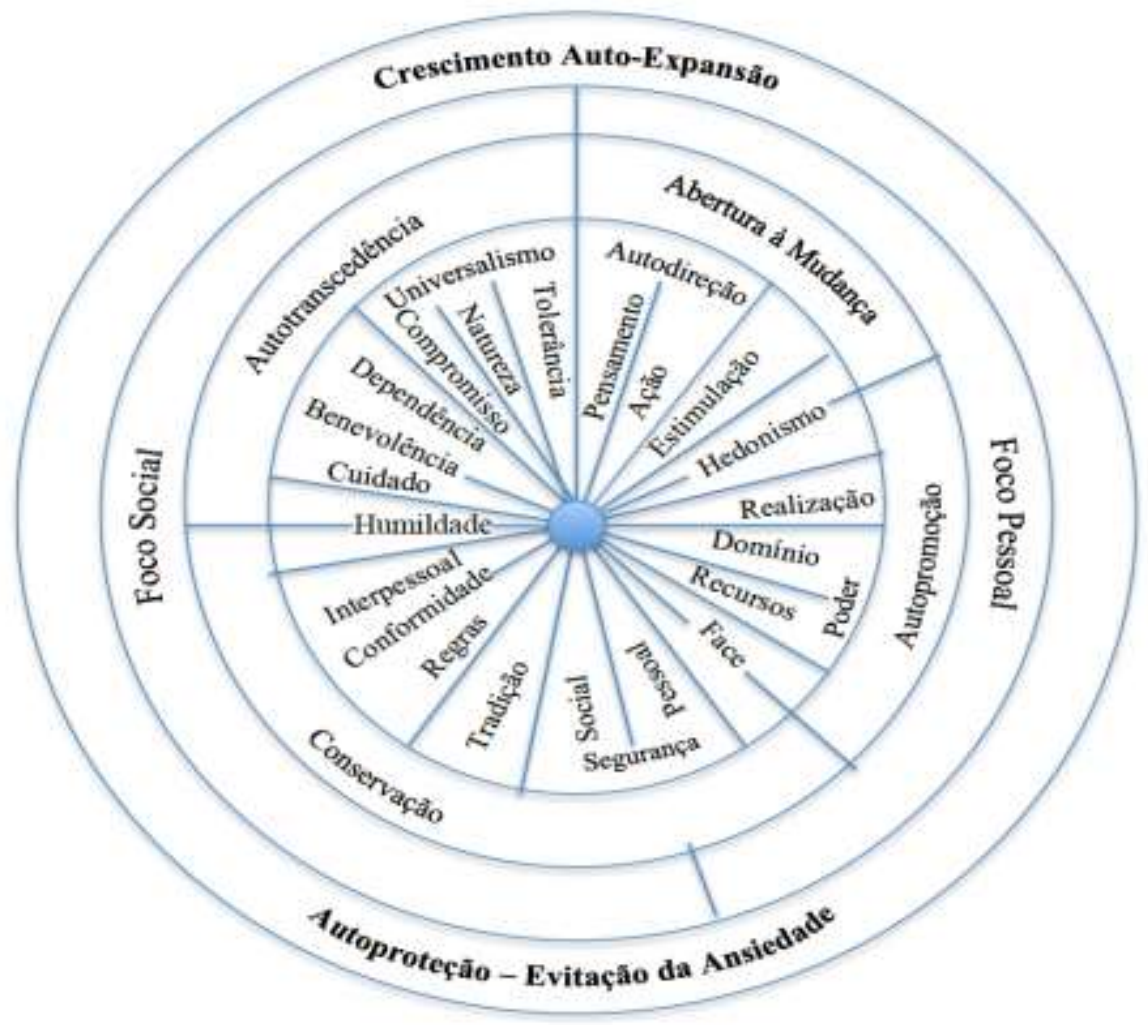

Figura 4. Continuum dos valores refinados de Schwartz Fonte: Adaptado de Schwartz et al. (2012)

Por fim, uma organização cronológica das diferentes definições de valores é apresentada conforme a tabela 6 :

Tabela 6

Definições de valores

Subsistema integrador da sociedade em que o indivíduo, formula um estado de laços no qual os indivíduos da sociedade, de

Talcott Parsons 1937 acordo com seus objetivos, se integram com o que é considerado desejável pela sociedade assim orientando suas ações dentro dela.

Kurt Lewin

Valores influenciam o comportamento, mas não são objetivos em si Por exemplo, o indivíduo não busca atingir o valor de "justiça", porém justiça guia o seu comportamento. É provavelmente correto dizer que valores determinam quais

1942 atividades possuem valência negativa ou positiva para um indivíduo, em uma determinada situação. Em outras palavras, valores não são campos de força, mas induzem campos de força. Isso significa que valores são construtos que possuem a mesma dimensão psicológica que campos de força lewinianos. 


\begin{tabular}{lrl}
$\begin{array}{l}\text { Clyde Kay Maben } \\
\text { Kluckholm }\end{array}$ & 1951 & $\begin{array}{l}\text { O valor é uma concepção, explícita ou implícita, distintiva de } \\
\text { um indivíduo ou um grupo, do desejável que influencia a seleção } \\
\text { de modos, meios e fins de ações disponíveis. }\end{array}$ \\
\hline Gordon Allport & $1955 \begin{array}{l}\text { Os valores constituem uma crença, na qual o homem se baseia } \\
\text { para atuar por preferência, que influencia o modo como os } \\
\text { indivíduos percebem a realidade }\end{array}$ \\
\hline Milton Rokeach & $1973 \begin{array}{l}\text { Os valores são uma crença duradoura, na qual o modo específico } \\
\text { de conduta ou estado final de existência é pessoal, ou ainda, } \\
\text { socialmente preferível a um outro modo de conduta. }\end{array}$ \\
\hline Shalom Schwartz 1992 & $\begin{array}{l}\text { Valores são objetivos desejáveis transituacionais, que variam em } \\
\text { importância e que servem como guia de princípios na vida de } \\
\text { uma pessoa ou uma entidade social. }\end{array}$ \\
\hline Norman Feather & $1996 \begin{array}{l}\text { Valores são maneiras desejáveis ou indesejáveis de se comportar } \\
\text { ou considerados como desejabilidade ou oposição a objetivos } \\
\text { gerais. }\end{array}$ \\
\hline Meg Rohan & $2000 \begin{array}{l}\text { Os valores são constituídos com base nos julgamentos sobre a } \\
\text { capacidade de coisas, pessoas, ações e atividades, que levam as } \\
\text { pessoas a viverem da melhor forma possível. }\end{array}$ \\
\hline
\end{tabular}

Nota. Fonte: $\mathrm{O}$ autor

Como os valores variam de pessoa para pessoa, de país para país e de cultura para cultura (De Mooij, 2003), uma análise detalhada dos valores defendidos por determinada cultura pode vir a demonstrar que certa abordagem de posicionamento do produto, ou até mesmo o próprio produto, são totalmente inadequados para a cultura em questão ou para um grupo de indivíduos, por entrar em conflitos com seus valores (De Mooij, 2003; Lindquist \& Sirgy, 2006). É relevante para estudos do comportamento do consumidor que os valores possam determinar que tipos de benefícios os consumidores vão procurar nos produtos que compram (Lindquist \& Sirgy, 2006). Assim, torna-se fundamental para as empresas entender e conhecer a fundo quais são os valores endossados e aprovados pelos clientes de cada segmento de mercado atendido pela empresa (De Mooij, 2003). Uma análise destes valores pode levar uma empresa a mudar o segmento de mercado que atende, recriar suas propagandas e reposicionar seus produtos no mercado, comunicando de forma mais eficaz os valores realmente importantes para seus clientes, e, até mesmo, desistir de entrar em um país ou em uma cultura nova (De Mooij, 2003; Blackwell, Miniard \& Engel, 2005; Lindquist \& Sirgy, 2006; Solomon, 2002.

Em virtude do papel que exercem nas atitudes, decisões e comportamentos dos consumidores, os valores pessoais se tornam foco de estudo de alta importância por parte dos departamentos de marketing das empresas (Lindquist \& Sirgy, 2006; Solomon, 2002). Os valores determinam aquilo que será importante, preferível e aceitável para uma pessoa, em detrimento de outras opções (De Mooij, 2003; Lindquist \& Sirgy, 2006; Solomon, 2002). 
Desta forma, os valores poderão influenciar profundamente a forma como uma pessoa irá passar seu tempo, gastar seu dinheiro e investir seus recursos (De Mooij, 2003; Blackwell, Miniard \& Engel, 2005; Lindquist \& Sirgy, 2006; Solomon, 2002). Portanto, os valores podem contribuir para o entendimento de como as gerações se diferenciam e se caracterizam. Schwartz (2005) observou que existem três fatores preponderantes em adultos, que determinam a mudança de valores: eventos históricos impactantes, envelhecimento e fase da vida. Assim, é natural que os benefícios procurados em produtos variem em função das gerações de idade. visto que o presente estudo utiliza como um dos elementos delineadores das características de gerações os seus valores humanos básicos, fundamentais paradescrever as diferentes maneiras de se medir valores, a serem apresentados na próxima sessão.

\subsubsection{Medidas de Valores}

\subsubsection{RVS (Rokeach Value Survey)}

O psicólogo Milton Rokeach desenvolveu uma das maneiras mais conhecidas de definir e mensurar valores, chamada Escala de Valores Pessoais de Rokeach (1973). Como dito anteriormente, Rokeach (1973) definiu os valores como crenças de que determinados comportamentos específicos e certos estados finais de existência são preferíveis em detrimento de outros.

Assim, Rokeach (1973) desenvolveu uma escala de Valores (formas específicas de conduta e comportamento preferíveis e aceitáveis), que, sendo ativados ao longo do tempo, irão levar a estados finais desejados, chamados de Valores Terminais. A escala de Rokeach (1973), denominada RVS (Rokeach Value Survey), consiste numa ferramenta com duas listas de dezoito valores cada, sendo uma de valores Instrumentais e outra de valores Terminais. Segundo esse autor, um critério importante utilizado na escolha dos trinta e seis valores da RVS diz respeito à sua compreensão razoável e à sua aplicabilidade universal. Na sua forma tradicional, o RVS requer que o sujeito classifique os valores por posto (ranking), segundo a ordem de importância de cada um dos dois conjuntos de valores (Terminais e Instrumentais) em termos das prioridades do respondente.

Tamayo (2007) aponta que o primeiro instrumento de valores foi o de Rokeach (1973), traduzido e testado no Brasil por Günther (1981), chamado de IVR (Inventário de Valores de Rokeach), cuja divisão entre valores terminais e instrumentais não encontra fundamento empírico. Este fato é corroborado por Silva (2007), que afirma que, apesar de esta divisão de valores feita por Rokeach (Valores Instrumentais e Terminais) ser lógica, não encontrou embasamento empírico, devido ao modo intuitivo pelo qual o psicólogo 
desenvolveu esta lista (Silva, 2007). Isto significa que valores importantes podem ter sido omitidos, comprometendo assim sua validade científica (Silva, 2007).

A tabela 7 lista diversos exemplos de Valores Instrumentais e Terminais, de acordo com a pesquisa realizada por Rokeach (1973) nos Estados Unidos:

Tabela 7

Relação dos Valores Humanos de Rokeach

\begin{tabular}{|c|c|}
\hline Valores Terminais & Valores Instrumentais \\
\hline Uma vida confortável (uma vida próspera) & Ambição (esforço no trabalho, vontade) \\
\hline Uma vida emocionante (ativa, estimulante) & Visão Ampla (mente aberta) \\
\hline $\begin{array}{l}\text { Um sentido de realização (contribuição } \\
\text { duradoura) }\end{array}$ & Capacidade (competência, eficácia). \\
\hline $\begin{array}{l}\text { Um mundo em paz (livre de guerra ou } \\
\text { conflitos) }\end{array}$ & Animação (alegria, contentamento). \\
\hline $\begin{array}{l}\text { Um mundo de beleza (beleza da natureza e } \\
\text { das artes) }\end{array}$ & Limpeza (asseio, arrumação). \\
\hline $\begin{array}{l}\text { Igualdade (fraternidade, oportunidade igual } \\
\text { para todos) }\end{array}$ & Coragem (defesa de seus ideais). \\
\hline $\begin{array}{l}\text { Segurança familiar (cuidado com os entes } \\
\text { queridos) }\end{array}$ & $\begin{array}{l}\text { Perdão (capacidade de perdoar os } \\
\text { outros). }\end{array}$ \\
\hline $\begin{array}{l}\text { Liberdade (independência, liberdade de } \\
\text { escolha) }\end{array}$ & $\begin{array}{l}\text { Ser Prestativo (trabalhar pelo bem-estar } \\
\text { dos demais). }\end{array}$ \\
\hline Felicidade (contentamento) & $\begin{array}{l}\text { Honestidade } \\
\text { verdadeiro). }\end{array}$ \\
\hline $\begin{array}{l}\begin{array}{l}\text { Harmonia } \\
\text { interiores) }\end{array} \\
\text { y liberação }\end{array}$ & Imaginação (ousadia, criatividade). \\
\hline $\begin{array}{l}\text { Amor Maduro (intimidade espiritual e } \\
\text { sexual) }\end{array}$ & $\begin{array}{l}\text { Independência } \\
\text { autossuficiência). }\end{array}$ \\
\hline $\begin{array}{l}\text { Segurança Nacional (proteção contra } \\
\text { ataques) }\end{array}$ & $\begin{array}{l}\text { Intelectualidade } \\
\text { capacidade de reflexão). }\end{array}$ \\
\hline Prazer (uma vida com alegria e lazer) & Lógica (coerência, racionalidade) \\
\hline Salvação (salvaguarda, vida eterna) & Afetividade (carinho, ternura). \\
\hline Respeito por si próprio (autoestima) & $\begin{array}{l}\text { Obediência (ser respeitável, cumpridor } \\
\text { dos deveres). }\end{array}$ \\
\hline $\begin{array}{l}\text { Reconhecimento } \\
\text { admiração) }\end{array}$ & Polidez (cortesia, boas maneiras). \\
\hline $\begin{array}{l}\text { Amizade verdadeira } \\
\text { companheirismo) }\end{array}$ & $\begin{array}{l}\text { Responsabilidade (compromisso, } \\
\text { confiável). }\end{array}$ \\
\hline Sabedoria (compreensão madura da vida) & Autocontrole (limites, autodisciplina). \\
\hline
\end{tabular}

Nota. Fonte: Traduzido de Rokeach (1973, p.28) 
Tamayo (2007) aponta que o IVR encontra pouca representatividade nos valores humanos, e é questionado desde seu método concepção até sua estrutura de aplicação. Tais afirmações desestimulam sua utilização, no Brasil, fazendo-se assim necessário estudar outras medidas de valores que se demonstrem mais satisfatórias como o SVS (Schwartz Value Survey), PQ (Portraits Questionnaire) e LOV (List of Values). Tais medidas são apresentadas a seguir.

\subsubsection{LOV (List of Values)}

LOV é um instrumento de pesquisa que apenas inclui valores terminais de Rokeach (1973) e da teoria da hierarquia de valores de Maslow (1987): a Lista de Valores (List of Values - LOV). Desenvolvida na University of Michigan Survey Research Center (Kahle, Beatty \& Homer,1986; McIntyre et al, 1994), a escala LOV foi utilizada, pela primeira vez, em uma pesquisa feita com uma amostra probabilística de respondentes dos Estados Unidos, em 1976, tendo cada pesquisado indicado seu valor mais importante baseado em uma lista de nove (Kahle \& Kennedy, 1998). Diferente da escala RVS, a LOV é um instrumento de pesquisa abreviado que apenas inclui valores terminais, mostrando evidências de que o relacionamento dos valores dos consumidores com seus comportamentos estão num nível mais abstrato do que os dos valores instrumentais (Kamakura \& Novak, 1992). A LOV provê uma solução para o problema de elaborar um ranking de 18 valores, como é necessário para a RVS. Na escala LOV, uma lista reduzida de nove valores terminais é utilizada, simplificando bastante o processo de preenchimento de um questionário. Dois itens da LOV (valores terminais de "realização" e "respeito próprio") são idênticos aos itens da RVS, enquanto os demais combinam diversos itens da RVS ou generalizam seus itens especificamente (Kamakura \& Novak, 1992).

De acordo com Soutar, Grainger e Hedges (1999), o modelo de Kahle (1983) apresenta vantagens sobre o RVS (Rokeach Value Survey) para a medição de valores dos indivíduos pois:

a) É derivado da lista de valores instrumentais e terminais de Rokeach (1973); o modelo de Kahle (1983) é simplificado e mais fácil de ser operacionalizado, permitindo ao respondente focalizar-se em suas situações cotidianas;

b) $\mathrm{O}$ menor tempo para o preenchimento e a flexibilidade em relação à escala de Rokeach (1973) permite estabelecer ordenamento, graduação e seleção de procedimentos por parte do respondente; 
c) Apresenta maior brevidade e simplicidade no preenchimento, sendo mais facilmente transferível para outras culturas do que o modelo de Rokeach (1973)

d) Do ponto de vista operacional, o estudo de Kahle (1983) consiste em dispor os valores terminais do modelo de Rokeach em uma lista de nove variáveis, essencialmente orientadas à pessoa, em oposição à orientação dos valores do instrumento de Rokeach, de conotação social.

A praticidade, a abrangência sobre crenças da vida cotidiana e, sobretudo, por não conter conceitos considerados especificamente ocidentais, permite ao pesquisador aplicar o LOV em diversos contextos nacionais e culturais, diferenciando-se de instrumentos similares de medição de valores (Kahle, Rose \& Shoham 2000).Os itens constantes na Lista de Valores original são os seguintes (Kahle \& Kennedy, 1998):
1. Pertencer a um grupo
2. Excitação
3. Relações amigáveis
4. Satisfação pessoal
5. Ser bem respeitado
6. Diversão e prazer na vida
7. Segurança
8. Amor próprio
9. Realização pessoal

Os valores propostos na LOV têm demonstrado maior alinhamento com as pesquisas de comportamento do consumidor e a relação mais direta para aplicações de marketing (Kahle, Beatty \& Homer 1986; Kamakura \& Novak, 1992), sendo, assim, mais indicado para a presente pesquisa. A próxima sessão dedica-se a descrever a LOV.

\subsubsection{SVS (Schwartz Value Survey) e PVQ (Portrait Values Questionnaire)}

De acordo com Bilsky (2009), a escala de valores de Rokeach (1973) foi estudada para investigar sua estrutura de valores e apresentou-se insuficiente com respeito à diversidade de valores (Schwartz \& Bilsky, 1987, 1990; Bilsky \& Schwartz, 1994). Assim, Schwartz (1992) delineou um instrumento novo, a escala de valores de Schwartz (SVS), com 54 itens. Esse instrumento baseia-se no RVS, porém, completando-o nos setores nos quais o RVS se mostrou insuficiente. Além disso, foi desenvolvida uma forma de resposta mais diferenciada para avaliar os itens de valores individuais, em que o respondente deveria estimar cada valor, utilizando uma escala de 9 pontos, como "um princípio guia em minha 
vida". O autor empregou frases explicativas substantivas entre parênteses para facilitar a compreensão dos valores que estava medindo (Bilsky, 2009).

Smith e Bond (1999) apontam que para identificar a estrutura dos valores humanos Schwartz (1992) utilizou o procedimento estatístico chamado SSA (Smallest Space Analysis), que aloca a média para cada item em um espaço multidimensional e a distância estatística entre eles é a medida de sua proximidade psicológica; esse procedimento identifica quais itens se aglutinam, porém não fornece informações sobre quais valores são mais importantes em cada cultura. Schwartz (1992) apresenta análises de 32 amostras em vinte países e salienta a consistência de seu modelo. Sagiv e Schwartz (1995) estendem a análise de Schwartz (1992) para 88 amostras de 40 países e encontram as mesmas relações entre os valores estudados, validando seus pressupostos teóricos.

No Brasil, Tamayo e Schwartz (1993) realizaram a tradução e a validação do SVS, chamado também de IVS, utilizando um dos métodos indicados por Rokeach (1979) para identificar valores de uma sociedade. Tamayo (2007) realizou entrevistas individuais com 20 professores de escola, sacerdotes e ministros religiosos. Foram detectados por meio das entrevistas quatro valores que parecem ser característicos da cultura brasileira (Tamayo \& Schwartz, 1993). Estes valores foram agregados ao SVS antes de se proceder à sua validação. Desta forma, o instrumento utilizado no Brasil compreende valores transculturais e valores brasileiros, organizados em 10 tipos motivacionais (Tamayo, 2007).

Bilsky (2009) explica a respeito do SVS, que existe desvantagem no nível de abstração que, pressupõe-se, tenha o participante. Por isso, não se pode empregar o SVS em amostras intelectualmente muito variadas. Em função disso, foi desenvolvida outra medida para investigar valores: o perfil de valores pessoais - PVQ (Schwartz et al., 2001). Campos e Porto (2010) apontam que o PVQ foi criado com o intuito de verificar valores em culturas diferentes, ressaltando sua funcionalidade em respondentes com nível de escolaridade baixo, devido à sua simplicidade. Bilsky (2009) descreve que no PVQ a tarefa do respondente é comparar-se com outras pessoas de mesmo sexo. Essas pessoas são descritas mediante breves vinhetas, cada uma delas enfatizando uma orientação valorativa específica, de acordo com a teoria dos valores (Bilsky, 2009).

A primeira versão brasileira possui somente frases no feminino e contém 40 afirmações em que se descrevem pessoas com metas, interesses e aspirações diferentes, considerando os dez tipos motivacionais como "Pensar em novas ideias e ser criativa é importante para ela. Ela gosta de fazer coisas de maneira própria e original”. Para 
compararem-se com essa pessoa, os indivíduos utilizam uma escala de seis pontos, variando entre "Parece-se muito comigo" a "Não se parece nada comigo" (Bilsky, 2009). Campos e Porto (2010) ainda mostram que essa escala foi desenvolvida originalmente em inglês e foi utilizado o processo de tradução para o português e retradução (Brislin, 1970) para o inglês, a fim de garantir a compatibilidade entre as versões. A segunda versão brasileira, o Perfil de Valores de Schwartz (PQ-21), é composta por vinte e um itens, que descrevem objetivos, aspirações ou desejos que, implicitamente, apontam para a importância de um tipo motivacional em uma pessoa. Tal escala, validada no Brasil, é de mais fácil aplicação, o que aumenta a probabilidade da taxa de respostas, diminuindo o risco de missing e de mortalidade de participantes (Porto \& Campos, 2007).

Schwartz et al (2001) apontam que tanto o SVS quanto o PVQ apresentam razoável confiabilidade para se medir os 10 valores que descrevem que estudos em amostras iguais não alteraram a hierarquia dos valores com diferentes instrumentos (Schwartz et al, 2001). Em resumo, a apresentação do PVQ é uma apresentação mais simples em que o respondente se compara ao sujeito descrito na frase (que reflete um tipo motivacional). Este resultado sofre ajuste na própria análise dos dados, enquanto o SVS oferece uma estrutura diversa com valores negativos e positivos em que o entrevistado se reporta diretamente ao entrevistador.

\subsubsection{PVQ-R (Portraits Values Questionnaire Revised)}

Schwartz et al. (2012) propuseram a subdivisão dos dez tipos motivacionais apresentados por Schwartz (1992) em dezenove subtipos compostos pelas definições dos dez tipos motivacionais originais. Schwartz et al. (2012) argumentaram que a subdivisão em mais tipos motivacionais poderia melhorar o caráter preditivo dos Valores Humanos no comportamento. Torres, Schwartz e Nascimento (2014) encontraram essa maior predição no comportamento no Brasil. Os dezenove tipos motivacionais são apresentados na Tabela 8. 
Tabela 8

Tipos motivacionais da escala $P V Q-R$

\begin{tabular}{|c|c|c|}
\hline \multirow{19}{*}{ Valores Humanos } & SDT & Autodireção de Pensamento \\
\hline & DAS & Autodireção de Ação \\
\hline & ST & Estimulação \\
\hline & $\mathrm{HE}$ & Hedonismo \\
\hline & $\mathrm{AC}$ & Realização \\
\hline & POD & Poder de Domínio \\
\hline & POR & Poder sobre Recursos \\
\hline & FAC & Face \\
\hline & SES & Segurança Social \\
\hline & SEP & Segurança Pessoal \\
\hline & $\mathrm{TR}$ & Tradição \\
\hline & $\mathrm{COR}$ & Conformidade com Regras \\
\hline & COI & Conformidade Interpessoal \\
\hline & HUM & Humildade \\
\hline & BEC & Conformidade com Regras \\
\hline & BED & Benevolência Cuidado \\
\hline & UNC & Universalismo Compromisso \\
\hline & UNN & Universalismo Natureza \\
\hline & UNT & Universalismo Tolerância \\
\hline
\end{tabular}

Fonte: Adaptado de Schwartz et al. (2012)

Schwartz et al. (2012) sugere que na nova estrutura de valores, refinada, os tipos motivacionais são mais bem discriminados, mais claros portanto sendo capazes de serem relacionados mais facilmente com comportamentos específicos. A tabela 9 apresenta os 19 Valores da Teoria Refinada, definidos em termos de Metas Motivacionais.

Tabela 9

Os 19 Valores da Teoria Refinada, definidos em termos de Metas Motivacionais

Valor Definições Conceituais em Metas Motivacionais

Autodireção de Pensamento

Autodireção de Ação

Estimulação

Hedonismo

Realização

Poder de Domínio

Poder sobre Recursos
Liberdade para cultivar suas próprias ideias e habilidades

Liberdade para determinar suas próprias ações

Excitação, novidade e mudança

Prazer e gratificação sensual para si mesmo

Sucesso de acordo com os padrões sociais

Poder pelo exercício de controle sobre outras pessoas

Poder pelo controle sobre materiais e recursos sociais 
Face

Segurança Pessoal

Segurança Social

Tradição

Conformidade com Regras

Conformidade Interpessoal

Humildade

Benevolência Dependência

Benevolência Cuidado

Universalismo Compromisso

Universalismo Natureza

Universalismo Tolerância
Manutenção da sua imagem pública e evitar humilhações

Segurança em seu ambiente imediato

Segurança e estabilidade da sociedade (mais ampla)

Manutenção e preservação da cultura, família ou religião

Conformar-se com regras, leis e obrigações formais

Evitar chatear ou machucar outras pessoas

Reconhecimento da própria insignificância em um contexto amplo

Ser um membro confiável e fidedigno do endogrupo

Devoção ao bem-estar dos membros do endogrupo

Comprometimento com igualdade, justiça e proteção de todas as pessoas

Preservação do ambiente natural

Aceitação e compreensão daqueles que são diferentes de si mesmo

Fonte: Adaptada de Schwartz et al. (2012).

Schwartz et al. (2012) organizam os 19 tipos motivacionais em uma escala com 57 itens, sendo que cada um dos tipos motivacionais se alicerça em 3 itens, totalizando os 57. Para completar a subdivisão, Schwartz et al. (2012) utilizaram 344 amostras de 83 países e compararam as associações com os itens da escala SVS (Schwartz, 1992) e PVQ (Schwartz, 2005), utilizando escalonamento multidimensional (MDS), procurando por evidências visuais dos subtipos teorizados. Quando existiam evidências visuais do conceito teorizado, ele foi testado por análise confirmatória dos dados (CFA) e um novo subtipo foi criado; essas etapas foram realizadas para todos os subtipos. A versão final com 19 subtipos foi testada em versões com seis pontos e onze pontos, de Schwartz et al. (2012), e foi adotada a versão com seis pontos, pois esta apresentou melhor validade, confiabilidade e poder de discriminação (Schwartz et al., 2012)

Allen (2000) aponta que, ainda que os valores promovam os interesses de indivíduos e grupos sociais, motivando ações ou servindo como ponto de partida para que as pessoas 
julguem a si mesmo e outras, tais julgamentos e preferências dependem diretamente de dois processos, abstração e generalização. Rokeach (1973) e Feather (1982) sugerem que as crenças que um indivíduo possui sobre um objeto derivam das experiências positivas ou negativas, que ocorrem com tal objeto; e o resumo das avaliações sobre essas crenças formam uma atitude geral em relação àquele objeto.

Frente a essas proposições, Allen (2000) propõe que as sugestões de Rokeach (1973) e Feather (1982) são as mesmas demonstradas no modelo da teoria da expectância (Fishbein, 1967) que determina que cada crença possui uma avaliação associada a ela e tais combinações de crenças e avaliações combinadas com outras crenças e avaliações acerca do objeto formariam a atitude frente ao objeto. Portanto os valores determinam modo como as pessoas julgam o objeto e formam suas crenças acerca do mesmo, fazendo-se necessário entender como a relação entre valores e julgamento ocorre.

\subsubsection{Valores e Julgamento}

Allen (2006) aponta que na visão tradicional valores não influenciam a escolha de produtos diretamente, porém atenuam ou aumentam a importância de atributos tangíveis os quais guiam a escolha de produtos como demonstra a figura 5.

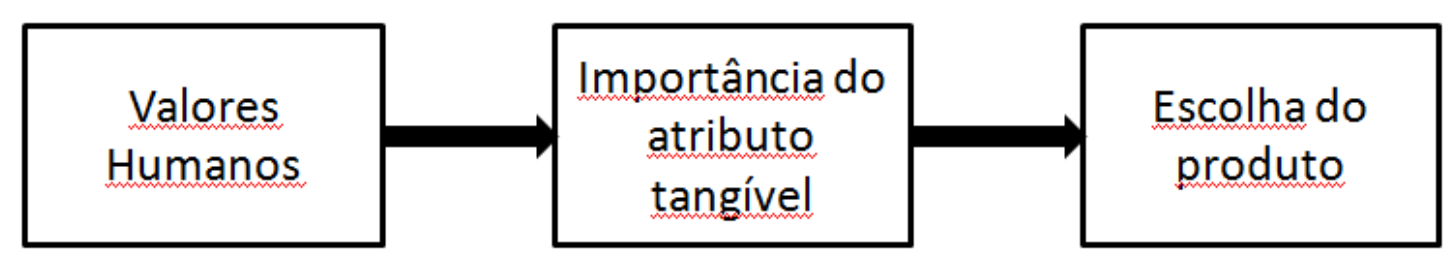

Figura 5. Visão Tradicional segundo Allen (2006)

Lindberg, Garling e Montgomery (1989) sugerem que a preferência entre produtos deriva dos valores que o atributo de um produto salienta e quão importante os consumidores consideram tal valor salientado. Allen (2006) salienta que, dessa maneira, os consumidores calculariam a utilidade ou preferência por algum produto ou marca, por uma fórmula matemática e, então, escolheriam o que obtivesse o resultado mais alto.

No entanto, Allen (2000) descreve que tal estrutura se restringe à importância dos atributos tangíveis de produtos, ou simplesmente "atributos tangíveis" como será tratada a variável de agora em diante, e pode ser considerada limitada, pois observa os valores humanos como influência indireta somente num processo de escolha, ao mesmo tempo em que analisa somente o valor utilitário dos produtos. Diversos estudos analisaram o processo 
de escolha sob outro aspecto, o aspecto hedônico. Hirschman e Holbrook (1982) sugerem que em produtos percebidos de maneira simbólica, suas características físicas pesam muito menos na escolha do que sua representatividade para o indivíduo e a simbologia que este atribui ao produto. Zajonc (1980) aponta por sua vez que a associação sentimental é imediata e antecede a cognição excluindo elementos de atenção e processamento que estão ligados à identificação do objeto, argumentando inclusive que a própria descrição do objeto depende da abstração e do significado deste aos olhos do individuo que o descreve, assim "as pessoas não descrevem objetos ou eventos pelo que estes são compostos, mas sim pelo que as compõe”, pois julgamentos afetivos seriam sempre descrições do self (Zajonc, 1980).

Concomitantemente, Lazarus (1982) questiona Zajonc (1980) argumentando que a "atividade cognitiva é condição antecessora necessária para que exista emoção uma vez que para sofrer emoção o indivíduo deve anteriormente compreender o que está acontecendo" (Lazarus, 1982, p.124). Ainda assim, Lazarus (1984) salienta que as preferências e o modo como elas são constituídas residem em uma zona incerta entre emoção e não emoção. Allen (2006) descreve dois tipos de julgamentos que derivam das discussões anteriores, um julgamento passo a passo, descrito nos estudos de Fiske e Pavelchack (1986) como "o tipo de julgamento que analisa atributo por atributo para avaliar o estímulo em uma ordem lógica, sequencial e sistemática que gera uma atitude geral do objeto como resultado da combinação da avaliação de cada atributo" (Allen, 2000, p.12), e o julgamento afetivo derivado dos estudos de Zajonc (1980), que reflete o objeto como um todo, oposto a comparar atributos separados, "o objeto é comparado como um protótipo mental e, caso ambos sejam congruentes, o afeto frente ao protótipo é transferido ao objeto analisado" (Allen, 2006, p.27).

Allen e Torres (2006), por seu turno, argumentam que o tipo de julgamento de um produto deriva do significado atribuído a ele pelo indivíduo, podendo englobar duas categorias, utilitário ou simbólico, sendo que o significado utilitário é representado pelos aspectos tangíveis e funcionais e está diretamente relacionado com a utilidade prática do produto, seu desempenho e eficiência. No significado simbólico, os atributos são intangíveis e representam uma imagem ou o simbolismo de um produto. Dittmar (2007, p. 34) define símbolo como "uma entidade que representa outra entidade, que pode possuir significado somente até o ponto em que existe um entendimento compartilhado entre pessoas que classificam aquele símbolo como real"; assim, o significado simbólico está ligado à cultura do grupo (Dittmar, 1992).

Allen (2006b) resume os dois tipos de julgamento apresentados, classificando-os de acordo com suas características, conforme a tabela 10. 
Tabela 10

Tipos de Julgamento

\begin{tabular}{|c|c|c|}
\hline Característica & Tipo de & gamento \\
\hline Significado do produto & Utilitário & Simbólico \\
\hline Conteúdo & Ressalta função e utilidade & $\begin{array}{l}\text { Categorias sociais e princípios } \\
\text { culturais (ideais, valores, } \\
\text { traços). }\end{array}$ \\
\hline Tipo de análise & Atributos tangíveis em separado & Produto como um todo \\
\hline Foco & Objetivo: No produto & $\begin{array}{l}\text { Subjetivo: } \mathrm{Na} \\
\text { representatividade do self do } \\
\text { invidíduo por meio do produto. }\end{array}$ \\
\hline Clareza conceitual & Clara & Vaga \\
\hline $\begin{array}{l}\text { Caracterização do } \\
\text { julgamento }\end{array}$ & Passo a passo & Afetivo \\
\hline Raciocínio & $\begin{array}{l}\text { Lógico, sistemático, atributo } \\
\text { por atributo }\end{array}$ & Holístico e intuitivo \\
\hline Ligação com o afeto & Retardada & Imediata \\
\hline Intensidade de afeto & Baixa: Avaliativa & Alta: Estado emocional \\
\hline Motivação & Instrumental & Expressiva \\
\hline Fonte de benefício & $\begin{array}{l}\text { Qualidade intrínseca do } \\
\text { produto, meio para um fim e } \\
\text { habilidade de controlar o meio. }\end{array}$ & $\begin{array}{l}\text { Uso do produto como fonte de } \\
\text { autoexpressão. }\end{array}$ \\
\hline $\begin{array}{l}\text { Relevância dos valores } \\
\text { humanos }\end{array}$ & Baixa & Alta \\
\hline $\begin{array}{l}\text { Identificação com o } \\
\text { produto }\end{array}$ & Fraca & Forte \\
\hline
\end{tabular}

Nota. Fonte: adaptado de Allen (2006)

No entanto, Allen (2000) aponta que a influência dos valores ocorre de maneiras diferentes nos processos de julgamento passo a passo e afetivo; no caso do julgamento baseado em características utilitárias, os valores humanos medeiam o peso dos atributos tangíveis do produto analisado; no caso do julgamento afetivo, os valores influenciariam diretamente a preferência do consumidor por uma abordagem holística do produto em questão.Os conceitos de significado, tipo de julgamento e preferência por produtos foram integrados por Allen $(1997 ; 2000)$ no modelo de duas rotas (MDR).

Segundo Nepomuceno e Torres (2005), o modelo de duas rotas (Allen, 1997) procura explicar a influência dos valores humanos sobre a tomada de decisão dos consumidores, seja por meio de sua influência sobre o tipo de julgamento realizado, seja sobre o significado de um produto. Allen (1997) explica que os valores humanos não influenciam a preferência pelo produto diretamente, mas influenciam a importância dos atributos do produto que, por sua vez, irão orientar a avaliação e compra deste produto. Esse 
modelo representa uma nova maneira de determinar como a escolha do produto é feita pelos consumidores e influenciada pelos valores endossados por eles, por intermédio do significado que atribuem ao produto (Alfinito, 2007), conforme figura 6.

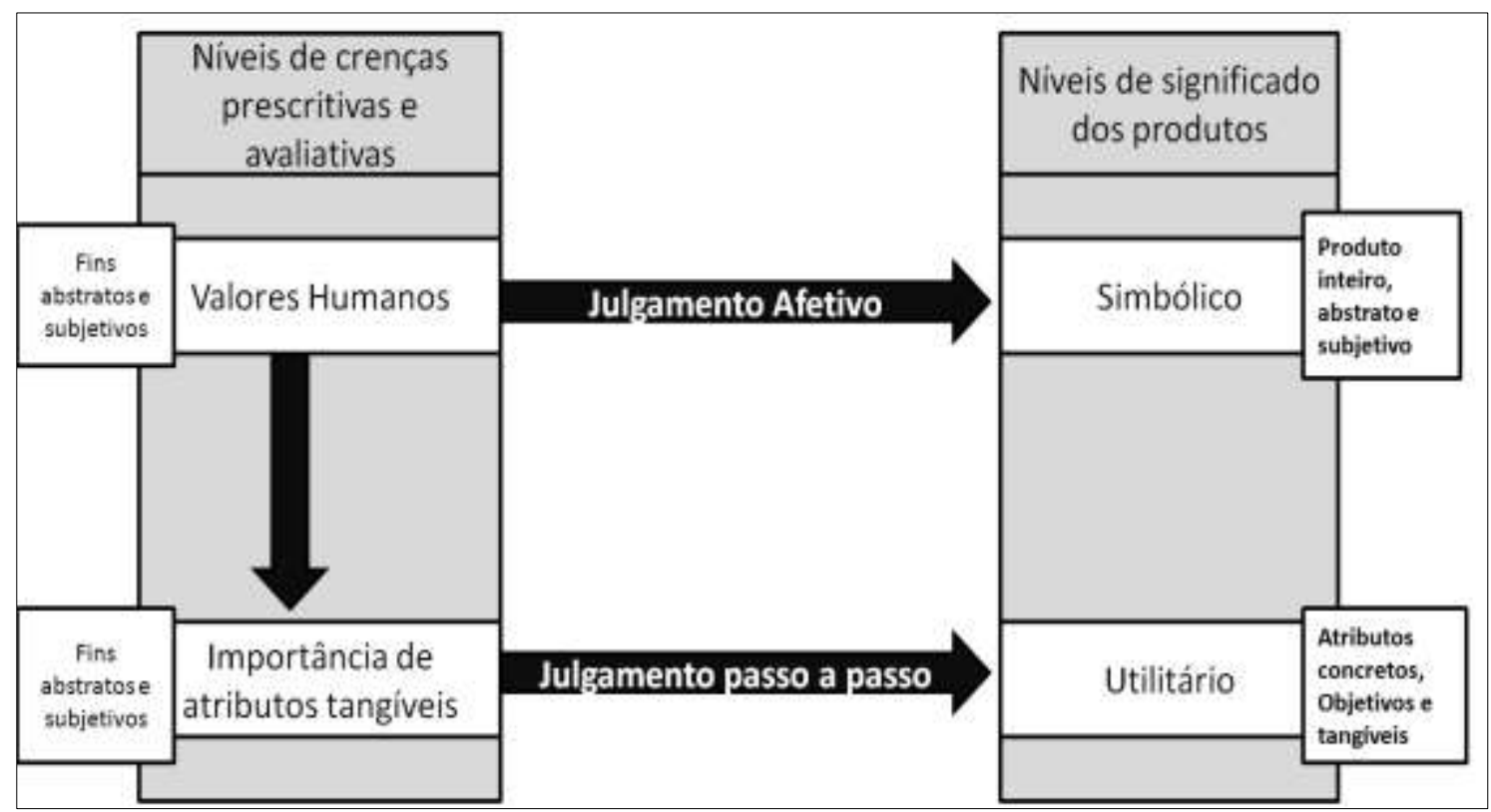

Figura 6. Representação conceitual do modelo de duas rotas

Fonte: Allen (1997)

É importante ressaltar que embora a figura proposta por Allen (1997) para representar o MDR possa levar a uma proposta racional e quase mecanicista do processo, na qual o julgamento prediria o significado, o modelo na verdade não propõe esta direção. $\mathrm{Ou}$ seja, não é o julgamento que prediz o significado. O significado do produto é atribuído pelo consumidor por diversas razões, em especial os valores endossados por ele ou ela. O que ocorre é que indivíduos que realizam julgamentos mais afetivos tem uma probabilidade maior de já terem atribuído significado simbólico ao bem (produto ou serviço), enquanto que o contrário é verdadeiro para o significado utilitário. A figura proposta para o modelo pelo próprio autor, logo, não se pretende descrever uma relação de causalidade ou antecedência. Assim, o MDR contribui para explicar frente a diferentes categorias de variáveis qual tipo de rota será utilizada para avaliar um determinado produto; tal caracterização psicológica permite dividir os grupos em termos de seus tipos de julgamentos e atribuições de significado. Faz-se, então, necessário apresentar a caracterização dos grupos analisados na presente pesquisa. Como idade é uma variável amplamente utilizada na literatura de Marketing ( Engel, Blackwell, Miniard, 2000) como segmentadora de mercado e definidora de público-alvo (Sheth, Mittal e Newman, 2001), a próxima sessão apresentará como idade e 
agrupamentos por idade são apresentados na literatura como elemento segmentador do mercado e caracterizador de grupos.

\subsubsection{Idade e agrupamento por idade}

De acordo com Rindfleisch (1994), mesmo que consumidores partilhem de uma mesma idade, são pessoas diferentes, uma vez que passaram por experiências individuais distintas. Porém, por terem sido submetidos aos mesmos eventos históricos e experiências advindas de um contexto econômico, cultural, social e político, vividos por eles a certa idade, torna-os mais parecidos, pois compartilham algumas experiências comuns. Solomon (2002) aponta que o entendimento de um grupo e suas características permitem definir mais apropriadamente elementos de um produto ou serviço e as técnicas mais efetivas para se comunicar com este grupo. Desta forma, como definido por Ryder (1965), indivíduos que nasceram no mesmo intervalo de tempo e foram submetidos a experiências similares em sua existência constituem um agrupamento geracional. O estudo dos coortes geracionais e suas divisões ao longo do fluxo histórico do tempo em períodos que constituam efetivamente uma Geração permite entender como o zeitgeist econômico, político e social influencia as diferentes gerações e como elas se constituem. O entendimento desse contexto auxilia a delinear padrões de comportamento e atitude dos indivíduos de idades semelhantes, sendo assim pertinente ao estudo do comportamento de consumo e suas aplicações gerenciais. Strauss e Howe (1991) apontam que os agrupamentos de idade são definidas com base em como indivíduos em diferentes estágios da vida são influenciados por importantes eventos sociais e históricos

Rindfleisch (1994) aponta que, apesar de sua longa história, o coorte por agrupamento de idades é um conceito que recaiu em obscuridade intelectual e recebeu atenção superficial pelos cientistas sociais, justificando que o problema reside na natureza do conceito em si, uma vez que o conteúdo geracional é multidisciplinar. Em exemplos de utilização já empregados, o coorte de agrupamento por idades já foi adotado por cientistas políticos para contabilizar mudanças em valores políticos (Inglehart, 1981), por sociólogos para examinar padrões de planejamento familiar (Hill, 1970), por psicólogos para entender o impacto das influências histórias no desenvolvimento humano (Schaie et al. 1973) e por administradores para explicar a tendência no consumo de bebidas entre pessoas de diferentes idades (Rentz \& Reynolds, 1991; Rentz, Reynolds \& Stout, 1983). 


\subsubsection{Bases sócio-histórico-políticas}

Como apontado por Ribeiro (1995, p. 126):

O processo de formação dos povos americanos tem especificidades que desafiam a 'explicação, sejam de povos transplantados cuja identidade étnica veio perfeitamente definida da Europa ou povos que se fizeram com configurações totalmente diferentes de suas matrizes, a busca da identidade étnica é tarefa do brasileiro a qual não pode ser a de mero europeu ultramar.

A identidade étnica do brasileiro foi construída no contexto nacional logo após o início da colonização; sua constituição e características se ancoram em ocorrências e eventos genuinamente únicos à realidade brasileira (Ribeiro, 1995). Assim, faz-se necessário entender a evolução histórica, econômica e política do Brasil à luz da literatura vigente.

Nos estudos de Giambiagi, Villela, Castro \& Hermann (2005), os períodos econômicos no Brasil são divididos em oito partes, em função das variações políticas ocorridas nos anos:

- 1945-1955: O pós-Guerra.

- 1956-1963: Dos anos dourados de Juscelino Kubitschek à crise não resolvida.

- 1964-1973: Reformas, Endividamento Externo e o “Milagre” Econômico.

- 1974-1984: Auge e Declínio do Modelo de Crescimento com Endividamento: O II Plano Nacional de Desenvolvimento e a crise da Dívida Externa.

- 1985-1989: Esperança, Frustração e Aprendizado: a História da Nova República.

- 1990-1994: Privatização, Abertura e Desindexação: a Primeira Metade dos anos de 1990.

- 1995-2002: Estabilização, Reformas, e Desequilíbrios Macroeconômicos: os Anos de Fernando Henrique Cardoso

- 2003-2010: Rompendo com a ruptura: o Governo Lula.

Em outra visão histórica, Martins Filho (2011) divide os períodos críticos da república em três partes:

- 1946-1964: A Democratização do Brasil

- 1964-1985: O Regime Militar.

- 1985-2010: A Nova República.

Bueno (2010) divide os períodos históricos em seis partes:

- 1945-1954: O fim da era Vargas 
- 1955-1964: A Era JK, Jango e Jânio.

- 1965-1984: Os anos de chumbo.

- 1985-1990: Das Diretas a Sarney.

- 1985-2002: De Collor a Fernando Henrique Cardoso.

- 2003-2010: O Brasil de Lula e do PT.

Assim, observa-se que ainda que Bueno (2010) divida os períodos no Brasil em seis partes e Giambiagi, Villela, Castro \& Hermann (2005) dividam em oito, Martins Filho (2011) apresenta uma abordagem que contempla todos os períodos históricos elencados. Os estudos de Shimp (2002), Solomon (2002), Sheth, Mittal e Newmann (2001) e Mowen e Minor (2003) apontam que as pessoas são definidas também por elementos marcantes de cada época, ou seja, um grupo de pessoas com idades semelhantes pode ser determinado por um intervalo de nascimentos, diferenciado da seguinte, conforme os fatos históricos vivenciados por cada um. Hawkins, Mothersbaugh e Best (2007) reforçam que pessoas que vivenciaram o mesmo ambiente.

Sheth, Mittal e Newmann (2001) argumentam que tanto as necessidades quanto os desejos variam imensamente de acordo com a idade. Assim, os indivíduos precisam estar em um determinado ciclo de vida para serem comparados com outros indivíduos no mesmo ciclo de vida (Ryder, 1965). É um consenso entre os autores que os períodos citados são pautados fortemente por mudanças políticas, que, consequentemente, ditaram características sociais e econômicas do Brasil.

No intuito de elaborar uma revisão sobre o que tem sido produzido no Brasil sobre comportamento do consumidor e o que tem sido produzido no mundo sobre avaliação de automóveis, faz-se necessário produzir um estudo da arte pertinente a esses temas. Assim, a próxima sessão dedica-se a aprofundar como a produção nacional tem se direcionado a respeito de comportamento de consumo e às abordagens adotadas em avaliação de automóveis em períódicos nacionais e internacionais.

\section{ESTADO DA ARTE}

\subsection{Introdução}

A fundamentação teórica de uma investigação apresenta como principal embasamento a revisão da literatura de cada variável relevante para a sua consecução. Diante disso, o presente capítulo é subdividido em dois estudos: o primeiro teve por objetivo apresentar o cenário dos estudos sobre comportamento do consumidor, mostrando os resultados de uma análise bibliométrica da produção de artigos; e o segundo apresenta as 
pesquisas com relação ao consumo de automóveis no Brasil e no restante do mundo. No primeiro estudo, estas pesquisas abrangem uma síntese do estado da arte e o cenário dos estudos produzidos no Brasil nos periódicos científicos de maior impacto, classificados entre os estratos A1 e B1 do Qualis CAPES (Coordenação de Aperfeiçoamento de Pessoal de Nível Superior, subordinado ao Ministério de Educação), na área de Administração, no período compreendido entre 2001 e 2013. Além disso, foi feita uma pesquisa sobre a institucionalização da pesquisa em comportamento do consumidor. Para tanto, foi concluído o levantamento no Portal Lattes do Conselho Nacional de Desenvolvimento Científico e Tecnológico (CNPq), do Ministério da Ciência, Tecnologia e Inovação, sobre diversos parâmetros relacionados ao tema comportamento do consumidor. No segundo estudo, foram considerados os artigos disponíveis nas bases de dados internacionais da Scielo, ScienceDirect e GoogleScholar.

\subsection{Pesquisa Bibliométrica: O Método Empregado}

Com vistas à consecução do objetivo do primeiro estudo, foi realizado um levantamento bibliográfico sobre comportamento do consumidor e preferência e compra de automóveis. Foram consideradas publicações em periódicos científicos da área de Administração. A escolha dos periódicos levou em consideração o fato de eles constarem no sistema Qualis/2012 de avaliação de periódicos da Coordenação de Aperfeiçoamento de Pessoal de Nível Superior (CAPES), com classificação igual ou superior a B1, além de estarem disponíveis em bases de dados de acesso público, no horizonte temporal de 2001 a 2013.

Os artigos publicados foram examinados em sua totalidade, durante o período assinalado; entretanto, foram descartados resenhas, relatos de experiências, notícias e os editoriais. Para o primeiro estudo foram considerados somente os artigos pertencentes à área do comportamento do consumidor, em razão de conterem no título, resumo ou palavras-chave para esse termo. Para o segundo estudo, foram considerados artigos que apresentassem no título, resumo ou palavras-chave referentes a automóveis e marketing, comportamento de compra ou consumo.

Após a seleção das fontes de coleta de informações, estipularam-se quais informações deveriam ser extraídas dos artigos. Como critérios, foram empregados os utilizados por Demo, et al. (2011). As informações foram: características da autoria, da metodologia empregada e dos principais resultados colhidos. No que se refere à autoria, foi 
identificada a origem geográfica dos autores, por instituição, e localizados, regionalmente, o nome do periódico e o ano de publicação.

Nos aspectos metodológicos, verificou-se o enquadramento do estudo (ensaios teóricos ou estudos teórico-empíricos). Foram considerados de natureza teórica tanto as investigações caracterizadas por revisões críticas de conceitos, os modelos e/ou teorias, bem como os estudos voltados à proposição de novos construtos ou modelos teóricos, em que não se utilizava qualquer teste ou coleta empíricos. Para os artigos empíricos, a classificação respeitou a necessidade de abranger procedimentos de coleta e análise de dados reservados a realizar descrições ou a comprovar hipóteses e/ou modelos teóricos.

Em seguida, os artigos empíricos foram analisados quanto à sua finalidade, ao tipo de amostra utilizada, ao tipo de instrumento adotado na coleta de dados e ao tipo de procedimento de análise dos dados. No que se refere à finalidade, os artigos foram prenotados em três categorias diferentes, em virtude do objetivo principal, seja esse: a) explicativo, b) descritivo ou c) exploratório na geração de conhecimentos sobre valores organizacionais.

No estudo 1 buscou-se, em continuação, identificar a função desempenhada pelo comportamento do consumidor nos estudos empíricos voltados à produção de conhecimentos. Nessa abordagem, avaliou-se: a) se os artigos trataram especificamente do comportamento do consumidor, ou seja, se essa era a única variável em estudos descritivos; b) se o comportamento do consumidor se constituía na variável antecedente de estudos dedicados a pesquisar sua influência em outros fenômenos micro ou macro-organizacionais; ou c) se os comportamentos do consumidor eram abordados como variável consequente de estudos preocupados em investigar a influência de fenômenos micro ou macro-organizacionais sobre esse comportamento.

A análise do método de pesquisa buscou responder se os estudos utilizaram: a) survey; b) pesquisa-ação; c) a etnografia ou observação participante; ou d) pesquisa documental ou bibliográfica. Com relação ao tipo de instrumento aplicado na coleta de dados, os estudos foram analisados levando-se em consideração sua forma de condução, isto é: a) mediante a utilização de questionários ou escalas de autorrelato; b) entrevistas; c) roteiro de observação ou d) com a análise de dados secundários.

Por fim, no que tange aos procedimentos de análise de dados, a classificação dos artigos respeitou três diferentes categorias, a saber: a) análise qualitativa (análise de material verbal por intermédio de análise de conteúdo, de discurso, entre outras); b) análise quantitativa; c) análise híbrida, ou seja, qualitativa-quantitativa. 
No estudo 2, em função da característica transcultural da pesquisa no tema, os artigos relativos à compra e ao consumo de automóveis consideraram periódicos internacionais, por intermédio de busca online pelo website sciencedirect, Google Scholar e Scielo. Os artigos encontrados foram relatados e apresentados de maneira descritiva, resumindo seu foco e área de análise bem como métodos empregados e objetivos almejados.

\subsection{Estudo 1 - Análise bibliométrica em comportamento do consumidor}

\subsubsection{Descrição e análise dos resultados bibliométricos}

Esta seção abordará, em primeira instância, a síntese ilustrada do levantamento dos 180 artigos encontrados nos periódicos de Administração nos últimos treze anos. Por fim, enuncia-se uma análise dessa produção que convida a algumas reflexões, já engendrando a proposição de uma agenda de pesquisa.

A Tabela 11 apresenta os periódicos científicos examinados para a consecução do objetivo proposto para este trabalho; além disso, fornece informação sobre as revistas acadêmicas específicas da área da Administração, com seu ISSN e sua classificação no Qualis/2012, perfazendo um total de 25 periódicos.

Tabela 11

Lista de Periódicos de Administração Analisados

\begin{tabular}{|c|c|c|c|c|}
\hline $\mathbf{N}$ & ISSN & Título Padronizado & $\begin{array}{c}\text { N de } \\
\text { Artigos }\end{array}$ & Qualis \\
\hline 1 & $1807-7692$ & BAR. Brazilian Administration Review & 7 & $\mathrm{~A} 2$ \\
\hline 2 & $1808-2386$ & BBR. Brazilian Business Review (English Edition. Online) & 6 & A2 \\
\hline 3 & $0104-530 X$ & Gestão \& Produção (UFSCAR. Impresso) & 2 & A2 \\
\hline 4 & $1984-9230$ & Organizações \& Sociedade (Online) & 2 & A2 \\
\hline 5 & $1982-7849$ & RAC. Revista de Administração Contemporânea (Online) & 12 & $\mathrm{~A} 2$ \\
\hline 6 & $2178-938 X$ & RAE - Revista de Administração de Empresas & 12 & A2 \\
\hline 7 & $1984-6142$ & RAUSP - Revista de Administração (São Paulo. Online) & 6 & A2 \\
\hline 8 & $0034-7612$ & Revista de Administração Pública (Impresso) & - & A2 \\
\hline 9 & $1679-3951$ & Cadernos EBAPE.BR $($ FGV $)$ & 2 & B1 \\
\hline 10 & $1678-4855$ & Desenvolvimento em questão (Unijuí) & - & B1 \\
\hline 11 & $0873-7444$ & Economia Global e Gestão & - & B1 \\
\hline 12 & $1984-6975$ & Faces: Revista de Administração (Belo Horizonte. Online) & 17 & B1 \\
\hline 13 & $2176-5308$ & Gestão \& Regionalidade (Online) & 6 & B1 \\
\hline 14 & $1517-3879$ & Organizações Rurais e Agroindustriais (UFLA) & 8 & B1 \\
\hline 15 & $1809-2039$ & RAI : Revista de Administração e Inovação & 5 & B1 \\
\hline 16 & $1678-6971$ & RAM. Revista de Administração Mackenzie (Online) & 6 & B1 \\
\hline 17 & $1413-2311$ & $\begin{array}{l}\text { REAd. Revista Eletrônica de Administração (Porto Alegre. } \\
\text { Online) }\end{array}$ & 46 & B1 \\
\hline 18 & 1983-0807 & Revista Brasileira de Gestão de Negócios (Online) & 13 & B1 \\
\hline 19 & $1809-239 X$ & Revista Brasileira de Gestão e Desenvolvimento Regional & 1 & B1 \\
\hline
\end{tabular}




\begin{tabular}{llcll}
20 & $1679-5350$ & Revista de administração da Unimep & 19 & B1 \\
21 & $2175-8077$ & Revista de Ciências da Administração & 9 & B1 \\
22 & $1982-6486$ & Revista de Contabilidade e Organizações & - & B1 \\
23 & $1807-1775$ & Revista de Gestão da Tecnologia e Sistemas de Informação & 1 & B1 \\
24 & $1677-2067$ & (Online) & - & B1 \\
25 & $0103-9989$ & Revista Portuguesa e Brasileira de Gestão (Rio de Janeiro) & - & B1 \\
\hline
\end{tabular}

Nota. Fonte: Elaborado pelo autor

A inspeção da Tabela 11 mostra a lista total dos periódicos científicos brasileiros da área de administração, de acordo com a última classificação Qualis/CAPES. Em primeiro lugar, vale salientar que nenhuma publicação está classificada como A1. Entre as revistas analisadas, apenas seis não apresentaram publicações que podem ser classificadas na categoria de estudos do comportamento do consumidor. Cabe ainda ressaltar, um elevado número de artigos publicados, 180 para um período que compreende 2001 a 2013, comparado-se a outras temáticas, como políticas de gestão de pessoas em que Demo et al. (2011) encontraram 108 artigos, num período de 2000 a 2010, numa revisão que compreendeu artigos classificados entre os estratos A1 e B2 do Qualis/CAPES.

Os resultados por ora coligidos corroboram o que foi encontrado na revisão de Vieira (2002), quais sejam, evidências de um interesse crescente dos pesquisadores brasileiros pelo tema exposto, tanto no contexto da psicologia quanto da administração, o que ratifica a ênfase que as investigações acerca do comportamento do consumidor obtiveram nas últimas décadas, na literatura internacional. Mesmo que alguns temas específicos, que envolvem conteúdos desde a segmentação (Vieira, 2002) até a relação de dimensões diversas (por exemplo, individualismo e coletivismo) no comportamento do consumidor (Watanabe, 2014), ainda sejam esparsos no Brasil houve aumento do número de publicações, desde a revisão feita por Vieira (2002).

Os resultados também revelaram a concentração de publicações em torno de alguns periódicos: a Revista Eletrônica de Administração Contemporânea com quarenta e seis artigos (25,56\%), a Revista de Administração da UNIMEP com dezenove (10,56\%), a FACES: Revista de Administração com dezessete artigos (9,44\%), a Revista Brasileira de Gestão de Negócios com treze artigos (7,22\%) e, por fim, a Revista de Administração Contemporânea e a Revista de Administração de Empresas, ambas com doze artigos (6,67\%) cada. De forma acessória, a Tabela 8 também apresenta os periódicos que não publicaram ou que apresentaram um número de de até dois artigos sobre comportamento do consumidor, no período considerado. 
No recorte temporal escolhido para o estudo, a média alcançada foi de 13,85 artigos por ano. Dessa forma, no que se refere aos anos de produção, constata-se a maior produção, com igual número de artigos, em 2006, 2008 e 2013 (11,11\% em cada ano), seguida (a produção) pelos anos 2011 e 2012 (10,56\% em cada ano) e 2010 (9,44\%). Na sequência, têmse os anos 2007 com 8,33\%, 2005 na marca de 7,22\% e 2004 e 2009, ambos com 6,11\% cada um. O índice de 5,0\% é alcançado no ano 2003. Os anos 2001 e 2002 registraram 1,67\% de produção dos artigos. Vale destacar que a variação de artigos publicados no período de 2010 até 2013 não apresentou uma diferença grande na quantidade de artigos publicados, variando de 1 a 3 artigos. Entretanto, os anos anteriores (2001 a 2013) apresentaram uma tendência de aumento nas publicações, mesmo ocorrendo duas reduções nos ano de 2007 e 2009, o que poderia significar uma consolidação do campo. A figura 11 mostra esses resultados.

Com base em três artigos por ano, para as datas de 2001 e 2002, há um crescimento quase assintótico ao visível na figura 7. Poder-se-ia supor que o patamar de vinte artigos por ano ainda é um limiar a ser ultrapassado. No momento, não há elementos suficientes para explicar as quedas ocorridas em 2007 e 2009. Esta última parece ser mais anômala, mesmo que, gradativamente, retome ao limiar de 20 artigos, em 2013.

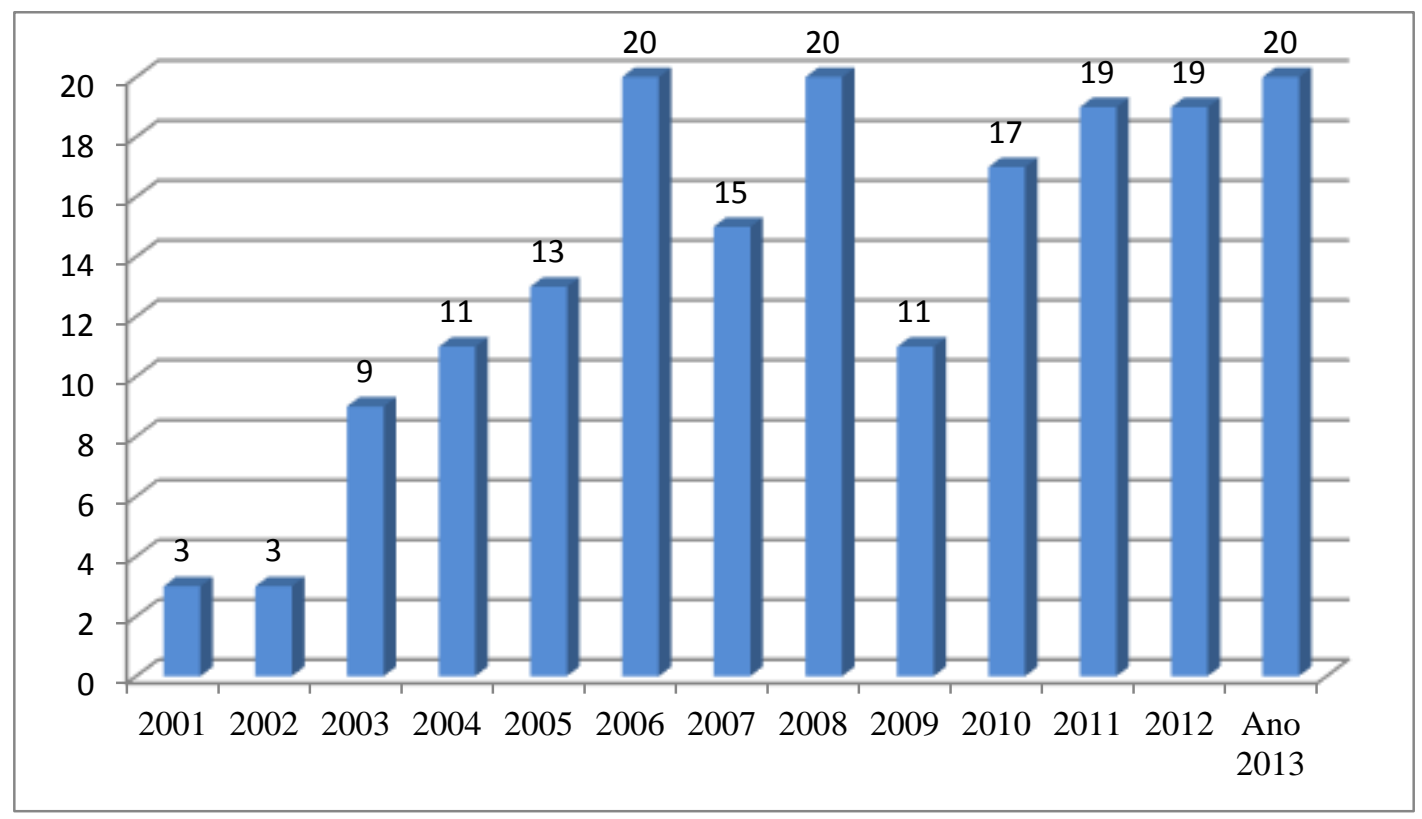

Figura 7. Artigos relacionados a comportamento do consumidor publicados por ano.

Fonte: Elaborado pelo autor

Quando se observa a distribuição por instituição acadêmica dos autores de cada artigo, constata-se o percentual mais acentuado de autores provenientes da Universidade de 
São Paulo (12,46\%), seguido pela Fundação Getúlio Vargas $(6,73 \%)$ e pela Universidade Federal do Rio Grande do Sul (6,39\%). A figura 8 aponta a divisão institucional, baseada em três artigos, entre os 180 artigos analisados. No total, 97 instituições acadêmicas foram elencadas como contribuintes nos artigos, seja como local de trabalho dos pesquisadores, seja como local de obtenção da última titulação pelos autores.

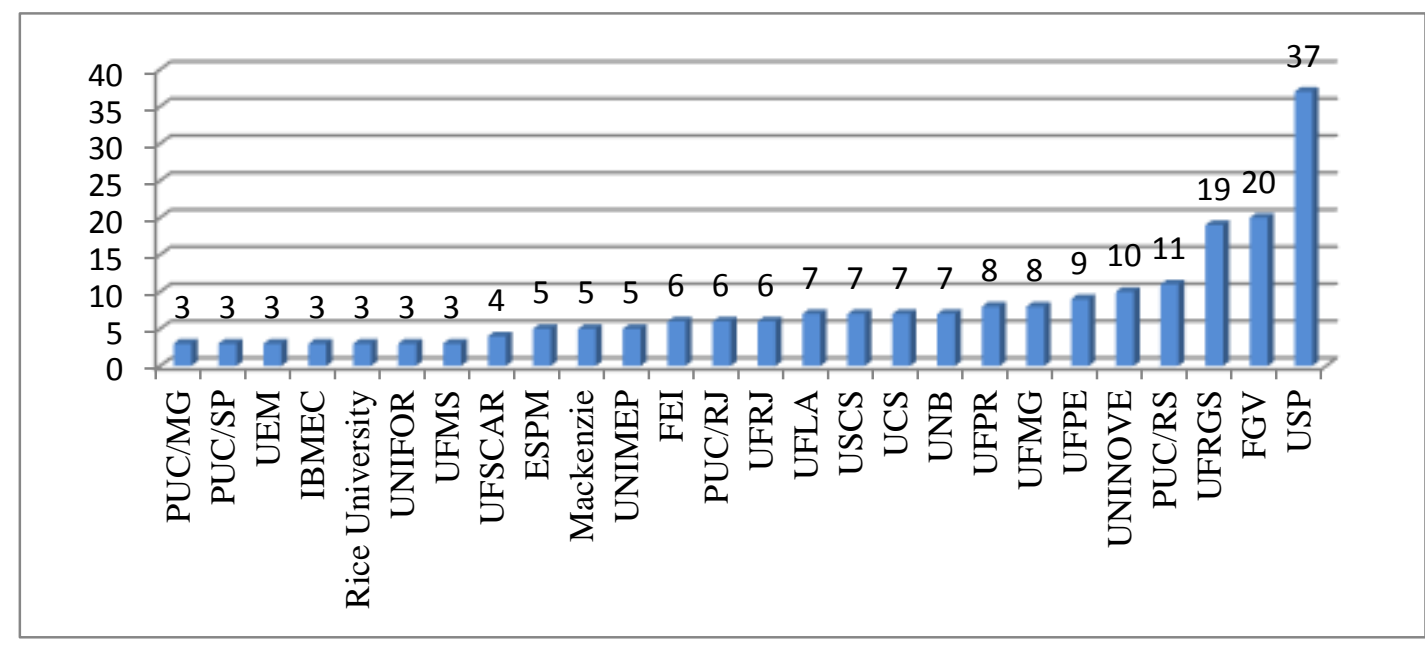

Figura 8. Universidades com maior número de autores

Fonte: Elaborado pelo autor.

A maioria dos estudos enquadrou-se no modelo teórico-empírico (85\% ou 153 estudos), enquanto apenas vinte e sete estudos caracterizaram-se como ensaios teóricos (15\%). Dos artigos teóricos (27 artigos), passíveis de se reconhecer a finalidade, ou seja, de revisar/discutir ou de caráter propositivo, as análises mostram que a esmagadora maioria dos artigos teóricos (92,59\% ou 25 artigos) visa revisar/discutir o comportamento do consumidor. No que diz respeito à finalidade dos estudos, a quase totalidade, 92,78\% (de 167 artigos) teve como foco a geração de conhecimento, restando 7,22\% para a geração de instrumentos de medida, o que pode ser interpretado como a persistência de uma importante lacuna nos estudos brasileiros. Grande parte dos estudos teórico-empíricos são não probabilísticos e seu desenho foi construído com a utilização de survey (142 artigos), encontrando-se ainda outros tipos, tais como experimentais ( 8 artigos) e pesquisa-ação (3 artigos).

No que se refere aos artigos teóricos-empíricos, os instrumentos utilizados dividiramse entre os que aplicaram exclusivamente questionários $(56,86 \%)$, que fizeram o uso apenas de entrevistas (9,80\%), que analisaram documentos (7,19\%), que associaram entrevistas e questionários $(13,73 \%)$, e mais $4,58 \%$ associaram três ou mais instrumentos. Um total de 7,84\% dos artigos teóricos-empíricos foram classificados como outros (por exemplo, análise de desenhos, observação, grupo focal, entre outros). 
A figura 9 apresenta os instrumentos de forma geral e não exclusiva; portanto, das 118 pesquisas que adotaram o questionário, por exemplo, a maior parte (87 artigos) aplicou-o como instrumento único de coleta de dados, e, em 31 casos, este foi empregado em conjunto com outros instrumentos. Trinta e seis artigos valeram-se de mais de um instrumento de coleta de dados.

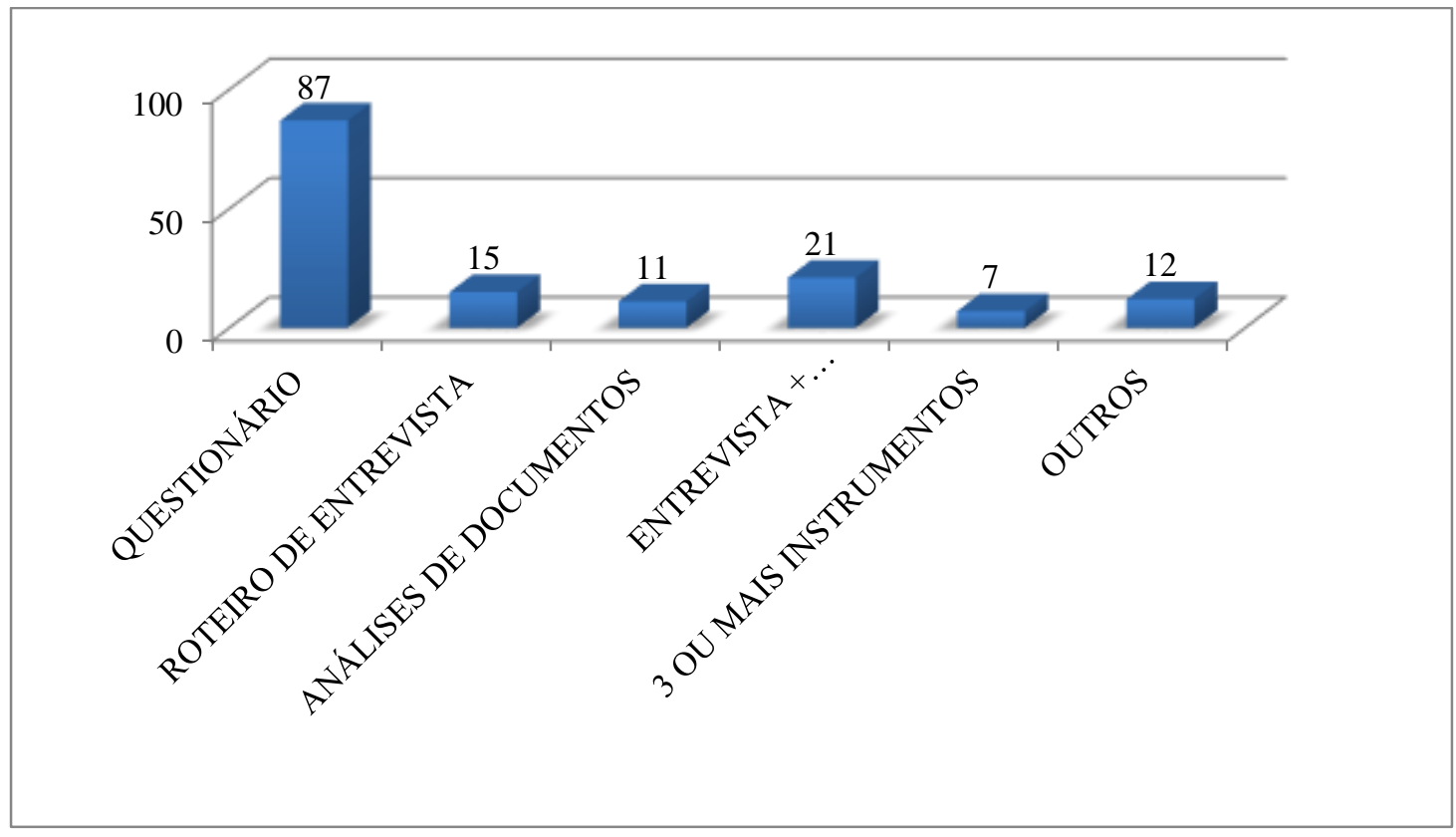

Figura 9. Instrumentos utilizados exclusivamente ou em associação Fonte: Elaborado pelo autor.

Entre os trabalhos teórico-empíricos (153), 20,26\%, são de natureza qualitativa, $59,48 \%$ foram estudos de natureza quantitativa; e 20,26\% de natureza híbrida, ou seja, mesclaram métodos qualitativos e quantitativos (quali-quanti). A figura 10 apresenta esses resultados.

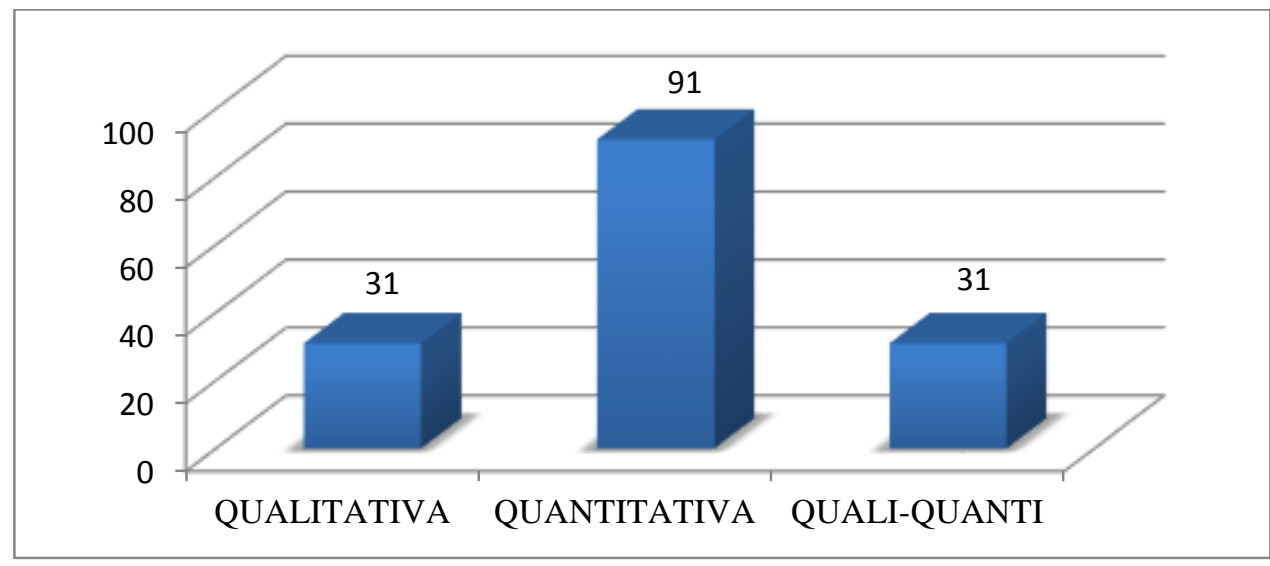

Figura 10. Natureza dos artigos teórico-empíricos 
Fonte: Elaborado pelo autor.

Em relação às técnicas utilizadas para as análises dos dados, grande parte dos estudos usou técnicas mistas $(47,06 \%)$, as análises de conteúdo responderam por 13,73\%, restando $1,96 \%$ para análise do discurso. A análise fatorial, de forma exclusiva, foi empregada por $9,80 \%$ e a modelagem por equações estruturais por 4,58\%. As análises descritivas contemplaram 9,15\%. A figura 11 mostra a quantidade de artigos discriminados pelas técnicas de análise utilizadas.

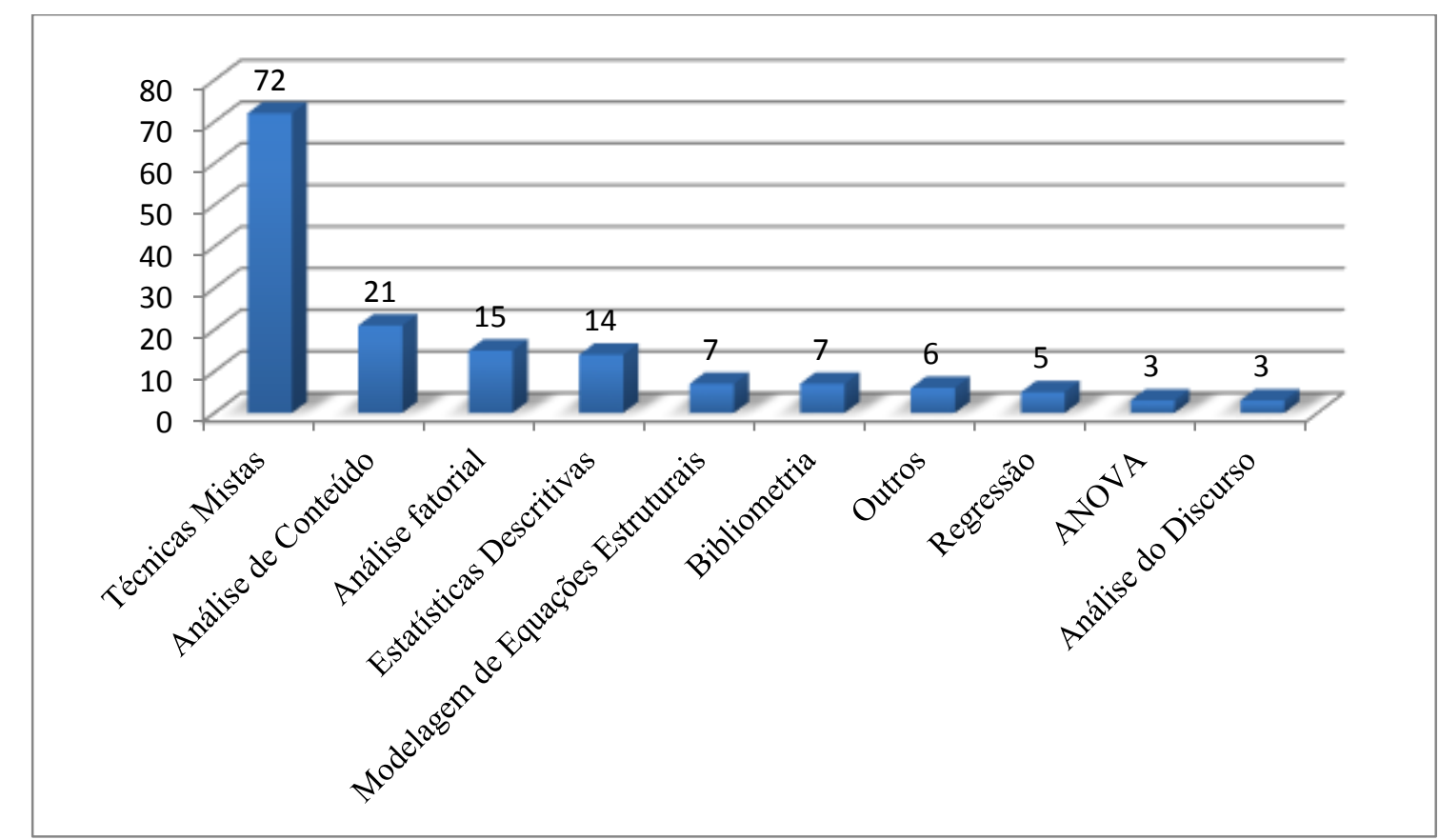

Figura 11. Técnicas de análise utilizadas nos artigos de Valores Organizacionais Fonte: Elaborado pelo autor.

Esta análise desvelou a necessidade de se aumentarem os estudos que fazem uso de estatísticas inferenciais, sobretudo as análises mais robustas, que utilizam estatísticas multivariadas e técnicas mais sofisticadas, como modelagem por equações estruturais e análise multinível, sendo que, na revisão conduzida, não se encontrou qualquer artigo que tenha empregado esta última técnica.

Por fim, todos os artigos foram analisados quanto aos assuntos tratados. Os termos classificatórios constam da figura 12: 


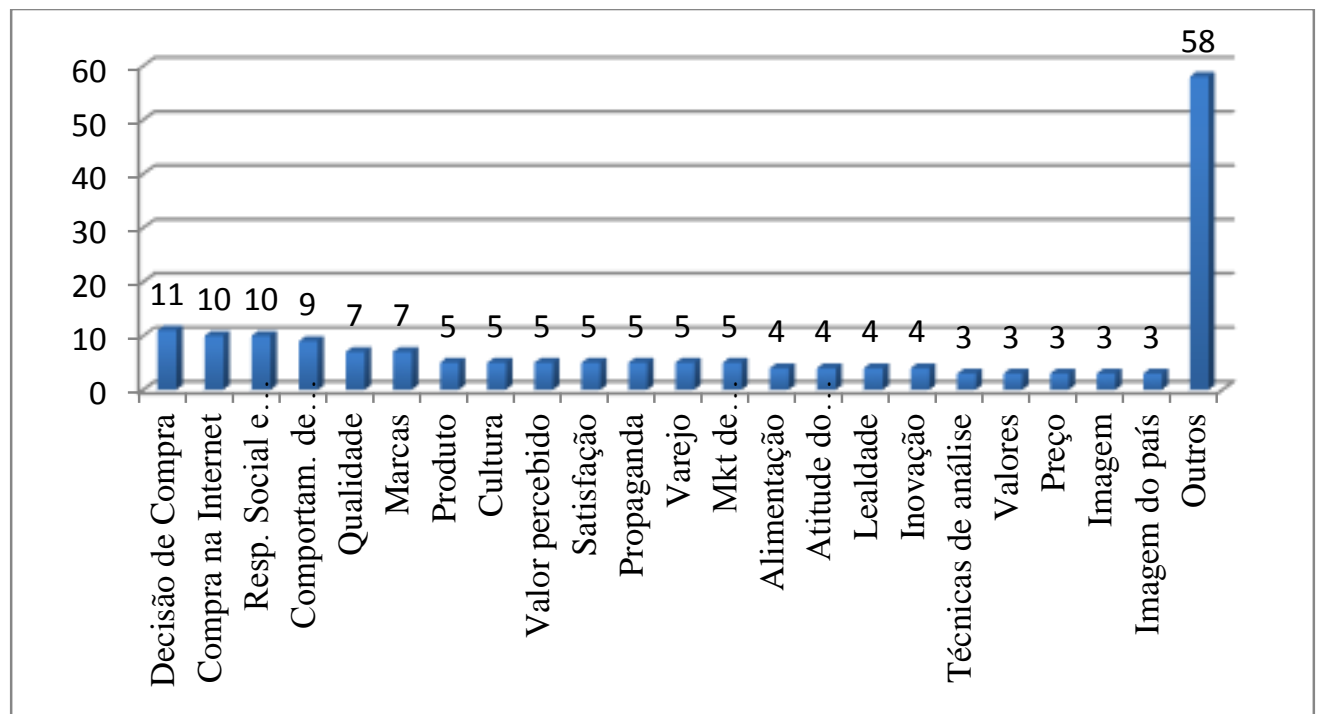

Figura 12. Assuntos mais estudados entre as pesquisas de Comportamento do Consumidor Fonte: Elaborado pelo autor.

O tema com maior número de referência foi o de decisão de compra $(n=11)$. Logo em seguida aparecem pesquisa sobre compras na internet, responsabilidade social e ecológica (ambas com $n=10)$ e comportamento de consumo $(n=9)$. Com uma aparição razoável, encontram-se assuntos relativos à qualidade $(n=7)$ e às marcas $(n=7)$. Posteriormente, os assuntos são equilibradamente distribuídos, abordando temáticas bastantes diversas, entre as quais se destacam produto e cultura ( $n=5$ para ambas), lealdade e inovação ( $n=4$ para ambas) e preço e imagem ( $n=3$ para ambas). Certos assuntos não puderam ser sistematizados nas categorias relacionadas e foram classificados como outros $(n=58)$. Em termos gerais, apesar de ainda sem levar em consideração o que foi efetivamente investigado, boa parte das dez temáticas mais frequentes também foram objeto de revisões internacionais recentes (Watanabe, 2014).

Após essa apresentação da análise bibliométrica sobre comportamento do consumidor nos principais periódicos brasileiros, abordar-se-á a institucionalização do campo de investigação do comportamento do consumidor no Brasil.

\subsubsection{Institucionalização da Pesquisa sobre Comportamento do Consumidor no Brasil}

A institucionalização da pesquisa sobre o tema genérico "comportamento do consumidor", no Brasil, foi investigada com base nos grupos de pesquisa cadastrados na Base do Diretório de Grupos de Pesquisa do Conselho Nacional de Desenvolvimento Científico e Tecnológico (CNPq), em 18 de fevereiro de 2014, tanto na base atual como na base de Censos Anteriores da Plataforma Lattes. 
Com relação à base de pesquisadores atual, foram localizados 104 grupos de pesquisa, para a expressão exata "comportamento do consumidor". A Tabela 12 apresenta os grupos de pesquisa sobre comportamento do consumidor, de acordo com a unidade federativa e a sigla da instituição, seguidos pelo nome oficial do grupo e a quantidade de grupos de pesquisa por unidade federativa.

Tabela 12

Grupos de pesquisa sobre comportamento do consumidor

\begin{tabular}{|c|c|c|c|}
\hline UF & Instituição & Nome dos grupos em “comportamento do consumidor" & $\mathbf{N}^{\circ}$ de grupos \\
\hline $\mathrm{AC}$ & IFAC & Grupo de Pesquisa em Mercadologia Rio Branco - GPM & 1 \\
\hline AL & UFAL & $\begin{array}{l}\text { Empreendedorismo, geração de negócios e turismo: realidade e } \\
\text { perspectiva em Alagoas }\end{array}$ & 1 \\
\hline AM & UFAM & Criação e Manejo de Animais Silvestres & 1 \\
\hline \multirow{4}{*}{ BA } & UESC & Dados e Conjuntura & 4 \\
\hline & UNIFACS & Grupo de Pesquisa em Gestão Estratégica de Marketing & \\
\hline & UFBA & Grupo de Pesquisa em Marketing Federal - BA & \\
\hline & IFBA & Trabalho, Desenvolvimento e Tecnologias de Gestão & \\
\hline \multirow{7}{*}{$\mathrm{DF}$} & \multirow{6}{*}{ UNB } & Cultura, Inovação, Internacionalização e Práticas Sociais CULTI & 7 \\
\hline & & $\begin{array}{l}\text { Experimenta - Grupo de Pesquisa em Desempenho de Marketing e } \\
\text { Estratégia }\end{array}$ & \\
\hline & & Grupo de Estudo em Nutrição Social & \\
\hline & & Grupo Consuma & \\
\hline & & Grupo de Pesquisas em Gestão de Pessoas e Clientes & \\
\hline & & Núcleo de Pesquisa em Cultura, Valores e Comportamento & \\
\hline & UniCEUB & Educação Superior e Comunicação - EDUCACOM & \\
\hline \multirow{3}{*}{ ES } & FUCAPE & CEME - Centro de Pesquisa em Marketing e Estratégia & 3 \\
\hline & \multirow[b]{2}{*}{ IFES } & Estratégia Organizacional & \\
\hline & & $\begin{array}{l}\text { Grupo de Estudos e Pesquisa em Administração e Educação } \\
\text { Profissional - GEPAEP }\end{array}$ & \\
\hline GO & PUC GOIÁS & Análise Experimental do Comportamento - LAEC & 1 \\
\hline \multirow{11}{*}{ MG } & \multirow{2}{*}{$\mathrm{UFV}$} & Análise Sensorial de Alimentos & 13 \\
\hline & & Núcleo de Estudos sobre Autogestão e Desenvolvimento & \\
\hline & \multirow{2}{*}{ FUMEC } & Comportamento do Consumidor & \\
\hline & & Logística e Operações & \\
\hline & \multirow{2}{*}{ UFJF } & Cor e Forma & \\
\hline & & Viagem, imaginários e socialidade & \\
\hline & \multirow{3}{*}{ UFU } & Envolvimento Social Corporativo e Proteção Ambiental & \\
\hline & & $\begin{array}{l}\text { GEMAVCC - Grupo de Estudos em Marketing de Varejo e } \\
\text { Comportamento do Consumidor }\end{array}$ & \\
\hline & & Valores pessoais no consumo & \\
\hline & PUC Minas & Grupo de Estudos de Estratégias Organizacionais - GESTOR & \\
\hline & UFLA & Marketing e Comportamento do Consumidor - & \\
\hline
\end{tabular}




\begin{tabular}{|c|c|c|c|}
\hline & UFMG & NECC - Núcleo de Estudos do Comportamento do Consumidor & \\
\hline & UFOP & Núcleo de Pesquisas e Estudos Avançados em Turismo & \\
\hline \multirow{5}{*}{ MS } & \multirow{5}{*}{ UFMS } & $\begin{array}{l}\text { GRUCOA - Grupo de Competitividade de Organizações } \\
\text { Agroindustriais }\end{array}$ & 5 \\
\hline & & Gestão Organizacional & \\
\hline & & Gestão e Desenvolvimento Regional & \\
\hline & & Gestão, Turismo e Sustentabilidade & \\
\hline & & $\begin{array}{l}\text { NEXCOC Núcleo de Estudos Experimentais no Comportamento do } \\
\text { Consumidor }\end{array}$ & \\
\hline $\mathrm{PA}$ & UNAMA & Marketing Tecnológico (Consumer Behavior) & 1 \\
\hline \multirow{2}{*}{ PB } & IFPB & Grupo de Pesquisa em Gestão e Psicologia Social & 2 \\
\hline & UEPB & Terceira Idade: Comportamento, Gênero e Estilo de Vida & \\
\hline \multirow{5}{*}{$\mathrm{PE}$} & \multirow{2}{*}{ UFRPE } & Administração & 5 \\
\hline & & PLURAL - Moda e Vestuário & \\
\hline & \multirow{3}{*}{ UFPE } & CHT - Centro de Estudos em Hospitalidade, Turismo e Gastronomia & \\
\hline & & Grupo de Apoio a Gestão Econômico-Integrada & \\
\hline & & MKP - Centro de Estudos em Marketing e Pessoas & \\
\hline \multirow{9}{*}{ PR } & \multirow{3}{*}{ UFPR } & $\begin{array}{l}\text { Comportamento do Consumidor e Estratégias de Relacionamento em } \\
\text { Marketing }\end{array}$ & 9 \\
\hline & & Estratégias de Marketing & \\
\hline & & $\begin{array}{l}\text { Estudo e Desenvolvimento de Estratégias, Marketing e } \\
\text { Competitividade }\end{array}$ & \\
\hline & \multirow{2}{*}{ UEL } & GEPEM - Grupo de Estudos e Pesquisa em Estratégia e Marketing & \\
\hline & & Grupo de Economia Aplicada & \\
\hline & UNESPAR & Ensino de Administração & \\
\hline & UEM & Grupo Interdisciplinar de Pesquisas e Estudos em Marketing & \\
\hline & PUC/PR & Marketing - Comportamento do Consumidor & \\
\hline & UP & NUMAR - Núcleo de Pesquisa em Marketing & \\
\hline \multirow{6}{*}{$\mathrm{RJ}$} & UFRJ & Estudo sobre o Comportamento do Consumidor & 6 \\
\hline & \multirow{2}{*}{ UFRRJ } & Grupo de Estudos em Marketing e Consumo & \\
\hline & & NEIL - Núcleo de Estudos sobre Inovações e Liderança & \\
\hline & \multirow{2}{*}{ UFF } & Labcons - Laboratório de Estudos de Consumo & \\
\hline & & Turismo: Gestão e Território & \\
\hline & UNESA & Organizações & \\
\hline \multirow{2}{*}{$\mathrm{RN}$} & UNP & Estudos, Politicas e Tecnologias de Gestão Organizacional & 2 \\
\hline & UERN & Núcleo de Estudos Organizacionais do Alto Oeste Potiguar - NEOP & \\
\hline \multirow{6}{*}{ RS } & \multirow{2}{*}{ UFSM } & Estratégias Inovadoras para Sustentabilidade Organizacional & 15 \\
\hline & & Marketing & \\
\hline & \multirow{2}{*}{ UFRGS } & GPS - Grupo de Pesquisa em Sustentabilidade e Inovação & \\
\hline & & Grupo de Pesquisas sobre Marketing e Consumo (GPMC) & \\
\hline & \multirow{2}{*}{ UNISC } & Grupo de Estudos em Gestão de Negócios & \\
\hline & & Gestão Estratégica de Marketing & \\
\hline
\end{tabular}




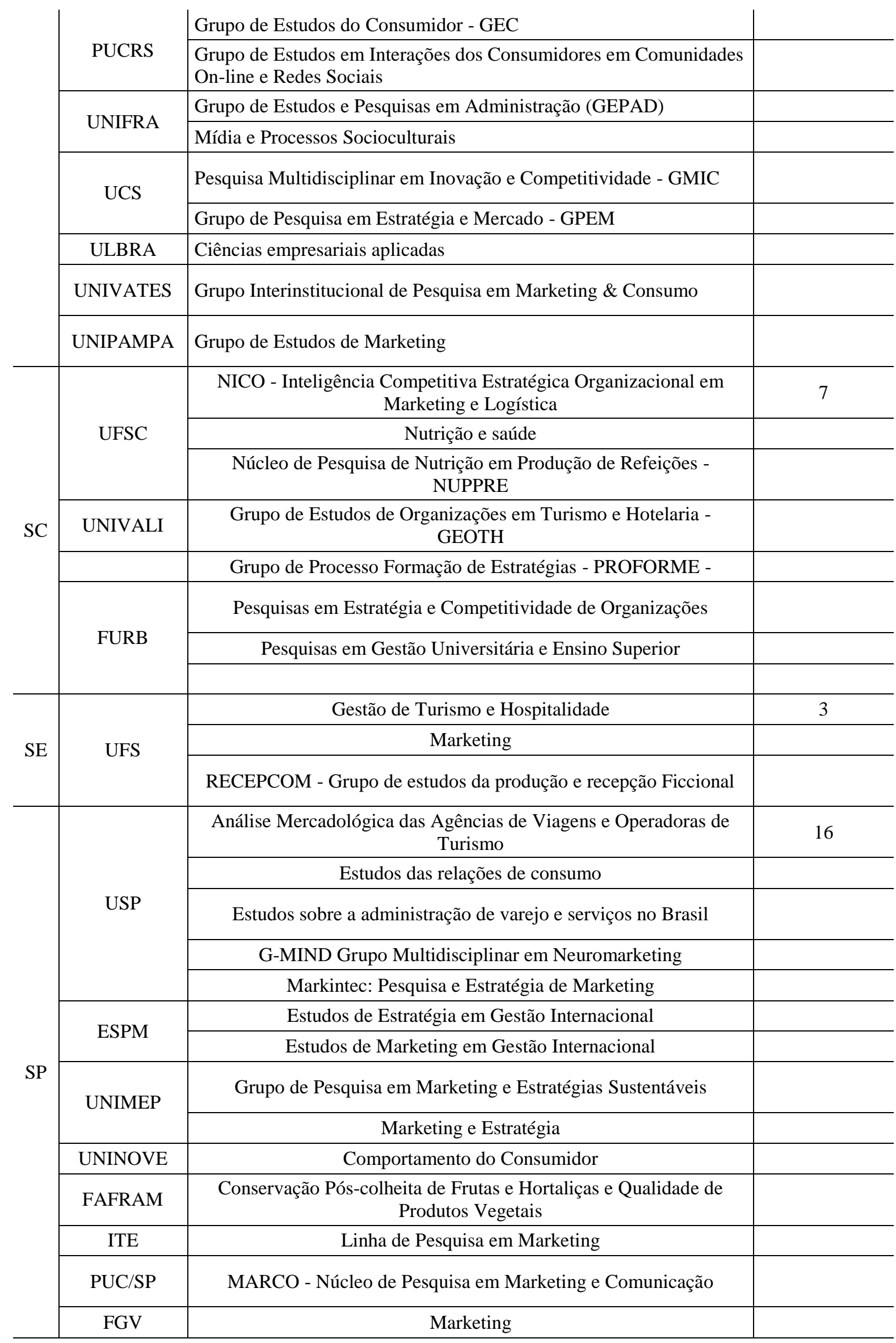




\begin{tabular}{c|c|c|c} 
& UNIARARAS & $\begin{array}{c}\text { Sociedade e Relações Humanas: Tecnologias e Estratégias } \\
\text { Empresariais }\end{array}$ & \\
\cline { 2 - 4 } & UNICAMP & Laboratório de Psicologia Genética & \\
\hline TO & UFT & Desenvolvimento de novos produtos Alimentícios & 1 \\
\hline
\end{tabular}

Fonte: Elaborado pelo autor, com base no Banco de Dados da Plataforma Lattes, do CNPq.

Ao analisar a Tabela 9, percebe-se que a maior parte dos 103 grupos de pesquisa em comportamento do consumidor está localizado no eixo que compreende as regiões sudeste (38 grupos ou 36,9\%) e sul (31 grupos ou 30,1\%), perfazendo 67\% de todos os grupos de pesquisadores. Bem abaixo, encontram-se as regiões nordeste, com 16,5\%, isto é, 17 grupos, centro-oeste com 13,59\%, ou 14 grupos, e, por fim, a região norte, perfazendo $2,91 \%$, ou 3 grupos.

Em seguida, foi pesquisado o pertencimento dos grupos de pesquisa em comportamento do consumidor, de acordo com os critérios classificatórios de grande área de pesquisa. Os resultados estão apresentados na Tabela 13.

Tabela 13

Grupos de pesquisa, de acordo com a grande área de concentração

\begin{tabular}{ccc}
\hline Grande área do grupo & N de grupos de pesquisa & \% de grupos de pesquisa \\
\hline Ciências Agrárias & 5 & $4,81 \%$ \\
Ciências da Saúde & 3 & $2,88 \%$ \\
Ciências Humanas & 5 & $4,81 \%$ \\
Ciências Sociais & $\mathbf{9 0}$ & $\mathbf{8 6 , 5 4 \%}$ \\
Aplicadas & 1 & $0,96 \%$ \\
Linguística, Letras e Artes & 104 & $100,00 \%$ \\
Total & Ban \\
\hline
\end{tabular}

Fonte: Elaborado pelo autor, com base no Banco de Dados da Plataforma Lattes, do CNPq.

Observe-se que a grande maioria dos grupos, quase $87 \%$, é classificada na grande área de pesquisa de Ciências Sociais Aplicadas.

O passo seguinte refere-se ao detalhamento dos grupos de pesquisa da grande área Ciências Sociais Aplicadas, de acordo com a área do grupo, conforme mostrado na Tabela 14. 
Tabela 14

Discriminação dos grupos de pesquisa de acordo as áreas do grupo

\begin{tabular}{ccc}
\hline Área do grupo & $\begin{array}{c}\text { N de grupos de } \\
\text { pesquisa }\end{array}$ & \% de grupos de pesquisa \\
\hline Administração & $\mathbf{7 5}$ & $\mathbf{8 3 , 3 3 \%}$ \\
Comunicação & 4 & $4,44 \%$ \\
Economia & 2 & $2,22 \%$ \\
Economia Doméstica & 1 & $1,11 \%$ \\
Turismo & 8 & $8,89 \%$ \\
Total & 90 & $100 \%$ \\
\hline
\end{tabular}

Fonte: Elaborado pelo autor, com base no Banco de Dados da Plataforma Lattes, do CNPq.

Salienta-se que a área de Administração corresponde a mais de $83 \%$ dos grupos de pesquisa em comportamento do consumidor. A área de Turismo, com quase 9\%, ocupa o distante segundo lugar.

Ponderando que a atividade de pesquisa científica pode ser considerada uma atividade permanente, identificaram-se os grupos de pesquisa que estavam marcados como desatualizados há mais de 12 meses no portal da Plataforma Lattes, conforme apresentado na Tabela 15.

Tabela 15

Grupos de pesquisa da base atual, na área administração, por status de atualização

\begin{tabular}{ccc}
\hline Status da atualização & N de grupos de pesquisa & \% de grupos de pesquisa \\
\hline Atualizado & $\mathbf{6 2}$ & $\mathbf{8 2 , 6 7}$ \\
Desatualizado há mais de 12 & 13 & 17,33 \\
meses & 75 & $100 \%$ \\
Total & & \\
\hline
\end{tabular}

Fonte: Elaborado pelo autor, apoiado na Base Corrente do Diretório dos Grupos de Pesquisa da Plataforma Lattes.

Existiam, portanto, 62 grupos de pesquisa sobre comportamento do consumidor, pertencentes à área de administração, ativos à época do levantamento. O resultado pode ser considerado preocupante, dado que mais de $17 \%$ dos grupos de pesquisa em "comportamento do consumidor" da área de Administração se encontravam desatualizados há mais de 12 meses, quando do levantamento.

O processo de pesquisa sobre a institucionalização acompanhou a evolução dos grupos de pesquisa em comportamento do consumidor, nos censos realizados de dois em dois anos e disponibilizados na Plataforma Lattes. O primeiro censo disponível é o de 2000 e o último é de 2010. Os dados de 2012 ainda não foram publicados na plataforma. A série cronológica constituída de seis levantamentos permite uma aproximação muito rica sobre a 
evolução dos grupos de pesquisa e inclusive sobre a produção em ciência, tecnologia e assessoramento relativo ao comportamento do consumidor.

A primeira busca efetivada tratou da evolução do número de grupos de pesquisa com o uso da expressão "comportamento do consumidor", com as opções "busca exata", "nome do grupo", "nome da linha de pesquisa" e "palavra-chave da linha de pesquisa", selecionadas. Os resultados estão tabulados na figura 13:

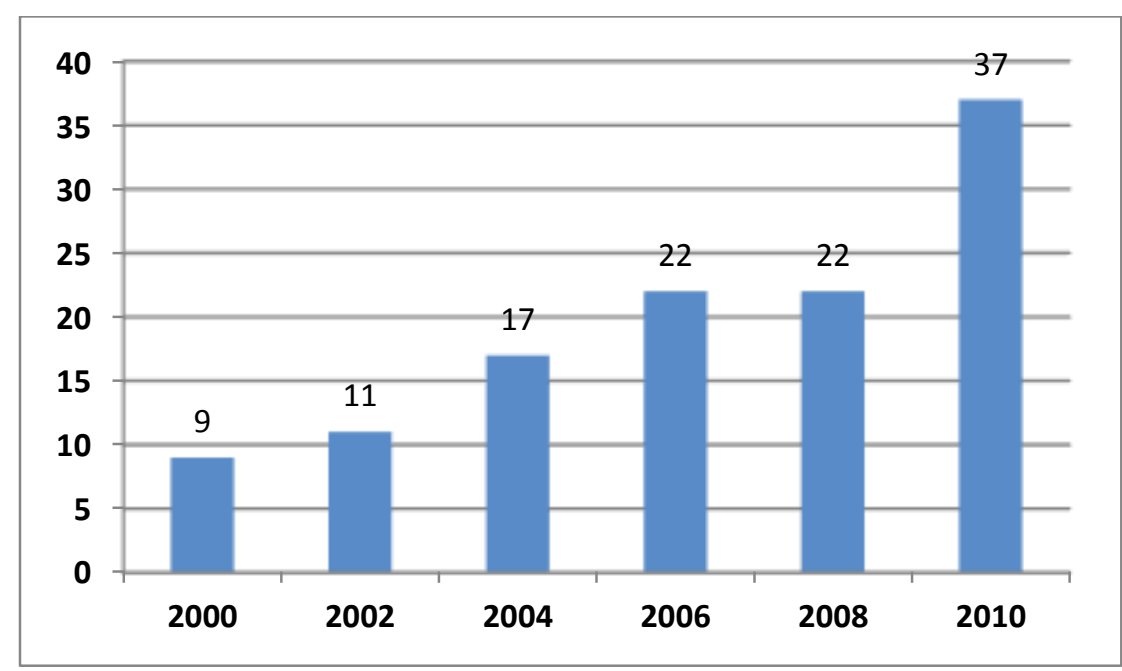

Figura 13. Evolução dos grupos de pesquisa de 2000 a 2010

Fonte: Elaborado pelo autor, com base nos dados dos

Censos do Diretório dos Grupos de Pesquisa, da

Plataforma Lattes.

Observa-se a grande variabilidade na presença dos grupos nos censos. Assim, dos 11 grupos recenseados em 2002, 8 eram novos e só três grupos de 2000 foram recenseados. Dos 17 grupos recenseados em 2004, 5 grupos já haviam sido recenseados em 2000, 4 não mais existiam, 3 já haviam sido recenseados em 2002 e 9 eram novos.

Apenas dois grupos, o de envolvimento social corporativo e proteção ambiental da UFU e o Plural - Moda e Vestuário da UFRPE - participaram dos seis censos. O grupo Empreendedorismo, geração de negócios e nichos de mercado: realidades e perspectivas em Alagoas da UFAL, participou de cinco censos. Seis grupos participaram de quatro censos; sete grupos participaram de três censos e onze grupos participaram de dois censos. Por fim, trinta e dois grupos participaram de apenas um censo.

Assim sendo, de 2000 a 2010, em seis edições, o Censo coletou um conjunto de 117 pacotes de informações sobre os grupos de pesquisa em comportamento do consumidor, que, entretanto, apresentam uma sobrevida bastante limitada.

A busca exata por "comportamento do consumidor", aplicada nos campos "palavrachave da linha de pesquisa" e "nome da linha de pesquisa", nos censos dos grupos de 
pesquisa, permitiu observar a seguinte evolução dos grupos de pesquisa sobre comportamento do consumidor no Brasil, conforme mostrado na figura 14 :

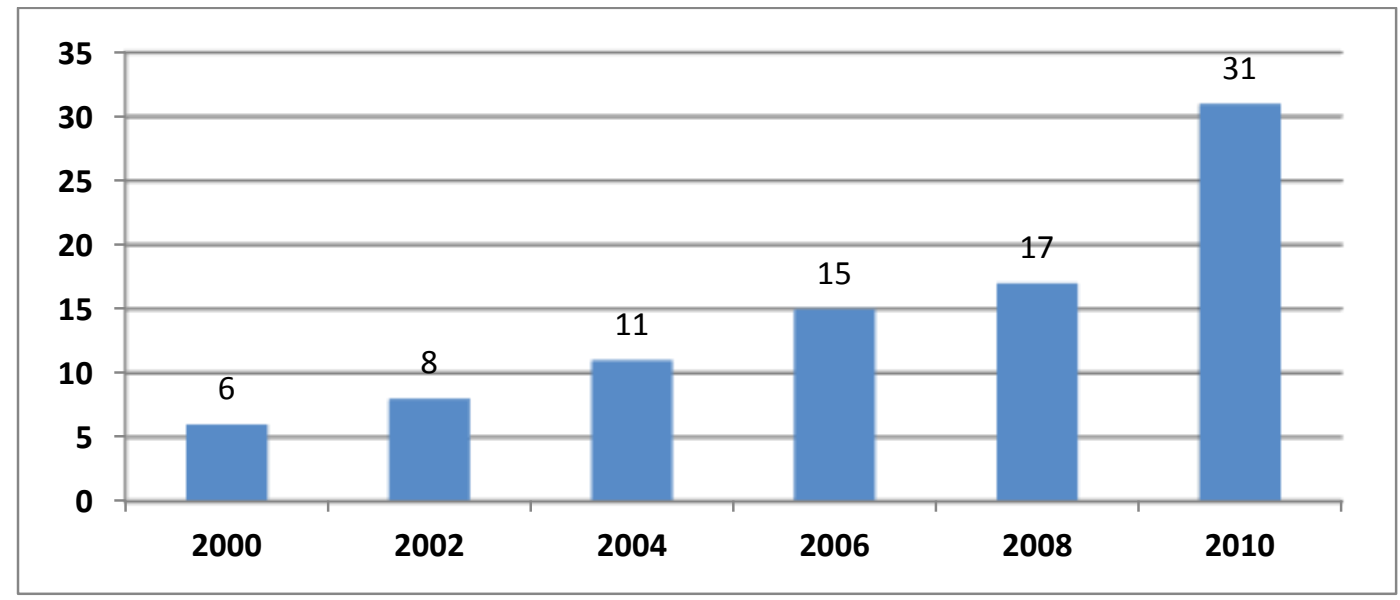

Figura 14. Evolução das Linhas de Pesquisa nos Censos de 2000 a 2010

Fonte: Elaborado pelo autor, a partir dos dados dos Censos do Diretório dos Grupos de Pesquisa, da Plataforma Lattes.

Nota-se da leitura do Gráfico 8 que ocorreu uma explosão no aparecimento de linhas de pesquisa a partir de 2008, culminando com 31 linhas em 2010. Em virtude da evolução da produção científica, da técnica e de assessoramento em comportamento do consumidor, inerente aos grupos de pesquisa, levantou-se o desenvolvimento desse parâmetro nos censos constantes do Diretório de Pesquisa da Plataforma Lattes. A pesquisa por "comportamento do consumidor", busca exata, aplicada aos parâmetros "Referência bibliográfica" e "palavrachave da produção" trouxe os resultados que constam da Figura 15.

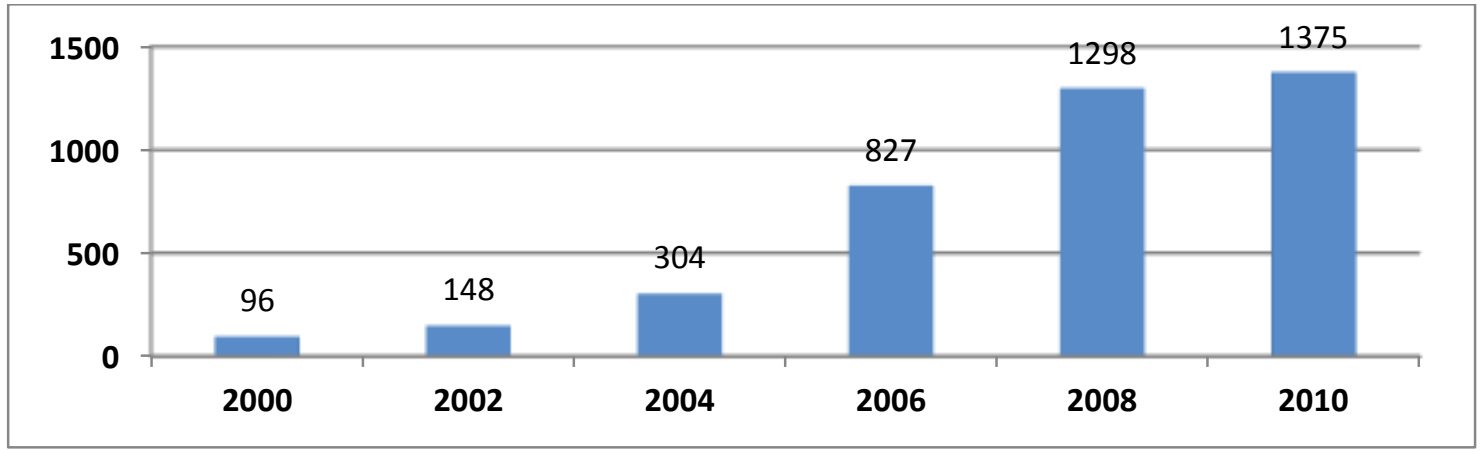

Figura 15. Evolução da Produção C,T\&A nos Censos de 2000 a 2010

Fonte: Elaborado pelo autor, com base nos dados dos Censos do

Diretório dos Grupos de Pesquisa, da Plataforma Lattes.

Entre 2002 e 2006 evidencia-se o crescimento assintótico da produção C,T\&A, superior a $100 \%$ e o provável atingimento de um patamar de uma produção ao redor de um 
número de 1.300 artigos em C,T\&A em 2010. A partir da busca textual "comportamento do consumidor" foi efetuada a identificação de pesquisadores da temática Comportamento do consumidor, baseado no Curriculum Vitae na Plataforma Lattes. Essa pesquisa curricular permite identificar os atores institucionalizados pela busca por assunto (título ou palavrachave da produção).

Divididos em duas categorias (doutores e demais pesquisadores), um total de 5.430 pesquisadores foram relacionados à temática do comportamento do consumidor, dos quais 5.381 são brasileiros e 49 estrangeiros. Em seguida, os pesquisadores foram diferenciados nas duas categorias citadas. Na primeira, constam 1.474 doutores, dos quais 1.447 são de nacionalidade brasileira e 27 de nacionalidade estrangeira, enquanto que a segunda é composta pelos demais pesquisadores (pesquisadores com mestrado, graduação, estudantes e técnicos), que somam 3.956, dos quais 3.934 são de nacionalidade brasileira e 22 de nacionalidade estrangeira.Verificou-se ainda que, entre os 1.474 doutores, 1.079 constavam dos grupos de pesquisa, ao passo que dos 3.956 demais pesquisadores, apenas 934 constavam dos grupos de pesquisa.

Investigou-se, em seguida, um parâmetro de meritocracia do Conselho Nacional de Desenvolvimento Científico e Tecnológico, que consiste na atribuição do comitê acadêmico da área de pesquisa aos pesquisadores com maior produtividade acadêmica, isto é, àqueles portadores de bolsa de produtividade em pesquisa, divididos em níveis (1A, 1B, 1C, 1D e 2). Assim, foram identificados 105 doutores com bolsa de produtividade em pesquisa, dos quais, 10 doutores com bolsa de produtividade em pesquisa 1A; 6 doutores com bolsa de produtividade em pesquisa 1B; 7 doutores com bolsa de produtividade em pesquisa $1 \mathrm{C} ; 22$ doutores com bolsa de produtividade em pesquisa 1D e 60 doutores com bolsa de produtividade em pesquisa 2.

O conjunto de dados apresentados nesta seção corroboram que o comportamento do consumidor é um tema bem identificado no sistema público de pesquisa e desenvolvimento, com grupos de pesquisa, linha de pesquisa e produção em C,T\&A com características próprias. Esta evolução merece estudos mais aprofundados que permitirão fortalecer ainda mais esse segmento e proporcionar oportunidades de avanços de pesquisa que poderão beneficiar sobremaneira a academia e a sociedade brasileiras.

\subsubsection{Discussão e lacunas de Pesquisa}

Com base nas informações alcançadas com essa pesquisa, é possível traçar um 
cenário a respeito da evolução dos estudos sobre comportamento do consumidor no país. Mesmo com o crescimento quantitativo na produção acadêmica no Brasil, fator positivo, determinados pontos necessitam de aprofundada reflexão. Esse crescimento também foi mencionado em recente revisão sobre marketing (Mazzon \& Hernandez, 2013), com o comportamento do consumidor classificado no topo dos temas mais publicados.

Observa-se um interesse pela área na produção nacional dos periódicos da administração de primeira linha, ao longo dos treze anos analisados. Verificam-se duas tendências de aumento: a primeira com início no ano de 2003 até o ano de 2006, sendo que nos anos posteriores (de 2007 a 2009) oscilaram quanto à quantidade de publicações, e a segunda, partir do ano de 2010, que mostra o crescimento na quantidade de publicações no fim da primeira década do milênio. Não obstante, vale ressaltar que as investigações ainda estão fragmentadas, sinalizando que o campo de investigação de comportamento do consumidor está longe de ser consolidado.

O estudo revela também que a concentração de artigos sobre comportamento do consumidor não apenas se manteve alta, mas crescente, como relatado em estudos anteriores de Faria, Oliveira, Lacerda e Lara (2006), Mazzon e Hernandez (2013), Perin, Sampaio, Froemming e Luce (2000), Pinto e Lara (2007), Vieira (2003) e Vieira (2002), com pouco uso de experimentos e frequente uso de pesquisas descritivas e exploratórias. Analisando os trabalhos de comportamento do consumidor publicados no Brasil, somente $8 \%$ deles referemse a delineamentos experimentais, enquanto $50 \%$ dos artigos publicados no Journal of Consumer Research e $23 \%$ dos artigos publicados no Journal of Marketing Research referem-se a experimentos (Tellis, Chandy \& Ackerman, 1999). O avanço da área passa pela aproximação daquilo que é produzido nos principais centros de pesquisa. Para tanto, é imperativo que os autores de comportamento do consumidor diversifiquem os temas de suas pesquisas e invistam mais em delineamentos experimentais, conforme já salientado por Mazzon e Hernandez (2013).

Evidencia-se o predomínio de trabalhos teórico-empíricos. Nesse contexto, a maioria dos artigos é de natureza quantitativa, mesmo encontrando uma relevante quantidade de estudos em que o método qualitativo esteve presente, fato esse também descrito por Mazzon e Hernandez (2013). Esse cenário propicia a abertura de um campo passível de desenvolvimento na área de comportamento do consumidor, com maior produção de estudos híbridos (quali-quanti), destacando-se a necessidade de se elaborar testes em teorias, investigações mais profundas nas relações com comportamentos, atitudes, como forma de se encontrarem resultados mais conclusivos. Conforme se pode constatar, existe uma lacuna nos 
ensaios teóricos, uma vez que representaram apenas 15\% dos estudos nos 13 anos analisados.

Como forma de se avançar nas pesquisas sobre comportamento do consumidor e se aproximar mais das investigações internacionais, os estudos brasileiros vindouros necessitam de investir em análises mais robustas, como por exemplo, a modelagem por equações estruturais e a análise multinível, essa última técnica que investiga a influência de níveis superiores (situacional ou contextual) sobre o nível individual. Contudo, não foi encontrado, no presente levantamento, nenhum estudo que utilizasse esse método de análise de dados. Constatação semelhante foi, novamente, apontada por Mazzon e Hernandez (2013), cujas técnicas de análise empregadas são, corriqueiramente, testes estatísticos e análises multivariadas de primeira geração (teste $t$, regressões simples, ANOVA, entre outras). Técnicas de segunda geração (análise multinível e modelagens por equações estruturais) são pouco frequentes. Conclui esse autor que o alavancador qualitativo da produção futura brasileira deve ser direcionado para a elaboração de estudos que envolvam complementarmente professores e pesquisadores de diferentes instituições.

Cabe ainda às pesquisas brasileiras futuras elaborarem testes de proposições de modelos mais compreensivos que incluam variáveis de contexto, que por sua vez reflitam o compartilhamento das percepções sociais coletivas entre os indivíduos como forma de alcançarem resultados mais fidedignos sobre a influência do comportamento do consumidor nos comportamentos e atitudes dos indivíduos. Resultado importante mostra a diversidade de produção entre as instituições. Mesmo com o predomínio de publicações oriundas de autores da USP, FGV e UFRGS, diversos outros autores pertencentes às mais diferentes instituições começam a produzir. Essa produção pode sinalizar o aumento do número de linhas de pesquisa em comportamento do consumidor, que saíram de apenas 6 em 2000, para 31 em 2010, ou seja, um aumento superior a $516 \%$.

Outro resultado semelhante foi encontrado por Mazzon e Hernandez (2013) e se refere ao número de autores por artigo, com um aumento médio. Entretanto, cabe salientar, que em geral, são autores oriundos da mesma instituição. Igualmente, para a expansão qualitativa da área, deve-se estimular o intercâmbio de pesquisas entre pesquisadores de diferentes instituições, prática recorrente nos mais avançados centros de pesquisa. Por fim, cabe destacar que a produção brasileira reflete a produção gerada internacionalmente, notadamente quando se observam os aspectos teóricos discutidos. Entretanto, cabe uma ponderação sobre o alinhamento entre esses temas e a realidade do Brasil, conforme também sugerido por Mazzon e Hernandez (2013). Para esses autores, a produção brasileira negligencia diversos contextos, entre os quais a pobreza e o consumo, o desenvolvimento de 
produtos e serviços para a nova classe média e para a classe baixa, o endividamento, o comportamento de compra compulsiva etc. Além disso, é preciso um fortalecimento dos aspectos teóricos e metodológicos, sobretudo no delineamento da pesquisa e em termos de técnicas mais sofisticadas de análises de dados, com foco na produção em revistas de maior impacto, como as internacionais. Novamente, a sinergia entre os centros de pesquisas nacionais aparece como uma alternativa para suprir essa lacuna por artigos mais robustos, e somente com o intercâmbio de pesquisadores da área serão alcançadas publicações de maior impacto.

\subsubsection{Conclusões, Contribuições e Limitações do Estudo I}

Como forma de conclusão, este trabalho buscou contribuir para a produção acadêmica sobre comportamento do consumidor ao realizar a revisão de literatura com ênfase na produção nacional recente, abrangendo os últimos 13 anos, e ao recomendar reflexões que propiciassem a construção de uma agenda de pesquisa sobre o tema. Contribuiu, também, por ser um trabalho de compreensão teórica, que preenche uma lacuna da literatura, uma vez que a grande parte dos trabalhos sobre o comportamento do consumidor, como ressaltado no presente capítulo, é teórico-empírica.

Por sua vez, algumas limitações necessitam ser apontadas. Este estudo não pretendeu esgotar a literatura nacional sobre comportamento do consumidor no período investigado, em razão de ter se restringido aos periódicos científicos de nível superior (maior/igual à Qualis B1) da área de Administração. Mais uma omissão encontra-se presente nas análises dos artigos apresentados nos principais congressos, como os EnANPADS, principal encontro da área. Essa opção foi tomada porque os melhores artigos apresentados no congresso são posteriormente publicados em parte dos periódicos ora revisados. Disso resultou a não inclusão de seus anais neste levantamento, tampouco as dissertações e teses dos diversos programas de pós-graduação stricto sensu em Administração do país, durante o período considerado.

Outra lacuna, embora não faça parte do escopo desta publicação, é o levantamento da produção acadêmica realizada por pesquisadores brasileiros e publicada no exterior. Esse trabalho permitiria talvez traçar estudos comparativos de tendências, verificar critérios de aceitação de artigos, tipologias metodológicas etc.Diante do objetivo de exibir o cenário de publicações dos periódicos da área de Administração, e conhecendo a preferência dos psicólogos organizacionais nacionais em direcionar suas publicações para os periódicos da área de administração (Ferreira, Fernandes \& Corrêa-e-Silva, 2009), os periódicos da área de 
psicologia não foram contemplados, bem como as dissertações de mestrado e teses de doutorado em psicologia com clara proximidade temática.

Não obstante as limitações descritas, a avaliação produzida neste capítulo permitiu que fosse realizado um primeiro mapeamento sobre a produção brasileira recente concernente ao comportamento do consumidor. Nesse sentido, os resultados gerados, de fato, apontaram a relevância do construto como instrumento de auxílio aos tomadores de decisão, no sentido de definir objetivos, compreender os significados e as mensagens expressas pela posse de produtos, além de identificar os desejos e expectativas dos clientes, em cada mercado específico. Entretanto, salienta-se a necessidade de mais estudos sobre o tema, principalmente no que se refere ao aprofundamento de modelos teóricos e de relações mais profundas entre distintos construtos. Conforme a revisão elaborada por Vieira (2002), diversas são as áreas influenciadas pelo estudo do comportamento do consumidor, entre as quais, destacam-se atitudinal, cultural, étnica, social e de status, pessoal, familiar e situacional.

O diagnóstico formado permitiu levantar fraquezas teórico-metodológicas que apontam para a necessidade de fortalecimento de parcerias no nível interno e internacional para contribuir para sua superação. Essa cooperação internacional provocaria, inevitavelmente, novas agendas de pesquisas que, se efetivas, deverão refletir, em um momento próximo, a crescente internacionalização da economia brasileira e o comportamento dos consumidores brasileiros, no país e no exterior, do qual o turismo externo brasileiro é um exemplo recente. Diante disso, emergem oportunidades para pesquisas que contemplem testes das teorias já consolidadas e a proposição de novas teorias, modelos e relações entre variáveis que subsidiem as tomadas de decisão e que contribuam para construção de um arcabouço teórico mais consistente. Dessa forma, será possível promover o avanço progressivo do conhecimento teórico-empírico sobre comportamento do consumidor no Brasil.

\subsection{Estudo II - Preferência e Consumo de Automóveis no Brasil e no Mundo}

Este estudo busca apresentar os estudos relativos ao consumo de automóveis no Brasil e em outros países. Foram encontrados 5 artigos que abordam o consumo de automóveis no Brasil e 18 artigos que abordam a temática de preferência ou consumo de automóveis no 
período de 2000 a 2014. Gonçalves Filho, Fernandes, Souki e Dias (2013) apresentaram um estudo que utiliza características internas dos indivíduos para segmentar o mercado automotivo da cidade de Belo Horizonte, em que foram utilizadas diversas escalas psicológicas, incluindo a EVS (Escala de Valores de Schwartz), de Schwartz, (1992). Foram realizadas análises quantitativas como agrupamento e análise de confiabilidade para dividir os segmentos no mercado e foram encontrados sete segmentos de mercado com estilo de vida diferentes.

Porto e Torres (2012) estudaram a preferência por tipo de automóvel utilizando os Valores Humanos pertencentes ao Inventário de Valores Humanos (IVS), de Tamayo e Schwartz (1993), os atributos do produto e as variáveis demográficas. Porto e Torres (2012) adotaram regressões logísticas para vefificar a influência individual dos Valores Humanos e das variáveis demográficas, e encontraram predição para a preferência de diferentes tipos automóveis com tipos motivacionais variados, bem como para a influência de idade, sexo e escolaridade. Norberto (2004), por seu turno, apresenta um artigo teórico acerca das estratégias de diferenciação social por meio das marcas dos automóveis. Norberto (2004) salienta a representatividade da marca como signo, evocando representações partilhadas, simbólicas e econômicas que funcionam como dispositivos sociais de construção de identidade. Torres e Allen (2009) realizaram um estudo sobre Valores Humanos, comparando a preferência de automóvel aplicando o julgamento afetivo e o julgamento passo a passo entre Brasil e Austrália. Foram feitas regressões para verificar em qual país cada tipo de julgamento era melhor predito indicando que, no Brasil, o julgamento de automóveis é predominantemente afetivo através da rota direta, enquanto na Austrália o julgamento é predominantemente passo a passo utilizando a rota indireta de julgamento por intermédio dos atributos tangíveis dos automóveis. Jato e Licht (2009) estudaram a diferença entre homens e mulheres na preferência por automóveis. Foi feito um estudo qualitativo para determinar quais itens eram citados como imporantes por homens e mulheres em um automóvel e os listaram em ordem de preferência, apontando a inexistência de diferença na preferência dos itens presentes em um autómóvel em diferentes sexos.

Considerando os artigos com estudos realizados fora do Brasil, Vrkljan e Anaby (2011) verificaram a importância dos atributos do veículo em diferentes idades e sexos. Para tanto, realizaram ANOVAS para comparar o nível de importância dos atributos do automóvel em diferentes idades e entre homens e mulheres, indicando que segurança e e confiabilidade foram os itens de maior importância e idade e sexo influenciam a importâcia entre os atributos. 
Qian e Soopramanien (2014) verificaram a preferência do mercado chinês quanto ao tipo de combústivel, alternativo ou à base de petróleo, dos consumidores de automóveis. Ao adotar regressões logísticas, os autores indicaram que a prefência por automóveis é influenciada pelo tipo de combustível, existindo predileção por automóveis que utilizem métodos alternativos de energia. Qian e Soopramanien (2014) conduziram outro estudo no mercado chinês para determinar as características que estudam o consumo de automóveis movidos a métodos alternativos de energia. Mediante as correlações entre as características pesquisadas, preço, duração da bateria, preço do combústivel convencional e distância coberta pelo carro, os autores traçaram cenários futuros apontando que o barateamento das tecnologias de consumo alternativas bem como o encarecimento do combustível convencional indicam aumento da porcentagem dos automóveis, que empregam métodos alternativos de energia e híbridos e, por consequência, diminuição da quantidade de automóveis que utilizam petróleo como combustível.

Estudo similar foi conduzido por Koetse e Hoen (2014) que verificaram, na Holanda, a preferência de empresas entre automóveis que utilizam métodos alternativos comparados com os que utilizam métodos convencionais de energia. Ao aplicar regressões logísticas lineares, os autores sugerem que empresas preferem o método convencional de energia, enquanto o usuário privado prefere métodos alternativos de energia para automóveis. Considerando ainda o mercado holandês, Van Rijnsoever, Farla e Disjt (2009) estudaram a preferência declarada e o tipo de informação buscada no processo de compra de automóveis. Para satisfazer os objetivos da pesquisa, aplicaram análise de conglomerado, comparando o atributo de preferência com a informação buscada pelo consumidor. Os autores verificaram que a preferência declarada somente se agrupava com a fonte de informação referente àquela preferência no caso de consumidores altamente envolvidos com o cuidado com o meio ambiente, encontrando discrepância entre o que o consumidor procura e o que declara que prefere, em consumidores de baixo envolvimento.

No mercado alemão, Hackbarth e Madlener (2013) verificaram somente as características do mercado privado de compradores de automóveis quanto ao tipo de perfil que prefere automóveis que utilizam métodos alternativos de energia. Os autores efetuaram regressões logísticas e observaram que, no mercado alemão, o grupo de pessoas mais sensível à adoção de automóveis movidos a métodos alternativos de energia são jovens com alto nível de educação e com consciência ecológica. Também considerando o mercado alemão, Franke e Krems (2013) verificaram a preferência de automóveis elétricos entre consumidores de automóveis e, utilizando regressões, observaram que, quanto maior a distância que o usuário 
dirige, menor sua predileção por automóveis elétricos. Também indicaram que consumidores que testaram automóveis elétricos são mais favoráveis à compra dos mesmos.

Caulfield, Farrel e McMahon (2010) elaboraram um estudo sobre preferência de consumo de automóveis movidos a métodos de energia alternativos e híbridos, na Irlanda. Para atingir os resultados da pesquisa, os autores questionaram os respondentes acerca da importância do impacto no meio ambiente, custo do combustível, confiança, custo do automóvel e segurança, comparando as médias de respostas e, servindo-se de tabulações cruzadas, concluiram que os atributos mais importantes nos automóveis para a amostra pesquisada, no mercado Irlandês, é confiança, segurança, custo do combustível e preço do automóvel, indicando também que nos próximos 10 anos tanto o automóvel híbrido como o de combustível alternativo seriam a escolha no momento da compra.

$\mathrm{Wu}$, Liao e Chatwuthikrai (2014) consideraram o mercado em Taiwan a respeito do julgamento dos indivíduos com relação a carros super compactos. Os autores argumentam que os consumidores tendem a avaliar as características em conjunto em vez de separadaramente; então, aplicaram análise de conglomerado concluindo que aparência é a característica mais importante na avaliação do automóvel, seguida de autonomia, preço e segurança. Potência de motor e opcionais tecnológicos figuraram entre os menos importantes. Chiu, Cheng, Yen e Hu (2011), em estudo anterior, também pesquisaram o mercado taiwanês para investigar elementos de satisfação e lealdade na pós-compra de automóveis. Os autores aplicaram questionários a consumidores que adquiriram automóveis junto a uma concessionária, entre 2006 e 2008, e por meio de modelagem por equações estruturais constataram que $48 \%$ da lealdade é explicada pela satisfação do cliente, e a satisfação é explicada $15 \%$ pela imagem e $70 \%$ pela percepção da qualidade.

Baltas e Saridakis (2013) averiguaram o impacto de características comportamentais e psicológicas na preferência de carros, no Reino Unido. Utilizando regressões logísticas multinominais, verificaram que variáveis como propósito do carro, fonte de informação adotada antes da compra, propensão do consumidor em adquirir um carro ecológico, envolvimento com automóveis, e apego por carros alteram significativamente o tipo de carro escolhido. No mercado espanhol, Moral e Jaumandreu (2007) atestaram a influência do modelo do automóvel, os atributos do veículo e o tempo de posse do produto, na percepção de preço e velocidade de troca. Para por em prática o estudo, recorreram a regressões logísticas e indicaram que, nos três primeiros anos de lançamento do automóvel, a fatia de mercado tende a aumentar e depois começa a diminuir, ao longo do tempo, o incremento de atributos do automóvel e a diminuição do preço tendem a aumentar a presença do produto no 
mercado. Siren e Haustein (2013) observaram a frequência e a preferência na utilização de automóveis, em função de sua idade, no mercado dinamarquês. Aplicaram análise de agrupamento, observando a flexibilidade, independência e restrição dos idosos, nascidos entre 1945 e 1960, com os mais jovens, quanto à utilização de automóveis. Os autores verificaram que nascidos entre 1945 e 1960, na Dinamarca, utilizam muito mais automóveis e são muito mais restritos a eles do que os mais jovens.

Em estudo conferiu os critérios de escolha de automóveis de idosos Zhan, Porter, Polgar e Vrkljan (2013) analisaram o mercado canadense quanto à importância de segurança, preço, autonomia de combustível e conforto. Os autores se valeram de trinta e três respondentes, com idades entre 70 e 87 anos, organizados em seis grupos de foco e verificaram que consumidores idosos possuem lacunas a respeito do entendimento dos atributos de segurança do automóvel, considerando todos os automóveis disponíveis no mercado como seguros, que preço conjuntamente com autonomia de combustível desempenham papel marcante na escolha do automóvel.

Gabor e Contiu (2012) estudaram o mercado para o automóvel, na Romênia, a respeito da preferência dos jovens acerca da marca do carro e a influência das campanhas de divulgação na escolha. Os autores utilizaram testes não paramétricos, teste de friedman, correlações de Kendall e Spearman, teste Mann-Whitney, Kruskal-Wallis, KolmogorovSmirnov e qui-quadrado e constararam que o meio de divulgação que gera maior influência nos jovens é a televisão bem como a universidade em que estudaram; o tempo de educação formal, a especialização e o gênero influenciam a marca escolhida.

No mercado francês, Kergoat, Giboreau, Nicod, Faye, Diaz, Beetschen, Gerritsen e Meyer (2010) investigaram a influência de variáveis psicológicas e sensoriais na escolha de material do banco de assentos de automóveis. Os autores fizeram duas análises de conglomerado, uma com um grupo que prefere assento de veludo e outra com os que não o preferem, e verificaram que os que prefererem assento aveludado experienciaram as emoções em contato com o assento mais fortemente, enquanto os que não preferem assento aveludado julgaram suas preferências de modo mais sentimental.

\subsubsection{Conclusões do Estudo II}

Observa-se a presença de estudos relativos a consumo de automóveis, em diferentes mercados internacionais, nota-se uma ocorrência superior em estudos sobre combustíveis alternativos e sua influência no consumo; tal ocorrência é concomitante com o aumento do 
oferecimento de automóveis que utilizam métodos alternativos de energia. Outro achado pertinente é a inexistência de estudos que comparam o consumo de automóveis em países diferentes. Os artigos estudados concentraram-se em compreenderas diferenças dentro do mercado, mas nenhum buscou verificar características que ocorressem entre segmentos.

Estudos relativos à idade foram encontrados em alguns artigos com resultados significativos; porém, outros estudos que utilizaram a variável idade não reportaram achados relativos a essa variável. Somente um dos estudos utilizou modelagem por equações estruturais e a maioria baseou-se em regressões logísticas; acredita-se que essa predominância se deva ao tipo de área que publicou o periódico. Como não foram feitas restrições de áreas, no estudo 2 , a maior ocorrência de revistas com estudos de consumo de automóvel foram periódicos das áreas de economia e transporte.

Após a apresentação da literatura sobre o tema e o estado da arte referente a comportamento e consumo e consumo de automóveis, faz-se necessário relatar como a presente pesquisa será operacionalizada. Para tanto, a seguir, é apresentado o método utilizado para alcançar os objetivos propostos.

\section{MÉTODO}

\subsection{Contexto da pesquisa}

Esta sessão propõe-se a descrever os métodos empíricos empregados no presente estudo, visando identificar e comparar as características dos indivíduos no que tange aos aspectos psicológicos, pretendendo investigar a relação entre idade e os respectivos Valores 
Humanos, Valores Pessoais, Tipo de Julgamento e Atribuição de Significado a um produto para a escolha de automóvel no Brasil e nos Estados Unidos da América.

\subsection{Natureza da pesquisa}

Este estudo é de natureza quantitativa. Acredita-se que com métodos quantitativos mais avançados como a estatística paramétrica multivariada, pode-se mostrar e mapear com mais rigor (exatidão) a influência da idade e dos Valores Humanos e Pessoais no julgamento e atribuição de significado na compra de automóveis. Laville e Dionne (1999) afirmam que, ao lidar com números, busca-se a objetividade e a validade do conhecimento construído. Esta estratégia foi implantada pelo método survey ou levantamento, baseado em questionários estruturados e padronizados. No Brasil, os questionários foram coletados pessoalmente por meio de formulários de resposta impressos em papel. Nos Estados Unidos da América, o instrumento foi aplicado online através do website Mturk (Mechanical Turk). Buhrmester, Kwang e Goslin, (2011), Paolacci, Chandler e Ipeirotis, (2010) realizaram testes com amostras obtidas por meio do Mturk e indicaram que as amostras são melhores que as amostras obtidas pessoalmente, devido à sua variabilidade de respondentes, portanto, gerando melhor representatividade do fenômeno estudado.

\subsection{População}

Em função de o modelo a ser testado consistir na influência da idade e dos Valores Humanos e Pessoais no julgamento e atribuição de significado para a compra de automóveis, no Brasil e Estados Unidos da América, a população do estudo consistiu em usuários de automóveis que possuíam o produto, portanto, limitando a pesquisa a brasileiros acima de 18 anos e estadunidenses acima de 16 anos.

\subsection{Amostra}

No intuito de se estabelecer a amostra de pesquisa necessária para atender aos objetivos do estudo, utiliza-se o método de Cohen (1992) e seu poder, que apontam que $\mathrm{w}=$ 0,10 significa baixo efeito (effect size ), $\mathrm{w}=0,25$ significa médio efeito e $\mathrm{w}=0,40$ representa alto efeito em testes de comparação de médias. Observando as recomendações de Cohen (1992) para estudos dessa natureza, sugere-se empregar efeitos médios ( $\mathrm{w}=0,25)$, com nível de significância de 0,05 e poder estatístico desejado de 0,80 .

Assim, para o teste de comparação de médias de mais de 2 grupos (ANOVA), recomenda-se obter dados de 52 indivíduos para cada grupo o que significa amostra total de 
104 indivíduos. No entanto, Cohen (1992) aponta que para a regressão múltipla com 8 variáveis independentes a amostra é de 107 indivíduos. Tanto a amostra para a ANOVA quanto para a regressão múltipla limitada a 8 variáveis independentes podem ser observadas na tabela 16.

Tabela 16

Tamanho de amostras para efeitos pequenos, médios e grandes com poder estatístico de $0,80 \operatorname{para} \alpha=0,01 \alpha=0,05$ e $\alpha=0,1$

\begin{tabular}{cccccccccc}
\hline \multicolumn{10}{c}{$\alpha$} \\
\hline Teste & 0,01 & 0,05 & 0,1 & 0,01 & 0,05 & 0,1 & 0,01 & 0,05 & 0,1 \\
\hline Teste-T & Pequeno & Médio & Grande & Pequeno & Médio & Grande & Pequeno & Médio & Grande \\
Sigr & 586 & 95 & 38 & 393 & 64 & 26 & 310 & 50 & 20 \\
Rdif & 1163 & 125 & 41 & 783 & 85 & 28 & 617 & 68 & 22 \\
& 2339 & 263 & 96 & 1573 & 177 & 66 & 1240 & 140 & 52
\end{tabular}




$\begin{array}{cccccccccc}\begin{array}{c}\mathrm{P}=.5 \\ \text { Pdif }\end{array} & 1165 & 127 & 44 & 783 & 85 & 30 & 616 & 67 & 23 \\ \text { Qui-Quadrado } & 584 & 93 & 36 & 392 & 63 & 25 & 309 & 49 & 19 \\ 1 \mathrm{gl} & 1168 & 130 & 38 & 785 & 87 & 26 & 618 & 69 & 25 \\ 2 \mathrm{gl} & 1388 & 154 & 56 & 964 & 107 & 39 & 771 & 86 & 31 \\ 3 \mathrm{gl} & 1546 & 172 & 62 & 1,09 & 121 & 44 & 880 & 98 & 35 \\ 4 \mathrm{gl} & 1675 & 186 & 67 & 1194 & 133 & 48 & 968 & 108 & 39 \\ 5 \mathrm{gl} & 1787 & 199 & 71 & 1293 & 143 & 51 & 1045 & 116 & 42 \\ 6 \mathrm{gl} & 1887 & 210 & 75 & 1362 & 151 & 54 & 1113 & 124 & 45 \\ \text { ANOVA } & 586 & 95 & 38 & 393 & 64 & 26 & 310 & 50 & 20 \\ 2 \mathrm{~g} 1 & 464 & 76 & 30 & 322 & 52 & 21 & 258 & 41 & 17 \\ 3 \mathrm{~g}^{1} & 388 & 76 & 30 & 322 & 52 & 21 & 258 & 41 & 17 \\ 4 \mathrm{~g}^{1} & 336 & 63 & 25 & 274 & 45 & 18 & 221 & 36 & 15 \\ 5 \mathrm{~g}^{1} & 299 & 55 & 22 & 240 & 39 & 16 & 193 & 32 & 13 \\ 6 \mathrm{~g}^{1} & 271 & 49 & 20 & 215 & 35 & 14 & 174 & 28 & 12 \\ 7 \mathrm{~g}^{1} & 698 & 44 & 18 & 195 & 32 & 13 & 159 & 26 & 11\end{array}$

Regressão múltipla

$\begin{array}{lcccccc}2 \mathrm{k}^{2} & 780 & 97 & 45 & 481 & 67 & 30 \\ 3 \mathrm{k}^{2} & 841 & 108 & 50 & 547 & 76 & 34 \\ 4 \mathrm{k}^{2} & 901 & 118 & 55 & 599 & 84 & 38 \\ 5 \mathrm{k}^{2} & 953 & 126 & 59 & 645 & 91 & 42 \\ 6 \mathrm{k}^{2} & 998 & 134 & 63 & 686 & 97 & 45 \\ 7 \mathrm{k}^{2} & 1039 & 141 & 66 & 726 & 102 & 48 \\ 8 \mathrm{k}^{2} & 1039 & 147 & 69 & 757 & 107 & 5\end{array}$

Fonte: Cohen (1992), ANOVA = Análise da variância, ${ }^{1}$ grupos, ${ }^{2}$ número de variáveis independentes.

Uma vez que o modelo teórico pressupõe a utilização de mais de oito variáveis independentes, o software $G^{*}$ Power 3.1 .3 foi utilizado para calcular a amostra necessária. Adotando os parâmetros recomendados por Cohen (1992) de poder estatístico de 0,80, $\alpha=$ 0,05 e incluindo as dezenove variáveis independentes, advindas do modelo teórico, obteve-se uma amostra de 147 indivíduos da população em geral. No entanto Hair et al. (2009) argumentam que, no caso de usar a regressão do tipo passo a passo, é necessário balizar a amostra pela quantidade de variáveis independentes presentes no modelo da regressão multiplicado por 10. Assim, devido ao fato de a maior escala possuir 19 construtos, 190 respondentes para cada um dos países estudados satisfaria a amostra mínima para o estudo.

Foram coletados, no Brasil, 585 questionários respondidos e 465 nos Estados Unidos da América. Após o tratamento dos dados, eliminando-se outliers univariados e multivariados, conforme as recomendações de Hair et al. (2009), restaram 565 questionários válidos no Brasil e 450 nos Estados Unidos da América. Utilizando o software ${ }^{*}$ Power 3.1.3 e computando o poder da amostra em função dos questionários coletados, obteve-se 
poder estatístico de 1,0 para ambas as amostras, levando em consideração as 19 variáveis independentes da maior escala presente no instrumento.

A amostra brasileira compreendeu indivíduos entre 18 e 72 anos (Média=40,6 e desvio padrão=9,7); 49,1\% com rendimento acima da média brasileira; 79\% dos indíviduos estava cursando nível superior ou já possuia graduação e 55\% deles eram homens. A amostra estadunidense foi composta por indivíduos entre 16 e 86 anos (Média=42,2 e desvio padrão= 11,8); 49,1\% possuiam renda acima da média, 80\% estavam cursando nível superior ou já possuíam nível superior completo e 52\% deles eram homens.

\subsection{Instrumentos}

Foram aplicadas 3 escalas para compor o modelo geral da pesquisa. A primeira delas teve o intuito de mensurar os Valores Pessoais dos respondentes em diferentes idades - a escala LOV (List of Values) - de Kahle (1983), composta por nove itens representando nove valores:
1) Pertencer a um grupo
2) Excitação
3) Relações amigáveis
4) Satisfação pessoal
5) Ser bem respeitado
6) Diversão e prazer na vida
7) Segurança
8) Amor próprio
9) Realização pessoal

Kahle e Kennedy (1988) apontam que cada item representa um valor em si, e Tomanari (2003) salienta que a escala LOV pode ser aplicada de diversas maneiras, seja escolhendo 2 valores mais importantes, classificando-os em escalas tipo Likert, seja classificando os valores em ordem de importância. $\mathrm{Na}$ atual pesquisa, será adotada a métrica original, proposta por Kahle e Kennedy (1988), que varia de 0 a 10, sendo 0 pouco importante e 10 muito imporante. Kahle e Kennedy (1988) argumentam que, devido ao fato de os Valores Pessoais pertecenrem a uma estrutura universal de todos os seres humanos, uma escala com maior amplitude se faz necessária.

Foi utilizada a escala de Valores Humanos PVQ-R (Portrait Values Questionnaire) (Schwartz et al., 2012; Torres, Schwartz \& Nascimento, 2014), no intuito de verificar sua 
capacidade de predizer os Tipos de Julgamento e Atribuição de Significado no Modelo de Duas Rotas. Allen (1997) juntamente com a escala LOV e também de modo independente, uma vez que o Modelo de Duas Rotas prevê a predição do Significado Afetivo de modo direto pelos Valores Humanos e do Significado Utilitário de modo indireto, utilizando como mediador os atributos tangíveis do produto. Schwartz et al., (2012) utilizam a escala tipo Likert em sua amplitude original, variando em 6 pontos, que questiona o respondente sobre quanto aquela pessoa se parece com ele desde "Não se parece nada comigo" até "Se parece muito comigo".

Schwartz et al. (2012) listam os 19 tipos motivacionais de sua escala, já validada nos

Estados Unidos da América, conforme descritos na tabela a seguir com suas siglas no modelo; a escala foi validada por Torres, Schwartz e Nascimento (2014), no Brasil, com seus respectivos alfas de Cronbach descritos na tabela 17.

Tabela 17

Tipos motivacionais dos Valores Humanos no Brasil

\begin{tabular}{cc|c|c}
\hline Sigla & Tipo motivacional & Valor Humano & \multirow{2}{*}{ Alfa de Cronbach } \\
\cline { 1 - 2 } SDT & Autodireção de Pensamento & & \\
\cline { 1 - 2 } DAS & Autodireção de Ação & & \multirow{2}{*}{ Abertura à Mudança } \\
\cline { 1 - 2 } ST & Estimulação & & \\
\cline { 1 - 2 } HE & Hedonismo & Autopromoção & 0,89 \\
\cline { 1 - 2 } AC & Realização & & 0,88 \\
\hline POD & Poder de Domínio & \\
\hline
\end{tabular}




\begin{tabular}{|c|c|c|c|}
\hline POR & Poder sobre Recursos & & \\
\hline FAC & Face & & \\
\hline SES & Segurança Social & \multirow{6}{*}{ Conservação } & \multirow{6}{*}{0,85} \\
\hline SEP & Segurança Pessoal & & \\
\hline TR & Tradição & & \\
\hline COR & Conformidade com Regras & & \\
\hline COI & Conformidade Interpessoal & & \\
\hline HUM & Humildade & & \\
\hline BEC & Conformidade com Regras & \multirow{5}{*}{ Autotranscendência } & \multirow{5}{*}{0,83} \\
\hline BED & Benevolência Cuidado & & \\
\hline UNC & Universalismo Compromisso & & \\
\hline UNN & Universalismo Natureza & & \\
\hline UNT & Universalismo Tolerância & & \\
\hline
\end{tabular}

Fonte: Schwartz et al. (2012)

Finalmente, para completar o Modelo de Duas Rotas, faz-se necessário avaliar o Tipo de julgamento e a Atribuição de Significado ao automóvel em diferentes países e, para tanto, será aplicada a escala de julgamento e significado de Allen (1997), adaptada e validada para o Brasil, inicialmente por Nepomuceno e Torres (2005), que encontraram somente dois fatores, dos quatro fatores propostos por Allen (1997). Já Alfinito, Nepomuceno e Torres (2012) obtiveram a solução composta por 20 itens distribuídos em quatro fatores, como apontados por Allen (1997); portanto, foi utilizada a escala validada por último, pois se assemelha às proposições de Allen (1997). A tabela 18 apresenta os Tipos de Julgamento e Atribuição de Significado com seus respectivos alfas de Cronbach encontrados por Alfinito, Nepomuceno e Torres (2012) na validação confirmatória da escala e as siglas utilizadas na montagem do modelo estrutural:

Tabela 18

Tipos de Julgamento e Atribuição de Significado

\begin{tabular}{cccc}
\hline Sigla & Fator & Número de Itens & Alfa de Cronbach \\
\hline JS & Julgamento simbólico & 5 & 0,74 \\
\hline JPP & Julgamento passo a passo & 6 & 0,81 \\
\hline SU & Significado utilitário & 3 & 0,78 \\
\hline SS & Significado simbólico & 6 & 0,81 \\
\hline
\end{tabular}

Fonte: Alfinito, Nepomuceno e Torres (2012) 
O instrumento de pesquisa conta com 86 itens das 3 escalas descritas acrescido de questões demográficas referentes à idade, sexo, à renda e ao nível educacional, totalizando 90 questões.

\subsection{Procedimentos}

Foi aplicada a escala tipo likert e, respeitando suas métricas originais, os respondentes dispuseram, em média, de 10 minutos para responder todoo questionário. Os dados foram analisados, utilizando o SPSS 19,0 (Statistical Package for Social Sciences). Para aplicar as técnicas de estatística multivariada como testes-t, regressões lineares múltiplas e modelagem por equações estruturais Tabachnick e Fidell (2001), Hair et al. (2009) e Field (2009) recomendam que seja realizada uma análise prévia dos dados para verificar a existência de discrepâncias nas médias e nos desvios padrão. Seguindo as recomendações de Tabachnick e Fidell (2001), as variáveis foram checadas quanto à sua distribuição de normalidade. Considerando em particular as regressões lineares múltiplas e as recomendações de Miles e Shevlin (2001), linearidade, homocedasticidade e independência de resíduos foram verificados. Miles e Shevlin (2001) indicam que multicolinearidade e singularidade poder sem detectados caso o VIF (Variance Inflation Factor) esteja acima de 2,0 e a tolerância próxima de zero. O maior valor VIF encontrado entre todas as variáveis independentes das regressões lineares múltiplas foi 1,5 e a menor tolerância encontrada foi de 0,75 indicando que esses requisitos não foram violados.

Foi rverificada a correlação entre as variáveis presentes no estudo para indicar, de modo exploratório, a relação de cada uma com as demais, uma vez que o estudo é exploratório e atende às três razões, pelas quais Babbie (1986) aponta que um estudo exploratório é realizado: satisfazer o desejo por melhor entendimento das variáveis do estudo e suas relações, para testar a viabilidade de aprofundamento nos métodos de estudo e, finalmente, para desenvolver métodos a serem utilizados em estudo mais avançado. Para comparar o Tipo de Julgamento predominante em cada um dos países, seguiu-se a recomendação de Field (2009), que aponta que o teste mais indicado é o teste-t de student, que verifica se as médias entre dois grupos são significativamente diferentes.

Para averiguar a predição dos Tipos de Julgamento e Atribuição de Significado pelos Valores Humanos ou Pessoais foram seguidos os passos de Allen (2000) e Torres e Allen (2009), que utilizaram regressões lineares múltiplas com método de entrada de variáveis do tipo enter, no Brasil e nos Estados Unidos da América. Field (2009) aponta que essa regressão é adotada quando se quer verificar o poder explicativo das variáveis independentes 
em grupo frente à variável independente. Assim, foi investigado o poder de predição dos Valores Humanos frente aos Tipos de Julgamento e Atribuição de Significado, o poder de predição dos Valores Pessoais frente aos Tipos de Julgamento e Significado e, por fim, Valores Humanos Conjuntamente aos Valores Pessoais para predizer os Tipos de Julgamento e Atribuição de Significado. Essa comparação foi aplicada para verificar a parcimônia do modelo, uma vez que Valores Humanos e Valores Pessoais pertencem essencialmente a uma estrutura psicológica equivalente.

Em seguida, analisou-se o poder preditivo de modo discriminado dos Valores Humanos e da idade frente aos Tipos de Julgamento e Atribuição de Significado, em ambos os países. Para tanto, as variáveis foram inseridas nas regressões utilizando o método Stepwise. Marôco (2011) aponta que a vantagem deste método é permitir a remoção de uma variável, cuja importância no modelo é reduzida pela adição de novas variáveis; esse método termina quando nenhuma das variáveis indepentes consegue entrar no modelo baseado no valor do F de entrada e nenhuma das variáveis independentes presentes no modelo é expulsa pelo valor do F de remoção. Marôco (2011) salienta que o método Stepwise é particularmente apropriado quando existem correlações significativas entre as variáveis independentes, o que foi verificado por Torres, Schwartz e Nascimento (2014) com relação aos Valores Humanos em sua validação da escala PVQ-R (Schwartz et al., 2012).

Foram elaboradas as análises fatoriais confirmatórias (AFC) da escala de Julgamento e Significado (Allen, 1997) e dos tipos motivacionais que compõe a escala Valores Humanos (Schwartz et al., 2012), que foram significativos nas regressões Stepwise como requisito antecedente à modelagem por equações tal como indica Marôco (2011) pois é considerado como um modelo de medida que antecede a avaliação por equações estruturais.

Marôco (2011) recomenda que, no âmbito da AFC, seja realizada análise de validade convergente, ou seja, que demonstre quando o construto sob avaliação se correlaciona positiva e significativamente com outros construtos teoricamente paralelos e quando os itens que constituem o constrtuto apresentam correlações positivas e elevadas entre si, ou seja, os itens que são reflexos de um fator saturam fortemente esse fator e o comportamento dos itens são explicados essencialmente por esse fator. Marôco (2011) também aponta que a análise da validade discriminante também se faz necessária, uma vez que ela ocorre quando o construto estudado não se encontra correlacionado com construtos que operacionalizam fatores diferentes. Assim, tanto a validade discriminante quanto a convergente foram calculados calculadas para todos os construtos que compuseram o modelo, a saber, os Tipos de 
Julgamento, Atribuição de Significado e os Tipos Motivacionais que foram significativos nas regressões Stepwise.

Foram testadas as relações entre os tipos motivacionais da escala de valores humanos PVQ-R (Schwartz et al., 2012; Torres, Schwartz \& Nascimento, 2014) e o tipo de julgamento, conforme as proposições de Allen (2000) sobre o Modelo de Duas Rotas, que propõe que os Valores Humanos se relacionem, de modo indireto, com o Julgamento Passo a Passo por intermédio dos atributos tangíveis do produto. Assim, foram realizadas três regressões lineares simples para cada amostra, a brasileira e a estadunidense; a primeira empregando o tipo motivacional significativo nas regressões Stepwise prévias como variável independente; e o Julgamento Passo a Passo como variável dependente, a segunda aplicando os atributos tangíveis do automóvel como variável independente e o Julgamento Passo a Passo como variável dependente; e a última, verificando a predição dos atributos tangíveis do automóvel pelo mesmo tipo motivacional utilizado na primeira regressão, assim, verificando se a relação direta é mais forte ou mais fraca do que a relação indireta por meio dos atributos tangíveis do veículo.

Uma vez que se busca analisar as influências dos Valores Humanos e da idade frente aos Tipos de Julgamento e Atribuição de Significado, assume-se a possibilidade de um modelo teórico-conceitual a ser testado. A pesquisa procedeu ainda à modelagem por equações estruturais (Structural Equations Modeling - SEM) para testar a confiabilidade de tal modelo e, logo, sair de um mero teste exploratório (provido pela análise fatorial PAF) para uma ferramenta estatística, que mais se aproxima de um teste de causalidade. Tal demanda, de se sair da análise correlacional para um modelo causal, já é comum na literatura de comportamento do consumidor, pelo simplismo do primeiro tipo de análise, que tem sido criticado por autores da área (Torres \& Allen, 2009). Ainda, a SEM pode ser vista, segundo Klem (1995), como extensão da regressão múltipla, se for considerado que na aplicação da regressão busca-se prever uma única variável-critério, enquanto na SEM há mais de uma variável dependente.

Uma das características básicas da SEM é que se pode testar uma teoria de ordem causal entre um conjunto de variáveis. Esta técnica oferece ao pesquisador a possibilidade de investigar quão bem as variáveis preditoras explicam a variável dependente e, ainda, qual das variáveis preditoras é a mais importante. Isto também pode ocorrer com o uso da regressão, embora deva ser lembrado que neste estudo pode-se ter mais de uma variável dependente em um único modelo (Maruyama, 1998). 
Assim, o modelo estrutural foi composto pelos tipos motivacionais presentes nas regressões stepwise, em cada um dos países, acrescidos da idade, que foi inserida com base na tabela de correlações praticada de modo exploratório. Por fim, foi cumprida a análise multigrupo que Marôco (2011) apresenta, que tem como objetivo avaliar se a estrutura do modelo estrutural é equivalente em diferentes grupos ou populações com características diferentes. O modelo estrutural encontrado no Brasil foi testado com a amostra estadunidense e o modelo encontrado para a amostra coletada nos Estados Unidos da América foi testada com a amostra brasileira.

\subsection{Modelo Geral de Pesquisa}

O modelo geral de pesquisa apresenta as relações entre Valores Humanos e Valores Pessoais com o tipo predominante de julgamento e a atribuição de significado no Brasil e Estados Unidos da América, considerando a avaliação do automóvel como objeto de consumo. A figura 16 apresenta o modelo geral de pesquisa com as suas respectivas hipóteses.

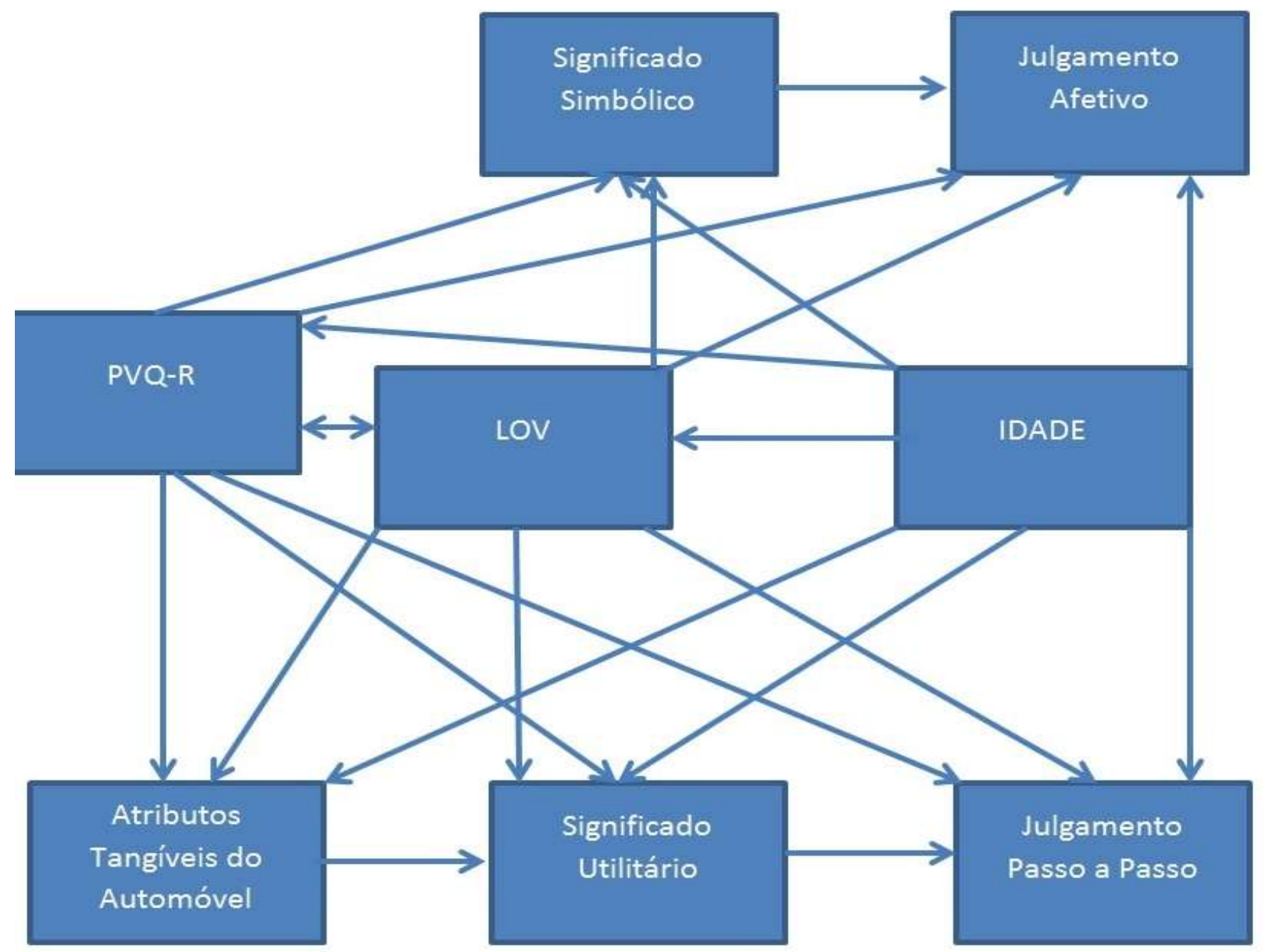

Figura 16. Modelo Geral de Pesquisa

Nota. Fonte: Própria 


\section{RESULTADOS}

Os resultados visam expor, mediante a análise estatística, os resultados encontrados por intermédio da coleta de dados. Inicialmente, serão apresentadas as variáveis por meio de estatística descritiva dos dados coletados. Em seguida, será apresentado tanto o Teste-t de média como as correlações, regressões e, por fim, o modelo estrutural derivado da análise confirmatória dos construtos utilizados na modelagem.

\subsection{Análise Descritiva}

Para satisfazer os requisitos usados para a análise multivariada de dados proposta por Tabachnick e Fidell (2001), Hair, Black, Babin, Anderson e Tathan (2009) e Field (2009), os dados foram examinados sem registros de discrepâncias na média e desvio-padrão. Os requisitos de normalidade das variáveis para os testes de média e regressões lineares foram conferidos. Considerando em particular as regressões lineares múltiplas e as recomendações de Miles e Shevlin (2001), linearidade, homocedasticidade e independência dos resíduos foram checadas. A tabela 19 apresenta, a seguir, as siglas utilizadas nas análises estatísticas e seu respectivo significado para cada construto estudado 
Tabela 19

Descrição das siglas dos construtos e variáveis utilizadas

\begin{tabular}{|c|c|c|}
\hline Construto/Variável & Sigla & Descriçãa \\
\hline \multirow{9}{*}{ Valores Pessoais } & LOV1 & Senso de pertencimento \\
\hline & LOV2 & Excitação \\
\hline & LOV3 & Relacionamentos afetivos com outros \\
\hline & LOV4 & Auto realização \\
\hline & LOV5 & Ser respeitado \\
\hline & LOV6 & Divertir-se e aproveitar a vida \\
\hline & LOV7 & Segurança \\
\hline & LOV8 & Auto respeito \\
\hline & LOV9 & Senso de sucesso \\
\hline \multirow{4}{*}{ Significado e Julgamento } & JA & Julgamento Afetivo \\
\hline & JPP & Julgamento Passo a Passo \\
\hline & SS & Significado Simbólico \\
\hline & SU & Significado Utilitário \\
\hline \multirow{19}{*}{ Valores Humanos } & SDT & Autodireção de Pensamento \\
\hline & SDA & Autodireção de Ação \\
\hline & ST & Estimulação \\
\hline & HE & Hedonismo \\
\hline & $\mathrm{AC}$ & Realização \\
\hline & POD & Poder de Domínio \\
\hline & POR & Poder sobre Recursos \\
\hline & FAC & Face \\
\hline & SES & Segurança Social \\
\hline & SEP & Segurança Pessoal \\
\hline & TR & Tradição \\
\hline & $\mathrm{COR}$ & Conformidade com Regras \\
\hline & COI & Conformidade Interpessoal \\
\hline & HUM & Humildade \\
\hline & BEC & Conformidade com Regras \\
\hline & BED & Benevolência Cuidado \\
\hline & UNC & Universalismo Compromisso \\
\hline & UNN & Universalismo Natureza \\
\hline & UNT & Universalismo Tolerância \\
\hline Atributos Tangíveis do Carro & Car_att & Atributos tangíveis do carro \\
\hline
\end{tabular}

Fonte: dados da pesquisa. (Valores Pessoais referem-se à escala LOV e Valores Humanos referem-se à escala PVQ-R)

Miles e Shevlin (2001) indicam que a multicolinearidade e a singularidade podem ser detectadas se o VIF (Variance Inflation Factor) ultrapassar 2,0 e a tolerância for próxima de zero. O maior valor de VIF entre as variáveis independentes das regressões lineares 
múltiplas foi 1,5 e o menor valor de tolerância encontrado foi 0,75 , indicando que esses requisitos não foram violados.

A tabela 20 expõe para todos os construtos estudados no Brasil e a tabela 21 demonstra os mesmos construtos coletados nos Estados Unidos da América. São apresentados suas médias, medianas, modas, desvio-padrão, variâncias, valores máximo e mínimo no intuito de apontar alguma discrepância nos dados, decorrente de erros de digitação, gerando dados extremos (outliers) ou dados incongruentes. Os dados extremos foram excluídos, segundo as sugestões de Marôco (2011) e Tabachnick e Fidell (2011), inicialmente por meio de análise univariada, utilizando o diagrama de caixa, também conhecido como diagrama de bigode. Para os dados extremos multivariados foi utilizada a distância de Mahalanobis como critério de exclusão, respeitando os graus de liberdade de cada uma das regressões que foram realizadas para atender o modelo de pesquisa. Após a exclusão de 23 casos extremos no Brasil e 15 casos extremos nos Estados Unidos da América restaram 562 observações no Brasil e 450 dados válidos nos Estados Unidos da América.

West, Finch e Curran (1995) apontam que a normalidade dos dados pode ser observada quando a curtose e a assimetria, dividos pelos seus respectivos erros, apresentam resultados entre -7 e 7 . Com relação às variáveis utilizadas no estudo, em nenhum dos países onde foi feita a coleta dos dados,, foram encontrados resultados que ultrapassassem esses valores que, portanto, denotam normalidade dos dados. Em todas as variáveis, o menor valor do indicador de curtose encontrado no Brasil foi de $-0,93$ e o maior 5,05. Na análise dos casos estudados para a amostra coletada nos Estados Unidos da América, o menor valor foi -0,92 e o maior 1,55. As tabelas 20 e 21 apresentam os índices de curtose e assimetria divididos pelos seus respectivos erros. 
Tabela 20

Estatística descritiva dos dados coletados no Brasil

\begin{tabular}{|c|c|c|c|c|c|c|c|c|c|c|}
\hline Construto & Variável & Média & Mediana & Moda & $\begin{array}{l}\text { Desvio } \\
\text { Padrão }\end{array}$ & Variância & Curtose & Assimetria & Min. & Máx. \\
\hline \multirow{9}{*}{$\begin{array}{l}\text { Valores } \\
\text { Pessoais }\end{array}$} & LOV1 & 7,26 & 8 & 9 & 2,02 & 4,1 & 0,82 & 3,76 & 1 & 10 \\
\hline & LOV2 & 6,96 & 7 & 9 & 2,02 & 4,12 & 1,04 & 3,21 & 1 & 10 \\
\hline & LOV3 & 7,85 & 9 & 9 & 1,83 & 3,36 & 5,12 & 3,44 & 1 & 10 \\
\hline & LOV4 & 8,84 & 9 & 9 & 1,34 & 1,8 & 5,43 & 4,55 & 1 & 10 \\
\hline & LOV5 & 7,6 & 8 & 9 & 1,85 & 3,42 & 3,06 & 3,71 & 1 & 10 \\
\hline & LOV6 & 8,83 & 9 & 9 & 1,27 & 1,61 & 3,4 & 4,01 & 1 & 10 \\
\hline & LOV7 & 8,01 & 9 & 9 & 1,47 & 2,16 & 4,08 & 3,87 & 1 & 10 \\
\hline & LOV8 & 8,26 & 9 & 9 & 1,36 & 1,85 & 3,83 & 4,23 & 1 & 10 \\
\hline & LOV9 & 8,41 & 9 & 9 & 1,14 & 1,3 & 5,05 & 5,21 & 1 & 10 \\
\hline \multirow{4}{*}{$\begin{array}{l}\text { Significado e } \\
\text { Julgamento }\end{array}$} & JA & 3,49 & 3,35 & 3 & 1,35 & 1,82 & 0,52 & $-0,89$ & 1 & 7 \\
\hline & JPP & 2,51 & 2,97 & 4 & 1,1 & 1,2 & 1,88 & $-2,3$ & 1 & 7 \\
\hline & SS & 3,6 & 3,67 & 3 & 1,42 & 1,42 & $-0,56$ & $-1,1$ & 1 & 7 \\
\hline & SU & 3,53 & 3,96 & 3 & 1,37 & 1,37 & 0,52 & 0,23 & 1 & 7 \\
\hline \multirow{19}{*}{$\begin{array}{l}\text { Valores } \\
\text { Humanos }\end{array}$} & SDT & 4,95 & 5 & 5 & 0,72 & 0,52 & 1,56 & 2,12 & 2 & 6 \\
\hline & SES & 4,75 & 5 & 5 & 0,93 & 0,86 & 0,79 & 2,02 & 1,33 & 6 \\
\hline & $\mathrm{HE}$ & 4,8 & 5 & 5 & 0,86 & 0,73 & $-0,93$ & 2,15 & 1,33 & 6 \\
\hline & $\mathrm{COI}$ & 4,42 & 4,67 & 5 & 1,01 & 1,04 & 0,48 & 1,89 & 1 & 6 \\
\hline & UNC & 4,91 & 5 & 5 & 0,85 & 0,73 & 1,12 & 2,56 & 1,33 & 6 \\
\hline & POD & 3,34 & 3,33 & 3 & 1,28 & 1,64 & 0,5 & 1,89 & 1 & 6 \\
\hline & HUM & 4,57 & 4,66 & 4 & 0,88 & 0,78 & 0,06 & 1,34 & 1,33 & 6 \\
\hline & UNN & 4,24 & 4.33 & 5 & 1,15 & 1,32 & $-0,48$ & 1,23 & 1 & 6 \\
\hline & FAC & 4,59 & 4,67 & 5 & 1,01 & 1,02 & 0,49 & 1,78 & 1 & 6 \\
\hline & BEC & 5,28 & 5,33 & 6 & 0,69 & 0,48 & 4,1 & 2,17 & 1,67 & 6 \\
\hline & $\mathrm{ST}$ & 4,25 & 4,33 & 5 & 1,07 & 1,15 & $-0,35$ & 1,78 & 1 & 6 \\
\hline & POR & 3,15 & 3 & 3 & 1,3 & 1,65 & $-0,84$ & 1,01 & 1 & 6 \\
\hline & SEP & 4,73 & 5 & 5 & 0,8 & 0,64 & 0,83 & 2,13 & 1,67 & 6 \\
\hline & UNT & 4,7 & 5 & 5 & 0,92 & 0,85 & 0,13 & 1,89 & 1,67 & 6 \\
\hline & COR & 4,46 & 4,67 & 5 & 1,07 & 1,16 & 0,57 & 0,89 & 1 & 6 \\
\hline & SDA & 4,92 & 5 & 5 & 0,82 & 0,68 & 1,5 & 1,76 & 1,67 & 6 \\
\hline & $\mathrm{AC}$ & 4,51 & 4,67 & 5 & 0,98 & 0,97 & 0,09 & 1,56 & 1,67 & 6 \\
\hline & $\mathrm{TR}$ & 4,21 & 4,33 & 5 & 1,11 & 1,23 & 0,45 & 1,74 & 1 & 6 \\
\hline & BED & 5,12 & 5,33 & 6 & 0,8 & 0,64 & 3,16 & 4,24 & 1 & 6 \\
\hline $\begin{array}{l}\text { Atributos } \\
\text { tangíveis do } \\
\text { carro }\end{array}$ & Car_att & 7,5 & 8 & 9 & 1,35 & 1,28 & 1,12 & 1.65 & 2 & 10 \\
\hline
\end{tabular}

Fonte: dados da pesquisa. 
As variáveis foram transformadas conforme as recomendações de Schwartz et al. (2012), que aponta que para praticar análises estatísticas multivariadas com Valores Humanos é necessário realizar a correção para aquiescência, procedimento no qual subtrai-se a média do indivíduo na escalada dos itens daquela mesma escala. Em função de as escalas originais possuírem valores máximos diferentes, optou-se por manter os valores máximos originais e transformar os resultados em afastamento padrão (escore-z); assim, todas as escaladas foram submetidas à correção para aquiescência e transformadas em afastamento padrão.

Analisando as variáveis estudadas para a amostra brasileira e considerando Valores Pessoais, foram encontradas as maiores médias para "Autorrealização" $(8,84)$ e "Divertir-se e Aproveitar a vida" $(8,83)$. Considerando os tipos de julgamento e atribuição de significado, o maior valor encontrado foi para "Significado Simbólico" (3,60). Os Valores Humanos apresentaram maiores médias para "Autodireção de pensamento" (4,95), "Universalismo Compromisso" (4,91), "Autodireção de Ação" $(4,92)$ e o Valor Humano com maior média foi "Benevolência Dependência" (5,12). A tabela 21 apresenta a estatística descritiva para os dados coletados nos Estados Unidos da América. 
Tabela 21

Estatística descritiva dos dados coletados nos Estados Unidos da América

\begin{tabular}{|c|c|c|c|c|c|c|c|c|c|c|}
\hline Construto & Variável & Média & Mediana & Moda & $\begin{array}{c}\text { Desvio } \\
\text { Padrão } \\
\end{array}$ & Variância & Curtose & $\begin{array}{c}\text { Assime- } \\
\text { tria }\end{array}$ & Min & Máx \\
\hline \multirow{9}{*}{$\begin{array}{l}\text { Valores } \\
\text { Pessoais }\end{array}$} & LOV1 & 6,22 & 7 & 10 & 2,89 & 8,3 & $-0,79$ & 1,08 & 1 & 10 \\
\hline & LOV2 & 5,12 & 5 & 6 & 2,72 & 7,4 & 0,72 & 0,37 & 1 & 10 \\
\hline & LOV3 & 6,93 & 8 & 9 & 2,98 & 8,88 & $-0,21$ & 0,66 & 1 & 10 \\
\hline & LOV4 & 7,44 & 8 & 10 & 2,74 & 7,53 & 1,27 & 1,49 & 1 & 10 \\
\hline & LOV5 & 5,2 & 5 & 5 & 2,81 & 7,94 & $-0,82$ & 0,94 & 1 & 10 \\
\hline & LOV6 & 7,01 & 8 & 8 & 2,84 & 8,07 & 0,5 & 3,93 & 1 & 10 \\
\hline & LOV7 & 7,3 & 8 & 10 & 2,98 & 8,89 & 0,91 & 2,26 & 1 & 10 \\
\hline & LOV8 & 7,46 & 8 & 10 & 2,83 & 8,02 & 1,55 & 3,23 & 1 & 10 \\
\hline & LOV9 & 6,94 & 8 & 10 & 2,85 & 8,13 & 0,21 & 2,89 & 1 & 10 \\
\hline \multirow{4}{*}{$\begin{array}{c}\text { Significado } \\
\text { e } \\
\text { Julgamento }\end{array}$} & JA & 3,1 & 2,55 & 4 & 0,99 & 3,6 & $-0,32$ & 0,34 & 1 & 10 \\
\hline & JPP & 4,13 & 3,21 & 4 & 0,8 & 1,67 & 1,01 & 1,23 & 1,17 & 7 \\
\hline & SS & 2,95 & 2,4 & 4 & 2,2 & 4,87 & 0,2 & $-0,89$ & 2,17 & 7 \\
\hline & SU & 5,92 & 6 & 4 & 1,61 & 2,6 & 0,61 & 3,19 & 1,14 & 7 \\
\hline \multirow{19}{*}{$\begin{array}{l}\text { Valores } \\
\text { Humanos }\end{array}$} & SDT & 4,97 & 4,97 & 5 & 0,77 & 0,59 & 1,07 & 2,67 & 0,33 & 7 \\
\hline & SES & 4,28 & 4,33 & 4 & 1,04 & 1,09 & $-0,32$ & 2,01 & 2 & 6 \\
\hline & $\mathrm{HE}$ & 3,52 & 4,33 & 4 & 1,02 & 1,05 & $-0,21$ & 1,03 & 1,33 & 6 \\
\hline & $\mathrm{COI}$ & 3,89 & 4 & 4 & 1,16 & 1,35 & $-0,61$ & 1,38 & 1 & 6 \\
\hline & $\mathrm{UNC}$ & 4,68 & 5 & 5 & 1,02 & 1,03 & 0,43 & 2,54 & 1 & 6 \\
\hline & POD & 2,69 & 2,66 & 2 & 1,12 & 1,27 & 0,29 & $-0,45$ & 1,33 & 6 \\
\hline & HUM & 4,32 & 4,33 & 5 & 0,93 & 0,86 & $-0,34$ & 3,56 & 1 & 6 \\
\hline & UNN & 4,03 & 4 & 4 & 1,19 & 1,42 & $-0,49$ & 1,45 & 2 & 6 \\
\hline & FAC & 3,76 & 3,66 & 3 & 1,14 & 1,29 & $-0,51$ & 1,12 & 1 & 6 \\
\hline & BEC & 4,93 & 5 & 5 & 0,86 & 0,74 & $-0,92$ & 2,08 & 1 & 6 \\
\hline & ST & 3,72 & 3,66 & 3 & 1,15 & 1,32 & 1,2 & 0,94 & 1,33 & 6 \\
\hline & POR & 2,63 & 2,33 & 2 & 1,23 & 1,51 & $-0,43$ & $-0,67$ & 1 & 6 \\
\hline & SEP & 4,6 & 4,67 & 4 & 0,88 & 0,78 & 0,35 & 2,13 & 1 & 6 \\
\hline & UNT & 4,75 & 5 & 5 & 0,98 & 0,96 & 1,42 & 2,12 & 1 & 6 \\
\hline & COR & 3,97 & 4,33 & 5 & 1,35 & 1,82 & $-0,7$ & 1,39 & 1 & 6 \\
\hline & SDA & 3,93 & 5 & 5 & 0,77 & 0,6 & 0,4 & 1,27 & 1 & 6 \\
\hline & $\mathrm{AC}$ & 3,82 & 4 & 4 & 1,01 & 1,03 & $-0,52$ & 1,11 & 2 & 6 \\
\hline & $\mathrm{TR}$ & 3,14 & 3 & 3 & 1,35 & 1,83 & $-0,92$ & 0,45 & 1 & 6 \\
\hline & BED & 4,8 & 5 & 5 & 0,83 & 0,69 & 0,91 & 2,41 & 1 & 6 \\
\hline $\begin{array}{l}\text { Atributos } \\
\text { tangíveis do } \\
\text { Carro }\end{array}$ & Car_att & 8,7 & 8 & 9 & 1,1 & 1,21 & 1,52 & $-0,98$ & 3,75 & 10 \\
\hline
\end{tabular}

Fonte: Dados da pesquisa. 


\subsection{Teste de médias}

No intuito de verificar qual tipo de julgamento prevalece em cada país, foram seguidas as recomendações de Hair, Black, Babin, Anderson e Tathan (2009) que indicam que o teste de igualdade de médias para comparação de dois grupos mais adequado é o testet. O teste confrontou as diferenças de médias entre estadunidenses e brasileiros acerca do tipo de julgamento mais predominante na compra de um automóvel (afetivo ou passo a passo).

O resultado apresentou diferença significativa para variâncias iguais assumidas, indicando que no Brasil o julgamento afetivo é predominante e sua média é maior do que o julgamento afetivo nos Estados Unidos da América para a compra de automóvel. No caso do julgamento passo a passo, o resultado apontou média superior significativa em relação à média do Brasil para julgamento passo a passo, indicando que brasileiros são predominantemente afetivos na compra de automóvel e estadunidenses predominantemente racionais. Os resultados podem ser observados na tabela 22.

Tabela 22

Testes-T para os tipos de julgamento comparando Brasil e Estados Unidos da América

\begin{tabular}{|c|c|c|c|c|c|c|c|}
\hline Tipo de Julgamento & País & $\mathrm{N}$ & Média & $\begin{array}{l}\text { Desvio- } \\
\text { padrão }\end{array}$ & GL & $\mathrm{t}$ & Sig. \\
\hline \multirow{2}{*}{ Julgamento Afetivo } & Brasil & 542 & 3.49 & 0.94 & \multirow{2}{*}{990} & \multirow{2}{*}{4.91} & \multirow{2}{*}{0.00} \\
\hline & EUA & 450 & 3.10 & 0.99 & & & \\
\hline \multirow{2}{*}{ Julgamento passo a passo } & Brasil & 562 & 2.51 & 1.03 & \multirow{2}{*}{1010} & \multirow{2}{*}{25.3} & \multirow{2}{*}{0.00} \\
\hline & EUA & 450 & 4.13 & 0.98 & & & \\
\hline
\end{tabular}

Fonte: Dados da pesquisa

\subsection{Correlações}

Para verificar a correlação entre idade, valores pessoais e julgamento e significado, no Brasil, foi realizado o $r$ de Pearson, como indicam de Hair, Black, Babin, Anderson e Tathan (2009). A Tabela 23 mostra a correlação entre as variáveis, que indicam que idade não se correlaciona com valores pessoais e também não se correlaciona com nenhum tipo de julgamento ou atribuição de significado. A tabela 24 demonstra a correlação entre as variáveis idade, valores pessoais, atributos tangíveis do carro, julgamento e significado nos Estados Unidos da América.

Observa-se pequena correlação entre os valores pessoais e os tipos de julgamento e significado no Brasil, sendo a maior correlação entre LOV7 e julgamento afetivo $(0,17)$. As correlações entre LOV1 e LOV5 (0,51), LOV3 e LOV4 (0,62), LOV4 e LOV5 (0,53), LOV4 e LOV6 (0,55), LOV4 e LOV8 (0,63), LOV4 e LOV9 (0,63), LOV6 e LOV8 (0,55), LOV6 e 
LOV9 (0,53), LOV7 e LOV8 (0,52) e LOV8 e LOV9 $(0,64)$ apresentam coeficiente de correlação acima de 0,50 , sugerindo que existe forte relação entre os fatores (Tabachnick \& Fidell, 2001). Para os atributos tangíveis do carro, as correlações significativas encontadas foram de 0,14 para LOV2, 0,11 para LOV5 e LOV6, 0,27 para LOV7 e 0,16 para LOV8.

Considerando os tipos de julgamento e a atribuição de significado, os atributos tangíveis do carro correlacionam-se mais fortemente com JPP $(0,32)$. As demais correlações foram de 0,20 para significado simbólico, para significado utilitário 0,25 e julgamento afetivo 0,23. Atributos tangíveis do carro não apresentaram correlação com idade.

Observa-se pequena correlação entre os valores pessoais e os tipos de julgamento e significado, nos Estados Unidos da América, e a maior correlação entre valores pessoais e tipos de julgamento encontrada corresponde a LOV9 e Significado Utilitário (0,38). As correlações entre LOV1 e LOV3 (0,74), LOV1 e LOV7 (0,52), LOV2 e LOV6 (0,56), LOV3 e LOV4 (0,58), LOV3 e LOV6 (0,52), LOV3 e LOV7 (0,60), LOV3 e LOV8 (0,60), LOV3 e LOV9 (0,55), LOV4 e LOV6 (0,61), LOV4 e LOV7 (0,65), LOV4 e LOV9 (0,78), LOV6 e LOV7 (0,69), LOV6 e LOV9 (0,57), LOV7 e LOV8 (0,69), LOV7 e LOV9 $(0,57)$, LOV8 e LOV9 $(0,80)$ apresentam coeficiente de correlação acima de 0,50 sugerindo que existe forte relação entre os fatores (Tabachnick \& Fidell, 2001).

Considerando os atributos tangíveis do carro, as correlações com Valores Pessoais foram de 0,20 com LOV1, LOV2 (0,14), LOV5 e LOV6 $(0,11)$ ambos, LOV7 $(0,27)$ e LOV8 $(0,16)$. Em consideração aos tipos de julgamento e atribuição de significado, a maior correlação foi com julgamento passo a passo $(0,48)$, significado simbólico $(0,15)$ e significado utilitário $(0,14)$. A variável Atributos tangíveis do carro apresentou correlação de 0,13 com idade nos Estados Unidos da América. 
Tabela 23

Correlações entre valores pessoais, idade, atributos tangíveis do carro, significado e julgamento no Brasil

\begin{tabular}{|c|c|c|c|c|c|c|c|c|c|c|c|c|c|c|c|}
\hline & Lov1 & Lov2 & Lov3 & Lov4 & Lov5 & Lov6 & Lov7 & Lov8 & Lov9 & SS & JPP & SU & JA & Idade & \\
\hline Lov1 & 1 & & & & & & & & & & & & & & \\
\hline Lov2 & $0,44^{* *}$ & 1 & & & & & & & & & & & & & \\
\hline Lov3 & $0,43^{* *}$ & $0,46^{* *}$ & 1 & & & & & & & & & & & & \\
\hline Lov4 & $0,42^{* *}$ & $0,37^{* *}$ & $0,62^{* *}$ & 1 & & & & & & & & & & & \\
\hline Lov5 & $0,51^{* *}$ & $0,41^{* *}$ & $0,49^{* * *}$ & $0,53^{* *}$ & 1 & & & & & & & & & & \\
\hline Lov6 & $0,30^{* *}$ & $0,40^{* *}$ & $0,38^{* * *}$ & $0,55^{* *}$ & $0,40^{* * *}$ & 1 & & & & & & & & & \\
\hline Lov7 & $0,24^{* *}$ & $0,18^{* *}$ & $0,27^{* *}$ & $0,42^{* *}$ & $0,28^{* * *}$ & $0,44^{* * *}$ & 1 & & & & & & & & \\
\hline Lov8 & $0,28^{* *}$ & $0,33^{* *}$ & $0,46^{* *}$ & $0,63^{* *}$ & $0,45^{* *}$ & $0,55^{* *}$ & $0,52^{* *}$ & 1 & & & & & & & \\
\hline Lov9 & $0,37^{* *}$ & $0,38^{* *}$ & $0,44^{* *}$ & $0,63^{* *}$ & $0,46^{* * *}$ & $0,53^{* *}$ & $0,43^{* *}$ & $0,64^{* *}$ & 1 & & & & & & \\
\hline SS & $0,11^{*}$ & $0,23^{* *}$ & 0,09 & 0 & $0,17^{* *}$ & $-0,01$ & 0,06 & 0,06 & 0,03 & 1 & & & & & \\
\hline JPP & 0,05 & 0,02 & 0,09 & $-0,01$ & 0,03 & $-0,03$ & $0,11^{*}$ & 0,1 & 0,01 & 0,05 & 1 & & & & \\
\hline SU & 0,08 & $0,12^{*}$ & 0,04 & -0.03 & 0,05 & $-0,05$ & 0,06 & 0 & 0,02 & $0,25^{* *}$ & $0,33^{* *}$ & 1 & & & \\
\hline JA & 0,04 & $0,12^{*}$ & $0,10^{*}$ & 0,08 & 0,08 & 0,03 & $0,17^{* *}$ & $0,13^{*}$ & $0,11^{*}$ & $0,45^{\text {** }}$ & $0,26^{* *}$ & $0,27^{\text {*** }}$ & 1 & & \\
\hline Idade & 0,04 & $-0,01$ & 0 & $-0,03$ & 0,01 & $-0,03$ & 0,01 & $-0,03$ & 0,03 & $-0,02$ & $-0,02$ & $-0,02$ & $-0,06$ & 1 & \\
\hline \multicolumn{2}{|c|}{ Car_att } & 0,08 & $0,14^{*}$ & 0,05 & 0,1 & $0,11^{*}$ & $0,11^{*}$ & $0,27^{*}$ & $0,16^{*}$ & 0,08 & $0,20^{*}$ & $0,32^{*}$ & $0,25^{*}$ & $0,23^{*}$ & 0,01 \\
\hline
\end{tabular}

Fonte: Dados da Pesquisa (NOTA:** representam valores para $\mathrm{p}>0,01$ e ${ }^{*}$ representam valores para $p>0,05$ ) 
Tabela 24

Correlações entre valores pessoais, idade, atributos tangíveis do carro, significado e julgamento nos Estados Unidos da América

\begin{tabular}{|c|c|c|c|c|c|c|c|c|c|c|c|c|c|c|}
\hline & Lov1 & Lov2 & Lov3 & Lov4 & Lov5 & Lov6 & Lov7 & Lov8 & Lov9 & SS & JPP & SU & JA & Idade \\
\hline Lov1 & 1 & & & & & & & & & & & & & \\
\hline Lov2 & $0,29^{*}$ & 1 & & & & & & & & & & & & \\
\hline Lov3 & $0,74^{*}$ & $0,37^{*}$ & 1 & & & & & & & & & & & \\
\hline Lov4 & $0,45^{* *}$ & $0,31^{* *}$ & $0,58^{* * *}$ & 1 & & & & & & & & & & \\
\hline Lov5 & $0,49^{* *}$ & $0,35^{* *}$ & $0,45^{* *}$ & $0,43^{* *}$ & 1 & & & & & & & & & \\
\hline Lov6 & $0,45^{* *}$ & $0,56^{* *}$ & $0,52^{* * *}$ & $0,61^{* *}$ & $0,35^{* *}$ & 1 & & & & & & & & \\
\hline Lov7 & $0,52^{* *}$ & $0,24^{* *}$ & $0,60^{* *}$ & $0,65^{* *}$ & $0,41^{* *}$ & $0,61^{* *}$ & 1 & & & & & & & \\
\hline Lov8 & $0,49^{* * *}$ & $0,28^{* *}$ & $0,60^{* *}$ & $0,82^{\text {** }}$ & $0,49^{* *}$ & $0,60^{* *}$ & $0,69^{* *}$ & 1 & & & & & & \\
\hline Lov9 & $0,47^{* *}$ & $0,30^{* *}$ & $0,55^{* *}$ & $0,78^{* *}$ & $0,57^{* *}$ & $0,57^{* *}$ & $0,65^{* *}$ & $0,80^{* *}$ & 1 & & & & & \\
\hline $\mathrm{SS}$ & 0,06 & $0,20^{* *}$ & 0,04 & $-0,01$ & $0,22^{* *}$ & 0 & $-0,1$ & $0, \overline{-}^{*}$ & 0,02 & 1 & & & & \\
\hline JPP & 0,11 & $-0,04$ & $0,13^{* *}$ & $0,13^{*}$ & $-0,01$ & 0,07 & $0,19^{* *}$ & 0,05 & 0,07 & $0,10^{* * *}$ & 1 & & & \\
\hline SU & $0,12^{*}$ & $0,25^{* *}$ & $0,16^{* *}$ & 0,04 & $0,25^{* *}$ & 0 & 0,19 & $-0,04$ & $0,38^{* *}$ & $0,30^{* *}$ & $0,43^{* *}$ & 1 & & \\
\hline $\mathrm{JA}$ & $0,25^{*}$ & $0,25^{*}$ & $0,19^{* * *}$ & 0,08 & $0,25^{* *}$ & $010^{*}$ & $0,17^{* *}$ & 0,09 & $0,12^{* *}$ & $0,65^{* *}$ & 0,08 & $0,20^{* *}$ & 1 & \\
\hline Idade & 0,2 & $0,20^{-}$ & 0,05 & $0,16^{* *}$ & $-0,02$ & $0,15^{* *}$ & 0,01 & $0,15^{*}$ & 0,1 & $-0,14^{*}$ & $-0,13$ & $\overline{-}^{-} 24^{* *}$ & $-0,14^{*}$ & 1 \\
\hline Car_att & $0,20^{*}$ & 0 & $0,18^{*}$ & $0,14^{*}$ & 0,06 & $0,12^{*}$ & $0,25^{*}$ & 0,07 & 0,09 & $0, \overline{5}^{*}$ & $0,48^{*}$ & $0,14^{*}$ & 0,07 & $0,13^{*}$ \\
\hline
\end{tabular}

Fonte: Dados da Pesquisa (NOTA:** representam valores para $\mathrm{p}>0,01$ e ${ }^{*}$ representam valores para $\mathrm{p}>0,05)$

Utilizando Valores Humanos em substituição aos Valores Pessoais, a correlação com idade e os tipos de julgamento e significado no Brasil observa-se que idade não apresentou correlação com nenhum Valor Humano, tipo de julgamento ou atribuição de significado. "Julgamento Afetivo" apresentou a correlação com "Autodireção de Ação" $(0,28)$, "Autodireção de Pensamento" (0,15), "Hedonismo" (0,30), "Conformidade Interpessoal" $(0,17)$, "Poder de Domínio" $(0,34)$, , Universalismo Natureza" $(0,19)$.

A variável "Julgamento Passo a Passo" apresentou a maior correlação com "Universalismo Tolerância" $(0,29)$." Significado Simbólico" apresentou a maior correlação com "Poder Sobre Recursos" $(0,60)$ e correlações de 0,39 com "Poder de Domínio", 0,37 com 
"Realização", 0,24 com "Estimulação", 0,19 com "Face", 0,27 com "Hedonismo". Entre os Valores Humanos, nenhum Valor Humano correlacionou-se acima de 0,50 com outro Valor Humano, sugerindo a existência de forte comunalidade; portanto, apontando um fator de segunda ordem. Os resultados encontrados nas correlações entre idade, Valores Humanos e Tipos de Julgamento e Significado no Brasil encontram-se na tabela 25.

Já a variável "Significado Utilitário" demonstrou a maior correlação com "Estimulação" (0,20) e correlações de 0,14 com "Segurança Pessoal", 0,17 com "Conformidade Interpessoal, 0,18 com "Poder de Domínio", 0,13 com "Face”e 0,15 com "Universalismo Natureza".

Com relação às observações realizadas nos Estados Unidos da América, a idade apresentou correlação com "Significado Simbólico" (0,43), "Julgamento Afetivo" (0,38). Acerca dos Valores Humanos, "idade" demonstrou a maior correlação com "Poder de Recursos" $(0,24)$, “Autodireção de Ação" $(0,20)$, "Hedonismo" $(0,23)$, "Realização" $(-0,20)$ e "Estimulação" (0,23).

Observa-se a maior correlação entre os "Julgamento Afetivo" e Valores Humanos com "Realização" $(0,42)$ e correlações de 0,15 para "Autodireção de Pensamento", 0,27 para “Autodireção de Ação", 0,31 para "Hedonismo", 0,17 para "Conformidade Interpessoal", 0,34 para "Poder de Domínio", 0,19 para "Universalismo Natureza", 0,37 para "Face”, 0,12 para "Benevolência Cuidado", 0,25 para "Estimulação", 0,38 para "Poder de Recursos", 0,16 com "Segurança Pessoal”, 0,12 com “Conformidade com Regras”, 0,11 com "Autodireção de Ação", 0,25 com "Tradição", 0,23 com "Benevolência Dependência". "Julgamento Passo a Passo" obteve a maior correlação com "Benevolência de Dependência” $(0,29)$.

"Significado Simbólico" correlacionou-se com "Poder de Dominação" como sua maior correlação, representada por 0,56 seguido por "Realização" em 0,49, "Poder sobre Recursos" (0,46), "Face” (0,40), "Estimulação" $(0,32)$ e "Hedonismo" (0,27). "Significado Utilitário" correlacionou-se em maior grau com "Hedonismo" $(0,35)$, seguido por "Poder sobre Recursos" $(0,34)$ e "Poder de Dominação" $(0,33)$.

Nenhum dos Valores Humanos apresentou correlação entre eles próprios superiores a 0,50.Os resultados encontrados nas correlações entre idade, Valores Humanos e Tipos de Julgamento e Significado para a amostra coletada nos Estados Unidos da América se encontram na tabela 26. 
Tabela 25

Correlações entre Valores Humanos, Significado e Julgamento e Idade no Brasil

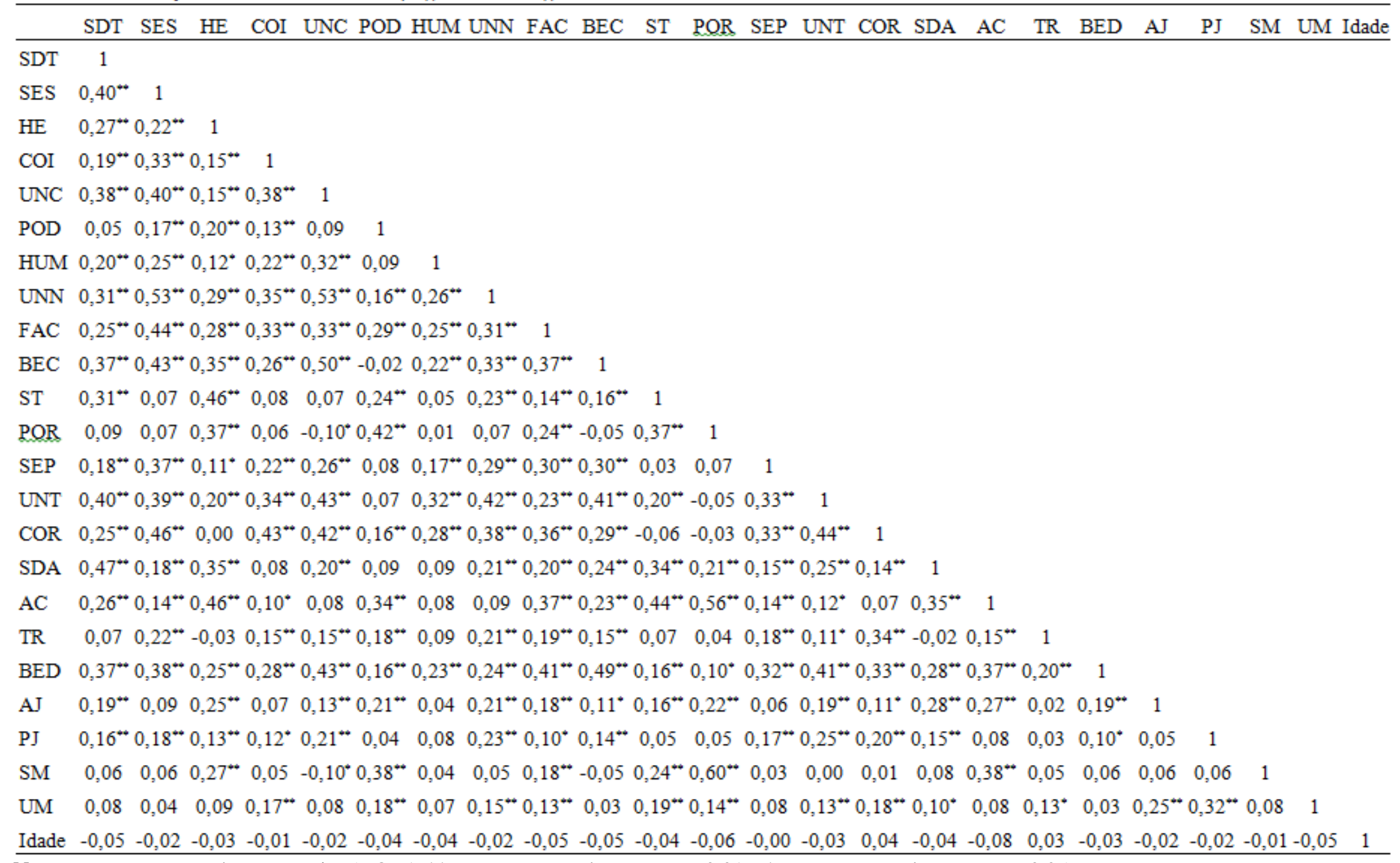

Nota. Fonte: Fonte:Dados a Pesquisa (NOTA:** representam valores para $p>0,01$ e *representam valores para $\mathrm{P}>0,05$ 
Tabela 26

Correlações entre Valores Humanos, Significado e Julgamento e Idade nos Estados Unidos da América

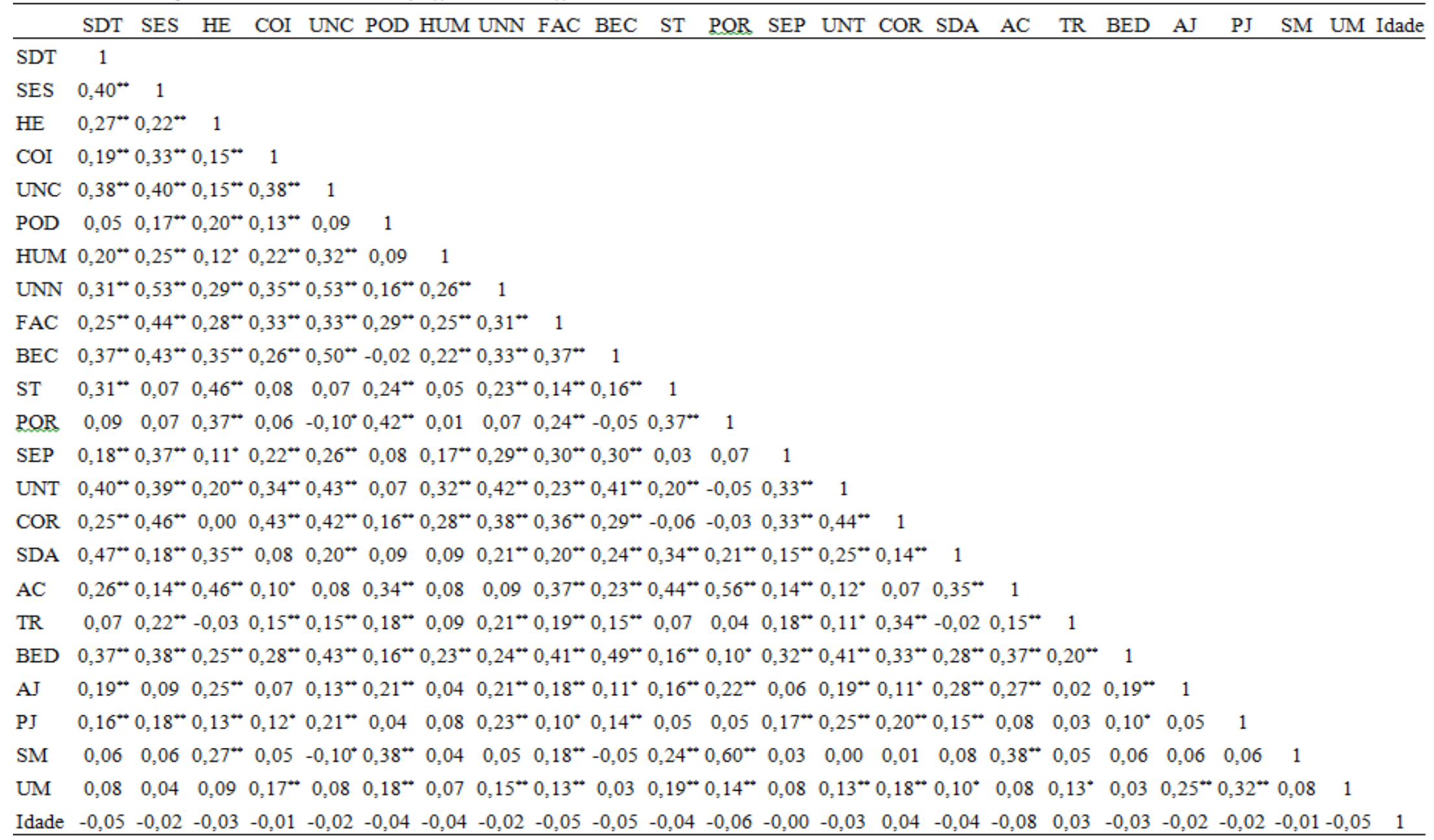

Fonte:Dados da Pesquisa (NOTA:** representam valores para $\mathrm{p}>0,01 \mathrm{e} *$ representam valores para $\mathrm{P}>0,05$ ) 


\subsection{Regressões}

Com o objetivo de testar a capacidade de predizer os tipos de julgamento, a atribuição de significado e os atributos tangíveis do carro, foram realizadas regressões lineares múltiplas, que utilizam os Valores Pessoais e Valores Humanos, conjuntamente e separadamente considerando ambos os países do estudo (Brasil e Estados Unidos da América). Foram realizadas regressões lineares múltiplas também para testar se os Valores Pessoais e Valores Humanos eram capazes de predizer a variável atributos tangíveis do carro.

Os coeficientes de determinação $\left(\mathrm{R}^{2}\right)$, ou seja a proporção da variablidade total que é explicada pela regressão, de maneira geral, tende a aumentar quando variáveis independentes são incluídas no modelo (Marôco, 2011). Dessa maneira Healy (1984) sugere que, quando são comparados modelos com quantidades de variáveis dependentes, o $R^{2}$ não é o mais indicado e sim o $\mathrm{R}^{2}$ ajustado. $\mathrm{O} \mathrm{R}^{2}$ ajustado pode ser utilizado como melhor estimador do modelo por levar em consideração o aumento do $\mathrm{R}^{2}$ somente se a nova variável adicionada gerar um aumento no ajustamento do modelo, isto é, somente se variância dos erros diminuir relativamente à variância total explicada (Marôco, 2011).

Como os modelos testados possuem números de variáveis independentes diferentes (9 VIs utilizando os Valores Pessoais, 19 Vis utilizando os Valores Humanos e 25 VIs variáveis independentes utilizadas com ambos somados), decidiu-se utilizar as recomendações de Marôco (2011) e analisar as comparações entre eles observando o $\mathrm{R}^{2}$ ajustado.Assim, para Julgamento Afetivo, valores pessoais o $\mathrm{R}^{2}$ ajustado foi de 0,03 para Valores Pessoais, 0,14 para Valores Humanos e 0,14 para Valores Pessoais em conjunto com Valores Humanos, indicando nenhuma incrementação do modelo. Para o julgamento Passo a Passo, o $\mathrm{R}^{2}$ ajustado encontrado foi de 0,02 para Valores Pessoais, 0,08 para Valores Humanos e 0,08 também para ambos, em conjunto, indicando novamente nenhuma incrementação do modelo.

Considerando o Significado Simbólico como variável dependente, os Valores Pessoais apresentaram como variáveis independentes um $\mathrm{R}^{2}$ ajustado de 0,07 . Os Valores Humanos como variáveis independentes resultaram em $u m R^{2}$ ajustado de 0,37 e ambos em conjunto também 0,37. Para Significado Utilitário Valores Pessoais resultou em um $\mathbf{R}^{2}$ ajustado de 0,02 , enquanto Valores Humanos e ambos em conjunto resultaram em um $\mathrm{R}^{2}$ ajustado de 0,08 .

Finalmente, a variável dependente Atributos tangíveis do carro quando predita por Valores Pessoais resultou em $\mathrm{R}^{2}$ ajustado de 0,07. Considerando os Valores Humanos somente, e ambos em conjunto, o resultado foi igual, de um $\mathrm{R}^{2}$ ajustado de 0,12 . Tal 
resultado indica nenhuma incrementação com o aumento de variáveis no modelo. A tabela 27 apresenta todas as regressões realizadas no Brasil, todos os Valores (Humanos, Pessoais e ambos em conjunto) foram inseridos simultaneamente predizendo a variáveis dependentes.

Tabela 27

Regressões que utilizam Valores Pessoais e Valores Humanos no Brasil

\begin{tabular}{|c|c|c|c|c|c|c|}
\hline Variável Dependente & $\begin{array}{c}\text { Variáveis } \\
\text { Independentes }\end{array}$ & $\mathbf{R}$ & $\mathbf{R}^{2}$ & $\begin{array}{c}\mathbf{R}^{2} \\
\text { Ajustado }\end{array}$ & Sig. & $\begin{array}{c}\text { Teste } \\
\text { Estatístico }\end{array}$ \\
\hline Julgamento Afetivo & Valores Pessoais & 0,23 & 0,05 & 0,03 & 0,01 & $\mathrm{~F}=2,28$ \\
\hline Julgamento Afetivo & Valores Humanos & 0,43 & 0,18 & 0,14 & 0 & $\mathrm{~F}=4,22$ \\
\hline Julgamento Afetivo & $\begin{array}{l}\text { Valores Humanos + } \\
\text { Valores Pessoais }\end{array}$ & 0,44 & 0,19 & 0,14 & 0 & $\mathrm{~F}=3,31$ \\
\hline Julgamento Passo a Passo & Valores Pessoais & 0,2 & 0,04 & 0,02 & 0,09 & $\mathrm{~F}=1,68$ \\
\hline Julgamento Passo a Passo & Valores Humanos & 0,36 & 0,13 & 0,08 & 0 & $\mathrm{~F}=2,82$ \\
\hline Julgamento Passo a Passo & $\begin{array}{l}\text { Valores Humanos e } \\
\text { Pessoais }\end{array}$ & 0,37 & 0,13 & 0,08 & 0 & $\mathrm{~F}=2,39$ \\
\hline Significado Simbólico & Valores Pessoais & 0,31 & 0,09 & 0,07 & 0 & $\mathrm{~F}=4,22$ \\
\hline Significado Simbólico & Valores Humanos & 0,63 & 0,4 & 0,37 & 0 & $\mathrm{~F}=12,45$ \\
\hline Significado Simbólico & $\begin{array}{l}\text { Valores Humanos }+ \\
\text { Valores Pessoais }\end{array}$ & 0,63 & 0,4 & 0,37 & 0 & $\mathrm{~F}=8,85$ \\
\hline Significado Utilitário & Valores Pessoais & 0,21 & 0,04 & 0,02 & 0,07 & $\mathrm{~F}=1,81$ \\
\hline Significado Utilitário & Valores Humanos & 0,36 & 0,13 & 0,08 & 0 & $\mathrm{~F}=2,80$ \\
\hline Significado Utilitário & $\begin{array}{l}\text { Valores Humanos }+ \\
\text { Valores Pessoais }\end{array}$ & 0,36 & 0,13 & 0,08 & 0 & $\mathrm{~F}=2,18$ \\
\hline $\begin{array}{l}\text { Atributos tangíveis do } \\
\text { carro }\end{array}$ & Valores Pessoais & 0,31 & 0,1 & 0,07 & 0 & $\mathrm{~F}=4,37$ \\
\hline $\begin{array}{l}\begin{array}{l}\text { Atributos tangíveis do } \\
\text { carro }\end{array} \\
\end{array}$ & Valores Humanos & 0,4 & 0,16 & 0,12 & 0 & $\mathrm{~F}=3,58$ \\
\hline $\begin{array}{l}\text { Atributos tangíveis do } \\
\text { carro }\end{array}$ & $\begin{array}{l}\text { Valores Humanos }+ \\
\text { Valores Pessoais }\end{array}$ & 0,42 & 0,17 & 0,12 & 0 & $\mathrm{~F}=3,06$ \\
\hline
\end{tabular}

Fonte: Dados da Pesquisa

Para os sujeitos estudados nos Estados Unidos da América foram realizados os mesmos procedimentos, isto é, os tipos de julgamento, atribuição de significado e atributos tangíveis do carro. Considerando o Julgamento afetivo, o $\mathrm{R}^{2}$ ajustado para Valores Pessoais foi de 0,12 , enquanto para Valores Humanos e ambos em conjunto o $\mathrm{R}^{2}$ ajustado foi de 0,24 , indicando nenhuma incrementação do modelo. O julgamento Passo a Passo quando determinado por Valores Pessoais resultou em $\mathrm{R}^{2}$ ajustado de 0,06 , enquanto Valores Humanos e ambos somados resultou em $\mathrm{R}^{2}$ ajustado de 0,17 .

Considerando o Significado Simbólico como variável dependente e os Valores Pessoais como variáveis independentes, o $\mathrm{R}^{2}$ ajustado foi de 0,14 , enquanto Valores 
Humanos e o modelo conjunto obtiveram um $\mathrm{R}^{2}$ ajustado equivalente de 0,52. Para Significado Utilitário, o $\mathrm{R}^{2}$ ajustado obtido por meio da explicação da variância que utilizou Valores Pessoais foi de 0,12, enquanto Valores Humanos e o modelo conjunto resultaram ambos em 0,21.

Finalmente, considerando os Atributos tangíveis do carro como variável dependente, os Valores Pessoais resultaram em um $\mathrm{R}^{2}$ ajustado de 0,07, enquanto Valores Humanos e o modelo de ambos em conjunto atingiram um $\mathrm{R}^{2}$ ajustado de 0,30 . Para nenhuma das variáveis dependentes utilizadas nos Estados Unidos da América os Valores Pessoais apresentaram incremento quando utilizados em conjunto com Valores Humanos. Os resultados podem ser observados na tabela 28 .

Em função da alta multicolinearidade entre as variávéis utilizadas na Lista de Valores Pessoais (LOV), acima de 0,50 entre os diversos Valores Pessoais (em casos extremos acima de 0,80), sua incapacidade de explicar a variância de todas as variáveis dependentes utilizadas no modelo de modo superior aos Valores Humanos e a falta de acréscimo no $\mathrm{R}^{2}$ ajustado quando utilizadas no modelo conjunto (Valores Humanos + Valores Pessoais) indica redundância das escalas (Abbad \& Torres, 2002); portanto o refinamento do modelo somente levará em consideração os Valores Humanos nas regressões passo a passo e no modelo estrutural em sequência. 
Tabela 28

Regressões utilizando Valores Pessoais e Valores Humanos nos Estados Unidos da América

\begin{tabular}{|c|c|c|c|c|c|c|}
\hline Variável Dependente & Variáveis Independentes & $\mathbf{R}$ & $\mathbf{R}^{2}$ & $\begin{array}{c}\mathbf{R}^{2} \\
\text { Ajustado }\end{array}$ & Sig. & $\begin{array}{c}\text { Teste } \\
\text { Estatístico }\end{array}$ \\
\hline Julgamento Afetivo & Valores Pessoais & 0,4 & 0,1 & 0,12 & 0 & $\mathrm{~F}=5,34$ \\
\hline Julgamento Afetivo & Valores Humanos & 0,5 & 0,3 & 0,24 & 0 & $\mathrm{~F}=6,04$ \\
\hline Julgamento Afetivo & $\begin{array}{l}\text { Valores Humanos }+ \text { Valores } \\
\text { Pessoais }\end{array}$ & 0,6 & 0,3 & 0,24 & 0 & $\mathrm{~F}=4,72$ \\
\hline $\begin{array}{lll}\text { Julgamento } & \text { Passo } & \text { a } \\
\text { Passo } & & \\
\end{array}$ & Valores Pessoais & 0,3 & 0,1 & 0,06 & 0 & $\mathrm{~F}=3,01$ \\
\hline $\begin{array}{lll}\text { Julgamento } & \text { Passo } & \text { a } \\
\text { Passo } & & \end{array}$ & Valores Humanos & 0,5 & 0,2 & 0,17 & 0 & $\mathrm{~F}=4,20$ \\
\hline $\begin{array}{lll}\text { Julgamento Passo a } \\
\text { Passo }\end{array}$ & Valores Humanos e Pessoais & 0,5 & 0,3 & 0,17 & 0 & $\mathrm{~F}=3,38$ \\
\hline Significado Simbólico & Valores Pessoais & 0,4 & 0,2 & 0,14 & 0 & $\mathrm{~F}=6,54$ \\
\hline Significado Simbólico & Valores Humanos & 0,7 & 0,6 & 0,52 & 0 & $\mathrm{~F}=17,95$ \\
\hline Significado Simbólico & $\begin{array}{l}\text { Valores Humanos }+ \text { Valores } \\
\text { Pessoais }\end{array}$ & 0,8 & 0,6 & 0,52 & 0 & $\mathrm{~F}=12,44$ \\
\hline Significado Utilitário & Valores Pessoais & 0,4 & 0,2 & 0,12 & 0 & $\mathrm{~F}=5,60$ \\
\hline Significado Utilitário & Valores Humanos & 0,5 & 0,3 & 0,21 & 0 & $\mathrm{~F}=5,25$ \\
\hline Significado Utilitário & $\begin{array}{l}\text { Valores Humanos }+ \text { Valores } \\
\text { Pessoais }\end{array}$ & 0,5 & 0,3 & 0,21 & 0 & $\mathrm{~F}=4,10$ \\
\hline $\begin{array}{l}\text { Atributos tangíveis do } \\
\text { carro }\end{array}$ & Valores Pessoais & 0,3 & 0,1 & 0,07 & 0 & $\mathrm{~F}=3,70$ \\
\hline $\begin{array}{l}\text { Atributos tangíveis do } \\
\text { carro }\end{array}$ & Valores Humanos & 0,6 & 0,3 & 0,3 & 0 & $\mathrm{~F}=7,62$ \\
\hline $\begin{array}{l}\text { Atributos tangíveis do } \\
\text { carro }\end{array}$ & $\begin{array}{l}\text { Valores Humanos }+ \text { Valores } \\
\text { Pessoais }\end{array}$ & 0,6 & 0,4 & 0,3 & 0 & $\mathrm{~F}=5,78$ \\
\hline
\end{tabular}

Fonte: Dados da Pesquisa

Para determinar com parcimônia a influência dos Valores Humanos nas variáveis dependentes foram realizadas regressões passo a passo pelo método stepwise; por se tratar de uma avaliação exploratória, as sugestões de Paschoal e Tamayo (2005) se fazem válidas, uma vez que as variáveis estão sendo avaliadas em relação à sua possibilidade de compor um modelo mais parcimonioso. Assim, a regressão stepwise pelo método stepwise, que testa quais variáveis são responsáveis por contribuir pela maior variância da variável dependente de modo indiscriminado é indicada.

Faz-se necessário observar que existem variações na literatura quanto ao $\mathrm{N}$ indicado para regressões stepwise. Tabachnick e Fidell (2001) indicam que em casos em que existe forte assimetria, os dados não possuem distribuição normal e a regressão é stepwise. 40 Quarenta casos para cada variável independente seriam suficientes. Hair, Black, Babin, Anderson e Tathan (2009) sugerem 20 casos para cada variável independente como excelente, mencionando que em casos de stepwise deve ser superior 20 casos por variável 
independente. Como os dados não possuem assimetria e atendem aos critérios de normalidade, excluiu-se o pior cenário de 40 casos para cada variável dependente recorrendo ao software Gpower 3.1 para determinar a quantidade mínima de sujeitos da pesquisa. Considerando as recomendações de Cohen (1992) de poder estatístico acima de 0,80, a amostra mínima seria de 155 sujeitos em cada país, sendo, assim, consideradas excelentes as amostras de 450 sujeitos nos Estados Unidos da América e 560 no Brasil.

Foram realizadas regressões stepwise utilizando os tipos de julgamento, atribuição de significado e atributos tangíveis do carro como variáveis dependentes e os Valores Humanos e idade foram utilizados como variáveis independentes, para observar de modo mais específico a influência dos Valores Humanos e idade nas variáveis dependentes no Brasil e nos Estados Unidos da América. As recomendações de Abbad e Torres (2002) foram seguidas para as regressões pelo método stepwise e $\mathrm{Sr}^{2}$ foi reportado em todas as regressões que resultaram em mais de uma variável independente, predizendo a variável dependente, pois o $\mathrm{Sr}^{2}$ representa a contribuição isolada de cada uma das VIs no modelo; quando a soma da contribuição isolada das variáveis é consideravelmente superior ao $\mathrm{R}^{2}$ do modelo e os betas apresentam valores opostos, pode-se inferir que ocorreu supressão de uma variável pela outra. Apesar de algumas regressões apresentarem soma de $\mathrm{Sr}^{2}$ não foi caracterizado o fenômeno de regressão, pois os betas mantiveram os mesmos sinais.

Considerando no Brasil o Julgamento Afetivo acerca de automóveis foi predito por Hedonismo e Poder sobre Recursos, sendo que Hedonismo apresentou um $\mathrm{R}^{2}$ de 0,10 e conjuntamente com Poder sobre Recursos um $\mathrm{R}^{2}$ de 0,13 . A tabela 29 apresenta os resultados da regressão stepwise para Julgamento afetivo predito por Valores Humanos.

Tabela 29

Regressão stepwise para Julgamento afetivo predito por Valores Humanos no Brasil

\begin{tabular}{|c|c|c|c|c|c|c|c|c|}
\hline Modelo & VD & VI & $\mathbf{R}\left(\mathbf{R}^{2}\right)$ & $\mathrm{Sr}^{2}$ & Variáveis & $\boldsymbol{\beta}$ & sig & $\begin{array}{c}\text { Teste } \\
\text { Estatístico }\end{array}$ \\
\hline 1 & $\begin{array}{c}\text { Julgamento } \\
\text { Afetivo }\end{array}$ & $\begin{array}{l}\text { Valores } \\
\text { Humanos }\end{array}$ & $\begin{array}{c}0,33 \\
(0,10)\end{array}$ & 0,33 & $\mathrm{HE}$ & 0,3 & 0 & $\begin{array}{c}\mathrm{F}=33,63 \\
\mathrm{p}=0,000\end{array}$ \\
\hline 2 & $\begin{array}{c}\text { Julgamento } \\
\text { Afetivo }\end{array}$ & $\begin{array}{l}\text { Valores } \\
\text { Humanos }\end{array}$ & $\begin{array}{c}0,36 \\
(0,13)\end{array}$ & $\begin{array}{l}0,25 \\
0,19\end{array}$ & POR & 0,3 & 0 & $\begin{array}{c}F=22,98 \\
p=0,00\end{array}$ \\
\hline
\end{tabular}

Fonte: Dados da pesquisa

Para Julgamento Passo a Passo a respeito de automóveis a Segurança Pessoal apresentou $\mathrm{R}^{2}$ de 0,08 . A tabela 30 apresenta os resultados da regressão stepwise para Julgamento Passo a Passo predito por Valores Humanos. 
Tabela 30

Regressão stepwise para Julgamento Passo a Passo predito por Valores Humanos no Brasil

\begin{tabular}{cccccccc}
\hline Modelo & VD & VI & R $\left(\mathbf{R}^{2}\right)$ & Variáveis & $\boldsymbol{\beta}$ & sig & $\begin{array}{c}\text { Teste } \\
\text { Estatístico }\end{array}$ \\
\hline \multirow{2}{*}{1} & $\begin{array}{c}\text { Julgamento Passo a } \\
\text { Passo }\end{array}$ & $\begin{array}{c}\text { Valores } \\
\text { Humanos }\end{array}$ & $\begin{array}{c}0,29 \\
(0,09)\end{array}$ & SEP & 0,3 & 0 & $\begin{array}{c}\mathrm{F}=26,57 ; \\
\mathrm{p}=0,000\end{array}$ \\
\hline
\end{tabular}

Fonte: Dados da pesquisa.

Considerando Significado Simbólico a respeito de automóveis, o Valor Humano de Poder Sobre Recursos resultou em um $\mathrm{R}^{2}$ de 0,47. A tabela 31 apresenta os resultados da regressão stepwise para Significado Simbólico predito por Valores Humanos.

Tabela 31

Regressão stepwise para Significado Simbólico predito por Valores Humanos no Brasil

\begin{tabular}{cccccccc}
\hline Modelo & VD & VI & R $\left(\mathbf{R}^{2}\right)$ & Variáveis & $\boldsymbol{\beta}$ & sig & Teste Estatístico \\
\hline \multirow{2}{*}{1} & Significado & Valores & 0,69 & \multirow{2}{*}{ POR } & \multirow{2}{*}{0,7} & \multirow{2}{*}{0} & $\mathrm{~F}=277,93 ;$ \\
& Simbólico & Humanos & $(0,47)$ & & & $\mathrm{p}=0,000$ \\
\hline
\end{tabular}

Fonte: Dados da pesquisa.

Para Significado Utilitário em automóveis o Valor Humano de Poder de Domínio apresentou $\mathrm{R}^{2}$ de 0,05 . A tabela 32 apresenta os resultados da regressão stepwise para Significado Utilitário predito por Valores Humanos.

Tabela 32

Regressão stepwise para Significado Utilitário predito por Valores Humanos no Brasil

\begin{tabular}{cccccccc}
\hline Modelo & VD & VI & $\mathbf{R}\left(\mathbf{R}^{2}\right)$ & Variáveis & $\boldsymbol{\beta}$ & sig & $\begin{array}{c}\text { Teste } \\
\text { Estatístico }\end{array}$ \\
\hline \multirow{2}{*}{1} & $\begin{array}{c}\text { Significado } \\
\text { Utilitário }\end{array}$ & $\begin{array}{c}\text { Valores } \\
\text { Humanos }\end{array}$ & $\begin{array}{c}0,24 \\
(0,06)\end{array}$ & POD & 0,2 & 0 & $\begin{array}{c}\mathrm{F}=18,15 ; \\
\mathrm{p}=0,000\end{array}$ \\
\hline
\end{tabular}

Fonte: Dados da pesquisa.

Considerando os atributos tangíveis do carro no Brasil como variável dependente e Valores Humanos como Variáveis independentes, Segurança Pessoal apresentou $\mathrm{R}^{2}$ de 0,21. A tabela 33 apresenta os resultados da regressão stepwise para atributos tangíveis do carro predito por Valores Humanos. 
Tabela 33

Regressão stepwise para atributos tangíveis do carro predito por Valores Humanos no Brasil

\begin{tabular}{cccccccc}
\hline Modelo & VD & VI & $\mathbf{R}\left(\mathbf{R}^{2}\right)$ & Variáveis & $\boldsymbol{\beta}$ & sig & $\begin{array}{c}\text { Teste } \\
\text { Estatístico }\end{array}$ \\
\hline \multirow{2}{*}{1} & $\begin{array}{c}\text { Atributos tangíveis do } \\
\text { carro }\end{array}$ & $\begin{array}{c}\text { Valores } \\
\text { Humanos }\end{array}$ & $\begin{array}{c}0,46 \\
(0,21)\end{array}$ & SEP & 0,5 & 0 & $\begin{array}{c}\mathrm{F}=34,48 ; \\
\mathrm{p}=0,000\end{array}$ \\
\hline
\end{tabular}

Fonte: Dados da pesquisa

Considerando os sujeitos analisados nos Estados Unidos da América, as mesmas regressões foram realizadas, a saber, os tipos de julgamento, atribuição de significado e atributos tangíveis do carro como variáveis dependentes e Valores Humanos e idade como variáveis independentes. Para Julgamento Afetivo acerca de automóveis nos Estados Unidos da América os Valores Humanos de Realização apresentaram um $\mathrm{R}^{2}$ de 0,17 e Hedonismo conjuntamente com Realização apresentaram um $\mathrm{R}^{2}$ de 0,20. A tabela 34 apresenta os resultados da Regressão stepwise para Julgamento Afetivo como variável dependente e Valores Humanos e idade como variáveis independentes nos Estados Unidos da América.

Tabela 34

Regressão stepwise para Julgamento afetivo predito por Valores Humanos nos Estados Unidos da América

\begin{tabular}{|c|c|c|c|c|c|c|c|c|}
\hline Modelo & VD & VI & $\mathbf{R}\left(\mathbf{R}^{2}\right)$ & $\mathrm{Sr}^{2}$ & Variáveis & $\boldsymbol{\beta}$ & sig & $\begin{array}{c}\text { Teste } \\
\text { Estatístico }\end{array}$ \\
\hline 1 & $\begin{array}{c}\text { Julgamento } \\
\text { Afetivo }\end{array}$ & $\begin{array}{l}\text { Valores } \\
\text { Humanos }\end{array}$ & $\begin{array}{c}0,42 \\
(0,17)\end{array}$ & 0,42 & $\mathrm{HE}$ & 0,3 & 0 & $\begin{array}{c}F=33,63 \\
p=0,000\end{array}$ \\
\hline 2 & $\begin{array}{c}\text { Julgamento } \\
\text { Afetivo }\end{array}$ & $\begin{array}{l}\text { Valores } \\
\text { Humanos }\end{array}$ & $\begin{array}{c}0,46 \\
(0,21)\end{array}$ & $\begin{array}{l}0,36 \\
0,20\end{array}$ & $\begin{array}{l}\mathrm{AC} \\
\mathrm{HE}\end{array}$ & $\begin{array}{l}0,3 \\
0,2\end{array}$ & $\begin{array}{l}0 \\
0\end{array}$ & $\begin{array}{c}\mathrm{F}=22,98 \\
\mathrm{p}=0,00\end{array}$ \\
\hline
\end{tabular}

Fonte: Dados da pesquisa

Utilizando Julgamento Passo a Passo para automóveis como variável dependente nos Estados Unidos da América e Valores Humanos e idade como variáveis independentes, Segurança Pessoal resultou em um $\mathrm{R}^{2}$ de 0,03 . A tabela 35 apresenta os resultados da Regressão stepwise para Julgamento Passo a Passo como variável dependente e Valores Humanos e idade como variáveis independentes nos Estados Unidos da América. 
Tabela 35

Regressão stepwise para Julgamento Passo a Passo predito por Valores Humanos e idade nos Estados Unidos da América

\begin{tabular}{cccccccc}
\hline Modelo & VD & VI & $\mathbf{R}\left(\mathbf{R}^{2}\right)$ & Variáveis & $\boldsymbol{\beta}$ & sig & $\begin{array}{c}\text { Teste } \\
\text { Estatístico }\end{array}$ \\
\hline \multirow{2}{*}{1} & $\begin{array}{c}\text { Julgamento Passo a } \\
\text { Passo }\end{array}$ & $\begin{array}{c}\text { Valores } \\
\text { Humanos }\end{array}$ & $\begin{array}{c}0,09 \\
(0,03)\end{array}$ & SEP & 0,1 & 0 & $\begin{array}{c}\mathrm{F}=27,63 ; \\
\mathrm{p}=0,000\end{array}$ \\
\hline
\end{tabular}

Fonte: Dados da pesquisa

Em consideração a Significado Simbólico sobre automóveis como variável dependente e Valores Humanos e idade como variáveis independentes nos Estados Unidos da América, os Valor Humano de Poder Sobre Recursos apresentou um $\mathrm{R}^{2}$ de 0,43 e somado com Poder de Domínio um $\mathrm{R}^{2}$ de 0,46. A tabela 36 apresenta os resultados da regressão stepwise para Significado Simbólico como variável dependente e Valores Humanos e idade como variáveis independentes nos Estados Unidos da América.

Tabela 36

Regressão stepwise para Significado Simbólico predito por Valores Humanos e idade nos Estados Unidos da América

\begin{tabular}{ccccccccc}
\hline Modelo & VD & VI & $\mathbf{R}\left(\mathbf{R}^{2}\right)$ & $\mathbf{S r}^{2}$ & Variáveis & $\boldsymbol{\beta}$ & sig & $\begin{array}{c}\text { Teste } \\
\text { Estatístico }\end{array}$ \\
\hline \multirow{2}{*}{1} & Significado & Valores & 0,66 & \multirow{2}{*}{0,66} & POR & 0,3 & 0 & $\mathrm{~F}=33,63 ;$ \\
& Simbólico & Humanos & $(0,43)$ & & & & \\
\multirow{2}{*}{2} & Significado & Valores & 0,68 & 0,51 & POR & 0,3 & 0 & $\mathrm{~F}=22,98$ \\
& Simbólico & Humanos & $(0,46)$ & 0,23 & POD & 0,2 & 0 & $\mathrm{p}=0,00$ \\
\hline
\end{tabular}

Fonte: Dados da pesquisa

Em análise a Significado Utilitário para automóveis nos Estados Unidos da América como variável dependente e Valores Humanos e idade como variáveis independentes, o Valor Humano de Poder Sobre Recursos resultou em um $\mathrm{R}^{2}$ de 0,08 . A tabela 37 apresenta os resultados da regressão stepwise para Significado Utilitário como variável dependente e Valores Humanos e idade como variáveis independentes nos Estados Unidos da América. 
Tabela 37

Regressão stepwise para Significado Utilitário predito por Valores Humanos e idade nos Estados Unidos da América

\begin{tabular}{ccccccccc}
\hline Modelo & VD & VI & $\mathbf{R}\left(\mathbf{R}^{2}\right)$ & Variáveis & $\boldsymbol{\beta}$ & sig & Teste Estatístico \\
\hline \multirow{2}{*}{1} & Significado & Valores & 0,28 & POR & 0,1 & 0 & $\begin{array}{c}\text { F }=51,10 ; \\
\mathrm{p}=0,000\end{array}$ \\
\hline
\end{tabular}

Fonte: Dados da pesquisa

Finalmente, considerando os atributos tangíveis do carro nos Estados Unidos da América como variável dependente e Valores Humanos como Variáveis independentes, Segurança Pessoal apresentou $\mathrm{R}^{2}$ de 0,16 . A tabela 38 apresenta os resultados da regressão stepwise para atributos tangíveis do carro predito por Valores Humanos.

Tabela 38

Regressão stepwise para atributos tangíveis do carro predito por Valores Humanos nos Estados Unidos da América

\begin{tabular}{cccccccc}
\hline Modelo & VD & VI & $\begin{array}{c}\mathbf{R} \\
\left(\mathbf{R}^{2}\right)\end{array}$ & Variáveis & $\boldsymbol{\beta}$ & sig & Teste Estatístico \\
\hline \multirow{2}{*}{1} & Atributos tangíveis do & Valores & 0,4 & SEP & 0 & 0 & $\begin{array}{c}\text { F }=56,32 ; \\
\mathrm{p}=0,000\end{array}$ \\
\hline
\end{tabular}

Fonte: Dados da pesquisa

Concluídas as regressões para estabelecer a relação das escalas de Valores Humanos, Pessoais e ambas em Conjunto, as regressões para determinar de modo específico quais Valores Humanos melhor se relacionam com as variáveis da escala de Julgamento e Significado, procedeu-se à análise confirmatória das escalas utilizadas tanto no Brasil quanto nos Estados Unidos da América, culminando com a análise de caminhos, aplicando o Modelo de Duas Rotas acrescido de idade e os Valores Humanos que se destacaram nas regressões passo a passo.

\subsection{Análise fatorial confirmatória}

Como critério anterior à análise de caminhos, Marôco (2010) recomenda que sejam realizadas análises fatoriais confirmatórias, onde os construtos a serem utilizados são testados sem que seja realizada ainda uma relação entre as diversas variáveis, ou seja, de modo independente os construtos são verificados. Para elaborar essa estimação, foram seguidas as recomendações de Marôco (2010) que aponta que o modelo mais tradicional e mais utilizado para análise fatorial confirmatória e análise de caminhos é o de Máxima Verossimilhança 
(ML) ou Maximum Likelihood. Brown (2006) aponta que os pressupostos fundamentais da ML são o tamanho grande da amostra, a distribuição multivariadas dos dados e o fao de as variáveis serem contínuas.

Quanto ao tamanho da amostra, 562 respondentes no Braisl e 450 nos Estados Unidos da América atendem o pressuposto de tamanho da amostra, uma vez que Hair, Black, Babin, Anderson e Tathan (2009) recomendam que o tamanho ideal para realizar modelagem por equações estruturais é pelo menos 200. Os dados foram coletados aplicando escalas tipo likert, atendendo ao pressuposto de variáveis contínuas. A subseção 7.1 apresenta as avaliações de normalidade dos construtos, indicando que existe normalidade ainda que Marôco (2010) aponte que o método de Máxima Verossimilhança é robusto quanto à violação da normalidade desde que esta não seja extrema.

\subsubsection{Análise confirmatória dos tipos de julgamento e atribuição de significado}

A escala de julgamento e significado proposta por Allen (1997), Julgamento Afetivo, Julgamento Passo a Passo, Significado Simbólico e Significado Utilitário são compostos respectivamente por 5 itens, 6 itens, 6 itens e 3 itens. Marôco (2010) recomenda que se observe o CFI (Comparative Fit Index), pois compara o ajustamento do modelo em estudo $\left(\mathrm{X}^{2}\right)$ com graus de liberdade com modelo basal $\left(\mathrm{X}^{2} \mathrm{~b}\right)$ e com graus de liberdade G.Lb, o que significa uma comparação entre o modelo completamente independente e o correlacionado. Um CFI maior ou igual a 0,90 indica bom ajustamento do modelo. Outro índice recomendado por Marôco (2010) é o RMSEA (Root Mean Square Error of Approximation), pois, de maneira geral, afirma que a adição de variáveis em um modelo melhora a estimação dos índices e o RMSEA apresenta um índice que penaliza a adição de graus de liberdade para compensar a melhoria obtida pela simples adição destes.

Marôco (2010) sugere que o RMSEA é bom para valores abaixo de 0,08 e muito bom quando abaixo de 0,05. Marôco (2010) aponta que é interessante observar o SRMR (Standardized Root Mean Square Residual), a raiz quadrada da matriz dos erros divida pelos graus de liberdade, assumindo que o modelo ajustado é o correto; um SRMR equivalente a 0 indica ajuste perfeito do modelo, SRMR abaixo ou igual a 0,05 indica excelente ajuste, valores entre 0,05 e 0,08 indicam bons ajustes e valores superiores a 0,1 indicam ajustes inadequados. Por fim, outro indicador de ajuste refere-se ao $\mathrm{X}^{2} / \mathrm{G}$.L (Qui-quadrado dividido por graus de liberdade), e Marôco 2010 aponta que valores entre 2 e 5 são aceitaveis, inferiores a 2 bons e acima de 5 inaceitáveis. 
A análise confirmatória para Significado e Julgamento (Allen, 1997) resultou em $X^{2} / G$.L acima de 2,0 no Brasil $X^{2} / G . L=3,20$ o que indica ajuste aceitável da estrutura. Os índices de ajuste são considerados insatisfatórios, uma vez que $\mathrm{CFI}=0,85, \mathrm{RMSEA}=0,82$ e $R M R=0,17$. A figura 20 apresenta a estrutura confirmatória da escala de Significado e julgamento (Allen, 1997) em sua forma teórica original.
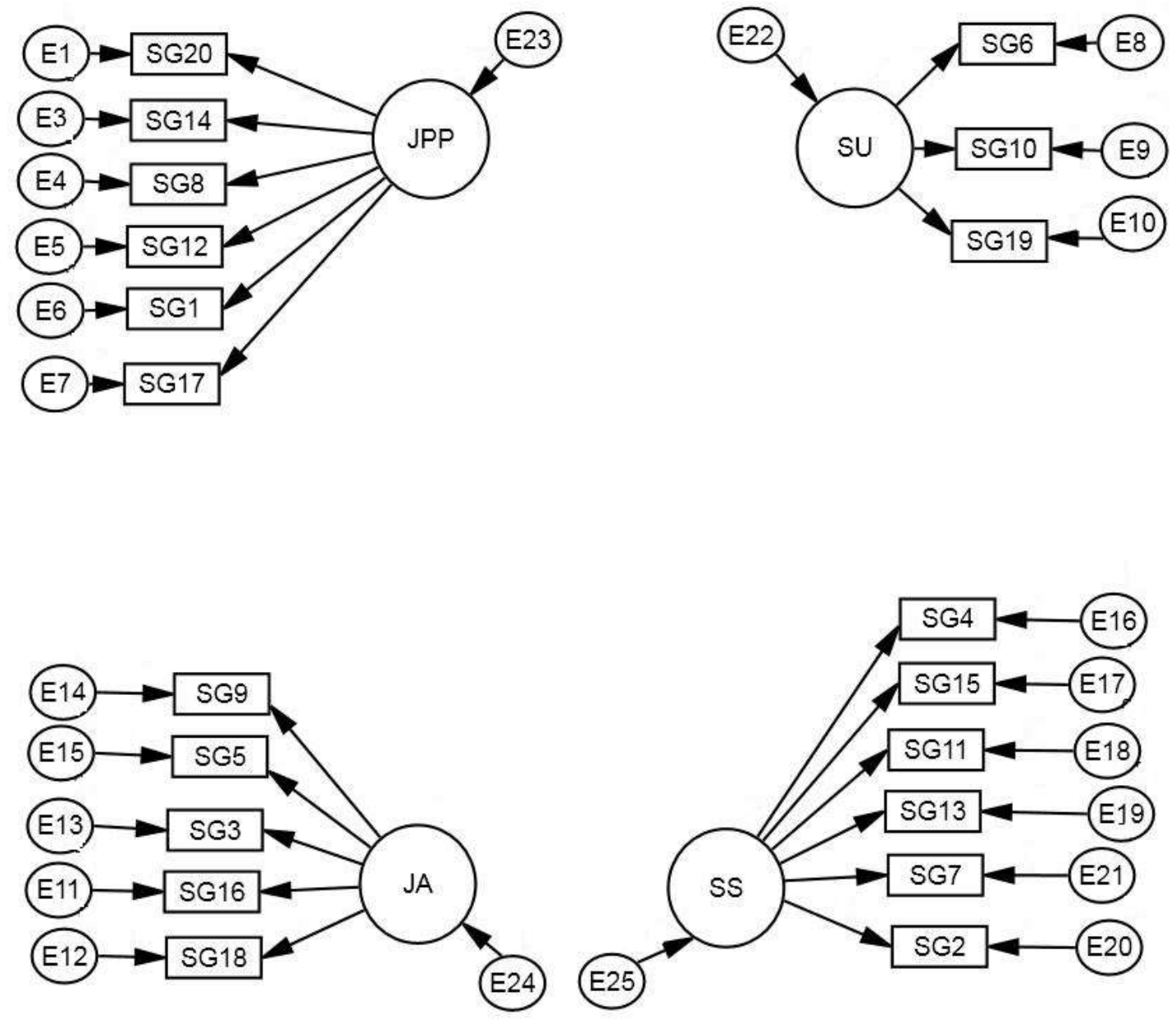

Figura 20. Estimativa da AFC da Escala de Significado e Julgamento no Brasil Fonte: Dados da Pesquisa

A tabela 39 apresenta os índices de estimação do modelo teórico da escala de Significado e Julgamento (Allen, 2006b), em seus respectivos fatores no Brasil. Observa-se que os itens pertencem aos fatores listados da escala de significado e julgamento. 
Tabela 39

Indices de estimação do modelo teórico da escala de Significado e Julgamento em seus respectivos fatores no Brasil

\begin{tabular}{|c|c|c|c|c|c|}
\hline & Estimação & $\begin{array}{c}\text { Erros } \\
\text { padronizados } \\
\text { (S.E.) } \\
\end{array}$ & C.R. & P-valor & $\begin{array}{c}\text { Estimação da regressão } \\
\text { padronizada }\end{array}$ \\
\hline \multicolumn{6}{|c|}{ Julgamento Afetivo } \\
\hline SG9 & 1 & & & & 0,63 \\
\hline SG5 & 0,83 & 0,11 & 7,51 & 0 & 0,53 \\
\hline SG3 & 0,88 & 0,08 & 7,97 & 0 & 0,57 \\
\hline SG16 & 1,22 & 0,13 & 9,41 & 0 & 0,74 \\
\hline SG18 & 1,3 & 0,14 & 9,25 & 0 & 0,71 \\
\hline \multicolumn{6}{|c|}{ Julgamento Passo a Passo } \\
\hline SG20 & 1 & & & & 0,78 \\
\hline SG14 & 0,99 & 0,08 & 12,8 & 0 & 0,79 \\
\hline SG8 & 0,78 & 0,08 & 9,91 & 0 & 0,6 \\
\hline SG12 & 0,75 & 0,12 & 6,22 & 0 & 0,38 \\
\hline SG1 & 0,66 & 0,09 & 7,69 & 0 & 0,47 \\
\hline SG17 & & & & & 0,71 \\
\hline \multicolumn{6}{|c|}{ Significado Simbólico } \\
\hline SG4 & 1 & & & & 0,76 \\
\hline SG15 & 1,12 & 0,08 & 14,2 & 0 & 0,81 \\
\hline SG11 & 0,78 & 0,08 & 9,96 & 0 & 0,76 \\
\hline SG13 & 0,88 & 0,07 & 12,1 & 0 & 0,69 \\
\hline SG7 & 1,05 & 0,07 & 12,1 & 0 & 0,8 \\
\hline SG2 & 1 & 0,08 & 12,9 & 0 & 0,74 \\
\hline \multicolumn{6}{|c|}{ Significado Utilitário } \\
\hline SG6 & 1 & & & & 0,85 \\
\hline SG10 & 1,2 & 0,17 & 6,91 & 0 & 0,62 \\
\hline SG19 & 1,63 & 0,28 & 5,84 & 0 & 0,49 \\
\hline
\end{tabular}

Fonte: Dados da pesquisa

Em situações como esta de $X^{2} / G . L>2,0$ Marôco (2010) recomenda observar os índices de modificação (Modification Indeces), uma vez que estes apontam a redução conservadora do $\mathrm{X}^{2}$ do modelo se um parâmetro fixo ou uma igualdade de parâmetros for liberado, se erros de medida forem correlacionados depois da reestimação do modelo. No caso do Brasil, uma variável, SG19 foi excluída do modelo. No novo modelo os índices obtidos foram de $\mathrm{X}^{2} / \mathrm{G} . \mathrm{L}=2,5, \mathrm{CFI}=0,90$ e RMSEA=0,068, índices considerados melhores que o modelo original.Todas as variáveis inseridas são significativas pois seu p-valor foi abaixo de 0,05, como aponta Marôco (2010), e o critical ratio (C.R) atendeu ao padrão estabelecido por Byrne (2010) que destaca que este deve ser superior a 1,96. 
Nos Estados Unidos da América, o modelo teórico resultou em $\mathrm{X}^{2} / \mathrm{G} . \mathrm{L}=4,88$, $\mathrm{CFI}=0,78, \mathrm{RMSEA}=0,12$ e SRMR=0,21, índices inadequados. A tabela 40 apresenta os índices de estimação do modelo teórico da escala de Significado e Julgamento (Allen, 2006b), em seus respectivos fatores nos Estados Unidos da América. Após inspeção da tabela, recomendou-se retirar do modelo SG19 por não ser significativo na regressão.

Tabela 40

Estimativas da análise fatorial confirmatória da escala de Significado e Julgamento nos Estados Unidos da América

\begin{tabular}{|c|c|c|c|c|c|}
\hline & Estimação & $\begin{array}{c}\text { Erros } \\
\text { padronizados } \\
\text { (S.E.) } \\
\end{array}$ & C.R. & P-valor & $\begin{array}{c}\text { Estimação da regressão } \\
\text { padronizada }\end{array}$ \\
\hline \multicolumn{6}{|c|}{ Julgamento Afetivo } \\
\hline SG9 & 1 & & & & 0,57 \\
\hline SG5 & 0,83 & 0,14 & 9,41 & 0 & 0,55 \\
\hline SG3 & 1,28 & 0,13 & 9,7 & 0 & 0,62 \\
\hline SG16 & 1,5 & 0,15 & 9,85 & 0 & 0,64 \\
\hline SG18 & 1 & & & & 0,33 \\
\hline \multicolumn{6}{|c|}{ Julgamento Passo a Passo } \\
\hline SG20 & 1,01 & 0,05 & 20,8 & 0 & 0,82 \\
\hline SG14 & 1 & & & & 0,74 \\
\hline SG8 & 0,71 & 0,04 & 15,7 & 0 & 0,58 \\
\hline SG12 & 0,87 & 0,08 & 10,6 & 0 & 0,33 \\
\hline SG1 & 0,7 & 0,06 & 7,69 & 0 & 0,34 \\
\hline SG17 & & & & & 0,63 \\
\hline \multicolumn{6}{|c|}{ Significado Simbólico } \\
\hline SG4 & 1 & 0,13 & 10,9 & & 0,62 \\
\hline SG15 & 1,08 & 0,11 & 9,84 & 0 & 0,47 \\
\hline SG11 & 1,48 & 0,13 & 11,2 & 0 & 0,68 \\
\hline SG13 & 1,31 & 0,12 & 10,6 & 0 & 0,57 \\
\hline SG7 & 1,35 & 0,12 & 11,3 & 0 & 0,7 \\
\hline SG2 & 1 & & & & 0,39 \\
\hline \multicolumn{6}{|c|}{ Significado Utilitário } \\
\hline SG6 & 1 & & & & 0,7 \\
\hline SG10 & 0,89 & 0,27 & 2,39 & 0 & 0,28 \\
\hline SG19 & 0,2 & 0,15 & 1,28 & 0,2 & 0,02 \\
\hline
\end{tabular}

Fonte: Dados da pesquisa

Após a retirada da variável SG19 por não ser significativa no modelo, foi retirada a variável SG2 por possuir o maior índice de modificação $(32,94)$, pois Byrne (2010) argumenta que parâmetros fixos com altos índices de modificação são os maiores candidatos a serem retirados do modelo. Após a retirada de ambas as variáveis do modelo, a análise 
confirmatória apresentou índices adequados; assim, o modelo confirmatório da escala de Julgamento e Significado nos Estados Unidos da América resultou em X2/G.L=3,00, $\mathrm{CFI}=0,90, \mathrm{RMSEA}=0,08$ e SRMR=0,08. Todas as variáveis inseridas são significativas, pois seu p-valor foi abaixo de 0,05 como aponta Marôco (2010) e o critical ratio (C.R) também atendeu ao padrão estabelecido por Byrne (2010), que destaca que este deve ser superior a 1,96 .

Após ambos os modelos, no Brasil e Estados Unidos da América, obterem índices adequados que indicam a estrutura confirmatória dos fatores, procedeu-se à análise da validade discriminante e convergente. Marôco (2010) aponta que a validade convergente é demonstrada quando o construto se correlaciona positivamente e negativamente com outros construtos teoricamente paralelos e quando os itens que constituem o construto apresentam correlações positivas e elevadas entre sí. Já a validade discriminante avalia se os itens que refletem um fator não estão correlacionados com outros fatores, ou seja, se os fatores paralelos definidos por cada conjunto de itens são distintos (Marôco, 2010).

Para calcular e avaliar as validades convergente e discriminante foram adotadas sugestões de Marôco (2010) que aponta que a validade convergente deve ser calculada pelo $\rho$ de Jöreskog e este deve ser igual a 0,5; e, para calcular a validade discriminante a variância extraída média (VEM) deve ser maior do que a correlação entre os fatores avaliados elevada ao quadrado. A tabela 41 apresenta os valores encontrados no Brasil, apontando que os fatores possuem $\rho$ de Jöreskog acima de 0,5 e sua correlação elevada ao quadrado é inferior à VEM, portanto sendo convergentes e discriminantes.

Tabela 41

Validade convergente e discriminante dos fatores da escala de Julgamento e Significado no Brasil

\begin{tabular}{|c|c|c|c|c|c|}
\hline \multicolumn{6}{|c|}{ Validade discriminante } \\
\hline Construtos & $\begin{array}{c}\rho \text { de } \\
\text { Jöreskog }\end{array}$ & $\begin{array}{c}\text { Julgamento } \\
\text { passo a } \\
\text { passo }\end{array}$ & $\begin{array}{c}\text { Significado } \\
\text { Utilitário }\end{array}$ & $\begin{array}{c}\text { Julgamento } \\
\text { Afetivo }\end{array}$ & $\begin{array}{c}\text { Significado } \\
\text { Simbólico }\end{array}$ \\
\hline Julgamento passo a passo & 0,55 & 0,2 & & & \\
\hline Significado Utilitário & 0,5 & 0,16 & $0,20^{*}$ & & \\
\hline Julgamento Afetivo & 0,51 & 0,09 & 0,2 & 0,25 & \\
\hline Significado Simbólico & 0,72 & 0 & 0,1 & 0,2 & 0,3 \\
\hline
\end{tabular}

Fonte: Dados da pesquisa.O Rhô da validade convergente está localizado na diagonal e as correlações entre os construtos elevadas ao quadrado estão fora da diagonal

Considerando os Estados Unidos da América, os procedimentos foram repetidos para calcular o $\rho$ de Jöreskog e a validade discriminante. Os resultados apontam que nenhum 
$\rho$ de Jöreskog ficou abaixo de 0,50 e validade discriminante foi confirmada como apresenta a tabela 42 a seguir:

Tabela 42

Validade convergente e discriminante dos fatores da escala de Julgamento e Significado nos Estados Unidos da América

\begin{tabular}{cccccc}
\hline \multicolumn{5}{c}{ Validade discriminante } \\
\hline Construtos & $\boldsymbol{\rho}$ de Jöreskog & $\begin{array}{c}\text { Julgamento } \\
\text { passo a passo }\end{array}$ & $\begin{array}{c}\text { Significado } \\
\text { Utilitário }\end{array}$ & $\begin{array}{c}\text { Julgamento } \\
\text { Afetivo }\end{array}$ & $\begin{array}{c}\text { Significado } \\
\text { Simbólico }\end{array}$ \\
\hline Julgamento passo a passo & 0,76 & 0,37 & & & \\
Significado Utilitário & 0,5 & 0,08 & 0,35 & & \\
Julgamento Afetivo & 0,68 & 0 & 0,09 & 0,31 & \\
Significado Simbólico & 0,75 & 0,01 & 0,01 & 0,35 & 0,38 \\
\hline
\end{tabular}

Fonte: Dados da pesquisa. O Rhô da validade convergente está localizado na diagonal e as correlações entre os construtos elevadas ao quadrado estão fora da diagonal

\subsubsection{Análise confirmatória dos Valores Humanos do modelo}

Após a análise confirmatória das variáveis de significado e julgamento que compõe o modelo geral estudado, foi realizada a análise fatorial conformatória (AFC), a validade convergente e a validade discriminante dos Valores Humanos que contribuiram com a predição dos tipos de julgamento e atribuição de significado no Brasil e Estados Unidos da América nas regressões passo a passo realizadas na subseção 7.4. Logo, para a análise no Brasil foram averiguados Segurança Pessoal (SEP), Hedonismo (HE) e Poder sobre Recursos (POR). A tabela 43 apresenta as estimativas dos Valores Humanos presentes no modelo no Brasil: 
Tabela 43

Estimativas da análise fatorial confirmatória dos Valores Humanos aplicado no modelo geral no Brasil

\begin{tabular}{cccccc}
\hline & Estimação & $\begin{array}{c}\text { Erros padronizados } \\
\text { (S.E.) }\end{array}$ & C.R. & $\begin{array}{c}\text { P- } \\
\text { valor }\end{array}$ & $\begin{array}{c}\text { Estimação da regressão } \\
\text { padronizada }\end{array}$ \\
\hline Segurança Pessoal & & 1,33 & 1,97 & 0,05 & 0,67 \\
PVQR26_1 & 2,55 & 1,24 & 2 & 0 & 0,49 \\
PVQR13_1 & 0,7 & & & & 0,55 \\
PVQR53_1 & 1 & & & & \\
Hedonismo & & 0,23 & 6,13 & 0 & 0,45 \\
PVQR36_1 & 1,43 & 0,31 & 6,1 & 0 & 0,41 \\
PVQR46_1 & 1,89 & & & & 0,61 \\
PVQR3_1 & 1 & & & & \\
Poder sobre & & & & & 0,58 \\
Recursos & & & & & 0,62 \\
PVQR44_1 & 1 & 0,1 & 11,5 & 0 & 0,53 \\
PVQR20_1 & 1,12 & 0,09 & 11,1 & 0 & \\
PVQR12_1 & 0,99 & & &
\end{tabular}

Fonte:Dados da pesquisa

Os índices obtidos no modelo confirmatório dos Valores Humanos presente no modelo geral no Brasil foi satisfatório, uma vez que X2/G.L=2,78, CFI=0,93, RMSEA=0,07 e SRMR=0,05. O p-valor das variáveis apresentou-se abaixo de 0,05 e o C.R acima de 1,96.

Procedeu-se à análise discriminatória e convergente dos fatores; todos os valores apontam que nenhum $\rho$ de Jöreskog ficou abaixo de 0,50 e a validade discriminante foi confirmada, pois a correlação quadrática entre os fatores é inferior ao Rhô da validade convergente de cada um dos Valores Humanos como apresenta a tabela 44.

Tabela 44

Validade convergente e discriminante dos fatores da Valores Humanos presentes no modelo no Brasil

\begin{tabular}{|c|c|c|c|c|}
\hline \multicolumn{4}{|c|}{ Validade discriminante } & \multirow[b]{2}{*}{$\begin{array}{c}\text { Poder } \\
\text { sobre } \\
\text { Recursos }\end{array}$} \\
\hline Construtos & $\begin{array}{c}\rho \text { de } \\
\text { Jöreskog }\end{array}$ & $\begin{array}{c}\text { Segurança } \\
\text { Pessoal }\end{array}$ & Hedonismo & \\
\hline Segurança Pessoal & 0,5 & 0,33 & & \\
\hline Hedonismo & 0,51 & 0,31 & 0,26 & \\
\hline Poder sobre Recursos & 0,6 & 0 & 0,23 & 0,33 \\
\hline
\end{tabular}

Fonte: Dados da pesquisa. (O Rhô da validade convergente está localizado na diagonal e as correlações entre os construtos elevadas ao quadrado estão fora da diagonal) 
Considerando os Estados Unidos da América os Valores Humanos de Poder Sobre Recursos (POR), Hedonismo (HE), Realização (AC) e Segurança Pessoal (SEP) foram averiguados quanto à sua estrutura fatorial de modo confirmatório e sua validade convergente e discriminante checada. A tabela 45 apresenta as estimativas dos Valores Humanos presentes no modelo nos Estados Unidos da América.

Tabela 45

Estimativas da análise fatorial confirmatória dos Valores Humanos aplicado no modelo geral nos Estados Unidos da América

\begin{tabular}{|c|c|c|c|c|c|}
\hline & Estimação & $\begin{array}{c}\text { Erros } \\
\text { padronizados } \\
\text { (S.E.) } \\
\end{array}$ & C.R. & $\begin{array}{c}\text { P- } \\
\text { valor }\end{array}$ & $\begin{array}{c}\text { Estimação da regressão } \\
\text { padronizada }\end{array}$ \\
\hline \multicolumn{6}{|c|}{ Segurança Pessoal } \\
\hline PVQR26_1 & 1,26 & 0,18 & 6,62 & 0 & 0,79 \\
\hline PVQR13_1 & 1 & & & & 0,62 \\
\hline PVQR53_1 & 1,23 & 0,18 & 6,63 & 0 & 0,52 \\
\hline \multicolumn{6}{|c|}{ Hedonismo } \\
\hline PVQR36_1 & 0,82 & 0,06 & 12,8 & 0 & 0,78 \\
\hline PVQR46_1 & 1 & & & & 0,79 \\
\hline PVQR3_1 & 0,94 & 0,07 & 13,1 & 0 & 0,82 \\
\hline \multicolumn{6}{|c|}{ Poder sobre Recursos } \\
\hline PVQR44_1 & 0,89 & 0,06 & 15,5 & 0 & 0,8 \\
\hline PVQR20_1 & 1 & & & & 0,86 \\
\hline PVQR12_1 & 0,93 & 0,06 & 15,5 & 0 & 0,83 \\
\hline \multicolumn{6}{|c|}{ Realização } \\
\hline PVQR17_1 & 1 & & & & 0,87 \\
\hline PVQR32_1 & 1,43 & 0,15 & 12,3 & 0 & 0,87 \\
\hline PVQR48_1 & 1 & 0,13 & 14,9 & 0,2 & 0,83 \\
\hline
\end{tabular}

Fonte: Dados da pesquisa

Os índices obtidos no modelo confirmatório dos Valores Humanos presente no modelo geral nos Estados Unidos da América foi satisfatório, uma vez que X2/G.L=3,00, $\mathrm{CFI}=0,93, \mathrm{RMSEA}=0,08$ e SRMR=0,06. Todos os $\mathrm{p}$-valor das variáveis inseridas resultaram em valores abaixo de 0,05 e os C.R em valores superiores a 1.96.

Procedeu-se à análise discriminatória e convergente dos fatores; todos os valores apontam que nenhum $\rho$ de Jöreskog ficou abaixo de 0,50 e validade discriminante foi confirmada, pois a correlação quadrática entre os fatores é inferior ao Rhô da validade convergente de cada um dos Valores Humanos como apresenta a tabela 46. 
Tabela 46

Validade convergente e discriminante dos fatores da Valores Humanos presentes no modelo no Brasil

\begin{tabular}{cccccc}
\hline \multicolumn{6}{c}{ Validade discriminante } \\
\hline Construtos & $\begin{array}{c}\boldsymbol{\rho} \text { de } \\
\text { Jöreskog }\end{array}$ & $\begin{array}{c}\text { Segurança } \\
\text { Pessoal }\end{array}$ & Hedonismo & $\begin{array}{c}\text { Poder sobre } \\
\text { Recursos }\end{array}$ & Realização \\
\hline Segurança Pessoal & 0,61 & 0,26 & & & \\
Hedonismo & 0,74 & 0 & $0,37^{*}$ & & \\
Poder sobre Recursos & 0,78 & 0 & 0,1 & 0,51 & \\
Realização & 0,65 & 0,09 & 0,1 & 0,5 & 0,55 \\
\hline
\end{tabular}

Fonte: Dados da pesquisa. O Rhô da validade convergente está localizado na diagonal e as correlações entre os construtos elevadas ao quadrado estão fora da diagonal.

\subsection{Mensuração dos modelos gerais}

Após as variáveis latentes terem sido verificadas, de forma isolada, procedeu-se à realização de forma conjunta. Assim, a análise fatorial confirmatória foi elaborada com todas as variáveis que integraram ambos os modelos, no Brasil e nos Estados Unidos da América. A tabela 47 apresenta todas as estimativas para os resultados encontrados no modelo geral no Brasil. 
Tabela 47

Estimativas do Modelo Geral de consumo de veículos automotores no Brasil e tipo de julgamento e atribuição de significado

\begin{tabular}{|c|c|c|c|c|c|}
\hline & Estimação & $\begin{array}{c}\text { Erros } \\
\text { padronizad } \\
\text { os (S.E.) }\end{array}$ & C.R. & P-valor & $\begin{array}{l}\text { Estimação da } \\
\text { regressão } \\
\text { padronizada }\end{array}$ \\
\hline \multicolumn{6}{|c|}{ Segurança Pessoal } \\
\hline PVQR26_1 & 2,56 & 1,31 & 3,98 & 0,01 & 0,48 \\
\hline PVQR13_1 & 2,23 & 1,13 & 2,99 & 0,01 & 0,34 \\
\hline PVQR53_1 & 1,00 & & & & 0,60 \\
\hline \multicolumn{6}{|c|}{ Hedonismo } \\
\hline PVQR36_1 & 1,00 & & & & 0,56 \\
\hline PVQR46_1 & 1,27 & 0,17 & 7,22 & 0 & 0,49 \\
\hline PVQR3_1 & 1,08 & 0,11 & 6,04 & 0 & 0,50 \\
\hline \multicolumn{6}{|c|}{ Poder sobre Recursos } \\
\hline PVQR44_1 & 0,9 & 0,06 & 15,6 & 0 & 0,65 \\
\hline PVQR20_1 & 1 & & & & 0,73 \\
\hline PVQR12_1 & 0,93 & 0,06 & 15,5 & 0 & 0,64 \\
\hline \multicolumn{6}{|c|}{ Julgamento Passo a Passo } \\
\hline SG20 & 1,01 & 0,09 & 10,96 & 0 & 0,58 \\
\hline SG14 & 1,33 & & & & 0,58 \\
\hline SG8 & 0,79 & 0,08 & 9,09 & 0 & 0,34 \\
\hline SG12 & 0,88 & 0,13 & 6,90 & 0 & 0,19 \\
\hline SG1 & 0,76 & 0,09 & 8,11 & & 0,27 \\
\hline SG17 & 1,00 & 0,08 & 11,74 & 0 & 0,60 \\
\hline \multicolumn{6}{|c|}{ Significado Utilitário } \\
\hline SG6 & 1 & & & & 0,60 \\
\hline SG10 & 1,35 & 0,51 & 8,66 & 0,01 & 0,50 \\
\hline \multicolumn{6}{|c|}{ Julgamento Afetivo } \\
\hline SG9 & 0,75 & 0,08 & 9,23 & 0 & 0,39 \\
\hline SG5 & 0,66 & 0,08 & 8,30 & 0 & 0,30 \\
\hline SG3 & 0,70 & 0,08 & 8,82 & 0 & 0,34 \\
\hline SG16 & 0,93 & 0,09 & 9,09 & 0 & 0,52 \\
\hline SG18 & 1 & & & & 0,50 \\
\hline \multicolumn{6}{|c|}{ Significado Simbólico } \\
\hline SG4 & 1,05 & 0,07 & 11,14 & 0 & 0,45 \\
\hline SG15 & 1,06 & 0,06 & 12,18 & 0 & 0,5 \\
\hline SG11 & 0,70 & 0,07 & 8,53 & 0 & 0,72 \\
\hline SG13 & 0,79 & 0,07 & 10,08 & 0 & 0,55 \\
\hline SG7 & 0,97 & 1,00 & 11,85 & & 0,62 \\
\hline SG2 & 1,00 & 1,00 & & & 0,50 \\
\hline
\end{tabular}

Fonte: Dados da pesquisa

Os índices obtidos no modelo geral confirmatório no Brasil apresentaram-se satisfatórios, pois X2/G.L=1,99, CFI=0,89, RMSEA=0,06 e SRMR=0,10 apontam ajuste 
adequado. Observa-se também que todas as variáveis inseridas são significativas, pois possuem p-valor abaixo de 0,05 e todos os C.R apresentaram-se acima de 1,96.

Considerando o modelo geral de consumo de automóveis, seu tipo de julgamento e a influência dos Valores Humanos nos tipos de julgamento e atribuição de significado nos Estados Unidos da América, a inserção de todas as variáveis que integraram o modelo foi posta em prática. A tabela 48 apresenta todas as estimativas para os resultados encontrados no modelo geral nos Estados Unidos da América. 
Tabela 48

Estimativas do Modelo Geral de consumo de veículos automotores nos Estados Unidos da América e tipo de julgamento e atribuição de significado

\begin{tabular}{|c|c|c|c|c|c|}
\hline & Estimação & $\begin{array}{c}\text { Erros } \\
\text { padronizad } \\
\text { os (S.E.) }\end{array}$ & C.R. & P-valor & $\begin{array}{l}\text { Estimação da } \\
\text { regressão } \\
\text { padronizada }\end{array}$ \\
\hline \multicolumn{6}{|c|}{ Segurança Pessoal } \\
\hline PVQR26_1 & 1,16 & 0,17 & 6,83 & 0 & 0,38 \\
\hline PVQR13_1 & 1 & & & & 0,62 \\
\hline PVQR53_1 & 1,17 & 0,18 & 6,62 & 0 & 0,3 \\
\hline \multicolumn{6}{|c|}{ Hedonismo } \\
\hline PVQR36_1 & 1,06 & 0,1 & & & 0,6 \\
\hline PVQR46_1 & 1,29 & 0,11 & 11 & 0 & 0,63 \\
\hline PVQR3_1 & 1,08 & 0,1 & 10,9 & 0 & 0,67 \\
\hline \multicolumn{6}{|c|}{ Poder sobre Recursos } \\
\hline PVQR44_1 & 0,9 & 0,06 & 15,6 & 0 & 0,65 \\
\hline PVQR20_1 & 1 & & & & 0,73 \\
\hline PVQR12_1 & 0,93 & 0,06 & 15,5 & 0 & 0,64 \\
\hline \multicolumn{6}{|c|}{ Realização } \\
\hline PVQR17_1 & 1 & & & & 0,45 \\
\hline PVQR32_1 & 1,41 & 0,15 & 7,93 & 0 & 0,62 \\
\hline PVQR48_1 & 0,99 & 0,12 & 7,93 & 0 & 0,32 \\
\hline \multicolumn{6}{|c|}{ Julgamento Passo a Passo } \\
\hline SG20 & 1,34 & 0,11 & 12 & 0 & 0,81 \\
\hline SG14 & 1,33 & 0,11 & 11,7 & 0 & 0,74 \\
\hline SG8 & 0,94 & 0,09 & 10,7 & 0 & 0,87 \\
\hline SG12 & 1,17 & 0,13 & 8,68 & 0 & 0,33 \\
\hline SG1 & 1 & & & & 0,38 \\
\hline SG17 & 1,4 & 0,14 & 9,9 & 0 & 0,65 \\
\hline \multicolumn{6}{|c|}{ Significado Utilitário } \\
\hline SG6 & 1 & & & & 0,5 \\
\hline SG10 & 0,82 & 0,25 & 8,68 & 0 & 0,5 \\
\hline \multicolumn{6}{|c|}{ Julgamento Afetivo } \\
\hline SG9 & 1,36 & 0,14 & 9,71 & 0 & 0,61 \\
\hline SG5 & 1,43 & 0,14 & 9,87 & 0 & 0,64 \\
\hline SG3 & 1,12 & 0,12 & 9,08 & 0 & 0,49 \\
\hline SG16 & 1,33 & 0,14 & 9,32 & 0 & 0,53 \\
\hline SG18 & 1 & & & & 0,34 \\
\hline \multicolumn{6}{|c|}{ Significado Simbólico } \\
\hline SG4 & 1,01 & 0,07 & 10,5 & 0 & 0,45 \\
\hline SG15 & 0,82 & 0,06 & 13,2 & 0 & 0,5 \\
\hline SG11 & 1,13 & 0,07 & 16,5 & 0 & 0,72 \\
\hline SG13 & 0,95 & 0,07 & 14 & 0 & 0,55 \\
\hline SG7 & 1 & & & & 0,7 \\
\hline
\end{tabular}

Fonte: dados da pesquisa 
Os índices obtidos no modelo geral confirmatório nos Estados Unidos da América apresentaram-se satisfatórios, pois X2/G.L=2,67, CFI=0,89, RMSEA=0,07 e SRMR=0,10 apontam ajuste razoável. Por fim, o p-valor das variáveis incluídas foi significativo (abaixo de 0,05 ) e o C.R superior a 1,96. O próximo passo consistiu em realizar a análise de caminhos com o objetivo de testar as hipóteses de pesquisa levantadas no presente trabalho.

\subsection{Modelo Estrutural}

No modelo estrutural, as relações entre os contrutos foi testada com o objetivo de comprovar o modelo geral da pesquisa. Foram inseridas as variáveis atributos tangíveis do carro, que medem os atributos tangíveis dos automóveis em ambos os países (Brasil e Estados Unidos da América) bem como a variável idade para testar a sua relação com o modelo de Duas Rotas (Allen, 1997) e os Valores Humanos presentes no modelo proposto. O critério para inserção da variável idade no modelo foi sua maior correlação apresentada na subseção 7.2 com as variáveis presentes no modelo estrutural.A variável Atributos tangíveis do carro foi inserida de acordo com sua maior correlação com o Valor Humano presente em cada modelo nos Estados Unidos da América. A tabela 49 apresenta as estimativas do do modelo estrutural para o Brasil e suas relações de predição.

Tabela 49

Estimativas do Modelo Estrutural no Brasil

\begin{tabular}{cccccc}
\hline & Estimação & $\begin{array}{c}\text { Erro padronizado } \\
\text { (S.E.) }\end{array}$ & C.R. P-valor & $\begin{array}{c}\text { Estimação da } \\
\text { regressão } \\
\text { padronizada }\end{array}$ \\
\hline $\begin{array}{c}\text { Julg. Passo a Passo } \rightarrow \\
\quad \text { Sig. Utilit. }\end{array}$ & 0,46 & 0,12 & 3,74 & 0 & 0,39 \\
$\begin{array}{c}\text { Atributos tangíveis do carro } \rightarrow \\
\quad \text { Julg. Passo a Passo }\end{array}$ & 0,35 & 0,05 & 7,25 & 0 & 0,5 \\
$\quad \begin{array}{c}\text { Seg. Pessoal } \rightarrow \text { Atributos } \\
\text { tangíveis do carro }\end{array}$ & 2,08 & 0,83 & 2,48 & 0,01 & 0,48 \\
$\begin{array}{c}\text { Hedonismo } \rightarrow \text { Julg. Afetivo } \\
\text { Poder sobre Recursos } \rightarrow\end{array}$ & 0,55 & 0,19 & 2,93 & 0 & 0,21 \\
$\quad 0,27$ & 0,09 & 2,98 & 0 & 0,29 \\
$\quad \begin{array}{c}\text { Julgamento Afetivo } \\
\text { Soder sobre Recursos } \rightarrow\end{array}$ & 0,9 & 0,09 & 10,03 & 0 & 0,64 \\
$\begin{array}{c}\text { Julg. Afetivo } \rightarrow \text { Significado Simbólico } \\
\quad \text { Simbólico }\end{array}$ & 0,38 & 0,07 & 5,37 & 0 & 0,38 \\
Idade $\rightarrow$ Segurança Pessoal & 0,05 & 0,02 & 2,1 & 0,03 & 0,2 \\
\hline
\end{tabular}

Fonte: Dados da pesquisa

A tabela 49 demonstra que as relações testadas são significativas. Poder de Domínio foi excluída da Tabela 49 por não apresentar correlação significativa no modelo estrutural 
com Significado Utilitário. Assim, Julgamento Passo a Passo prediz Significado Utilitário, Atributos tangíveis do carro prediz Julgamento Passo a Passo, o Valor Humano de Segurança Pessoal prediz Atributos tangíveis do carro, Hedonismo prediz Julgamento Afetivo acerca de automóveis, Poder sobre Recursos prediz Julgamento Afetivo e Significado Simbólico, sendo que seu poder de predição é mais expressivo em Significado Simbólico $(0,64)$.

No intuito de verificar possíveis problemas de ajuste, a covariância residual padronizada e os índices de modificação (M.I) foram averiguados. As variáveis SG12, SG1, SG5 e SG9 apresentaram altos índices de modificação com outras variáveis do modelo em diferentes construtos no modelo estrutural, os C.R foram abaixo de 1,96 e o p-valor superior a 0,05 , portanto, foram retiradas do modelo. O modelo estrutural para o Brasil que respeita o Modelo de duas Rotas (Allen, 1997) com as variáveis significativas é apresentado pela figura 18. 


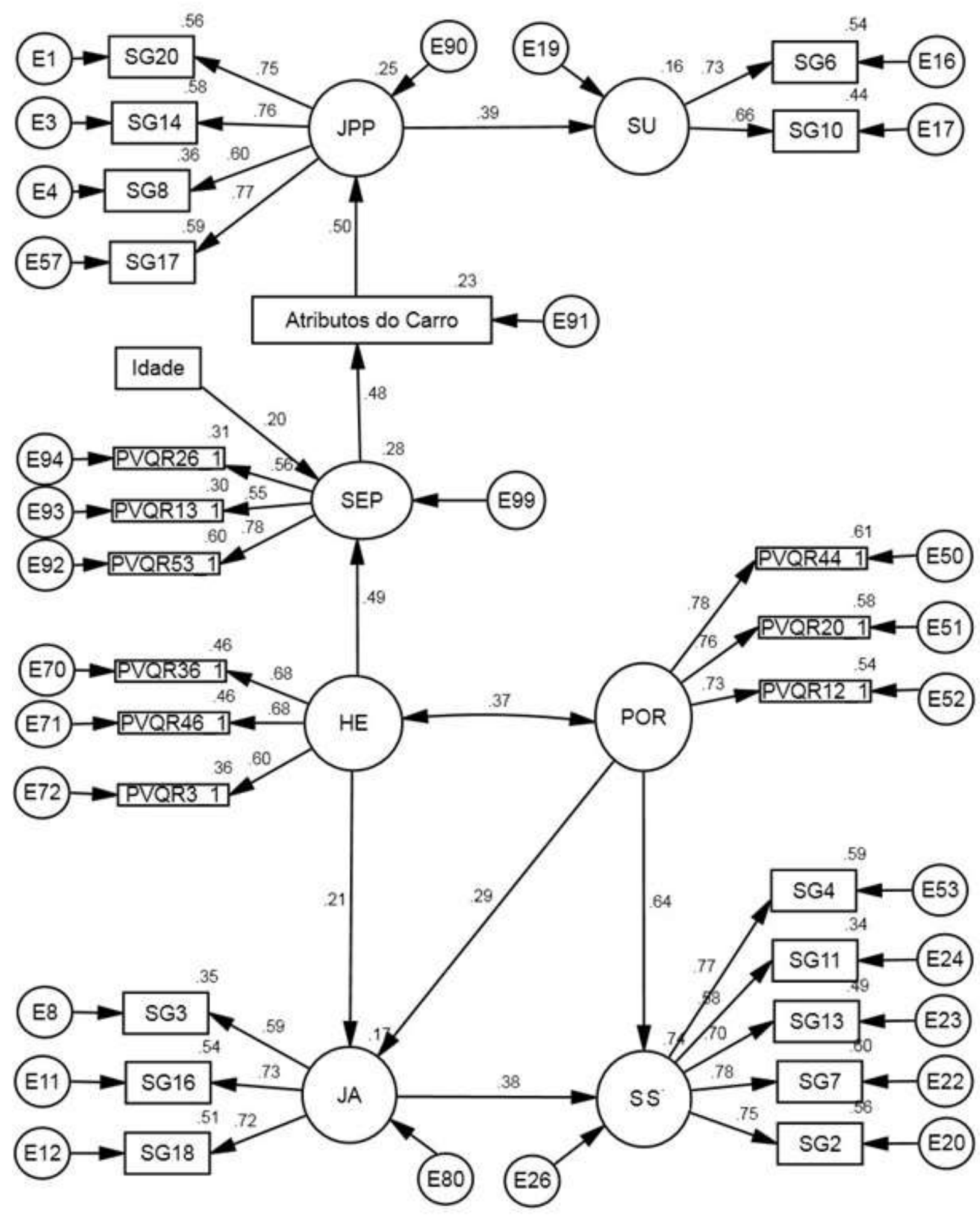

Figura 18. Modelo Estrutural Geral para o Brasil Fonte: Dados da pesquisa

$\mathrm{O}$ ajuste do modelo foi verificado e todos os índices apresentaram-se adequados uma vez que X2/G.L=1,76, CFI=0,92, RMSEA=0,05 e SRMR=0,08. Observando o $\mathrm{R}^{2}$ das variáveis latentes, $17 \%$ da variabilidade do Julgamento Afetivo para automóveis pode ser 
explicado por Hedonismo e Poder sobre Recursos, 74\% do Significado Simbólico para automóveis pode ser explicado pelo Valor Humano de Poder sobre Recursos e Julgamento Afetivo, 23\% da avaliação dos atributos tangíveis do carro pode ser explicado pelo Valor Humano de Segurança Pessoal e idade, de maneira indireta, 25\% do Julgamento Passo a Passo pode ser explicado pelos Atributos tangíveis do carro e 16\% do Significado Utilitário do automóvel pode ser explicado pelo Julgamento Passo a Passo.

O efeito direto de Segurança Pessoal sobre Julgamento Passo a Passo foi testado para observar se existia efeito direto de algum Valor Humano em Julgamento Passo a Passo no Brasil. Como sugere Allen (1997), os Valores Humanos medeiam a relação com os Atributos tangíveis do carro no Brasil. A figura 19 representa a relação entre as três variáveis de modo direto e indireto no Brasil.

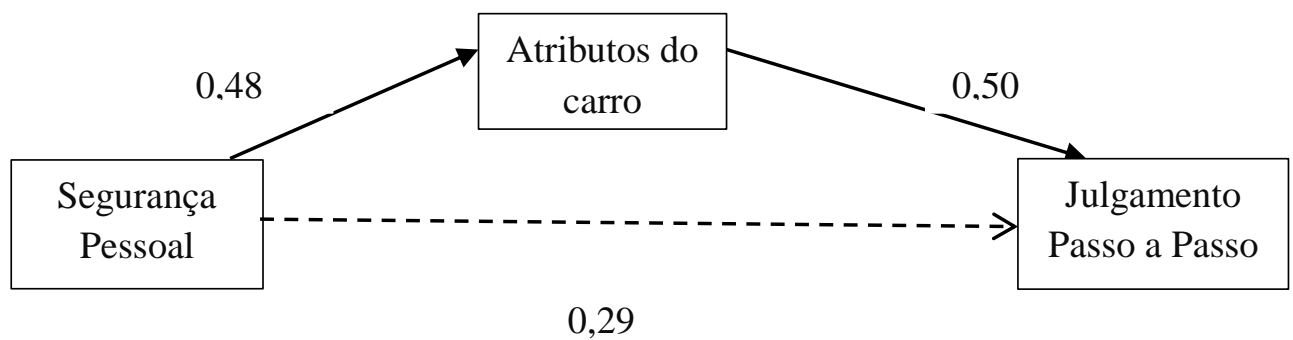

Figura19. Relação de Mediação de atributos tangíveis do carro entre Segurança Pessoal e Julgamento Passo a Passo no Brasil

Fonte: dados da pesquisa

Como apontado pelas regressões realizadas na subseção 7.4, o $\mathrm{R}^{2}$ entre Segurança Pessoal e Julgamento Passo a Passo, no Brasil, é 0,09 $(\mathrm{R}=0,30)$, enquanto entre Segurança Pessoal e Atributos tangíveis do carro, o $R^{2}=0,23(R=0,48)$ e Atributos tangíveis do carro e Julgamento Passo a Passo, o $\mathrm{R}^{2}=0,25(\mathrm{R}=0,50)$, indicando relação de mediação.

Considerando a amostra coletada nos Estados Unidos da América, as variáveis Idade e Atributos tangíveis do carro também foram inseridas no modelo; foram acrescentados os Valores Humanos que apresentaram correlações significativas, como apontados na subseção 7.4. No intuito de verificar possíveis problemas de ajuste, a covariância residual padronizada e os índices de modificação (M.I), foram averiguadas as variáveis SG1 e SG17 bem como as variáveis SG16 e SG3, que apresentaram índices de modificação acima de 15,0, como indica Marôco (2010), por ser o limite desejável dos índices de modificação; portanto, o modelo foi testado com as variáveis com erros correlacionados e sem as variáveis com menor índice de estimação entre elas. O X2/G.L do modelo com as variáveis com erros correlacionados 
resultou em 2,05 e o X2/G.L com as variáveis SG3 e SG1 excluídas apresentou $\mathrm{X} 2 / \mathrm{G} . \mathrm{L}=2,09$; portanto, foi mantido o modelo com os erros correlacionados.

O modelo de Duas Rotas (Allen, 1997) foi testado e suas relações e estimativas apresentadas conforme a tabela 50 .

Tabela 50

Estimativas do Modelo Estrutural nos Estados Unidos da América

\begin{tabular}{|c|c|c|c|c|c|}
\hline & Estimação & $\begin{array}{l}\text { Erro padronizado } \\
\text { (S.E.) }\end{array}$ & C.R. & P-valor & $\begin{array}{l}\text { Estimação da } \\
\text { regressão } \\
\text { padronizada }\end{array}$ \\
\hline $\begin{array}{c}\text { Julg. Passo a Passo } \rightarrow \\
\text { Sig. Utilit. }\end{array}$ & 0,46 & 0,12 & 3,74 & 0 & 0,39 \\
\hline $\begin{array}{l}\text { Atributos tangíveis do } \\
\text { carro } \rightarrow \text { Julg. Passo a } \\
\text { Passo }\end{array}$ & 0,35 & 0,05 & 7,25 & 0 & 0,5 \\
\hline $\begin{array}{l}\text { Seg. Pessoal } \rightarrow \text { Atributos } \\
\text { tangíveis do carro }\end{array}$ & 2,08 & 0,83 & 2,48 & 0,01 & 0,48 \\
\hline $\begin{array}{c}\text { Hedonismo } \rightarrow \text { Julg. } \\
\text { Afetivo }\end{array}$ & 0,55 & 0,19 & 2,93 & 0 & 0,21 \\
\hline $\begin{array}{c}\text { Poder sobre Recursos } \rightarrow \\
\text { Julgamento Afetivo }\end{array}$ & 0,27 & 0,09 & 2,98 & 0 & 0,29 \\
\hline $\begin{array}{c}\text { Poder sobre Recursos } \rightarrow \\
\text { Significado Simbólico }\end{array}$ & 0,9 & 0,09 & 10 & 0 & 0,64 \\
\hline $\begin{array}{c}\text { Julg. Afetivo } \rightarrow \\
\text { Significado Simbólico }\end{array}$ & 0,38 & 0,07 & 5,37 & 0 & 0,38 \\
\hline $\begin{array}{l}\text { Sig. Simbólico } \rightarrow \\
\text { Segurança Pessoal }\end{array}$ & 0,05 & 0,02 & 2,1 & 0,03 & 0,2 \\
\hline $\begin{array}{c}\text { Significado Simbólico } \rightarrow \\
\text { Idade }\end{array}$ & & & & & \\
\hline
\end{tabular}

A tabela 50 demonstra que as relações testadas são significativas. Os Valores Humanos de Poder de Domínio e Poder de Recursos não apresentaram P-valor significativo quando relacionados com Significado Simbólico e Significado Utilitário, respectivamente, e, portanto, foram excluídos do modelo. Assim, Julgamento Passo a Passo prediz Significado Utilitário, Atributos tangíveis do carro prediz Julgamento Passo a Passo, o Valor Humano de Segurança Pessoal prediz Atributos tangíveis do carro, Hedonismo prediz Julgamento Afetivo acerca de automóveis, Poder sobre Recursos prediz Julgamento Afetivo e Significado Simbólico, sendo que seu poder de predição é mais expressivo em Significado Simbólico $(0,75)$. A Figura 21 apresenta o modelo estrutural considerando o Modelo de Duas Rotas (Allen, 1997), os Valores Humanos presentes nas regressões na subseção 7.4, idade e atributos tangíveis do carro. 


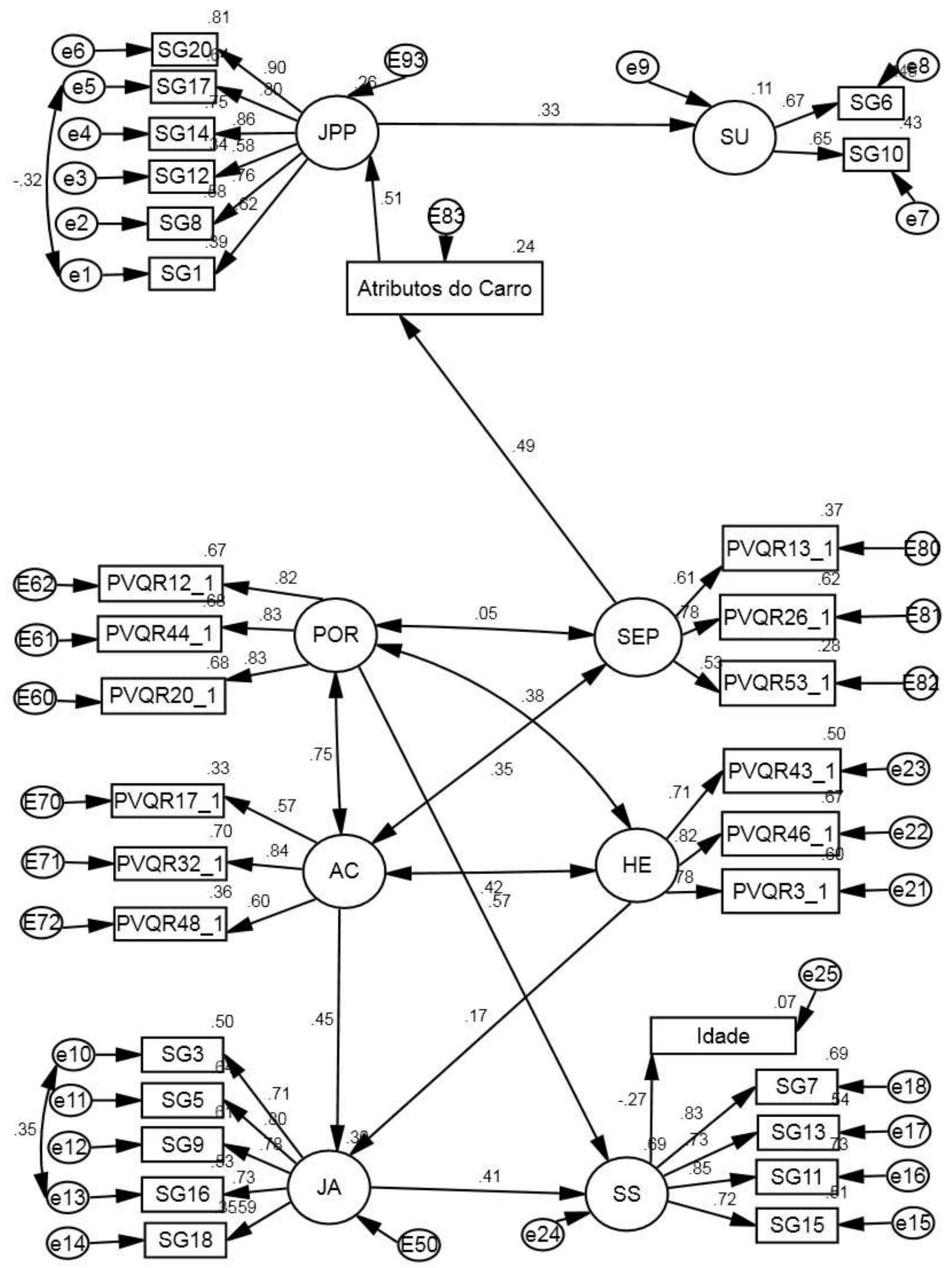

Figura 4. Modelo estrutural nos Estados Unidos da América 
Os índices do modelo apresentaram-se adequados, X2/G.L=2,05, CFI=0,90, RMSEA=0,05 e SRMR=0,08 indicando bons ajustes do modelo nos Estados Unidos da América, para Julgamento e Significado de automóveis preditos por Valores Humanos, respeitando o Modelo de Duas Rotas. Observando o $\mathrm{R}^{2}$ das variáveis latentes, $30 \%$ da variabilidade do Julgamento Afetivo para automóveis pode ser explicado por Hedonismo e Realização, 69\% do Significado Simbólico para automóveis pode ser explicado pelo Valor Humano de Poder sobre Recursos e Julgamento Afetivo, 24\% da avaliação dos atributos tangíveis do carro pode ser explicado pelo Valor Humano de Segurança Pessoal e idade de maneira indireta, 26\% do Julgamento Passo a Passo pode ser explicado pelos Atributos tangíveis do carro e $11 \%$ do Significado Utilitário do automóvel pode ser explicado pelo Julgamento Passo a Passo.

O efeito direto de Segurança Pessoal sobre Julgamento Passo a Passo foi testado para observar se existia efeito direto de algum Valor Humano em Julgamento Passo a Passo, nos Estados Unidos da América. Como sugere Allen (1997), os Valores Humanos medeiam a relação com os Atributos tangíveis do carro no Brasil. A figura 21 representa a relação entre as três variáveis de modo direto e indireto nos Estados Unidos da América.

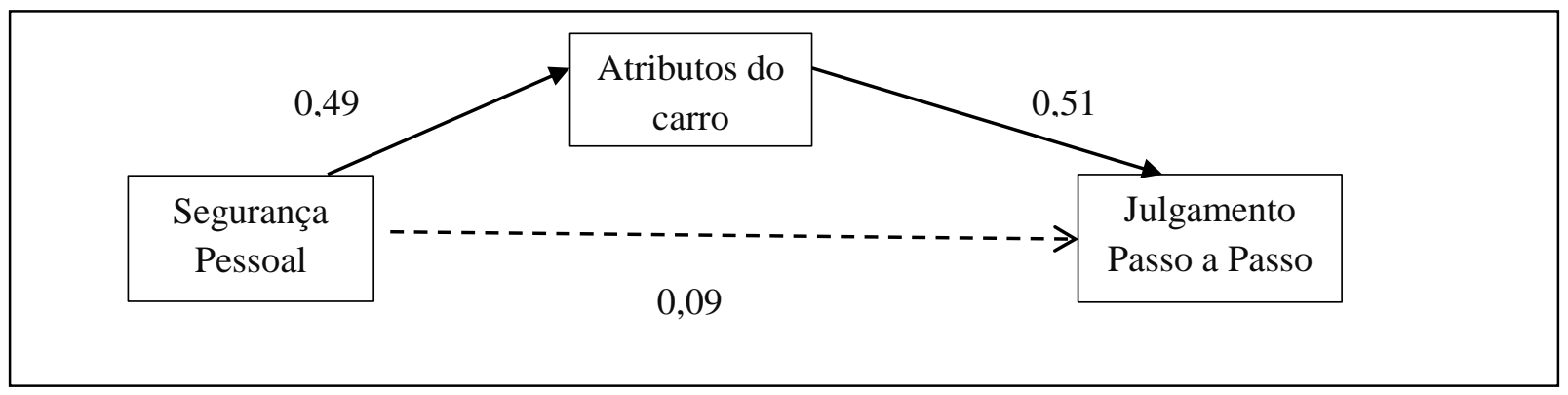

Figura 21. Relação de Mediação de atributos tangíveis do carro entre Segurança Pessoal e Julgamento Passo a Passo nos Estados Unidos da América

Fonte: Dados da pesquisa

Como apontado pelas regressões realizadas na subseção 7.4, o $\mathrm{R}^{2}$ entre Segurança Pessoal e Julgamento Passo a Passo no Brasil é 0,03 ( $R=0,09)$, enquanto Segurança Pessoal e Atributos tangíveis do carro o $\mathrm{R}^{2}=0,23(\mathrm{R}=0,49)$ e Atributos tangíveis do carro e Julgamento Passo a Passo o $\mathrm{R}^{2}=0,25(\mathrm{R}=0,51)$, indicando relação de mediação.

\subsection{Análise Multigrupo}

A Análise Multigrupo foi realizada considerando a amostra brasileira e estadunidense de modo conjunto, no intuito de observar se o Modelo de Duas Rotas se assemelhava, levando em consideração países diferentes. O modelo conjunto foi testado 
utilizando as estruturas empíricas no Brasil e nos Estados Unidos apresentadas na subseção 7.6. Em ambos os modelos, os ajustes foram insatisfatórios $\mathrm{X} 2 / \mathrm{G} . \mathrm{L}=8,40$, CFI=0,81, $\mathrm{RMSEA}=0,15$ e $\mathrm{SRMR}=0,15$ para o modelo conjunto utilizando a estrutura empírica no Brasil e X2/G.L=7,87, CFI=0,75, RMSEA=0,18 e SRMR=0,15 utilizando a estrutura empírica nos Estados Unidos da América, indicando que as estruturas são independentes para cada um dos países estudados.

\section{DISCUSSÃO}

Após a apresentação dos resultados, procedeu-se à comparação dos mesmos com as hipóteses de pesquisa com o objetivo de determinar se elas foram confirmadas ou rejeitadas pela pesquisa empírica. A tabela 51 apresenta as hipóteses de pesquisa e os respectivos resultados que serão discutidos na presente seção.

Tabela 51

Hipóteses e resultados

H1: O Julgamento Afetivo para compra de automóveis será predominantemente superior no Brasil comparativamente com os Estados Unidos da América.

Aceita

H2: O Julgamento Passo a Passo para compra de automóveis será predominantemente superior nos Estados Unidos da América comparativamente com o Brasil.

Aceita

H3: Os Valores Pessoais são capazes de predizer os tipos de Julgamento e Atribuição de Significado para automóveis no Brasil e nos Estados Unidos da América.

Aceita

H4: Os Valores Humanos são capazes de predizer os tipos de Julgamento e Atribuição de Significado para automóveis no Brasil e nos Estados Unidos da América

Aceita

H5: Valores Pessoais conjuntamente com Valores Humanos predizem melhor os tipos de Julgamento e Atribuição de Significado para automóveis do que separadamente no Brasil e nos Estados Unidos da América.

Rejeitada

H6: A idade influencia o modo como estadunidenses e brasileiros julgam automóveis.

Aceita

H7: O Modelo de pesquisa funciona de maneira semelhante no Brasil e Estados Unidos

Rejeitada Fonte: $\mathrm{O}$ autor. 
Assim, a presente etapa tem por finalidade analisar e interpretar os resultados encontrados. Para tanto, os achados serão confrontandos com a literatura indicada e os objetivos de pesquisa. Assim, primeiro serão discutidas as análises descritivas como média, mediana, valores máximos e mínimos, curtose e assimetria das variáveis para, então, proceder à dicussão dos testes de médias, regressões em bloco, regressões passo a passo, análises confirmatórias, modelagem por equações estruturais e, por fim, à análise multigrupo, confrontando Brasil e Estados Unidos da América, considerando os modelos elaborados na modelagem por equações estruturais.

Considerando as análises descritivas, era esperado tanto para Valores Pessoais quanto para Valores Humanos que os resultados apresentassem altas médias, visto que Schwartz (1992) argumenta que a estrutura de Valores é universal; sendo assim, nenhuma tipologia de valor deveria obter média próxima de zero, uma vez que todos os Valores estão presentes nos indivíduos, mudando apenas aqueles que são mais fortemente endossados. A moda, de maneira geral, reforçou essa lógica; a maioria dos Valores tanto Pessoais quanto Humanos também ficou próxima do máximo.

O fato de Julgamento Afetivo ser predominante para escolhas de automóveis no Brasil e o Julgamento Passo a Passo ser predominante nos Estados Unidos da América atende à literatura proposta para o tema. Estudos de Torres e Allen (2009) encontraram maior predominância desse tipo de julgamento para escolhas de automóveis quando comparados com a Austrália, atendendo também à proposição nesse mesmo estudo de que a cultura afeta o processo de julgamento dos produtos. Os Valores Humanos influenciam no processo de julgamento, sendo mais direto no Brasil e mais indireto nos Estados Unidos da América, atendendo e confirmando a hipótese 1 do presente de estudo de que o Julgamento Afetivo Afetivo para compra de automóveis será predominantemente superior no Brasil, comparativamente com os Estados Unidos da América, e a hipótese 2 de que o Julgamento Passo a Passo para a compra de automóveis será predominantemente superior nos Estados Unidos da América, comparativamente com o Brasil.

Quando correlacionados os tipos de julgamento e atribuição de significado com Valores Pessoais, os resultados obtidos respeitaram as proposições de Allen (2000) de que os Valores correlacionam-se mais fortemente com o Significado Simbólico do que com o Significado Utilitário. Os Valores Pessoais também correlacionaram-se mais fortemente com atributos do carro do que com o Significado Utilitário e este se correlacionou mais fortemente com atributos tangíveis do carro, sugerindo uma relação de mediação, como aponta Allen (2000), de que uma relação indireta ocorre entre Valores Humanos e Julgamento Passo a 
Passo por meio dos atributos do produto tanto para o Brasil quanto para os Estados Unidos da América. Isso significa que os Valores Humanos dos indivíduos afetam o modo como os indivíduos avaliam os atributos tangíveis do carro e implica em entendimento que para automóveis, quando elementos tangíveis são comunicados, divulgados ou enaltecidos, eles vão sofrer estimativas, que serão influenciadas pelos Valores Humanos dos indivíduos que estão avaliando aquele automóvel, assim, formando um julgamento indireto do produto.

Os Valores Pessoais apresentaram diversas correlações entre si, acima de 0,50, tanto para a amostra brasileira quanto para a amostra estadunidense, sugerindo multicolinearidade (Hair et al. 2009) entre os itens. Pasquali (2012) aponta que, quando os itens apresentam alta correlação entre si, é provável que existam fatores de segunda ordem ou até mesmo solução unifatorial. A escala LOV foi elaborada com base nos Valores Humanos, propostos por Rockeach (1973), porém, os itens refletem diretamente os Valores Terminais de Rockeach (1973), ou seja, cada item representa unicamente um Valor Humano. A própria natureza abstrata da estrutura de Valores Humanos e o fato de estudar-se quais são mais fortemente endossados em relação aos outros (Rockeach, 1973) e não quais Valores Humanos estão ou não presentes limita a adoção de uma escala simples com 9 itens abstratos como a LOV, aumentando a oportunidade de que o respondente simplesmente não consiga priorizar sua escolha claramente. Kahle e Kennedy (1998) propõem que uma escala com intervalos maiores (1 a 10) em detrimento de escalas do tipo likert, como as utilizadas por outros pesquisadores de Valores Humanos (Schwartz et al., 2012, Rokeach, 1973, Schwartz, 1992), atenua o efeito de pouca variância entre as respostas. Resultados encontrados nesse estudo sugerem que a utilização do intervalo de 1 a 10 proposto por Kahle e Kennedy (1988) não resultaram em uma variabilidade melhor do que a Escala PVQ-R que utiliza intervalo de 6 pontos.

A escala LOV apresentou médias altas, destacadas na tabela 20, para todos os Valores Pessoais no Brasil, inclusive a moda para todos os valores foi 9. No caso dos Estados Unidos da América, ainda que a maioria dos Valores Pessoais resultasse em moda de valor 10, ocorreu melhor variabilidade pois tanto as médias quanto medianas foram mais amplamente distribuidas. No entanto, a escala PVQ-R apresentou maior variabilidade em ambos os países. Isso implica em comparações mais adequadas entre os Valores Humanos coletados em cada país e os Valores Pessoais coletados nesses mesmos países, que permitem, assim, delinear satisfatoriamente as características culturais em função dos Valores Humanos das amostras coletadas. Isso significa também que, uma vez que ambas as escalas - de Valores Humanos e 
Valores Pessoais - se prestam a medir elementarmente a estrutura de Valores de um indivíduo, a escala de Valores Humanos discrimina melhor os Valores dos respondentes, pois não fica fortemente polarizada em resultados altos como a escala LOV de Valores Pessoais, que indica, inclusive, pela alta colinearidade entre os seus itens, que os itens têm baixa capacidade de disciminação entre eles.

Os maiores escores de médias encontrados na coleta utilizando Valores Pessoais foram divertir-se e aproveitar a vida e autorrealização, respectivamente, com 8,84 e 8,83 no Brasil, nos Estados Unidos da América os dois maiores valores encontrados foram de 7,44 para autorrealização e 7,46 para autorrespeito. Apesar de a escala LOV ser utilizada para os indivíduos e não para o país, nota-se diferença nos Valores Pessoais endossados pelos brasileiros em comparação com os estadunidenses. Isso indica que as amostras, quando comparadas em função dos Valores Pessoais, apresentam diferenças quanto aos Valores Pessoais com maior média, logo, mais fortemente endossados por cada país. Essa indicação sozinha sugere que as priorizações dos invíduos, em cada país, não são equivalentes, sugerindo diferenças culturais.

Considerando os Valores Humanos, os maiores escores de média encontrados para a amostra brasileira foram 5,12 e 5,28 para os tipos motivacionais de Benevolência Cuidado e Conformidade com Regras. A amostra estadunidense apresentou maiores escores para Autodireção de Pensamento e Benevolência Cuidado, com 4,97 e 4,80. A apresentação de escores de resultados agregados em relação a país, que utiliza Valores Humanos, é encontrada na literatura, valendo-se da escala Schwartz Value Survey, SVS, (Schwartz, 1992); no entanto, a escala PVQ-R permite a mesma análise, uma vez que pode ser empregada em mais de um nível de análise (Schwartz et al., 2012) e, por ser um refinamento da mesma estrutura básica de Valores Humanos encontrados nas escalas de Valores Humanos anteriores: o SVS (Schwartz, 1992) e o Portrait Values Questionnaire (Schwartz et al., 2001). Isso significa que, pela análise da média, as amostras possuem alguma semelhança quanto ao Valor Humano, mais fortemente endossado em ambos os países, uma vez que benevolência foi o mais fortemente endossado no Brasil e o segundo mais fortemente endossado nos Estados Unidos da América. Porém, é interessante destacar que os outros Valores Humanos que obtiveram médias altas no Brasil e nos Estados Unidos da América são opostos dentro da teoria de Valores Humanos (Schwartz et al., 2012), o que sugere que, ainda que um Valor Humano seja congruente, o outro aponta para uma forte diferenciação das amostras, implicando em diferenças culturais como apontado pelos resultados dos Valores Pessoais. 
Com relação à variável idade, foi observado que ocorreram baixíssimas correlações com as demais variáveis presentes na pesquisa, indicando pouca ou nenhuma linearidade entre idade e Valores Humanos, Valores Pessoais e Tipos de Julgamento e Atribuição de Significado. Stockard, Carpenter e Kahle (2014) sugeriram que estudos nos Estados Unidos da América com relação aos Valores Pessoais e idade não apresentaram relações lineares ou curvilineares expressivas, com correlações em torno de 0,20 para alguns Valores Pessoais; os autores sugerem que a estrutura de Valores sofre pouca mudança ao longo da vida. De maneira geral, esses resultados também foram encontrados em ambos os países para ambas as escalas de Valores, sendo que, no Brasil, a maior correlação encontrada foi de 0,20 com Segurança Pessoal. Isso indica que quanto mais velho for o indivíduo, maior será a sua preocupação com segurança pessoal; infere-se, assim, que tal ocorrência se deve ao contexto brasileiro de insegurança com relação à criminalidade.

Em se tratando das regressões em bloco, considerando todos os Valores como variáveis independentes conjuntamente utilizadas para observar a predição dos Valores Humanos e Valores Pessoais a respeito do Tipo de Julgamento e Atribuição de Significado, observou-se que a estrutura da relação entre Valores e Tipos de Julgamento e Atribuição de Significado foi respeitada em ambos os países. Segundo as proposições de Allen (2000), os Valores Humanos predizem mais fortemente o Julgamento Afetivo e o Significado Simbólico do que o Julgamento Passo a Passo e o Significado Utilitário, sendo esses preditos, de forma indireta, utilizando os Valores Humanos por intermédio dos atributos do produto, confirmando a hipótese 3 de que os Valores Humanos são capazes de predizer os tipos de Julgamento e Atribuição de Significado para automóveis no Brasil e nos Estados Unidos da América.

A proposta de Allen (2000) para as rotas de julgamento utiliza somente Valores Humanos. No entanto, observa-se nesse estudo que os Valores Pessoais também apresentaram a mesma estrutura em ambos os países, predizendo mais fortemente $o$ Julgamento Afetivo e o Significado Simbólico do que o Julgamento Passo a Passo e o Significado Utilitário, sendo que estes dois últimos foram mais fortemente preditos por Valores Pessoais, que possuem atributos do produto como mediador. Ainda que com escores inferiores aos Valores Humanos, os Valores Pessoais foram capazes de predizer os tipos de julgamento e a atribuição de significado no Brasil e nos Estados Unidos da América, assim confirmando a hipótese 4 do estudo de que os Valores Pessoais são capazes de predizer os tipos de Julgamento e Atribuição de Significado para automóveis no Brasil e nos Estados Unidos da América, o que implica, em termos científicos, que a estrutura de Valores proposta 
por Kennedy e Kahle (1986) interage dentro do modelo de Duas Rotas, de Allen (2000), de forma semelhante, uma vez que o modelo originalmente elaborado com a estrutura proposta por Schwartz (1992) também funciona com a escala refinada, elaborada por Schwaztz et al, (2012) e a escala LOV, de Kennedy e Kahle (1986), reforçando que os Valores em diversas escalas atuam, de forma indireta, no Julgamento Passo a Passo e, de forma direta, no Julgamento Afetivo, conferindo mais robustez ao modelo de Duas Rotas.

Foram realizadas regressões que respeitam as considerações de Field (2009) para observar a capacidade de predição dos Tipos de Julgamento e Atribuição de Significado pelos Valores Humanos e Valores Pessoais de modo conjunto. A hipótese estudada, de acordo com a literatura, e a dos Valores Humanos ou Pessoais, que tratam da mesma estrutura psicológica, representam elementarmente as mesmas características psicológicas dos indivíduos. Os resultados encontrados corroboram essa hipótese, pois Julgamento Afetivo, Julgamento Passo a Passo, Significado Simbólico e Significado Simbólico tanto no Brasil quanto nos Estados Unidos da América não apresentaram predições mais elevadas quando calculados utilizando Valores Humanos e Valores Pessoais conjuntamente, refutando a hipótese 5 desse estudo de que os Valores Pessoais juntamente aos Valores Humanos predizem melhor os tipos de Julgamento e Atribuição de Significado para automóveis do que separadamente, no Brasil e nos Estados Unidos da América. Isso implica que, por se referirem a construtos semelhantes, não se justifica unir as escalas para calcular qualquer um dos tipos de julgamento ou atribuição de significado pois conjuntamente o poder de predição não aumentou.

No entanto, observou-se que para as todas as dimensões de Tipos de Julgamento e Atribuição de Significado, tanto no Brasil quanto nos Estados Unidos, os Valores Humanos atingiram uma predição superior à de Valores Pessoais. Quando observados de modo conjunto, ou seja, Valores Humanos e Valores Pessoais predizendo os tipos de Julgamento e Atribuição de significado, os escores não ultrapassaram os escores atingidos por Valores Humanos somente. Por se tratar de uma estrutura psicológica que elementarmente é equivalente e pelos resultados em conjunto encontrados serem iguais aos resultados de Valores Humanos, somente argumenta-se que os Valores Humanos apresentam uma estrutura que engloba os Valores Pessoais.

A literatura proposta reforça essa proposição, uma vez que a estrutura de Valores Pessoais foi desenvolvida com base na estrutura, proposta por Rockeach (1973), levando em consideração 9 Valores básicos centrais do ser humano, enquanto a estrutura proposta por Schwartz et al. (2012), apesar de utilizar também a estrutura básica em Rockeach (1973), 
utiliza os Valores Humanos de maneira mais discriminada com 19 tipos motivacionais que, teoricamente, engloba a de Kennedy e Kahle (1986). Portanto, recomenda-se utilizar a estrutura de Valores Humanos desenvolvida por Schwartz et al. (2012), pois ela foi capaz de predizer mais fortemente os Tipos de Julgamento e Atribuição de Significado; no entanto, a escala de Schwartz el at. (2012) possui 57 itens enquanto a escala LOV possui 9 itens. Caso seja necessário utilizar uma escala mais parcimoniosa, apesar da perda de explicação de variância, a escala LOV é capaz de atender aos objetivos do pesquisador que tenha como objetivo verificar a influência dos Valores Pessoais nos tipos de Julgamento e Atribuição de Significado.

Estudos anteriores, de Torres e Allen (2009), verificaram a relação entre Valores Humanos e Tipos de Julgamento e Atribuição de Significado no Brasil para Automóveis e constataram a existência da relação entre os construtos; porém, a escala utilizada foi a Portrait Values Questionnaire (PVQ) e a verificação foi realizada com osValores Humanos de modo conjunto, em bloco. No presente trabalho, os Tipos de Julgamento e Atribuição de Significado foram estudados frente aos Valores Humanos de modo isolado, ou seja, foi verificada a capacidade de cada tipo motivacional, de modo isolado, predizer Julgamento Afetivo, Julgamento Passo a Passo, Significado Simbólico e Significado Utilitário. Observando a relação entre Valores Humanos e Tipos de Atribuição e Significado nos Estados Unidos da América, Julgamento Afetivo foi predito por Realização e Hedonismo enquanto Julgamento Passo a Passo foi predito por Segurança Pessoal. O Significado Simbólico foi predito por Poder sobre Recursos e Poder de Domínio enquanto Significado Utilitário foi predito por Poder Sobre Recursos. Observa-se uma estrutura de predição semelhante, porém não equivalente. Estudos de Torres e Allen (2009) sugerem que a cultura pode influenciar o modo como as pessoas julgam produtos e realizam avaliações sobre o mesmo, indicando que as diferenças culturais entre Brasil e Estados Unidos da América podem influenciar a estrutura de quais Valores Humanos correlacionam-se com cada Tipo de Julgamento e Atribuição de Significado para automóveis em cada país.

Em decorrência de os Valores Humanos apresentarem escores superiores aos Valores Pessoais para a predição dos Tipos de Julgamento e Atribuição de Significado e Valores Humanos conjuntamente com Valores Pessoais apresentarem os mesmos escores que Valores Humanos isoladamente, foram realizadas regressões passo a passo seguindo as sugestões de Field (2009) somente com Valores Humanos, para identificar quais Valores Humanos são capazes de predizer os tipos de Julgamento e Atribuição de Significado no Brasil e nos Estados Unidos da América. 
Com relação ao Julgamento Afetivo no Brasil, os tipos motivacionais de Hedonismo e Poder sobre Recursos foram os capazes de melhor predizer, entre os 19 tipos motivacionais de Schwartz (2012). Hedonismo refere-se a prazer pessoal e Julgamento Afetivo está relacionado ao julgamento holístico baseado na autoimagem do invíduo (Allen, 2000); assim, o Julgamento Afetivo tem importância autoexpressiva, gerando prazer e, por consequência, ligado ao tipo motivacional de Hedonismo.

Julgamento Passo a Passo correlacionou-se positivamente com o tipo motivacional de Segurança Pessoal. No contexto de avaliação de automóveis, supõe-se que o processamento dos itens de segurança seja uma tarefa realizada cognitivamente, ativando o julgamento passo passo, sendo cada item de segurança avaliado separadamente.

Significado Simbólico foi o construto mais bem predito entre os Tipos de Julgamento e Atribuição de Significado, sendo predito por Poder sobre Recursos. Supõe-se nessa relação que o simbolismo de possuir um item que requer alto esforço financeiro, portanto, estando relacionado com Poder Sobre Recursos, cuja definição, segundo Schwartz et al. (2012, p.7) é "Poder pelo controle sobre materiais e recursos sociais", sendo a representatividade do automóvel simbólica quanto à aquisição de um bem que gera status social e sugere sucesso financeiro.

Foi efetivada, então, a análise fatorial confirmatória seguindo as considerações de Marôco (2009) e Byrne (2010) dos itens que compuseram a escalada de Julgamento e Significado como pré-requisito para a organização de um modelo estrutural juntamente com Valores Humanos. Para a análise fatorial confirmatória, no Brasil, os índices apresentam-se aceitáveis, todas as variáveis demonstraram ser signficativas, porém, a variável SG19 foi retirada do modelo como recomenda Marôco (2010) pois obteve-se nos resultados uma alta correlação com os termos de erro de outras variáveis da mesma dimensão. A variável SG19 refere-se à dimensão "Significado Utilitário", composta por somente 3 itens; a retirada de um item deixou o fator com a quantidade mínima de itens, como proposta por Byrne (2010), para uma análise confirmatória e uma posterior modelagem estrutural. O mesmo item (SG19) apresentou problemas por não ser significativo na regressão para a amostra dos Estados Unidos da América, o que sugere que o item pode demandar reformulação ou mesmo exclusão. Devido ao construto ser composto por três itens somente, o que limita sua aplicação em contextos que outros itens desse construto sejam mal interpretados, acredita-se que a reformulação seja o mais indicado.

Como o construto representa Significado Utilitário, a revisão da definição do construto, seguindo os passos de Pasquali (2010), é indicada para se operacionalizar o 
construto por meio do item. Outra recomendação é operacionalizar o construto utilizando a TRI (Teoria da Resposta ao Item). Pasquali (2009) sugere que, ao contrário do praticado na Teoria Clássica dos Itens, onde se espera que os itens sejam correlacionados e reflitam o construto na Teoria da Resposta ao Item, um item é capaz de refletir o construto em questão; assim, baseando-se nos processos cognitivos estimulados na interpretação do Significado Utilitário, um novo item pode ser recomendado. Em último caso, a exclusão do item não inviabiliza a realização da análise confirmatória, porém deixa questionável a variância explicada do construto em questão com somente 2 itens.

Com relação à análise confirmatória para Significado e Julgamento realizada nos Estados Unidos da América, inicialmente, a análise com todos os itens originais da escala apresentou índices insatisfatórios, demandando ajustes, conforme recomenda Marôco (2010), SG19 e SG2 foram retirados do modelo por possuírem, respectivamente, p-valor acima de 0,05 e índice de modificação acima de 30,0. Após a retirada das variáveis, os índices da análise fatorial confirmatória apresentaram-se satisfatórios. Portanto, considerou-se recomendável a exclusão das variáveis SG19 e SG2. No caso da variável SG19, pertencente ao construto Significado Utilitário observa-se que, em ambos os países, sua compreenção indica ser problemática. Devido à baixa quantidade de itens que compõem o construto, as recomendações de reformulação são as mesmas utilizadas no modelo brasileiro.

No caso da variável SG2, uma vez que esta se refere à dimensão de Significado Simbólico, composta originalmente por seis itens, considerou-se no caso da amostra estadunidense que a retirada não afeta negativamente a realização da análise fatorial confirmatória tampouco a modelagem por equações estruturais; pelo contrário, foi a variável que apresentou menor estimação de regressão padronizada entre todas as variáveis da dimensão de Significado simbólico $(0,39)$; valores baixos de estimação da regressão padronizada afetam diretamente o valor do Rhô de Jöreskog, diminuindo a confiabilidade do item (Marôco, 2010). Assim, recomenda-se retirar a variável SG2 por critério de parcimônia da escala,baixa capacidade de predizer a variância do construto e comunalidade com outros construtos da mesma escala. A retirada das variáveis do modelo veio a ser pela melhora dos resultados dos índices gerais de ajuste da análise fatorial confirmatória.

Semelhante ao que foi observado nos Resultados, as correlações quadráticas entre os fatores apresentaram-se iguais ou inferiores em todos os fatores da amostra brasileira. $\mathrm{O}$ Significado Utilitário apresentou variância média extraída (VME) equivalente à sua correlação quadrática com Julgamento Afetivo porém, pelo fato de não ser superior e os conceitos não possuírem correlação teórica, optou-se por considerar que existia validade 
discriminante entre eles. Juntos, esses resultados significam que existe independência dos construtos; assim, Julgamento Afetivo, Julgamento Passo a Passo, Significado Simbólico e Significado Utilitário são construtos diferentes.

Considerando a amostra estadunidense, os valores do Rhô de Jöreskog apresentaramse superiores aos da amostra brasileira. Portanto, considerou-se que os itens possuíam confiabilidade convergente, e as correlações quadráticas dos fatores apresentam-se inferiores à VME, sugerindo que existe validade discriminante, que reforça os resultados encontrados na amostra brasileira de que os construtos são independentes e diferentes. Os valores obtidos, que utilizam a amostra estadunidense, foram superiores aos resultados retornados pela análise da amostra brasileira; ainda que a amostra brasileira possua índices aceitáveis, é possível que os índices obtidos se devam pelo viés da amostra brasileira, coletada majoritariamente com estudantes universitários, enquanto a amostra estadunidense foi coletada por intermédio da plataforma mechanical turk. Estudos anteriores (Buhrmester, Kwang \& Goslin, 2011; Paolacci, Chandler \& Ipeirotis, 2010) apontaram que as amostras obtidas pelo Mturk (mechanical turk) são mais diversas e melhores que as amostras de universitários, sendo consideradas superiores em variabilidade e representatividade; portanto, indicam melhor representatividade do fenômeno e refletem melhores ajustes para os fatores calculados empiricamente. Assim, recomenda-se a outros pesquisadores que utilizem a plataforma de coleta de dados Mturk quando possuírem em sua agenda de pesquisa respondentes (para suas questões de pesquisa) que sejam residentes dos Estados Unidos da América, uma vez que a operacionaliação da coleta é válida e elimina diversas barreiras físicas como distância, localização da amostra e custo de tempo.

Os tipos motivacionais presentes na predição dos Tipos de Julgamento e Atribuição de Significado na amostra brasileira foram Segurança Pessoal, Hedonismo e Poder Sobre Recursos. Para os três tipos motivacionais as respectivas variáveis observadas que os compõem apresentaram p-valor significativo, indicando que a estrutura original se manteve. Com relação à validade convergente, o rhô de Jöreskog referente aos três Valores Humanos apresentou valores acima de 0,50 (Marôco, 2010), indicando que a validade convergente e a variânca média extraída (VME) de todos apresentou valores superiores à sua correlação quadrática com os outros fatores que também indicam validade discriminante, sendo, portanto, congruente com a proposta teórica de Schwartz et al. (2012) referente à teoria refinada de Valores Humanos. Isso representa que para os tipos motivacionais presentes no modelo de pesquisa a estrutura foi igual à da escala original e à escala traduzida por Torres, 
Schwartz e Nascimento (2014), indicando robustez de a capacidade da escala refletir os construtos em diferentes países.

Considerando a amostra estadunidense, quatro tipos motivacionais foram capazes de predizer os Tipos de Julgamento e Atribuição de Significado; foram eles Segurança Pessoal, Hedonismo, Poder Sobre Recursos e Realização. Observa-se que os mesmos tipos motivacionais presentes na amostra coletada no Brasil também estão presentes na análise para os Estados Unidos da América, acrescidos do tipo motivacional Realização. Tal estrutura semelhante indica que os construtos ativados no julgamento e atribuição de significado de automóveis são semelhantes, porém a influência cultural pode estimular que outros construtos também sejam ativados no mesmo processo.

Hofstede (1980, 1983, 1984, 1991) demonstra que pessoas de diferentes grupos culturais realizam atribuições de maneiras diferentes, suas intenções e objetivos podem ser diferentes e, portanto, podem comportar-se de maneira diferente. Ainda que as proposições de Hofstede (1980) se refiram ao nível cultural de análise e no presente trabalho o nível seja individual, uma estrutura exatamente igual não era esperada de modo teórico, uma vez que, considerando um enfoque multinível de análise, presume-se que o nivel superior e a cultura gerem impacto no nível inferior - o indivíduo (Puente-Palacios \& Laros, 2009).

Os índices da amostra estadunidense também foram superiores à amostra brasileira. Atribuiu-se essa discrepância também à diversidade maior da amostra estadunidense, uma vez que a coleta foi realizada pelo website Mturk e os resultados obtidos possuíram distribuição mais aleatória, posto que advinham de vários estados diferentes dos Estados Unidos da América, com maior amplitude em distribuição de renda e outras variáveis demográficas, enquanto os dados, no Brasil, foram coletados presencialmente em Brasília. Os itens que compuseram os quatro tipos motivacionais presentes no modelo estadunidense adaptaram-se, conforme a teoria de Scwhartz et al. (2012), em razão de todos possuírem pvalor significativo na regressão com a variável latente representativa daquele respectivo tipo motivacional, os índices de ajuste foram satisfatórios; como o menor rhô de Jöreskog foi de 0,61 considera-se também que ocorre a validade convergente e todas as VME dos fatores foram superiores às correlação quadráticas com os outros fatores presentes, assim confirmando a validade discriminante. Isso aponta para indicação de robustez da escala original de Schwartz et al. (2012), visto que a proposta teórica da composição dos construtos com seus itens foi replicada. 
Considerando os modelos estruturais organizados com a amostra brasileira e estadunidense, devido à estrutura preditiva dos Valores Humanos frente à atribuição de significado, conforme estudado por Allen (1997), Allen (2000), Torres e Allen (2009), foram realizadas regressões passo a passo para identificar, entre os dezenove tipos motivacionais apresentados por Schwartz et al. (2012), quais possuíam maior poder preditivo, considerando como variáveis dependentes os Tipos de Julgamento e Atribuição de Significado. O modelo estrutural foi montado baseando-se teoricamente no Modelo de Duas Rotas (Allen, 1997) e, empiricamente, de acordo com quais tipos motivacionais apresentassem poder preditivo significativo.

Uma vez que existe suporte teórico para correlacionar Valores Humanos e Tipos de Julgamento e Atribuição de Significado, buscou-se examinar pontualmente quais tipos motivacionais estavam correlacionados com cada tipo de julgamento e atribuição de significado. Foram inseridos portanto no modelo brasileiro Segurança Pessoal, Hedonismo e Poder Sobre Recursos. Considerando o tipo motivacional Hedonismo, observou-se uma capacidade de predizer o Julgamento Afetivo para automóveis e também uma alta correlação com Segurança Pessoal. No que diz respeito à sua correlação com Julgamento Afetivo, a definição de Hedonismo por Schwartz et al. (2012, p.7) é "Gratificação de prazer e sensação", enquanto Allen (2001) descreve Julgamento Afetivo como um julgamento influenciado pelo autoconceito, focado no próprio indivíduo e não nas características físicas do objeto e sua capacidade de expressar esse autoconceito do indivíduo. Observa-se a proximidade teórica entre os construtos, que permite, assim, uma inferência de que para julgamento de automóveis, em teoria, Hedonismo influencia o Julgamento Afetivo, visto que Sirgy (1982) aponta que a autoexpressão do autoconceito de um indivíduo possui características hedônicas, ou seja, são construtos que teoricamente enaltecem processos cognitivos semelhantes.

A correlação teórica com Segurança Pessoal não é suportada por Schwartz et al. (2012), uma vez que a definição de Segurança Pessoal é "Segurança do indivíduo em seu ambiente imediato" (Schwartz et al. (2012, p. 7) e a definição não reflete aspectos emotivos ou internos e, sim, externos ou físicos. Isso significa que essa relação não era esperada com Julgamento Afetivo e ela não ocorreu, estando condizente com a definição dos construtos e os resultados estatísticos. Analisando o tipo motivacional Poder Sobre Recursos, este apresentou correlação com Hedonismo e Significado Simbólico. É necessário destacar que a maior correlação entre todos os tipos motivacionais e Tipos de Julgamento e Atribuição de Significado foi Poder Sobre Recursos frente a Significado Simbólico. De acordo com 
Schwartz et al. (2012, p.7) Poder Sobre Recursos é descrito como "Poder sobre controle de recursos materiais e sociais" enquanto Significado Simbólico é apresentado por Allen (2001) como a percepção subjetiva que um indivíduo alcança por intermédio das associações simbólicas dos atributos de um produto. A justificativa teórica para a associação dos contrutos perpassa pela definição de Bourdieu e Passeron (1979), que argumentam que as características de um produto manifestam as preferências e o gosto de quem os possui, acarretando em diferenças de classe e grupo, não só pela capacidade de possuir o item mas também pela sua representatividade como elemento subjetivo de semelhança entre grupos. Considera-se, assim, que existe correlação teórica entre Poder Sobre Recursos e Significado Simbólico para Automóveis. A correlação entre Hedonismo e Poder Sobre Recursos é justificada pela proximidade dos tipos motivacionais quando apresentados por Schwartz et al. (2012) em seu continuum de tipos motivacionais. Nesse mesmo continuum de tipos motivacionais, Schwartz et al. (2012) apontam que a estrutura de valores se organiza de modo contínuo, ou seja, os Valores Humanos são próximos aos seus vizinhos nesse contínuo e contrários àqueles opostos dentro da estrutura circular.

Considerando Segurança Pessoal, este foi capaz de predizer Julgamento Passo a Passo. Porém, seguindo os pressupostos teóricos de Allen (1997), sua predição é mediada pelos atributos do produto, no caso da presente pesquisa os atributos do automóvel; foi realizada uma regressão para averiguar essa proposição e, em ambos os países, a relação entre o tipo motivacional de Segurança Pessoal e os atributos do automóvel foi mais forte do que a relação direta entre Segurança Pessoal e Julgamento Passo a Passo, assim atendendo à indicação teórica. Uma vez que Segurança Pessoal é apresentada por Schwartz et al. (2012 p.7) como "Segurança do indivíduo no ambiente", Julgamento Passo a passo é definido por Allen (2001) como racional e realizado atributo por atributo, baseado na avaliação das características tangíveis e funções utilizáveis de um produto. Observa-se aqui a forte indicação de relação, uma vez que, dentro do processo de avaliação do automóvel, os atributos tangíveis do veículo, como são descritos pelos itens, representam itens de segurança do automóvel, ou seja, supõe-se que haja necessidade de processos cognitivos, a fim de confrontar o que representa tal item frente à avaliação do consumior e que essa avaliação seja realizada de forma racional.

Argumenta-se, portanto, que existe proximidade entre essa relação do tipo motivacional Segurança Pessoal com Julgamento Passo a Passo mediada por atributos do veículo, uma vez que de modo analítico as características do veículo são pesadas de forma racional, levando em consideração elementos físicos que são atribuidos aos automóveis como 
itens de segurança, proteção, facilidade de direção e outros atributos que compõem um automóvel. Assim, Segurança Pessoal influenciaria o modo como os indivíduos pesam essas características físicas ou funções práticas do automóvel. Significado Utilitário, apesar de apresentar predição baixa pelo tipo motivacional Poder de Domínio no Brasil e Poder de Recursos nos Estados Unidos da América, não compôs o modelo estrutural, pois em sua montagem os índices das regressões apresentaram resultados não significativos. Nos pressupostos teóricos do modelo de Duas Rotas, essa relação também não é indicada; portanto, a exclusão da relação entre os tipos motivacionais, que foram apresentados na regressão, e Significado Utilitário ocorreu por questões teóricas e empíricas no modelo estrutural.

Considerando a variável idade, no modelo para a amostra brasileira, não ocorreu predição significativa nas regressões passo a passo realizadas; portanto, recorreu-se à tabela de correlações apresentadas no subtópico 7.1 para testar a hipótese de que a idade influencia o modo como os brasileiros julgam automóveis. No modelo estrutural idade apresentou correlação significativa com o tipo motivacional Segurança Pessoal; assim, a variável idade foi incluída no modelo, porém o poder de predição foi de somente 4\%. Schwartz (1992) argumenta que o tipo motivacional de segurança é o segundo mais correlacionado com idade, perdendo somente para Poder. Kahle (1983) argumenta que a estrutura de Valores é muito pouco mutável ao longo da vida. Em face das proposições opostas, da não ocorrência da idade nas regressões passo a passo e do pouco poder preditivo no modelo, optou-se por rejeitar a hipótese 6 de que a idade influencia o modo como brasileiros julgam automóveis.

Para a amostra estadunidense a variável idade também foi inserida com base na matriz de correlações entre as variáveis, uma vez que não apresentou poder preditivo nas regressões passo a passo. Observa-se no modelo estadunidense a capacidade de Significado Simbólico predizer a idade; assim, quanto maior o Significado Simbólico do carro para o indivíduo menor sua idade. Nesse caso também se rejeita a hipótese 7 de que idade pode predizer tipos de julgamento ou atribuição de significado nos Estados Unidos da América, uma vez que a relação se estabeleceu na capacidade preditiva do Significado Simbólico em relação a idade. A justificativa teórica para tal relação apoia-se na presença do tipo motivacional de Realização no modelo estadunidense, sendo descrita por Schwartz et al. (2012, p.7) como "Sucesso de acordo com padrões sociais", representando simbolicamente o automóvel como atributo de conquista para o jovem estadunidense.

A hipótese 8 de que o modelo de Duas Rotas funciona de maneira semelhante no Brasil e Estados Unidos da América não foi suportada, uma vez que foram encontrados tipos 
motivacionais que, discriminadamente, correlacionaram-se diretamente com Julgamento Afetivo. Tal constatação empírica encontra suporte nos trabalhos de Torres, Schwartz e Nascimento (2014), que testam e confirmam a relação dos Valores Humanos com comportamentos diretos, permitindo um entendimento da teoria refinada de Valores Humanos como menos distante psicologicamente do fenômeno em por descrevem, mais especificamente, o comportamento do indivíduo. A própria estrutura teórica dos Valores Humanos apresentada por Schwartz (1992) apontava baixa relação com comportamenos propriamente ditos. A definição de Kluckhohn (1951) de que são guias para os comportamentos das pessoas reforça seu caráter genérico e pouco específico.

Argumenta-se, portanto, que a utilização de dezenove tipos motivacionais preditivos tem melhor capacidade de se correlacionar com Julgamento Afetivo, permitindo uma aproximação dos Valores Humanos quanto aos tipos de julgamento e atribuição de significado, destoante da proposta por Allen (1997), ainda que essa proposta de Allen (1997) tenha encontrado amparo parcial no modelo com a teoria refinada de valores, ou seja, ocorreu maior predição por meio do Significado Simbólico, e o Tipo Motivacional de Segurança Pessoal correlacionou-se com Julgamento Passo Passo mediado pelos Atributos do Veículo; porém, os índices de ajuste de ambos os modelos relacionaram Julgamento Afetivo predizendo Significado Simbólico e Julgamento Passo a Passo predizendo Significado Utilitário, sendo essa relação uma inversão do Modelo de Duas Rotas. Além disso, a influência de Hedonismo frente ao Julgamento Afetivo no Brasil e Hedonismo e Realização frente ao Julgamento Afetivo nos Estados Unidos da América não ocorrem no Modelo de Duas Rotas, sendo assim considerado uma modificação da abordagem do Modelo, propondo que, no caso estudado, para automóveis os Valores Humanos podem influenciar diretamente tanto o Julgamento Afetivo frente ao automóvel quanto o Significado Simbólico deste para o indivíduo, em ambos os países estudados.

Por fim, os modelos como um todo apresentaram relações amparadas pela literatura e índices satisfatórios; idade foi mantida no modelo para atender as hipóteses de pesquisa; porém, a remoção da idade do modelo é recomendada, uma vez que foi realizado o teste sem a presença de idade em ambos os modelos e ocorreu a melhora periférica nos índices gerais de ajuste de ambos os modelos. O teste com a remoção da idade não foi relatado nos resultados, uma vez que se buscou atender ao objetivo geral da pesquisa; no entanto, salientase que foi realizado o simples teste do modelo sem a variável idade. Considera-se que a estrutura de relação entre os Valores Humanos e os Tipo de Julgamento e Atribuição de Significado para automóveis é semelhante no Brasil e Nos Estados Unidos da América porém 
não equivalente, devido à presença do Tipo Motivacional de Realização no modelo estadunidense.

Foi realizada análise multigrupo, conforme recomendação de Marôco (2010), para verificar se os modelos possuíam variação entre si. Apesar da presença do tipo motivacional de Realização no modelo estadunidense, foram testadas as estruturas sem esse tipo motivacional, ou seja, considerando somente os tipos motivacionais que apresentaram poder de predição, ao mesmo tempo, em ambos os países. Além disso, também foi testada a estrutura brasileira e estadunidense utilizando as amostras de modo conjunto. Os resultados apontaram para uma diferença entre os modelos, que indicam estruturas independentes.Tal resultado é suportado pelos argumentos de Torres e Allen (2009) e Arnould, Prince e Zinkhan (2004) que argumentam que a cultura pode influenciar o modo como as pessoas consomem produtos, sugerindo que o consumo é influenciado pela necessidade de o indivíduo reforçar sua cultura. Considerando os resultados desse estudo, as médias de valores para Julgamento Passo a Passo e Julgamento Afetivo bem como as médias dos tipos motivacionais indicavam essa diferença tanto na predominância dos tipos de julgamento utilizados na compra de automóvel quanto na priorização dos tipos motivacionais dos brasileiros e dos estadunidenses.

A semelhança das estruturas indica, portanto, uma relação entre Valores Humanos e Tipos de Julgamento e Atribuição de Significado semelhantes no Brasil e Estados Unidos da América, sugerindo que, para automóveis, ainda que esta relação se estruture de maneira semelhante, as prioridades entre os tipos motivacionais e os tipos de julgamento diferenciamse nos países estudados devido a diferenças culturais existentes, conforme apontam diversos estudos (Schwartz, 1992, Hofstede, 1980, Triandis, 1991). Torres e Allen (2009), identificaram anteriormente a prioridade no Julgamento Afetivo para brasileiros no processo de escolha de automóveis assim como este estudo. Porém, Torres e Allen (2009) compararam os tipos de julgamento com os australianos, sendo que uma comparação entre Brasil e Estados Unidos da América para Tipos de Julgamento não foi encontrada em estudos anteriores. 


\section{CONCLUSÃO}

O principal objetivo do trabalho foi verificar a influência da idade nos Valores, Julgamento e Atribuição de Significado para escolha de automóveis, pois a literatura indica idade como um segmentador de mercado, sendo comumente utilizado em estratégias de Marketing e propaganda. Para cumprir com o objetivo do trabalho foi realizada uma pesquisa no Brasil e nos Estados Unidos da América, onde foram coletados dados referentes aos Valores, Idade, Julgamento e Atribuição de Signicado. Os resultados indicaram que idade se relaciona com as variáveis deste estudo de forma pequena sendo que nos Estados Unidos da América não ocorreu relação alguma, o que significa que uma segmentação por idade para consumo de automóveis não é recomendada, contrariando a literatura de Marketing sobre o assunto. Verificou-se também que o Julgamento acerca de automóveis no Brasil é predominantemente afetivo enquanto nos Estados Unidos da América é predominantemente passo a passo; os resultados para o Brasil estão condizentes com os estudos já desenvolvidos anteriormente, enquanto os resultados para os Estados Unidos da América não foram verificados em outros trabalhos. Argumenta-se aqui que a diferença se baseie na facilidade de compra e acesso ao automóvel no contexto estadunidense, evitando que o bem seja símbolo de status.

Outro resultado secundário foi a apresentação de um modelo de influência dos Valores no Julgamento e Atribuição de Significado do automóvel. Modelos anteriores utilizavam rotas que se baseavam em Valores, influenciando o tipo de significado que o produto tem para o consumidor para, então, este realizar o julgamento. No modelo proposto por esse trabalho, os Valores também influenciam o tipo de julgamento utilizado, gerando a proposição de que a relação dos Valores com Julgamento e Atribuição de Significado não segue necessariamente uma rota, mas que os Valores influenciam tanto a Atribuição de Significado, como proposto na literatura, como o Julgamento Afetivo. Essa relação foi verificada tanto nos Estados Unidos da América quanto no Brasil, aumentando a robustez do argumento.

Além da relação dos Valores com Julgamento Afetivo encontrada, o presente trabalho também desenvolveu o modo como os Valores se relacionam com os Tipos de Julgamento e Atribuição de Significado. A literatura sobre o tema utiliza os Valores como preditores em conjunto, enquanto esse trabalho buscou verificar quais Valores se relacionavam com cada um dos Tipos de Julgamento e Atribuição de Significado.

Tal relação individualizada permitiu desenvolver um modelo mais claro sobre quais Valores influenciam os Tipos de Julgamento e Atribuição de Significado tanto no Brasil 
quanto nos Estados Unidos da América. Os modelos com essa influência se apresentaram de forma similar, indicando que a estrutura da relação dos Valores com os Tipos de Julgamento e Atribuição de Significado tende a estimular os mesmos construtos.

\subsection{Limitações}

Como limitações para esse estudo indica-se a amostra por conveniência no Brasil. Ainda que a amostra estadunidense também seja por conveniência, ela é oriunda de diversos estados, com maior variabilidade de renda e idade, pois foi coletada por meio de plataforma online, e Paolacci, Chandler e Ipeirotis, (2010) sugerem que amostras coletadas pelo Mturk são mais diversas e melhores que amostras coletadas presencialmente. A amostra brasileira foi coletada na cidade de Brasília somente. Foram coletados dados somente no Brasil e Estados Unidos da América. Pesquisas que utilizam mais países aumentariam o poder de generalização da estrutura do modelo apresentado, uma vez que ainda que a comparação entre os dois países seja uma comparação de uma cultura coletivista, o Brasil com uma cultura individualista, os Estados Unidos da América (Hofstede, 1980) o modelo é semelhante nos dois países pesquisados, pesquisas em mais países comparando países coletivistas e individualistas aumentariam o poder de generalização do modelo.

Por fim, também consideram-se fatores limitadores da pesquisa as variáveis psicológicas utilizadas; a inclusão de outras variáveis como atitude, normas sociais poderiam aumentar a capacidade de predição do modelo desenvolvido.A inclusão de variáveis que podem influenciar o comportamento poderia mediar a relação entre os Valores Humanos e os Tipos de Julgamento e atribuição de Significado, possibilitando a melhor explicação dos mesmos.

\subsection{Agenda de Pesquisa}

Recomenda-se como agenda de pesquisa empreender uma coleta em diversos estados brasileiros, buscando maior variabilidade na amostra, bem como realizar a coleta em outros países para apontar como a relação entre os Valores e os Tipos de Julgamento e Atribuição de Significado ocorre em diferentes contextos. Indica-se também incluir outras variáveis mediadoras e moderadoras da relação entre Valores e Julgamento e Atribuição de Significado como normas e atitudes, pois são variáveis que influenciam no processamento cognitivo do indivíduo, assim afetando o modo como ele se relaciona com as variáveis de Julgamento e Atribuição de Significado. Essa inclusão pode esclarecer melhor a relação entre os Valores 
Humanos e os Tipos de Julgamento e Atribuição de Significado, podendo reproduzir relações mais precisas e úteis para a descrição da preferência e escolha do consumidor.

O presente trabalho foi realizado com somente um produto, o automóvel. Indica-se o teste com outros produtos, com diferentes graus de envolvimento como proposto (Bloch, 1981), que entende que envolvimento ocorre quando um produto é relacionado a importantes necessidades e valores ou ao autoconceito do consumidor. Carros têm um grau de envolvimento muito alto devido ao risco de compra. Será que para produtos com grau de envolvimento mais baixo as relações encontradas seriam as mesmas? Recomenda-se o teste, assim como se recomenda o teste com serviços e marcas, pois produtos são elementos tangíveis enquanto serviços e marcas são elementos intangíveis, portanto, diferentes, possibilitando que a influência dos Valores Humanos Humanos nos Tipos de Julgamento e Atribuição de Significado se realize de forma diferente. 


\section{REFERÊNCIAS}

Abbad, G., \& Torres, C. V. (2002). Regressão múltipla stepwise e hierárquica em Psicologia Organizacional: aplicações, problemas e soluções. Estudos de Psicologia, 7(especial), 1929.

Ajzen, I. (1974). Effects of information on interpersonal attraction: Similarity versus affectivevalue. Journal of Personality and Social Psychology, 29, 374-380.

Ajzen, I., \& Fishbein, M. (1997). Understanding attitudes and predicting social behavior. NJ, Upper Saddle River: Prentice-Hall.

Ajzen, I. (2001). Nature and operation of attitudes. Annual Review of Psychology, 52, 27-58.

Allen, M. W. (1997). The direct and indirect influences of human values on consumer choices. Ph.D. Thesis, University of Wellington, New Zealand.

Allen, M. W. (2000). The attribute-mediation and product meaning approaches to the influences of human values on consumer choices. Em F. Columbus (Org.), Advances

in Psychology Research, v. 1 (pp. 33-76). Huntington, NY: Nova Science Publishers.

Allen, M. W. (2001). A practical method for uncovering the direct and indirect relationships between human values and consumer purchases. Journal of Consumer Marketing, 18(2), 102-120.

Alfinito, S. (2007). A influência de valores humanos e axiomas sociais na escolha do consumidor: Uma análise comparativa aplicada à educação superior. Tese de doutorado, Universidade de Brasília, Brasília, DF, Brasil.

Alfinito, S., Nepomuceno, M. V., \& Torres, C. V. (2012). Advances on the measure of judgment and meaning of the product for Brazil. Artigo não publicado. Instituto de Psicologia, Universidade de Brasília, DF, Brasil.

Allen, M. W., \& Torres, C.V. (2006). Food Symbolism and Consumer Choice in Brazil. Latin American Advances in Consumer Research, 1, 1-6.

Allen, M. W. (1997). The direct and indirect influences of human values on consumers choices (Doctoral thesis). Victoria University of Wellington, Wellington, New Zealand.

Allen, M. W. (2000). The attribute-mediation and product meaning approches to the influences of human values on consumer choices. In Columbus F. H. (Ed.). Advances in psychology research, 1, pp. 31-76. Huntington: Nova Science Pub Inc.

Allen, M. W. (2006a). Human values and product symbolism: Do consumers form product preference by comparing the human values symbolized by a product to the human values that they endorse? Journal of Applied Social Psychology, 32(12), 2475-501. 
Allen, M. W. (2006b). A dual-process model of the influence of human values on consumer choice. Revista Psicologia: Organizações e Trabalho, 6(1), 15-49.

Allport, G.W. (1935). Attitudes. In Murchison C. (Eds.). Handbook of social psychology, pp. 798-844. Worcester, MA: Clark University Press.

Allport, G. W. \& Allport, F. H. (1939). The A-S reaction study. Rev. Edition. Boston: Houghton Mifflin.

Allport, G. W. (1955). Becoming. New Haven, CT: Yale University Press.

Aristóteles. (2001). Ética a Nicômacos. Trad. Mário Gama Kury. 4ed. Brasília: UnB.

Arnould, E. J., Price, L. L., \& Zinkhan, G. M. (2004) Consumers. New York, NY: McGraw-Hill.

Axsen, J.; Orlebar, C., \& Skippon, S. (2014). Social influence and consumer preference formation for pro-environmental technology: The case of a UK workplace electric-vehicle study. Ecological Economics, 95, 96-107.

Babbie, E. (1986). The practice of social research. $4^{\text {th }}$ ed. Belmont, Wadsworth Publ.,

Baltas, G., Saridakis, Ch., (2013). An Empirical Investigation of the Impact of Behavioural and Psychographic Consumer Characteristics on Car Preferences: An Integrated Model of Car Type Choice. Transportation Research Part A: Policy and Practice 54: 92-110.

Barcelos, R. H. (2010). O Consumo da Nova Mídia pelos Adolescentes: Um Estudo

Exploratório de Motivações e Influências. Anais do Encontro Nacional da Associação Nacional de Pós-graduação e Pesquisa em Administração, Salvador, BA, Brasil.

Baudrillard, J. (1991). A Sociedade de consumo. Lisboa: Edições 70.

Bauman, Z. (2008). Vida para o consumo. Rio de Janeiro: Jorge Zahar.

Belleau, D. B., Summers, T. A., Xu Y., \& Pinel R.(2007). Theory of Reasoned Action: Purchase Intention of Young Consumers. Clothing and Textiles Research Journal, 25, 244-57.

Bergstad, C. J., Gamble, A., Hagman, O., Polk, M., Gärling, T., \& Olsson, L. E. (2011). Affective-symbolic and instrumental-independence psychological motives mediating effects of socio-demographic variables on daily car use. Journal of Transport Geography, 19(1), 33-38.

Bilsky, W., \& Schwartz, S. H. (1994). Values and personality. European Journal of Personality, 8, 163-81.

Bilsky, W. (2009). A estrutura de valores: sua estabilidade para além de instrumentos, teorias, idade e culturas. Revista de Administração Mackenzie, 10(3), 12-33. 
Blackwell, R. D., Miniard, P. W., \& Engel, J. F. (2005) Comportamento do consumidor.São Paulo: Thomson Learning.

Bloch, H. P. (1981). An exploration into the scaling of consumer's involvement with a productclass. Advances inconsumer research, 8, 413-417.

Boone, C. E., \& Kurtz, D. L. (1998). Marketing contemporâneo. Rio de Janeiro: LTC.

Boone, Louis E., \& Kurtz, D. L. (2009). Marketing contemporâneo. São Paulo: Cengage Learning.

Bourdieu, P. (1974). The School as a Conservative Force. In Eggleston, J. (ed.) Contemporary Research in the Sociology of Education. London: Methuen.

Bourdieu, P. (1975). The specificity of the scientific field and the social conditions for the progress of reason. Social Science Information, 14(6), 19-47.

Bourdieu, P., \& Passeron J. C. (1979). The Inheritors. Chicago: University of Chicago Press.

Brislin, R. W. (1970) . Back-translation for cross-cultural research. Journal of Cross-Cultural Psychology; 1, 185-216.

Brown, T. A. (2006). Confirmatory Factor Analysis for Applied Research. Guildford: New York.

Bueno, E. (2010). Brasil: uma história - cinco séculos de um país em construção. São Paulo: Leya.

Buhrmester, M. D., Kwang, T., \& Gosling, S. D. (2011). Amazon's Mechanical Turk: A new source of inexpensive, yet high-quality, data? Perspectives on Psychological Science.

Byrne, B. M (2010). Structural Equation Modeling Using AMOS. 2nd ed. New York: Routledge.

Campos, C. B., \& Porto, J. B. (2010). Escala de Valores Pessoais: validação da versão reduzida em amostra de trabalhadores brasileiros. Psico, 41(2), 208-13.

Caprara, G. V., Schwartz, S. H., Capanna, C., Vecchione, M., \& Barbaranelli, C. (2006). Personality and politics: Values, traits, and political choice. Political Psychology, 27, 1-2 doi:10.1111/j.1467- 9221.2006.00447.x

Caulfield, B., Farrel, S., \& McMahon, B. (2010). Examining individuals preferences for hybrid electric and alternatively fuelled vehicles. Transport Policy, 17(6), 381-387.

Chester, E. (2002). Employing generation why. Philadelphia, Chess Press.

Chiu, S.I., Chen, C. C., Yen, T. M., \& Hu, H. Y. (2011). Preliminary research on customer satisfaction models in Taiwan: A case study from the automobile industry. Expert Systems with Applications. 
Churchill, J.R. \& Gilbert A. (1979). A Paradigm for Developing Better Measures of Marketing Constructs. Journal of Marketing Research, 16, 64-73.

Cleaver, M., Green, B. C. \& E. Muller, T. E. (2000). Using Consumer Behavior Research to Understand the Baby Boomer Tourist. Journal of Hospitality \& Tourism Research, 24, 274-87.

Cobra, M.(2009). Administração de marketing no Brasil. São Paulo: Cobra Editora.

Cohen, J. (1992). A power primer. Psychological Bulletin, 112, 155-9.

Davidov, E. Schmidt, P., \& Schwartz, S. H. (2008). Bringing values back in: The adequacy of the European Social Survey to measure values in 20 countries. Public Opinion Quarterly, 72, 420-445. doi:10.1093/poq/nfn035

Demo, G., Fogaça, N., Nunes, I., Edrei, L., \& Francischeto, L. (2011). Políticas de gestão de pessoas no novo milênio: cenário dos estudos publicados nos periódicos da área de Administração entre 2000 e 2010. RAM. Revista de Administração Mackenzie, 12(5), 1542.

De Mooij, M. (2003). Convergence and divergence in consumer behavior: implications for global advertising. Int. J.Advertising, 22(2), 1-20.

Demby, E. H. (1994). Psycographics revisites: the birth of a technique. Marketing Research, 6(2), 26-9.

Dittmar, H. (1992). The Social Psychology of Material Possessions: To Have is to Be. Hemel Hempstead: Harvester Wheatheaf.

Dittmar, H. (2007). Consumer culture, identity and well-being: The search for the good life and the body perfect. In R. Brown (ed.) European Monographs in Social Psychology Series. London: Psychology Press.

Eagly, A.H., \& Chaiken, S. (1993). The psychology of attitudes. Fort Worth, TX: Harcourt Brace Jovanovich.

Economist, The (July, 2010). In Lula's Footsteps. The Economist, 3, 38-40.

Engel, J. F., Blackwell, R. D. \& Miniard, P. W. (2000). Comportamento do consumidor. Rio de Janeiro: JC

Engel, J. F., Kollat, D. T. \& Blackwell, R. D. (1968). Consumer Behavior. NY: Holt, Rinehart\& Winston.

Faria, P. C. N; Oliveira, D. F; Lacerda, T. S; Lara, J. E. (2006). Mapeamento, análise e classificação dos trabalhosacadêmicos de Marketing nos Enanpads de 2000 a 2005 . In: Encontro Nacional da Associação Nacional dos Programas de Pós-Graduação em Administração, 30, 2006, Rio de Janeiro. Anais. Rio de Janeiro: ANPAD. 
Fazio, R. H., Powell, M. C., \& Williams, C. J. (1989). The role of attitude accessibility in the attitude-to-behavior process. Journal of Consumer Research, 16, 280-288.

Fazio, R. H. (1990). Multiple processes by which attitudes guide behavior: The MODE model as an integrative framework. In M. P. Zanna (Ed.), Advances in experimental social psychology, 23 (pp. 75-109). Orlando, FL: Academic Press.

Fazio, R. H., Powell, M. C., \& Williams, C. J. (1989). The role of attitude accessibility in the attitude-to-behavior process. Journal of Consumer Research, 16, 280-8.

Feather N. T (1982). Expectations and Actions: Expectancy-Value Models in Psychology. Hillsdale, NJ: Erlbaum.

Feather, N.T. (1995). Values, valences, and choice: the influence of values on the perceived attractiveness and choice of alternatives. Journal of Personality and Social Psychology, $68,1135-1151$.

Feather, N. T. (1996). Values, deservingness, and attitudes toward high achievers: Research on tall poppies. In C. Seligman, J. M. Olson, \& M. P. Zanna (eds.), The Ontario Symposium: v. 8. The psychology of values, pp. 215-251). Mahwah, NJ: Erlbaum.

Featherstone, M. (1995). Cultura de consumo e pós-modernismo. São Paulo: Studio Nobel.

Ferber, R. (1984). What do we know about consumer behavior? - marketing management and strategy. New York: Prentice-Hall.

Ferreira, M.C.; Fernandes, H. A.; Corrêa e Silva, A. P. (2009). Valores organizacionais: um balanço da produção nacional do período de 2000 a 2008 nas áreas de administração e psicologia. RAM. Revista de Administração Mackenzie, v. 10 n. 3, p. 84-100.

Field, A. P. (2009). Discovering statistics with SPSS. London, Sage.

Finotti, M. A. (2004). Estilos de Vida: Uma Contribuição ao Estudo da Segmentação de Mercado. Dissertação de Mestrado, São Paulo, Universidade de São Paulo.

Fishbein, M. \& Ajzen, I. (1975). Belief, attitude, intention and behavior: an introduction to theory and research. Menlo Park. CA: Addison-Wesley Publishing Co.

Fishbein, M. (1966). The relations between beliefs, attitudes and behavior. New York: Academic Press.

Fishbein, M. (1967). Attitude and the prediction of behavior. In Fishbein M. (Ed.). Readings in attitude theory and measurement (pp. 477-92). New York: Wiley.

Fishlow, A. (2011). O Novo Brasil: As conquistas políticas, econômicas, sociais e nas relações internacionais. São Paulo, Saint Paul. 
Fiske, S. T., \& Pavelchak, M. (1986). Category-based versus piecemeal-based affective responses: Developments in schema-triggered affect. In R. M. Sorrentino \& E. T. Higgens (Eds.). The handbook of motivation and cognition: Foundations of social behavior pp. 167-203. New York: Guilford.

Franke, T.; Krems, J. (2013). What drives range preferences in electric vehicle users? Transport Policy, 30, 56-62.

Fraser, C. (1994). Attitudes, social representations and widespread beliefs. Papers on Social Representations, 3(1), 1-38.

Gabor, M. R.; Contiu, L. C. (2012). Is dacia-logan Car Brand on the First Place of Romanian Youth Preferences? Testing the Influence of Advertising Campaigns with Nonparametric Statistics. Procedia-Social and Behavioral Sciences, 58, 1344-1352.

Gade, C. (1980). Psicologia do consumidor. São Paulo: EPU.

Gade, C. (1998). Psicologia do consumidor e da propaganda. São Paulo: E.P.U.

Giambiagi, F., Villela, A, Castro B. C., \& Hermann, J. (2005). Economia Brasileira Contemporânea (1945-2004). São Paulo: Campus.

Giglio, E. (1996). Comportamento do consumidor e a gerência de marketing. São Paulo: Pioneira.

Goergen P. (2005). Educação e valores no mundo contemporâneo. Educ. Soc. 26, 92, 9831011.

Gonçalves Filho, C., Fernandes, B. P., Souki, G. Q., \& Dias, A. T. (2013). Estilos de vida e valores de consumidores. Um estudo de grupos psicográficos no mercado automotivo de Belo Horizonte. Revista Alcance, 20(1), 006-021.

Grisi, C. C. H. (1986). Contribuições ao Estudo das Técnicas de Segmentação de Mercado Uma Análise de Dados Sobre Apostadores da Loteria Federal. Dissertação de Mestrado. Universidade de São Paulo.

Grubb, E. L., \& Grathwohl, H. (1967). Consumer self-concept, symbolism and market behavior: a theoretical approach. Journal of Marketing, 22-7.

Günther, H. (1981). Uma tentativa de traduzir e adaptar a Escala de Valores de Rokeach para uso no Brasil. Arquivos Brasileiros de Psicologia, 33, 58-72.

Hachbarth, A., \& Madlener, R. (2013). Consumer preferences for alternative fuel vehicles: A discrete choice analysis. Transportation Research Part D: Transport and Environment, 25, 5-17.

Hair, F. J., Black, W.C., Babin, B., Anderson, R. E., \& Tathan, R. L. (2009). Análise multivariada de dados.Porto Alegre: Bookman. 
Haugtvedt, C. P., Herr, P. M., \& Kardes, F.R. (2008). Handbook of Consumer Psychology. CRC Press.

Hawkins, D.I., Mothersbaugh, D.L. \& Best, R.J. (2007). Comportamento do Consumidor: Construindo a Estratégia de Marketing. Rio de Janeiro: Campus.

Healy, M. J. R. (1984). The use of $\mathrm{R}^{2}$ as a measure of goodness of fit, Journal of Royal Statistical Society. 147:608-609

Heider, F. (1967). Attitudes and cognitive organization. In Fishbein M. (ed.). Readings in attitude theory and measurement, pp. 39-41. New York: Wiley.

Hill, R. (1970). Family Development in Three Generations. Cambridge: Schenkman Publishing Company.

Hills, M. D. (2002). Kluckhohn and Strodtbeck's values orientation theory. In: Lonner, W. J. et al. (Ed.). Online readings in psychology and culture. Bellingham, Washington: Center for Cross-Cultural Research, Western Washington University.

Hirschman, E. C. \& Holbrook M. B. (1982). Hedonic Consumption: Emerging Concepts, Methods and Propositions. Journal of Marketing, 46, 3, 92-101.

Hofstede, G. (1980). Culture's consequences. Beverly Hills,CA: Sage.

Hooley, G. \& Saunders J. (1993). Competitive positioning: A key to market success. London: Prentice-Hall.

Howard, J.A., \& Sheth, J. N. (1969). The Theory of Buyer Behavior. John Wiley \& Sons, New York.

Hoyer, W., \& MacInnis, D. (2010). Consumer behavior. Boston: South-Western Cengage Learning.

Hunt, S. (1991). Positivism and paradigm dominance in consumer research: toward critical pluralism and rapprochement. Journal of Consumer Research, 18, 32-44.

Iglesias, F., \& Alfinito, S. (2006). A abordagem multi metodológica em comportamento do consumidor: Dois programas de pesquisa na oferta de serviços. Psicologia: Organizações e trabalho, 6(1), 138-65.

Inglehart, R. (1981). Post-materialism in an environment of insecurity. American Political Science Review, 75, 880-900.

Instituto De Pesquisa Econômica Aplicada - IPEA. Consumo de bens duráveis, não duráveis e de consumo. Disponível em < http://www.ipeadata.gov.br > . Acesso em 08.03.2012.

Jato, R., \& Litcht, R. H. G.(2009). Escolhas Associadas ao Automóvel por Homens e por Mulheres: confluência ou divergência?. Revista Brasileira de Gestão de Negócios, 11(30), 53-64. 
Kahle L. R. (1983). Social values and social change: adaptation to life in America. New York: Praeger.

Kahle, L. R., Beatty, S. E., \& Homer, P. (1986). Alternative Measurement Approaches to Consumer Values: The List of Values (LOV) and Values and Life Styles (VALS). Journal of Consumer Research, 13(3), 405-9.

Kahle, L. R., \& Kennedy, P. (1988). Using the list of values to understand consumers. Journal of consumer marketing, 6(3), 5-12.

Kahle L. R., Rose G., \& Shoham A. (2000). Findings of LOV throughout the world and other evidence of cross-national consumer psychographics: introduction. In: Kahle L. R. (ed.). Cross-national consumer psychographics, pp. 1 - 13. New York, Haworth Press.

Kamakura, W. A., \& Novak, T. P. (1992). Value-system segmentation: exploring the meaning of LOV. Journal of consumer research, 19, 119-32.

Kant, I. (2002). Crítica da Razão Prática. São Paulo: Martins Fontes.

Karsaklian, E. (2009). Comportamento do consumidor. São Paulo: Atlas.

Kassarjian, H. H. (1981). Perspectives in consumer behavior. Illinois: Scott \& Foresman.

Katz, D. (1960). The functional approach to the study of attitudes. Public Opinion Quarterly, 24, 163-204.

Kergoat, M., Giboreau, A., Nicod, H., Faye P., Diaz, E., Beetschen, M. A., Gerritsen, N., \& Meyer, T. (2010). Psychographic measures and sensory consumer tests: When emotional experience and feeling-based judgments account for preferences. Food quality and preference, 21(2), 178-187.

Kim, E. Y., Knight, D. K., \& Pelton, L. E. (2009). Modeling Brand Equity of a U.S. Apparel Brand as Perceived by Generation Y Consumers in the Emerging Korean Market.Clothing and Textiles Research Journal, 27, 247-58.

Klem, L. (1995) Path analysis. In: Grimm, L. G. \& Yarnold, P. R. (1995). Reading and understanding multivariate statistics. Washington, DC: American Psychological Association.

Kluckhohn, F. R., \& Strodtbeck, F. L. (1961). Variations in value orientations. Evanston, IL: Row, Peterson.

Kluckhohn, C. (1951). Values and value-orientations in the theory of action: An exploration in definition and classification. In T. Parsons \& E. Shils (Orgs.), Toward a general theory of action (pp. 469-506). Cambridge: Harvard University Press.

Koetse, M. J., \& Hoen, A. (2014). Preferences for alternative fuel vehicles of company car drivers. Resource and Energy Economics. 
Kotler, P. (2006). Administração de marketing. São Paulo: Atlas.

Kuehn, A., \& Day, R. L. (1964). Probabilistic models of consumer buying behavior. In: Day, Ralph L. (Ed.). Marketing models: quantitative and behavioral. Scranton: International Textbook Company.

Laux, F. N., Almeida, S. O., \& Pereira, R. C. F. (2008). Marketing de Gerações: Construção e Teste de Escala para Avaliação da Marca de Refrigerante Coca-Cola por Jovens na Fase de Transição entre as Gerações X e Y. Anais do Encontro Nacional da Associação Nacional de Pós-graduação e Pesquisa em Administração, Salvador, BA, Brasil, 30.

Laville, C., \& Dionne, J. (1999). A construção do saber: manual de metodologia da pesquisa em ciências humanas. Belo Horizonte: UFMG.

Lazarus, R. S. (1984). On the primacy of cognition. American Psychologist, 39, 124-129.

Lehto, X. Y., Jang S. C., Achana F. T., \& O'Leary, J. T. (2008). Exploring tourism experience sought: A cohort comparison of Baby Boomers and the Silent Generation. Journal of Vacation Marketing, 14, 237-52.

Lemos, I. D. (2010). O impacto de diferenças individuais referentes a aspectos psicológicos do consumidor feminino no comportamento de compra: um estudo empírico no mercado de moda. Dissertação de Mestrado. Universidade FUMEC, São Paulo, SP, Brasil.

Lewin, K. (1942). Field theory and learning. In Cartwright D. (Ed.). Field theory in social science, pp. 60-86. New York: Harper \& Row.

Lindberg, E., Garling T., \& Montgomery, H. (1989). Belief-Value Structures as Determinants of Consumer Choice: A Study of Housing Preferences and Choices. Journal of Consumer Policy, 12, 119-137.

Lindquist, D. J., \& Sirgy, M. J. (2006). Shopper, Buyer and Consumer Behavior. Ohio: Atomicdog Publishing.

Mancebo D., Oliveira, D. M., Fonseca, J. G. T., \& Silva, L. V. (2002). Consumo e subjetividade: trajetórias teóricas.Estudos de Psicologia, 7(2), 325-332.

Mannheim, K. (1952). The Problem of Generations: Essays on the Sociology of Knowledge. New York: Oxford Univ. Press.

Markin, R. J. (1979). The role of rationalization in consumer decision processes: a revisionist approach to consumer behavior. Journal of the Academy of Marketing Science, 7(4), 31634.

Marôco, J. P. (2010).Análise de Equações Estruturais: Fundamentos teóricos, Software \& Aplicações. Pêro Pinheiro: ReportNumber. 
Marôco, J. P. (2011) Análise Estatística com o SPSS Statistics. 5 ${ }^{\mathrm{a}}$ Ed. Pêro Pinheiro: ReportNumber.

Martin, C. \& Tulgan, B. (2006). Managing the generation mix. Amherst, HRD Press

Martins Filho, I. G. (2011). História do Brasil: Resumo esquemático. $2^{\mathrm{a}}$ Ed. São Paulo: LTr.

Maruyama, G. M. (1998). Basics of structural equation modeling. London: Sage Publications.

Maslow, A. (1987). Motivation and personality. Harper \& Row, New York.

Mazzon, J. A., \& Hernandez, J. M. C. (2013). Produção científica brasileira em marketing no período 2000-2009. RAE-Revista de Administração de Empresas, 53, 67-80.

McAlister, L. \& Pessemier, E. (1982). Variety seeking behavior: an interdisciplinary review. Journal of Consumer Research, 9(3), 182-204.

McDonald, M. \& Dunbar, I. (1995). Marketing segmentation: a step-by-step approach to creating profitable markets segments. London: Macmillan Business.

Mcguire, W. G. (1969). The nature of attitudes and attitude change. In: Lindzey, G. \& Aronson, E. (Org.). Handbook of social psychology. $2^{\text {nd }}$ ed., pp. 136-314. Reading: Addison-Wesley.

McIntyre, R. P., Claxton, R. P., \& Jones, D. B. (1994). Empirical relationships between cognitive style and LOV: implications for values and value systems. Advances in consumer research, 21.

Mendonça, H., \& Tamayo, A. (2008). Valores Pessoais e Retaliação Organizacional: Estudo em uma Organização Pública. RAC-Eletrônica, 2(2), 189-200.

Miles, J.\& Shevlin, M. (2001). Applying regression and correlation. Sage Publications, London

Moral, M. J., \& JaumandreU, J. (2007). Automobile demand, model cycle and age effects. Spanish Economic Review, 9(3), 193-218.

Morton, L.P. (2002) Targeting Generation Y. Public Relations Quarterly, 46-48.

Mowen, J. C., \& Minor, M. S. (2003) Comportamento do consumidor. São Paulo: Prentice Hall.

Myers, J. H., \& Reynolds W. H. (1967). Consumer Behavior and Marketing Management. Boston: Houghton Mifflin Company.

Nepomuceno, M. V., \& Torres, C. V. (2005). Validação da escala de julgamento e significado do produto. Estudos de Psicologia, 10(3), 421-30.

Nicosia, F. M. (1966). Consumer Decision Processes. Prentice Hall, Englewood Cliffs, New Jersey. 
Norberto, E. (2004). Estratégias corporativas de marcas e estratégias sociais de diferenciação - uma análise a partir do automóvel. Tempo Social, revista de sociologia da USP, 16(2), $203-233$

Nunnaly, J. C. \& Bernstein, I. H. (1994). Psychometric theory. New York; McGrawHill.

Paolacci, G., Chandler, J., \& Ipeirotis, P. G. (2010). Running experiments on Amazon Mechanical Turk. Judgment and Decision Making, 5, 411-419.

Parsons, T. (1937). The structure of social action. McGraw \& Hill, New York.

Paschoal, T., \& Tamayo, A (2005). Impacto dos valores laborais e da interferência famíliatrabalho no estresse ocupacional. Psicologia: Teoria e Pesquisa, 21(2), 173-180

Pasquali,L. (2009). Psicometria:Teoria dos testes na psicologia e na educação (3. ed.). Petrópolis, RJ: Vozes

Pasquali, L. (2010). Instrumentação Psicológica: Fundamentos e Práticas. Porto Alegre: Artmed.

Pasquali, L. (2012). Análise fatorial para pesquisadores. Petrópolis: Ed. Vozes.

Paulino, I. R. (2006). Um olhar sobre a degradação dos valores humanos a partir da obra os sonâmbulos, de Hermann Broch (Dissertação de Mestrado). Universidade de Brasília, Brasil.

Perin, M. G., Sampaio, C. H., Froemming, L. M. S., \& Luce, F. B. (2000). A pesquisa survey em artigos de Marketing nos Enanpads da década de 90. Anais do Encontro Nacional da Associação Nacional dos Programas de Pós-Graduação em Administração, Florianópolis, SC, Brasil, 24.

Peter, J. P., \& Olson, J. C. (1993). Consumer behavior and marketing strategy. Homewood, IL: Richard D. Irwin, Inc.

Piirto, R. (1991). Beyond mind games: The marketing power of psychographics. Ithaca, NY: American Demographics Books.

Pinheiro, R. M., \& Castro, G. C. (2006). Comportamento do consumidor e pesquisa de mercado. Rio de Janeiro: Editora FGV.

Pinto, M. R., \& Lara, J. E. (2007). A pesquisa na área do comportamento do consumidor: uma análise da produção acadêmica brasileira entre 1997 e 2006. Anais do Encontro Nacional da Associação Nacional de Pós-graduação e Pesquisa em Administração, Salvador, BA,Brasil, 30.

Plummer, J. (1974). The concept and application of life style segmentation. Journal of Marketing, 38, 34. 
Porto, J. B., \& Campos, C. B. (2007). Escala de valores pessoais: validação da versão reduzida em Amostra de trabalhadores brasileiros. Psico, 41(2), 208-213.

Porto, R. B. (2005). Valores humanos pessoais e significados do produto como preditores de preferência por tipos de automóveis. Dissertação de Mestrado (Dissertação ainda não publicada). Universidade de Brasília, Brasil.

Porto, R. B., \&Torres, C. V. (2012). Comparações entre preferência e posse de carro: predições dos valores humanos, atributos do produto e variáveis sociodemográficas. Revista de Administração, 47(1), 140-154.

Puente-Palacios, K. E., \& Laros, J. A. (2009). Análise multinível: contribuições para estudos sobre efeito do contexto social no comportamento individual. Estud Psicol (Campinas), 26, 349-61.

Qian, L., \& Soopramanien , D. (2011). Heterogeneous consumer preferences for alternative fuel cars in China. Transportation Research Part D: Transport and Environment, 16(8), 607-613.

Qian, L., \& Soopramanien, D. (2014). Incorporating heterogeneity to forecast the demand of new products in emerging markets: Green cars in China. Technological Forecasting and Social Change.

Ramalho, R., \& Ayrosa, E. A. T. (2009). Subcultura tuning: a identidade estendida na personalização de automóveis. Revista de Ciências da Administração. 11(24), 169-194.

Rees, P., \& Gardner, H. (2005). Political marketing segmentation: the case of UK local government. In: Wymer, W. W. \& Lees-Marshment, J. (eds.). Current issues in political marketing, pp. 169-84. New York: Haworth Press.

Remke, R, Raines, C., \& Filipczak R. (2000). Generations at work. New York: Amacom.

Rentz, J. O., Reynolds, F. G., \& Stout, R. G. (1983). Analyzing Changing Consumption Patterns with Cohort Analysis. Journal of Marketing Research, 20, 12-20.

Rentz, J. O., \& Reynolds, F. G. (1991). Forecasting the Effects of an Aging Population on Product Consumption: An Age-Period-Cohort Framework. Journal of Marketing Research, 28, 355-60.

Ribeiro, D. (1995).O povo brasileiro. São Paulo: Cia. das Letras.

Rindfleisch, A. (1994). Cohort Generational Influences on Consumer. Advances in Consumer Research, 21, 470-76.

Rodrigues, A., Assmar, E. M. L., \& Jablonski, B. (2000). Psicologia social. Petrópolis: Vozes. 
Rohan, M. J. (2000). A rose by any name? The values construct. Personality and Social Psychology Review, 4, 255-77.

Rokeach, M. (1973). The nature of human values. New York: Free Press.

Rokeach, M. (1979). Understanding Human Values.New York: Free Press.

Rose, N. (2008). Psicologia como uma ciência social. Psicologia \& Sociedade, 20(2), 155-64.

Ryder, N. B. (1965). The cohort as a concept in the study of social change. American Sociological Review, 30, 843-61.

Sagiv, L., \& Schwartz, S. H. (1995). Value priorities and readiness for out-group social contact. Journal of Personality \& Social Psychology, 69(3), 437-48.

Samara, B. S. \& Morsch, M. A. (2005). Comportamento do consumidor: conceitos e casos. São Paulo: Prentice Hall.

Sandhusen, R. L. (1998). Marketing básico. São Paulo: Saraiva.

Schaie, K. W., Labouvie, G. V., \& Buech, B. U. (1973). Generational and cohort-specific differences in adult cognitive functioning: A fourteen-year study of independent samples. Developmental Psychology, 9, 151-166.

Schiffman, L. G., \& Kanuk, L. L. (2000). Comportamento do consumidor. $6^{\text {a }}$ ed. São Paulo: LTC.

Schumann, D. W., Haugtvedt, C. P., \& Davidson, E. (2008). History of consumer psychology. In C. P. Haugtvedt, P.M. Herr, \& F. R. Kardes (Ed.). The Handbook of Consumer Psychology, pp. 3-28. New York, NY: Taylor \& Francis Group.

Schwartz, S. H. (1992). Universals in the content and structure of values: theoretical advances and empirical tests in 20 countries. In Zanna, M. P. (Org.),Advances in experimental social psychology,pp. 1-65. Orlando, FL: Academic Press.

Schwartz, S. H. (2005). Valores humanos básicos: seu contexto e estrutura intercultural. In: Tamayo, A.; Porto, J. (Orgs.). Valores e comportamento nas organizações, pp. 21-55. Petrópolis: Vozes.

Schwartz, S. H., \& Bilsky, W. (1987). Toward a universal psychological structure of human values. Journal of Personality and Social Psychology, 53, 550-62.

Schwartz, S. H., \& Bilsky, W. (1990). Toward a theory of the universal content and structure of values: Extensions and cross-cultural replications. Journal of Personality and Social Psychology, 58, 878-891. 
Schwartz, S. H., Cieciuch, J., Vecchione, M., Davidov, E., Fischer, R., Beierlein, C.,

Ramos, A., Verkasalo, M., Lönnqvist, J.-E., Demirutku, K., Dirilen-Gumus, O., \&

Konty, M. (2012). Refining the theory of basic individual values. Journal of Personality and Social Psychology, 103,663-688.

Schwartz, S. H., Melech, G., Lehmann, A., Burgess, S., Harris, M., \& Owens, V. (2001). Extending the Cross-Cultural Validity of the Theory of Basic Human Values with a Different Method of Measurement. Journal of Cross-Cultural Psychology, 32, 519.

Scripture, E. W. (1895). Thinking, feeling, doing. Meadville, PA: Flood and Vincent.

Sheth, J., Gardner, D., \& Garrett, D. (1988). Marketing theory: evolution and evaluation.New York: John Wiley \& Sons.

Sheth, J. N., Mittal, B., \& Newman, B. I. (2001). Comportamento do cliente: indo além do comportamento do consumidor. São Paulo: Atlas.

Shimp, T. A. (2002). Propaganda e promoção: aspectos complementares da comunicação integrada de marketing. $5^{\mathrm{a}}$ ed. Porto Alegre: Bookman.

Short, J. C., \& Reeves, T. C. (2009). The Graphic Novel: a "Cool" Format for Communicating to Generation Y. Business Communication Quarterly,72, 414-30.

Silva, A. R. (2007). Influência dos Valores Humanos, Tipo de Julgamento e Atribuição de Significado na Intenção de Voto ao Cargo de Governador do Distrito Federal. Dissertação de Mestrado, Universidade de Brasilia, Brasil.

Simonson, I., Carmon, Z., Dhar, R., Drolet, A., \& Nowlis, S. M. (2001). Consumer research: in search of identity. Annual Review of Psychology, 52, 249-75.

Siqueira, A. C. B. (2000). Segmentação de mercados industriais.São Paulo: Atlas.

Siren, A., \& Haustein, S. (2013). Baby boomers' mobility patterns and preferences: What are the implications for future transport? Transport Policy, 29,136-144.

Sirgy, J. (1982) Self-concept in consumer behaviour: A critical review. Journal of Consumer Research, 9(3), 287-300.

Smith, P. B., \& Bond, M. H. (1999). Social psychology across cultures. Massachusetts: Allyn and Bacon.

Smith, G., \& Hirst, A. (2001). Strategic political segmentation. European Journal of Marketing, 35, 1058-73.

Smith, W. (1956). Product differentiation and market segmentation as alternative marketing strategies. Journal of Marketing, 21, 3-8.

Snyder, M., \& Kendzierski, D. (1982). Acting on one's attitudes: Procedures for linking attitude and behavior. Journal of Experimental Social Psychology, 18, 165-183. 
Solomon, M. R. (2002). O comportamento do consumidor: comprando, possuindo e sendo. $5^{\mathrm{a}}$ ed. Porto Alegre: Bookman.

Soutar, G., Grainger, R., \& Hedges, P. (1999). Australian and Japanese value stereotypes: A two country study. Journal of Internatinal Business Studies, 30(1), 203-217.

Statt, D. A. (1997). Understanding the consumer: a psychological approach. London: MacMillan.

Stern, W. (1911). Die differentielle Psychologie in ihren methodischen Grundlagen [Methodological Foundations of Differential Psychology]. Leipzig: Barth.

Stigler, G. J. (1954). The Early History of Empirical Studies of Consumer Behavior. The Journal of Political Economy, 62(2), 95-113.

Stockard, J., Carpenter, G., \& Kahle, L. R. (2014). Continuity and Change in Values in Midlife: Testing the Age Stability Hypothesis. Experimental aging research, 40(2), 224-244.

Strauss, W., \& Howe, N. (1991). Generations: The History of America's Future, 1584 to 2069. New York: Morrow.

Tabachinik, B. G., \& Fidell, L.S. (2001). Using multivariate statistics.New York: TheGuilford Press.

Tamayo, A., \& Schwartz, S. H. (1993). Estrutura motivacional dos valores humanos. Psicologia: Teoria e Pesquisa, 9(2), 329-48.

Tamayo, A. (2007). Contribuições ao Estudo dos Valores Pessoais, Laborais e Organizacionais. Psicologia: Teoria e Pesquisa, 23, 17-24.

Tellis, G. J; Chandy, R. K; Ackerman, D. S. (1999). In search of diversity: the record of major Marketing journals. Journal of Marketing Research, v. 36, n. 1, p. 120-131.

Thomas, W. U., \& Znaniecki, F. (1918). The Polish peasant in Europe and America. Boston, Badger.

Thurstone, L. L. (1928). Attitudes can be measured. American Journal of Sociology, 33, 52954.

Tomanari, S. A. A. (2003). Segmentação de mercado com enfoque em valores e estilo de vida (segmentação psicográfica) - um estudo exploratório. Dissertação de Mestrado. Universidade de São Paulo, São Paulo, SP. Brasil.

Torres, C. V., \& Allen, M. W. (2009). Human values and consumer choice in Australia and Brazil. Psicologia - Teoria e Pesquisa, 25(4), 489-97.

Torres, C. V. \& Dessen, M. A. (2008). Brazilian culture, family, and its ethnic-cultural variety. Journal of Hispanic Cultural Studies, 12, 41-62. 
Torres, C. V., \& Neiva E. R. (2011). Psicologia social: Principais temas e vertentes. São Paulo: Artmed.

Torres, C. V., Schwartz, S. H., \& Nascimento, T. G. (2014). A Teoria de Valores Refinada e suas Relações com Comportamento. Manuscrito submetido para publicação.

Triandis, H. C. (1991). Attitude and attitude change. In Encyclopedia of Human Biolology (Vol. 1, pp. 485-496). San Diego, CA: Academic Press.

Tulgan, B. (1997) The manager's pocket guide to generation X. Amherst, MA: HRD Press.

Van Rijnsoever, F.; Farla, J.; Dijst, M. J. (2009). Consumer car preferences and information search channels. Transportation Research Part D: Transport and Environment, 14(5), 334-342.

Vieira, V. A. (2002). Fazendo uma revisão nas áreas de influência no comportamento do consumidor. REAd. Revista Eletrônica de Administração. 8(5), 1-13.

Vieira, F. G. D. (2003). Narciso sem espelho: a publicação brasileira de Marketing. RAERevista de Administração de Empresas, 43(1), 81-90.

Vrkljan, B. H., \& Anaby, D. (2011). What vehicle features are considered important when buying an automobile? An examination of driver preferences by age and gender. Journal of safety research, 42(1), 61-65.

Wänke, M. (2009) Social psychology of consumer behavior. New York, Psychology Press.

Watanabe, E.A.M. (2014). A influência da cultura no comportamento do consumidor de supermercados. Tese de Doutorado não Publicada. Universidade de Brasília.

Weinstein, A. (1995) Segmentação de mercado. São Paulo: Atlas.

Wells, W. D., \& Tigert, D. J. (1971). Activities, interests and opinions. Journal of Advertising Research [S.1.].

West, S. G., Finch, J. F., \& Curran, P. J. (1995). Structural equation models with non-normal variables. In R. H.Hoyle (Ed.), Structural equation modeling: Concepts, issues and applications (pp. 56-75). Thousand Oaks, CA: Sage

Wind, Y. (1978). Issues and advances in segmentation research. Journal of Marketing Research [S.1.], 15, 313-37.

Wu, W. Y.; Liao, Y. K; Chatwuthikrai, A. (2014). Applying conjoint analysis to evaluate consumer preferences toward subcompact cars. Expert Systems with Applications, 41(6), 2782-2792.

Zajonc, R.B. (1980). Feeling and thinking: preferences need no inferences. American psychologist, 35(2), 151-175. 
Zhan, J., Porter, M. M., Polgar, J., \& Vrkljan, B. (2013). Older drivers' opinions of criteria that inform the cars they buy: A focus group study. Accident Analysis \& Prevention, 61, 281-287.

Zill, N. \& Robinson, J. (1995). The Generation X Differences. American Demographics, 2433. 


\begin{abstract}
ANEXO
Você está sendo convidado(a) a responder um questionário sobre como as pessoas tomam decisões corriqueiras em suas vidas, esta pesquisa é parte de uma tese de doutorado sobre comportamento de consumo desenvolvida no departamento de pós-graduação em Administração na UNB. Nós estamos interessados em como você toma a decisão a respeito de um automóvel (carro, caminhonete, utilitário, etc). Queremos saber o quanto você acha que as seguintes afirmativas são se aplicam ou não para você. Por favor, leia cada uma das sentenças abaixo e marque o número 10 se você concorda totalmente com a sentença; marque o número 1 se você discorda totalmente com a sentença; ou marque qualquer número entre 2 e 9 que melhor reflita a sua opinião. Veja que não existem respostas certas ou erradas. O questionário não é uma prova, apenas uma pesquisa de opinião. Suas respostas são confidenciais e anônimas.
\end{abstract}

VALORES

Sem importância

Muito importante

\begin{tabular}{|l|l|l|l|l|l|l|l|l|l|}
\hline $\begin{array}{l}\text { 1) Reconhecimento Social (Ser aceito e necessário para } \\
\text { minha família, amigos e comunidade) }\end{array}$ & 1 & 2 & 3 & 4 & 5 & 6 & 7 & 8 & 9 \\
\hline $\begin{array}{l}\text { 2) Uma vida excitante (Ter experiências estimulantes e } \\
\text { emocionantes). }\end{array}$ & 1 & 2 & 3 & 4 & 5 & 6 & 7 & 8 & 9 \\
\hline $\begin{array}{l}\text { 3) Relacionamentos afetuosos com outras pessoas (Ter } \\
\text { amigos próximos e amizades verdadeiras). }\end{array}$ & 1 & 2 & 3 & 4 & 5 & 6 & 7 & 8 & 9 \\
\hline $\begin{array}{l}\text { 4) Autorrealização (Ter paz interior e fazer melhor uso } \\
\text { de minhas capacidades. }\end{array}$ & 1 & 2 & 3 & 4 & 5 & 6 & 7 & 8 & 9 \\
\hline $\begin{array}{l}\text { 5) Ser respeitado (Ser admirado e reconhecido pelos } \\
\text { outros). }\end{array}$ & 1 & 2 & 3 & 4 & 5 & 6 & 7 & 8 & 9 \\
\hline $\begin{array}{l}\text { 6) Aproveitar a vida (Ter uma vida prazerosa e feliz) } \\
\text { 7) Segurança (Sentir-me seguro e protegido contra } \\
\text { desgraças e ataques). }\end{array}$ & 1 & 2 & 3 & 4 & 5 & 6 & 7 & 8 & 9 \\
\hline $\begin{array}{l}\text { 8) Autorrespeito (Orgulhar-me de mim mesmo e ser } \\
\text { confiante de quem sou). }\end{array}$ & 1 & 2 & 3 & 4 & 5 & 6 & 7 & 8 & 9 \\
\hline $\begin{array}{l}\text { 9) Sentimento de realização (Obter êxito naquilo que } \\
\text { faço). }\end{array}$ & 1 & 2 & 3 & 4 & 5 & 6 & 7 & 8 & 9 \\
\hline
\end{tabular}


Descrevemos resumidamente abaixo diferentes rapazes. Leia cada descrição e considere o quanto cada um desses rapazes é semelhante a você ou não. Assinale com um "X" a opção que indica o quanto o rapaz descrito se parece com você.

\begin{tabular}{|c|c|c|c|c|c|c|}
\hline & \multicolumn{6}{|c|}{ Quanto este rapaz se parece com você? } \\
\hline & $\begin{array}{c}\text { Não se } \\
\text { parece } \\
\text { nada } \\
\text { comigo }\end{array}$ & $\begin{array}{l}\text { Não se } \\
\text { parece } \\
\text { comigo }\end{array}$ & $\begin{array}{c}\text { Se } \\
\text { parece } \\
\text { pouco } \\
\text { comigo }\end{array}$ & $\begin{array}{c}\text { Se } \\
\text { parece } \\
\text { mais } \\
\text { ou } \\
\text { menos } \\
\text { comigo } \\
\end{array}$ & $\begin{array}{c}\text { Se } \\
\text { parece } \\
\text { comigo }\end{array}$ & $\begin{array}{c}\text { Se } \\
\text { parece } \\
\text { muito } \\
\text { comigo }\end{array}$ \\
\hline $\begin{array}{l}\text { 1) É importante para ele ter a sua própria } \\
\text { compreensão das coisas. }\end{array}$ & & & & & & \\
\hline $\begin{array}{l}\text { 2) É importante para ele que haja estabilidade e } \\
\text { ordem na sociedade como um todo. }\end{array}$ & & & & & & \\
\hline 3) É importante para ele se entreter. & & & & & & \\
\hline 4) É importante para ele evitar chatear as pessoas. & & & & & & \\
\hline $\begin{array}{l}\text { 5) É importante para ele proteger as pessoas fraca } \\
\text { e vulneráveis na sociedade. }\end{array}$ & & & & & & \\
\hline $\begin{array}{l}\text { 6) É importante para ele que as pessoas façam o } \\
\text { que ele diz que deveriam fazer. }\end{array}$ & & & & & & \\
\hline $\begin{array}{l}\text { 7) É importante para ele nunca se vangloriar ou se } \\
\text { fazer de arrogante. }\end{array}$ & & & & & & \\
\hline 8) É importante para ele tomar conta da natureza. & & & & & & \\
\hline $\begin{array}{l}\text { 9) É importante para ele que ninguém jamais o } \\
\text { envergonhe. }\end{array}$ & & & & & & \\
\hline $\begin{array}{l}\text { 10) É importante para ele sempre procurar coisas } \\
\text { diferentes para fazer. }\end{array}$ & & & & & & \\
\hline $\begin{array}{l}\text { 11) É importante para ele cuidar das pessoas das } \\
\text { quais ele se sente próximo. }\end{array}$ & & & & & & \\
\hline $\begin{array}{l}\text { 12) É importante para ele ter o poder que o } \\
\text { dinheiro pode trazer. }\end{array}$ & & & & & & \\
\hline $\begin{array}{l}\text { 13) É muito importante para ele evitar doenças e } \\
\text { proteger a sua saúde. }\end{array}$ & & & & & & \\
\hline $\begin{array}{l}\text { 14) É importante para ele ser tolerante com todos } \\
\text { os tipos de pessoas e grupos. }\end{array}$ & & & & & & \\
\hline $\begin{array}{l}\text { 15) É importante para ele nunca violar as regras } \\
\text { ou regulamentos. }\end{array}$ & & & & & & \\
\hline $\begin{array}{l}\text { 16) É importante para ele tomar suas próprias } \\
\text { decisões a respeito da sua vida. }\end{array}$ & & & & & & \\
\hline 17) É importante para ele ter ambições na vida. & & & & & & \\
\hline $\begin{array}{l}\text { 18) É importante para ele manter tanto os valores, } \\
\text { quanto as formas de pensar tradicionais. }\end{array}$ & & & & & & \\
\hline $\begin{array}{l}\text { 19) É importante para ele que as pessoas que ele } \\
\text { conhece tenham total confiança nele. }\end{array}$ & & & & & & \\
\hline 20) É importante para ele ser rico. & & & & & & \\
\hline $\begin{array}{l}\text { 21) É importante para ele tomar parte nas } \\
\text { atividades que defendam a natureza. }\end{array}$ & & & & & & \\
\hline 22) É importante para ele nunca irritar alguém. & & & & & & \\
\hline $\begin{array}{l}\text { 23) É importante para ele ter suas próprias ideias } \\
\text { originais. }\end{array}$ & & & & & & \\
\hline $\begin{array}{l}\text { 24) É importante para ele proteger sua imagem } \\
\text { pública. }\end{array}$ & & & & & & \\
\hline
\end{tabular}




\begin{tabular}{|c|c|c|c|c|c|c|}
\hline & \multicolumn{6}{|c|}{ Quanto este rapaz se parece com você? } \\
\hline & $\begin{array}{c}\text { Não se } \\
\text { parece } \\
\text { nada } \\
\text { comigo }\end{array}$ & $\begin{array}{l}\text { Não se } \\
\text { parece } \\
\text { comigo }\end{array}$ & $\begin{array}{c}\text { Se } \\
\text { parece } \\
\text { pouco } \\
\text { comigo }\end{array}$ & $\begin{array}{c}\text { Se } \\
\text { parece } \\
\text { mais } \\
\text { ou } \\
\text { menos } \\
\text { comigo }\end{array}$ & $\begin{array}{c}\text { Se } \\
\text { parece } \\
\text { comigo }\end{array}$ & $\begin{array}{c}\text { Se } \\
\text { parece } \\
\text { muito } \\
\text { comigo }\end{array}$ \\
\hline $\begin{array}{l}\text { 25) É muito importante para ele ajudar as pessoas } \\
\text { que lhe são queridas. }\end{array}$ & & & & & & \\
\hline $\begin{array}{l}\text { 26) É importante para ele estar seguro } \\
\text { pessoalmente. }\end{array}$ & & & & & & \\
\hline $\begin{array}{l}\text { 27) É importante para ele ser um amigo confiável } \\
\text { e fiel. }\end{array}$ & & & & & & \\
\hline $\begin{array}{l}\text { 28) É importante para ele assumir riscos que } \\
\text { fazem a vida ficar excitante. }\end{array}$ & & & & & & \\
\hline $\begin{array}{l}\text { 29) É importante para ele ter poder para conseguir } \\
\text { com que as pessoas façam o que ele quer. }\end{array}$ & & & & & & \\
\hline $\begin{array}{l}\text { 30) É importante para ele planejar suas atividades } \\
\text { de forma independente. }\end{array}$ & & & & & & \\
\hline $\begin{array}{l}\text { 31) É importante para ele seguir as regras mesmo } \\
\text { se ninguém estiver olhando. }\end{array}$ & & & & & & \\
\hline 32) É importante para ele ter muito sucesso. & & & & & & \\
\hline $\begin{array}{l}\text { 33) É importante para ele seguir os costumes da } \\
\text { sua família ou os costumes de uma religião. }\end{array}$ & & & & & & \\
\hline $\begin{array}{l}\text { 34) É importante para ele ouvir e compreender as } \\
\text { pessoas que são diferentes dele. }\end{array}$ & & & & & & \\
\hline $\begin{array}{l}\text { 35) É importante para ele ter um Estado forte que } \\
\text { possa defender seus cidadãos. }\end{array}$ & & & & & & \\
\hline $\begin{array}{l}\text { 36) É importante para ele desfrutar dos prazeres } \\
\text { da vida. }\end{array}$ & & & & & & \\
\hline $\begin{array}{l}\text { 37) É importante para ele que todas as pessoas no } \\
\text { mundo tenham oportunidades iguais na vida. }\end{array}$ & & & & & & \\
\hline 38) É importante para ele ser humilde. & & & & & & \\
\hline $\begin{array}{l}\text { 39) É importante para ele expandir os seus } \\
\text { conhecimentos. }\end{array}$ & & & & & & \\
\hline $\begin{array}{l}\text { 40) É importante para ele honrar as práticas } \\
\text { tradicionais da sua cultura. }\end{array}$ & & & & & & \\
\hline $\begin{array}{l}\text { 41) É importante para ele ser a pessoa que diz aos } \\
\text { outros o que fazer. }\end{array}$ & & & & & & \\
\hline 42) É importante para ele obedecer todas as Leis. & & & & & & \\
\hline $\begin{array}{l}\text { 43) É importante para ele ter todos os tipos de } \\
\text { experiências novas. }\end{array}$ & & & & & & \\
\hline $\begin{array}{l}\text { 44) É importante para ele ter coisas caras que } \\
\text { mostram a sua riqueza. }\end{array}$ & & & & & & \\
\hline $\begin{array}{l}\text { 45) É importante para ele proteger o ambiente } \\
\text { natural da destruição ou poluição. }\end{array}$ & & & & & & \\
\hline $\begin{array}{l}\text { 46) É importante para ele aproveitar qualquer } \\
\text { oportunidade de se divertir. }\end{array}$ & & & & & & \\
\hline $\begin{array}{l}\text { 47) É importante para ele se preocupar com todas } \\
\text { as necessidades das suas pessoas queridas. }\end{array}$ & & & & & & \\
\hline $\begin{array}{l}\text { 48) É importante para ele que as pessoas } \\
\text { reconheçam o que ele alcança. }\end{array}$ & & & & & & \\
\hline 49) É importante para ele nunca ser humilhado. & & & & & & \\
\hline 50) É importante para ele que seu país se proteja & & & & & & \\
\hline
\end{tabular}




\begin{tabular}{|l|l|l|l|l|l|l|}
\hline & \multicolumn{3}{|c|}{ Quanto este rapaz se parece com você? } \\
\hline & $\begin{array}{c}\text { Não se } \\
\text { parece } \\
\text { nada } \\
\text { comigo }\end{array}$ & $\begin{array}{c}\text { Não se } \\
\text { parece } \\
\text { comigo }\end{array}$ & $\begin{array}{c}\text { Se } \\
\text { parece } \\
\text { pouco } \\
\text { comigo }\end{array}$ & $\begin{array}{c}\text { Se } \\
\text { parece } \\
\text { mais } \\
\text { ou } \\
\text { menos } \\
\text { comigo }\end{array}$ & $\begin{array}{c}\text { Se } \\
\text { parece } \\
\text { comigo }\end{array}$ & $\begin{array}{c}\text { Se } \\
\text { parece } \\
\text { muito } \\
\text { comigo }\end{array}$ \\
\hline de todas as ameaças. & & & & & & \\
\hline $\begin{array}{l}\text { 51) É importante para ele nunca deixar as outras } \\
\text { pessoas com raiva. }\end{array}$ & & & & & & \\
\hline $\begin{array}{l}\text { 52) É importante para ele que todos sejam tratados } \\
\text { com justiça, mesmo pessoas que ele não conhece. }\end{array}$ & & & & & & \\
\hline $\begin{array}{l}\text { 53) É importante para ele nunca fazer qualquer } \\
\text { coisa que seja perigosa. }\end{array}$ & & & & & & \\
\hline $\begin{array}{l}\text { 54) É importante para ele nunca buscar atenção ou } \\
\text { elogios públicos. }\end{array}$ & & & & & & \\
\hline $\begin{array}{l}\text { 55) É importante para ele que todos os seus } \\
\text { amigos e família possam acreditar nele } \\
\text { completamente. }\end{array}$ & & & & & & \\
\hline $\begin{array}{l}\text { 56) É importante para ele ser livre para escolher } \\
\text { por ele mesmo o que fazer. }\end{array}$ & & & & & & \\
\hline $\begin{array}{l}\text { 57) É importante para ele aceitar as pessoas, } \\
\text { mesmo quando ele discorda deles. }\end{array}$ & & & & & \\
\hline
\end{tabular}


Julgamento e significado: Abaixo você irá avaliar a maneira pela qual julga a compra de um automóvel, não existe resposta errada ou correta.

\begin{tabular}{|c|c|c|c|c|c|c|c|}
\hline \multirow[b]{2}{*}{ Sou racional ao comprar um carsem importância } & & & & \multicolumn{4}{|c|}{$\begin{array}{l}\text { Definitivamente } \\
\text { sim/ sempre }\end{array}$} \\
\hline & 1 & 2 & \multicolumn{5}{|c|}{3 MuAt } \\
\hline Escolho um carro que posso exibir com orgulho. & 1 & 2 & 3 & 4 & 5 & 6 & 7 \\
\hline $\begin{array}{l}\text { Escolho um carro compatível com o que penso sobre mim } \\
\text { mesmo. }\end{array}$ & 1 & 2 & 3 & 4 & 5 & 6 & 7 \\
\hline Escolho um carro que está na moda. & 1 & 2 & 3 & 4 & 5 & 6 & 7 \\
\hline $\begin{array}{l}\text { Escolho um carro sensorialmente agradável (ex: olfato, visão, } \\
\text { etc.). }\end{array}$ & 1 & 2 & 3 & 4 & 5 & 6 & 7 \\
\hline $\begin{array}{l}\text { Seleciono o carro que posso encontrar mais facilmente para } \\
\text { comprar. }\end{array}$ & 1 & 2 & 3 & 4 & 5 & 6 & 7 \\
\hline Escolho um carro reconhecidamente caro. & 1 & 2 & 3 & 4 & 5 & 6 & 7 \\
\hline Considero os prós e contras antes de comprar um carro. & 1 & 2 & 3 & 4 & 5 & 6 & 7 \\
\hline Escolho um carro que me deixe de bom humor ao usá-lo. & 1 & 2 & 3 & 4 & 5 & 6 & 7 \\
\hline Seleciono o carro de uso mais fácil. & 1 & 2 & 3 & 4 & 5 & 6 & 7 \\
\hline $\begin{array}{l}\text { Considero importante comprar uma marca de carro } \\
\text { reconhecida socialmente. }\end{array}$ & 1 & 2 & 3 & 4 & 5 & 6 & 7 \\
\hline Controlo minha impulsividade ao comprar um carro. & 1 & 2 & 3 & 4 & 5 & 6 & 7 \\
\hline Dou mais importância à beleza de um carro. & 1 & 2 & 3 & 4 & 5 & 6 & 7 \\
\hline Seleciono o carro de forma cuidadosa. & 1 & 2 & 3 & 4 & 5 & 6 & 7 \\
\hline $\begin{array}{l}\text { Prefiro um carro que demonstre poder sobre as outras } \\
\text { pessoas. }\end{array}$ & 1 & 2 & 3 & 4 & 5 & 6 & 7 \\
\hline Prefiro um carro que reflita meu jeito de ser. & 1 & 2 & 3 & 4 & 5 & 6 & 7 \\
\hline $\begin{array}{l}\text { Procuro o máximo de informações sobre o carro que vou } \\
\text { comprar. }\end{array}$ & 1 & 2 & 3 & 4 & 5 & 6 & 7 \\
\hline $\begin{array}{l}\text { Seleciono o carro em função do meu sentimento em relação a } \\
\text { ele. }\end{array}$ & 1 & 2 & 3 & 4 & 5 & 6 & 7 \\
\hline Seleciono o carro de uso mais rápido. & 1 & 2 & 3 & 4 & 5 & 6 & 7 \\
\hline Penso bem antes de comprar um carro. & 1 & 2 & 3 & 4 & 5 & 6 & 7 \\
\hline
\end{tabular}


A respeito da compra de um automóvel em geral por gentileza avalie os itens:

\begin{tabular}{|c|c|c|c|c|c|c|c|c|c|c|}
\hline Estilo & 1 & 2 & 3 & 4 & 5 & 6 & 7 & 8 & 9 & 10 \\
\hline Espaço Interno. & 1 & 2 & 3 & 4 & 5 & 6 & 7 & 8 & 9 & 10 \\
\hline Volante suave. & 1 & 2 & 3 & 4 & 5 & 6 & 7 & 8 & 9 & 10 \\
\hline Segurança. & 1 & 2 & 3 & 4 & 5 & 6 & 7 & 8 & 9 & 10 \\
\hline Acabamento. & 1 & 2 & 3 & 4 & 5 & 6 & 7 & 8 & 9 & 10 \\
\hline Prestígio do carro. & 1 & 2 & 3 & 4 & 5 & 6 & 7 & 8 & 9 & 10 \\
\hline Interior Luxuoso. & 1 & 2 & 3 & 4 & 5 & 6 & 7 & 8 & 9 & 10 \\
\hline Baixa emissão de poluentes. & 1 & 2 & 3 & 4 & 5 & 6 & 7 & 8 & 9 & 10 \\
\hline Motor grande. & 1 & 2 & 3 & 4 & 5 & 6 & 7 & 8 & 9 & 10 \\
\hline O carro ser grande. & 1 & 2 & 3 & 4 & 5 & 6 & 7 & 8 & 9 & 10 \\
\hline Barato. & 1 & 2 & 3 & 4 & 5 & 6 & 7 & 8 & 9 & 10 \\
\hline Fazer muitos quilómetros por litro. & 1 & 2 & 3 & 4 & 5 & 6 & 7 & 8 & 9 & 10 \\
\hline Ser capaz de atingir altas velocidades. & 1 & 2 & 3 & 4 & 5 & 6 & 7 & 8 & 9 & 10 \\
\hline Aquecimento interno. & 1 & 2 & 3 & 4 & 5 & 6 & 7 & 8 & 9 & 10 \\
\hline Comportamento em estradas. & 1 & 2 & 3 & 4 & 5 & 6 & 7 & 8 & 9 & 10 \\
\hline Manutenção baixa. & 1 & 2 & 3 & 4 & 5 & 6 & 7 & 8 & 9 & 10 \\
\hline Confiabilidade. & 1 & 2 & 3 & 4 & 5 & 6 & 7 & 8 & 9 & 10 \\
\hline Ser compacto. & 1 & 2 & 3 & 4 & 5 & 6 & 7 & 8 & 9 & 10 \\
\hline Ser confortável. & 1 & 2 & 3 & 4 & 5 & 6 & 7 & 8 & 9 & 10 \\
\hline Me importo com a cor. & 1 & 2 & 3 & 4 & 5 & 6 & 7 & 8 & 9 & 10 \\
\hline Ar condicionado (resfriamento) & 1 & 2 & 3 & 4 & 5 & 6 & 7 & 8 & 9 & 10 \\
\hline Engenharia interna do carro avançada & 1 & 2 & 3 & 4 & 5 & 6 & 7 & 8 & 9 & 10 \\
\hline
\end{tabular}




\begin{tabular}{|c|c|c|}
\hline \multicolumn{3}{|c|}{ Informações pessoais } \\
\hline $\begin{array}{l}\text { Sexo: } \\
\begin{array}{l}\text { 1. } \square \text { Masculino 2. } \square \text { Feminino }\end{array}\end{array}$ & $\begin{array}{l}\text { ANO de } \\
\text { nascimento: }\end{array}$ & Número de filhos: \\
\hline \multicolumn{3}{|c|}{$\begin{array}{l}\text { Considerando que a renda familiar média no DF é de R\$4.500,00 a sua renda familiar } \\
\text { (renda conjunta das pessoas que vivem no seu domicílio) é: } \\
\begin{array}{ll}\text { 1. } \square \text { Muito abaixo da média } & \text { 4. } \square \text { Acima da média } \\
\text { 2. } \square \text { Abaixo da média } & \text { 5. } \square \text { Muito acima da média } \\
\text { 3. } \square \text { Próximo à média } & \end{array}\end{array}$} \\
\hline $\begin{array}{l}\text { Escolarida de } \\
\text { 1. } \square \text { Primário } \\
\text { 2. } \square \text { Ensino médio } \\
\text { 3. } \square \text { Superior incompleto }\end{array}$ & $\begin{array}{l}\text { 4. } \square \text { Superior completo } \\
\text { 5. } \square \text { Especialização } \\
\text { 6. } \square \text { Mestrado/doutorado }\end{array}$ & $\begin{array}{l}\text { 54) Estado Civil } \\
\text { 1. } \square \text { Casado / Amigado } \\
\text { 2. } \square \text { Solteiro } \\
\text { 3. } \square \text { Divorciado / Separado } \\
\text { 4. } \square \text { Viúvo (a) }\end{array}$ \\
\hline
\end{tabular}

Você respondeu esse questionário anônimo de maneira honesta?

\begin{tabular}{|c|c|c|c|c|c|c|c|c|c|}
\hline 1 & 2 & 3 & 4 & 5 & 6 & 7 & 8 & 9 & 10 \\
\hline
\end{tabular}
Não fui muito honesto
Fui muito honesto


The following is a list of things that some people look for or want out of life. Sometimes you find that you have to give up a little of something important because something else is most important to you. Please study the list carefully and then rate each thing on how important it is in your daily life, where $1=$ important to me, and $9=$ extremely important to me

Most

Impt. to me Important to me

1. Sense of Belonging (to be accepted and needed by

your family, friends, and community) 1--2--3--4--5--6--7--8--9

2. Excitement (to experience stimulation and

thrills)

$1--2--3--4--5--6--7--8--9$

3. Warm Relationships with Others (to have close

companionships and intimate friendships) 1--2--3--4--5--6--7--8--9

4. Self-Fulfillment (to find peace of mind and to

make the best use of your talents)

$1--2--3--4--5--6--7--8--9$

5. Being Well-Respected (to be admired by

others and to receive recognition) 1--2--3--4--5--6--7--8--9

6. Fun and Enjoyment in Life (to lead a pleasurable, happy life)

$1--2--3--4--5--6--7--8--9$

7. Security (to be safe and protected from

misfortune and attack) $\quad$ 1--2--3--4--5--6--7--8--9

8. Self-Respect (to be proud of yourself and

confident with who you are) $\quad$ 1--2--3--4--5--6--7--8--9

9. A Sense of Accomplishment (to succeed at

what you want to do)

1--2--3---4--5--6--7--8-9 


\section{PVQ-R2 Male}

Here we briefly describe different people. Please read each description and think about how much that person is or

is not like you. Put an $\mathrm{X}$ in the box to the right that shows how much the person described is like you.

HOW MUCH LIKE YOU IS THIS PERSON?

\begin{tabular}{ccccc} 
Not like & \multicolumn{2}{c}{ Moder- } & & Very \\
me at & Not like A little & ately & Like & much \\
all & me like me like me & me & like me
\end{tabular}

1. It is important to him to form his own understanding of things

2. It is important to him that there is stability and order in the wider society .

3. It is important to him to have a good time.

4. It is important to him to avoid upsetting other people.

5. It is important to him to protect the weak and vulnerable people in society.

6. It is important to him that people do what he says they should.

7. It is important to him never to be boastful or self-important.

8. It is important to him to care for nature.

9. It is important to him that no one should ever shame him.

10. It is important to him always to look for different things to do.

11. It is important to him to take care of people he is close to.

12. It is important to him to have the power that money can bring..

13. It is very important to him to avoid disease and protect his health.

14. It is important to him to be tolerant toward all kinds of people and groups.

15. It is important to him never to violate rules or regulations.

16. It is important to him to make his own decisions about his life.

17. It is important to him to have ambitions in life.

18. It is important to him to maintain traditional values and ways of thinking.

19. It is important to him that people he knows have full confidence in him. 


$\begin{array}{ccccc}\text { Not like } & & \text { Moder- } & & \text { Very } \\ \text { me at } & \text { Not like A little } & \text { ately } & \text { Like } & \text { much } \\ \text { all } & \text { me like me like me } & \text { me } & \text { like me }\end{array}$

20. It is important to him to be wealthy.

21. It is important to him to take part in activities to defend nature.

22. It is important to him never to annoy anyone.

23. It is important to him to have his own original ideas.

24. It is important to him to protect his public image.

25. It is very important to him to help the people dear to him.

26. It is important to him to be personally safe and secure.

27. It is important to him to be a dependable and trustworthy friend.

28. It is important to him to take risks that make life exciting.

29. It is important to him to have the power to make people do what he wants..

30. It is important to him to plan his activities independently.

31. It is important to him to follow rules even when no-one is watching.

32. It is important to him to be very successful.

33. It is important to him to follow his family's customs or the customs of a religion.

34. It is important to him to listen to and understand people who are different from him.

35. It is important to him to have a strong state that can defend its citizens.

36. It is important to him to enjoy life's pleasures.

37. It is important to him that every person in the world have equal opportunities in life.

38. It is important to him to be humble.

39. It is important to him to expand his knowledge.

40. It is important to him to honor the traditional practices of his culture.

41. It is important to him to be the one who tells others what to do..

42. It is important to him to obey all the laws.

43. It is important to him to have all sorts of new experiences..

44. It is important to him to own expensive things that show his wealth 


$\begin{array}{ccccc}\text { Not like } & & \text { Moder- } & & \text { Very } \\ \text { me at } & \text { Not like A little } & \text { ately } & \text { Like } & \text { much } \\ \text { all } & \text { me like me like me } & \text { me } & \text { like me }\end{array}$

45. It is important to him to protect the natural environment from destruction or pollution.

46. It is important to him to take advantage of every opportunity to have fun.

47. It is important to him to concern himself with every need of his dear ones.

48. It is important to him that people recognize what he achieves.

49. It is important to him never to be humiliated.

50. It is important to him that his country protect itself against all threats.

51. It is important to him never to make other people angry.

52. It is important to him that everyone be treated justly, even people he doesn't know.

53. It is important to him never to do anything dangerous.

54. It is important to him never to seek public attention or praise.

55. It is important to him that all his friends and family can rely on him completely.

56. It is important to him to be free to choose what he does by himself.

57. It is important to him to accept people even when he disagrees with them. 


\title{
PVQ-R2 Female
}

Here we briefly describe different people. Please read each description and think about how much that person is or

is not like you. Put an $X$ in the box to the right that shows how much the person described is like you.

\author{
HOW MUCH LIKE YOU IS \\ THIS PERSON? \\ Not like

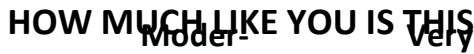 \\ me at Not like A little dtERSON?ke much \\ all me like me like me me like me
}

1. It is important to him to develop her own understanding of things.

2. It is important to her that there is stability and order in the wider society .

3. It is important to her to have a good time.

4. It is important to her to avoid upsetting other people.

5. It is important to her to protect the weak and vulnerable people in society.

6. It is important to her that people do what she says they should.

7. It is important to her never to be boastful or self-important.

8. It is important to her to care for nature.

9. It is important to her that no one should ever shame her.

10. It is important to her always to look for different things to do.

11. It is important to her to take care of people she is close to.

12. It is important to her to have the power that money can bring.

13. It is very important to her to avoid disease and protect her health.

14. It is important to her to be tolerant toward all kinds of people and groups.

15. It is important to her never to violate rules or regulations.

16. It is important to her to make her own decisions about her life.

17. It is important to her to have ambitions in life.

18. It is important to her to maintain traditional values and ways of thinking.

19. It is important to her that people she knows have full confidence in her. 


$\begin{array}{ccccc}\text { Not like } & & \text { Moder- } & & \text { Very } \\ \text { me at } & \text { Not like A little } & \text { ately } & \text { Like } & \text { much } \\ \text { all } & \text { me like me like me } & \text { me } & \text { like me }\end{array}$

20. It is important to her to be wealthy.

21. It is important to her to take part in activities to defend nature.

22. It is important to her never to annoy anyone.

23. It is important to her to have her own original ideas.

24. It is important to her to protect her public image.

25. It is very important to her to help the people dear to her.

26. It is important to her to be personally safe and secure.

27. It is important to her to be a dependable and trustworthy friend.

28. It is important to her to take risks that make life exciting.

29. It is important to her to have the power to make people do what she wants..

30. It is important to him to plan her activities independently.

31. It is important to her to follow rules even when no-one is watching.

32. It is important to her to be very successful.

33. It is important to her to follow her family's customs or the customs of a religion.

34. It is important to her to listen to and understand people who are different from her.

35. It is important to her to have a strong state that can defend its citizens.

36. It is important to her to enjoy life's pleasures.

37. It is important to her that every person in the world have equal opportunities in life.

38. It is important to her to be humble.

39. It is important to her to expand her knowledge.

40. It is important to her to honor the traditional practices of her culture.

41. It is important to her to be the one who tells others what to do..

42. It is important to her to obey all the laws.

43. It is important to her to have all sorts of new experiences..

44. It is important to her to own expensive things that show her wealth 


\begin{tabular}{ccccc} 
Not like & \multicolumn{1}{c}{ Moder- } & & Very \\
me at & Not like A little & ately & Like & much \\
all & me like me like me & me & like me
\end{tabular}

45. It is important to her to protect the natural environment from destruction or pollution.

46. It is important to her to take advantage of every opportunity to have fun.

47. It is important to her to concern herself with every need of her dear ones.

48. It is important to her that people recognize what she achieves.

49. It is important to her never to be humiliated.

50. It is important to her that her country protect itself against all threats.

51. It is important to her never to make other people angry.

52. It is important to her that everyone be treated justly, even people she doesn't know.

53. It is important to her never to do anything dangerous.

54. It is important to her never to seek public attention or praise.

55. It is important to her that all her friends and family can rely on her completely.

56. It is important to her to be free to choose what she does by herself..

57. It is important to her to accept people even when she disagrees with them. 


\begin{tabular}{|c|c|c|c|c|c|c|c|c|c|}
\hline I am rational when buying an automobile & 1 & 2 & 3 & 4 & 5 & 6 & 7 & 8 & 9 \\
\hline I choose an automobile that I can proudly display. & 1 & 2 & 3 & 4 & 5 & 6 & 7 & 8 & 9 \\
\hline $\begin{array}{l}\text { I choose an automobile that is compatible with what I } \\
\text { think about myself. }\end{array}$ & 1 & 2 & 3 & 4 & 5 & 6 & 7 & 8 & 9 \\
\hline I choose an automobile that is fashionable. & 1 & 2 & 3 & 4 & 5 & 6 & 7 & 8 & 9 \\
\hline $\begin{array}{l}\text { I choose an automobile that is pleasant for the senses } \\
\text { (i.e. smell, sight, etc.). }\end{array}$ & 1 & 2 & 3 & 4 & 5 & 6 & 7 & 8 & 9 \\
\hline $\begin{array}{l}\text { I select an automobile that I can easily find to } \\
\text { purchase. }\end{array}$ & 1 & 2 & 3 & 4 & 5 & 6 & 7 & 8 & 9 \\
\hline $\begin{array}{l}\text { I choose an automobile that is recognizable } \\
\text { expensive. }\end{array}$ & 1 & 2 & 3 & 4 & 5 & 6 & 7 & 8 & 9 \\
\hline $\begin{array}{l}\text { I consider the pros and cons before buying an } \\
\text { automobile. }\end{array}$ & 1 & 2 & 3 & 4 & 5 & 6 & 7 & 8 & 9 \\
\hline $\begin{array}{l}\text { I choose an automobile that makes me in a good } \\
\text { mood when I am using it. }\end{array}$ & 1 & 2 & 3 & 4 & 5 & 6 & 7 & 8 & 9 \\
\hline I select an automobile of easier use. & 1 & 2 & 3 & 4 & 5 & 6 & 7 & 8 & 9 \\
\hline $\begin{array}{l}\text { I choose an automobile that makes me in a good } \\
\text { mood when I am using it. }\end{array}$ & 1 & 2 & 3 & 4 & 5 & 6 & 7 & 8 & 9 \\
\hline $\begin{array}{l}\text { I consider being important to buy a brand of } \\
\text { automobile that is socially recognized. }\end{array}$ & 1 & 2 & 3 & 4 & 5 & 6 & 7 & 8 & 9 \\
\hline $\begin{array}{l}\text { I control my impulsivity when I am buying an } \\
\text { automobile. }\end{array}$ & 1 & 2 & 3 & 4 & 5 & 6 & 7 & 8 & 9 \\
\hline I give more importance to the automobile's beauty. & 1 & 2 & 3 & 4 & 5 & 6 & 7 & 8 & 9 \\
\hline I select my automobile in a careful way. & 1 & 2 & 3 & 4 & 5 & 6 & 7 & 8 & 9 \\
\hline $\begin{array}{l}\text { I prefer an automobile that demonstrates power over } \\
\text { people. }\end{array}$ & 1 & 2 & 3 & 4 & 5 & 6 & 7 & 8 & 9 \\
\hline I prefer an automobile that reflects the way I am. & 1 & 2 & 3 & 4 & 5 & 6 & 7 & 8 & 9 \\
\hline $\begin{array}{l}\text { I search the maximum information about the } \\
\text { automobile I will buy. }\end{array}$ & 1 & 2 & 3 & 4 & 5 & 6 & 7 & 8 & 9 \\
\hline $\begin{array}{l}\text { I select an automobile in function of my feeling } \\
\text { towards it. }\end{array}$ & 1 & 2 & 3 & 4 & 5 & 6 & 7 & 8 & 9 \\
\hline
\end{tabular}


Thinking about automobiles in general, please rate how important each of the following characteristics are to you when deciding on a possible automobile purchase.

Please use a scale of 0 to 10 , with 0 meaning it is "not at all important" up to 10 , meaning it is "very important".

\begin{tabular}{|c|c|c|c|c|c|c|c|c|c|c|c|}
\hline & $\begin{array}{l}\text { Not at all } \\
\text { important }\end{array}$ & & & & & & & & & & $\begin{array}{l}\text { Very } \\
\text { Important }\end{array}$ \\
\hline Style & O & O & O & O & O & O & O & $\mathrm{O}$ & O & O & 0 \\
\hline Spacious interior & $\mathrm{O}$ & 0 & $\mathrm{O}$ & 0 & $\mathrm{O}$ & 0 & $\mathrm{O}$ & $\mathrm{O}$ & $\mathrm{O}$ & 0 & $\mathrm{O}$ \\
\hline Smooth riding & O & 0 & O & O & O & O & O & O & O & O & $\bigcirc$ \\
\hline Safety & $\mathrm{O}$ & $\mathrm{O}$ & $\mathrm{O}$ & $\mathrm{O}$ & $\mathrm{O}$ & $\mathrm{O}$ & $\mathrm{O}$ & $\mathrm{O}$ & $\mathrm{O}$ & $\mathrm{O}$ & $\mathrm{O}$ \\
\hline Quality workmanship & O & O & O & O & O & O & O & & O & O & O \\
\hline Prestigious & $\mathrm{O}$ & $\mathrm{O}$ & O & $\mathrm{O}$ & O & $\mathrm{O}$ & O & $\mathrm{O}$ & $\mathrm{O}$ & O & $\mathrm{O}$ \\
\hline Luxurious interior & O & O & O & O & O & O & O & & O & O & \\
\hline Low pollution emission & $\mathrm{O}$ & $\mathrm{O}$ & $\mathrm{O}$ & $\mathrm{O}$ & $\mathrm{O}$ & $\mathrm{O}$ & $\mathrm{O}$ & $\mathrm{O}$ & $\mathrm{O}$ & $\mathrm{O}$ & 0 \\
\hline Large engine & O & O & ○ & ○ & ○ & & O & & O & O & \\
\hline Large body size & $\mathrm{O}$ & 0 & $\mathrm{O}$ & $\mathrm{O}$ & $\mathrm{O}$ & $\mathrm{O}$ & $\mathrm{O}$ & O & $\mathrm{O}$ & $\mathrm{O}$ & $\mathrm{O}$ \\
\hline Inexpensive & O & O & ○ & O & $\bigcirc$ & O & O & & & & \\
\hline $\begin{array}{l}\text { High gas } \\
\text { mileage/kilometres per } \\
\text { litre }\end{array}$ & $\mathrm{O}$ & $\mathrm{O}$ & $\mathrm{O}$ & $\mathrm{O}$ & $\mathrm{O}$ & $\mathrm{O}$ & O & $\mathrm{O}$ & $\mathrm{O}$ & $\mathrm{O}$ & $\mathrm{O}$ \\
\hline $\begin{array}{l}\text { High speed } \\
\text { capabilities }\end{array}$ & O & C & C & 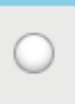 & & & & & & & \\
\hline Heating & 0 & $\mathrm{O}$ & $\mathrm{O}$ & $\mathrm{O}$ & $\mathrm{O}$ & $\mathrm{O}$ & $\mathrm{O}$ & $\mathrm{O}$ & $\mathrm{O}$ & $\mathrm{O}$ & O \\
\hline Road handling & 0 & O & O & $\bigcirc$ & O & O & O & O & O & O & O \\
\hline $\begin{array}{l}\text { Few repairs } \\
\text { needed/low } \\
\text { maintenance }\end{array}$ & $\mathrm{O}$ & $\mathrm{O}$ & $\mathrm{O}$ & $\mathrm{O}$ & $\mathrm{O}$ & 0 & $\mathrm{O}$ & $\mathrm{O}$ & $\mathrm{O}$ & $\mathrm{O}$ & $\mathrm{O}$ \\
\hline Reliability & $\bigcirc$ & $\bigcirc$ & O & O & O & O & O & O & O & O & $\bigcirc$ \\
\hline Compact & 0 & $\mathrm{O}$ & $\mathrm{O}$ & $\mathrm{O}$ & $\mathrm{O}$ & $\mathrm{O}$ & $\mathrm{O}$ & $\mathrm{O}$ & $\mathrm{O}$ & O & $\mathrm{O}$ \\
\hline Comfort & $\bigcirc$ & $\bigcirc$ & O & $\bigcirc$ & 0 & O & ○ & O & O & O & $\bigcirc$ \\
\hline \multirow{2}{*}{$\begin{array}{l}\text { Colour } \\
\text { Air conditioning } \\
\text { (cooling) }\end{array}$} & $\mathrm{O}$ & O & $\mathrm{O}$ & $\mathrm{O}$ & $\mathrm{O}$ & $\mathrm{O}$ & $\mathrm{O}$ & $\mathrm{O}$ & $\mathrm{O}$ & $\mathrm{O}$ & $\mathrm{O}$ \\
\hline & $\bigcirc$ & & & & & & & & & & \\
\hline Advanced engineering & 0 & 0 & $\mathrm{O}$ & 0 & $\mathrm{O}$ & $\mathrm{O}$ & $\mathrm{O}$ & $\mathrm{O}$ & $\mathrm{O}$ & $\mathrm{O}$ & $\mathrm{O}$ \\
\hline
\end{tabular}




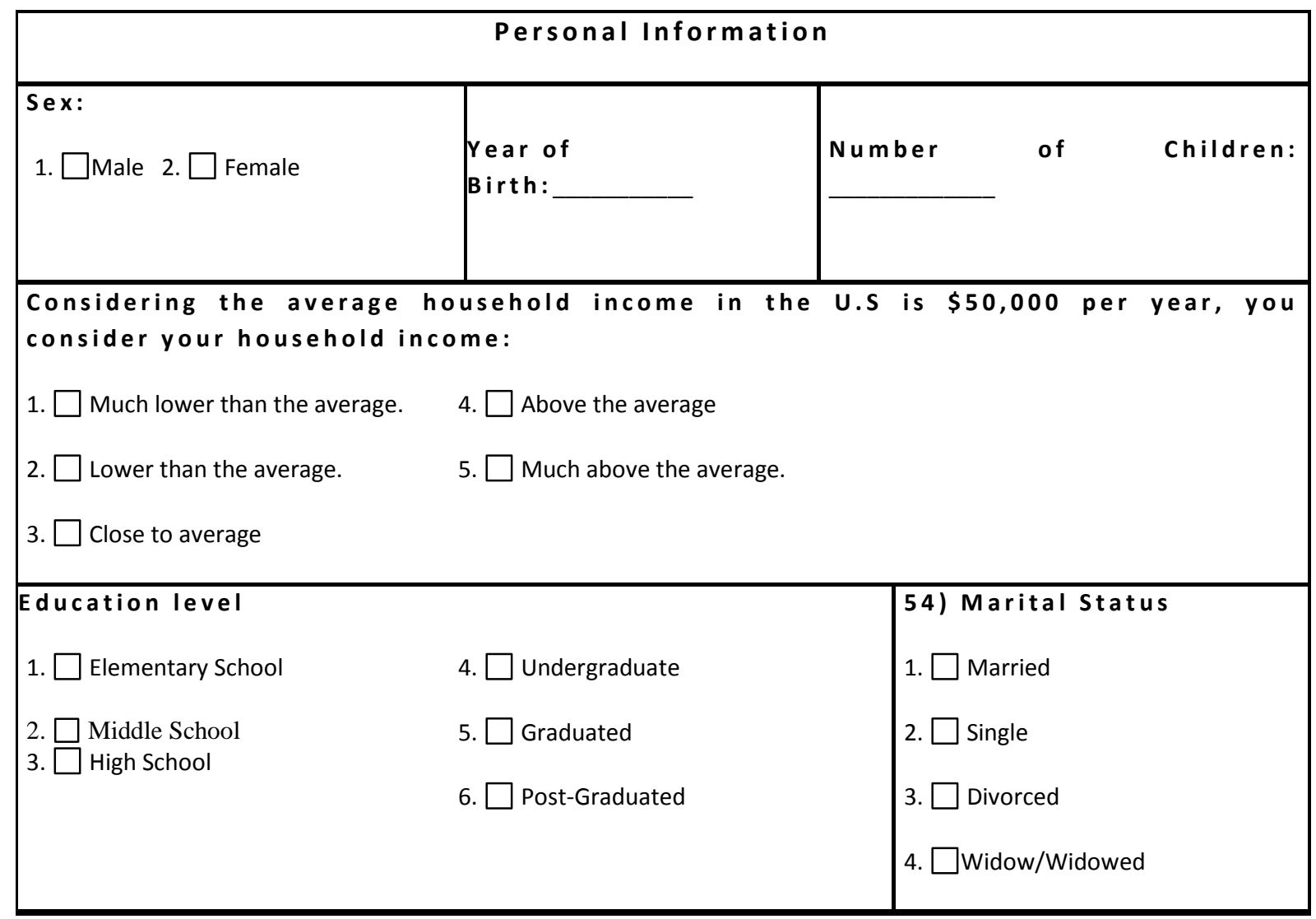

